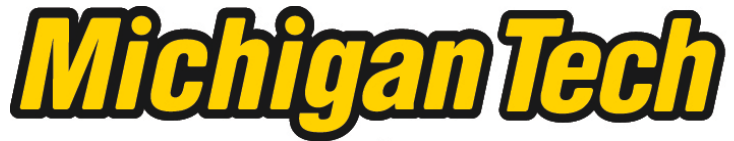 \\ Michigan Technological University Create the Future Digital Commons @ Michigan Tech
}

Reflection, refraction, and rejection : copper smelting heritage and the execution of environmental policy

Bode J. Morin

Michigan Technological University

Follow this and additional works at: https://digitalcommons.mtu.edu/etds

Part of the Archaeological Anthropology Commons

Copyright 2009 Bode J. Morin

\section{Recommended Citation}

Morin, Bode J., "Reflection, refraction, and rejection : copper smelting heritage and the execution of environmental policy", Dissertation, Michigan Technological University, 2009.

https://doi.org/10.37099/mtu.dc.etds/304

Follow this and additional works at: https://digitalcommons.mtu.edu/etds

Part of the Archaeological Anthropology Commons 


\title{
REFLECTION, REFRACTION, AND REJECTION: COPPER SMELTING HERITAGE AND THE EXECUTION OF ENVIRONMENTAL POLICY
}

\author{
By
}

Bode J. Morin

\author{
A DISSERTATION \\ Submitted in partial fulfillment of the requirements \\ for the degree of \\ DOCTOR OF PHILOSOPHY \\ Industrial Heritage and Archeology
}

MICHIGAN TECHNOLOGICAL UNIVERSITY

2009

Copyright (C) Bode J. Morin 2009 

This dissertation, "Reflection, Refraction, and Rejection: Copper Smelting Heritage and the Execution of Environmental Policy," is hereby approved in partial fulfillment of the requirements for the degree of DOCTOR OF PHILOSOPHY in the field of Industrial Heritage and Archeology.

\section{SOCIAL SCIENCES DEPARTMENT}

\section{Signatures:}

Dissertation Advisor:

Terry Reynolds

Committee:

Susan Martin

Patrick Martin

Stan Vitton

Department Chair:

Patrick Martin

Date: 



\section{Acknowledgements}

It is of course impossible to acknowledge everyone who helped, encouraged, or supported this project, but several key people and institutions deserve recognition and thanks, especially the archives, repositories, and museum collections that supplied the research data for this dissertation. The Ducktown Basin Museum and its director, Ken

Rush, provided valuable local heritage insights, information, documents, and photographs of the Tennessee Copper industry. Ellen Crain and Lee Whitney of the Butte-Silver Bow Archives provided key direction and access to their Montana collections, important contacts in the state, and valuable insights into their community. The Michigan Technological University Archives and Copper Country Historical Collection archivists Erik Nordberg and Julie Blair provided guided access into the MTU collections, and key insights and nuanced discussions about regional mining and tourism history. Several libraries and institutions maintained regional Superfund public repositories including the Ducktown, Tennessee, City Hall, the Montana Tech Library in Butte, Montana, and the Portage Lake Public Library in Houghton, Michigan. Helpful federal document collections included the EPA Montana Superfund office in Helena, Montana, the EPA Region 8 library in Denver, and the National Park Service Technical Information Center in Denver.

I would also like to thank Sara Sparks of the EPA in Butte, Brian Shovers of the Montana State Library, Lori Hallauer of the EPA office in Helena, Jim Corless of Keweenaw National Historical Park, Fred Quivik of Philadelphia, Pennsylvania, Paul White now of Anchorage, Alaska, and John Sesso and Chuck Carrig of Butte-Silver Bow 
County for their helpful direction and insights. Unfortunately, university rules forbid me from mentioning people who provided information, opinion, and data during oral interviews, but for those of you I talked with in Tennessee and Montana, and refer to as "Relevant Authorities" in the text, I thank you.

Michigan Technological University and the Social Sciences Department were, and are, dedicated to the success of their students and many of them deserve thanks. Karen Aho and Gina Stevens made any administrative forays inside and outside of the department painless and successful. Bruce Seely, as department-head for three of my four $\mathrm{PhD}$ years then dean of Sciences and Arts, encouraged and supported the pursuit of this new $\mathrm{PhD}$ at each level. Larry Lankton was always open for a chat about local mining history issues and provided pre-publication access to his latest book, and Carol McLennan sat on my exam committee and shared, encouraged, and directed my interests in the after-effects of mining. Stan Vitton of the Civil and Environmental Engineering department sat on my dissertation committee and provided useful insights from an engineering, and extra-departmental perspective. Patrick Martin, as chair of the Industrial Archeology graduate program, Social Sciences department-head for my last year, secretary of the Society for Industrial Archeology, and member of my dissertation committee, supported and encouraged academic pursuits at every level, provided important guidance and insights into the field and practice of industrial archeology, and found and sometimes created, fundable projects and work. Susan Martin, who sat on both my masters (1995) and PhD committees encouraged and supported my work at every graduate level and always provided new, meaningful, and stimulating insights into 
whatever project I had questions or doubts about. Terry Reynolds as advisor and chair of both my masters and $\mathrm{PhD}$ graduate committees provided meaningful guidance for researching and writing large and small historical works, was always available to discuss research direction, thesis complications, funding options, and writing style, and was always supportive of departmental goals and activities.

I would also like to thank the Americana Foundation for their financial support for this dissertation, the National Science Foundation for financial support and dissertation travel support, the Michigan Technological University Graduate School for financial and tuition support, and the Social Sciences Department for financial, administrative, travel, and tuition support.

Lastly, I'd like to thank my family, especially my parents Pat and Glen Morin, for their encouragement and support, and Deborah Haddrill for her enduring patience, encouragement, and good humor over the four years I was away. 


\begin{abstract}
REFLECTION, REFRACTION, AND REJECTION: COPPER SMELTING HERITAGE AND THE EXECUTION OF ENVIRONMENTAL POLICY Bode J. Morin
\end{abstract}

This dissertation examines the global technological and environmental history of copper smelting and the conflict that developed between historic preservation and environmental remediation at major copper smelting sites in the United States after their productive periods ended. Part I of the dissertation is a synthetic overview of the history of copper smelting and its environmental impact. After reviewing the basic metallurgy of copper ores, the dissertation contains successive chapters on the history of copper smelting to 1640, culminating in the so-called German, or Continental, processing system; on the emergence of the rival Welsh system during the British industrial revolution; and on the growth of American dominance in copper production the late $19^{\text {th }}$ and early 20th centuries. The latter chapter focuses, in particular, on three of the most important early American copper districts: Michigan's Keweenaw Peninsula, Tennessee's Copper Basin, and Butte-Anaconda, Montana. As these three districts went into decline and ultimately out of production, they left a rich industrial heritage and significant waste and pollution problems generated by increasingly more sophisticated technologies capable of commercially processing steadily growing volumes of decreasingly rich ores.

Part II of the dissertation looks at the conflict between historic preservation and environmental remediation that emerged locally and nationally in copper districts as they went into decline and eventually ceased production. Locally, former copper mining communities often split between those who wished to commemorate a region's past importance and develop heritage tourism, and local developers who wished to clear up and clean out old industrial sites for other purposes. Nationally, Congress passed laws in the 1960s and 1970s mandating the preservation of historical resources (National Historic Preservation Act) and laws mandating the cleanup of contaminated landscapes (CERCLA, or Superfund), objectives sometimes in conflict - especially in the case of copper smelting sites. The dissertation devotes individual chapters to the conflicts that developed between environmental remediation, particularly involving the Environmental Protection Agency and the heritage movement in the Tennessee, Montana, and Michigan copper districts. A concluding chapter provides a broad model to illustrate the relationship between industrial decline, federal environmental remediation activities, and the growth of heritage consciousness in former copper mining and smelting areas, analyzes why the outcome varied in the three areas, and suggests methods for dealing with heritage-remediation issues to minimize conflict and maximize heritage preservation. 


\section{TABLE OF CONTENTS}

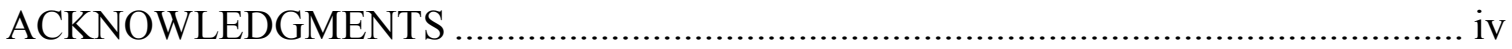

ABSTRACT



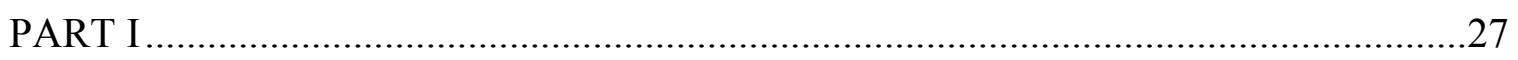

CHAPTER 1. THE BASICS OF COPPER AND SMELTING …………......................29

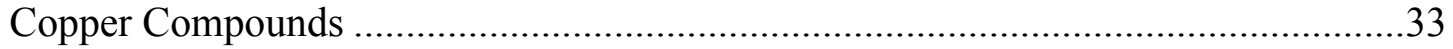

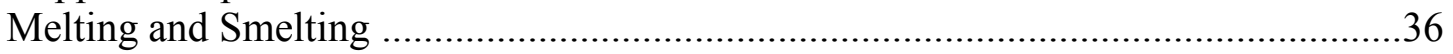

CHAPTER 2. A SHORT HISTORY OF COPPER SMELTING THROUGH 1640 .......45

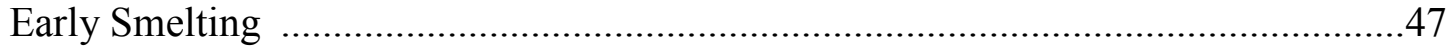

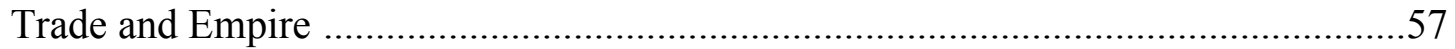

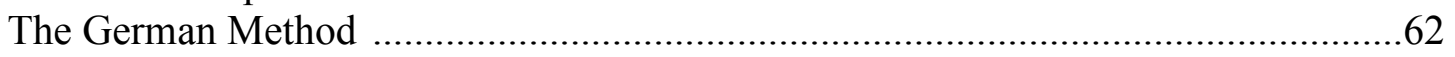

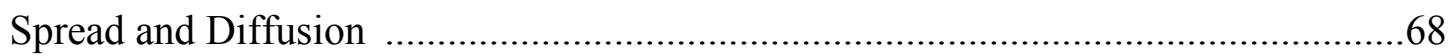

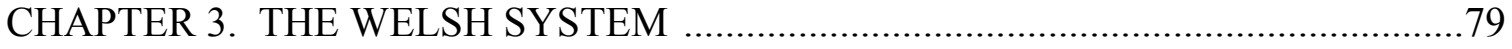



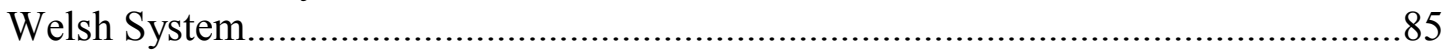

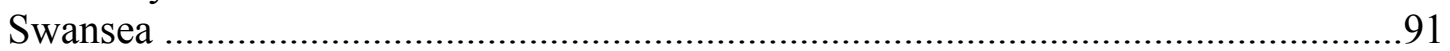

Welsh System Smelting ......................................................................................95

Effects of Copper Smelting in Swansea ……….................................................102

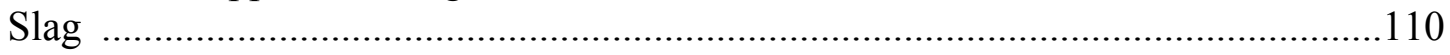

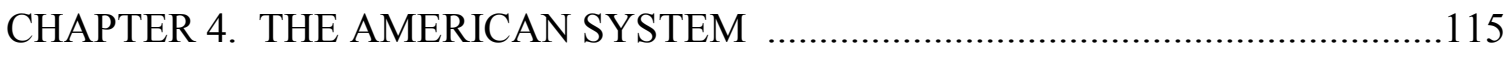

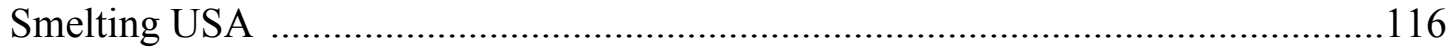

Michigan Smelting with Simplified Welsh Technologies ......................................128

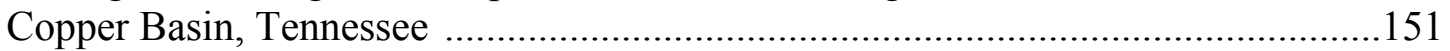

Montana-Richest Hill and Biggest Smelter on Earth ...............................................170



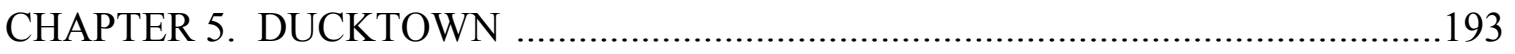

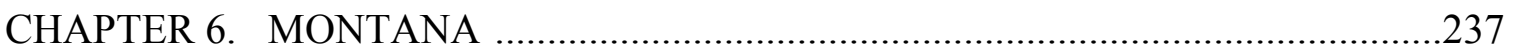

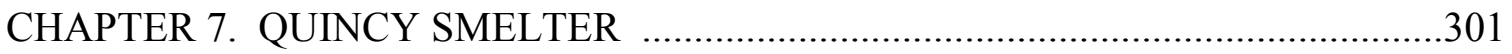

CHAPTER 8. CONCLUSION AND MINING DISTRICT HERITAGE MODEL .......341 


\section{LIST OF TABLES}



Table 3.1 Growth of Copper Smelter Industry in Swansea (1717-1928) ....................94

Table 3.2 Ore Classification System used in Swansea in the 1850s...........................97

Table 4.1 Michigan Copper Production ............................................................135

Table 4.2 Michigan-Copper Smelters 1844-1971 .................................................138

Table 6.1 List of Superfund Operable Units in Butte and Anaconda .......................275

Table 6.2 Timeline of Preservation and Remediation Events in Montana ................281



\section{LIST OF ILLUSTRATIONS}

Figure 1.1 Typical Sulfide Deposit. Ergani Maden, Turkey.........................................38

Figure 2.1 Early smelter demonstrating skin-bag bellows...........................................53

Figure 2.2 Side view of "New Kingdom" era smelter .................................................54

Figure 2.3 Comparison between a Bronze Age plano-concave and ox-hide ingot......54

Figure 2.4 Typical late Bronze Age and Roman era smelting furnace.........................55

Figure 2.5 German multiple-bin ore roasting ca. 1550 ..............................................64

Figure 2.6 German smelting ca. 1550s. ………………....................................65



Figure 2.8 German Copper Smelting Process ca. 1550 …………………..................69

Figure 3.1 Typical Reverberatory Furnace Arrangement ……………….....................81

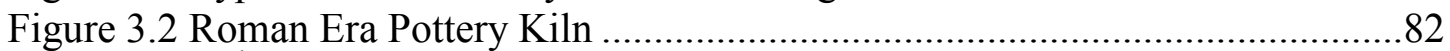



Figure 3.4 Location of British and Welsh Coal and Copper Deposits...........................86

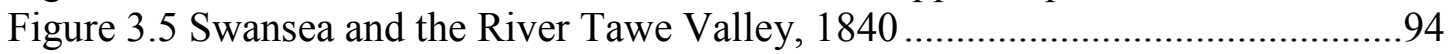

Figure 3.6 Typical Welsh calcining and melting reverberatory furnaces .....................96

Figure 3.7 Welsh Copper Smelting Process ca. 1850 …………………..................102

Figure 3.8 Swansea ca. 1860 ……………………….......................................103

Figure 4.1 United States Copper Production and Consumption 1880-1933 ..............122

Figure 4.2 Three blast furnace types used in the United States .................................124

Figure 4.3 The evolution of the reverberatory furnace, 1800-1924..........................127

Figure 4.4 Michigan's Keweenaw Peninsula Copper Country...................................129

Figure 4.5 Michigan Removable-Top Furnace ........................................................132

Figure 4.6 Native Copper Smelting Practice on the Keweenaw ca. 1910 .................142

Figure 4.7 Tennessee Copper Basin...................................................................152

Figure 4.8 Tennessee Copper Smelting Practice …………....................................156

Figure 4.9 Open heap roasting in the Ducktown District, ca. 1900 ............................160

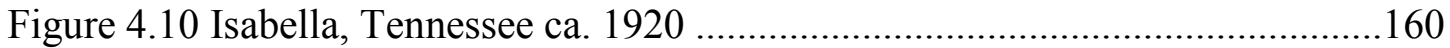

Figure 4.11 Tennessee Copper Company Chamber Acid Plant ………………….....166

Figure 4.12 Chamber Acid Process Figure .............................................................166

Figure 4.13 Butte-Anaconda Copper District Montana .............................................172 
Figure 4.14 Anaconda Upper Works Smelter with Lower Works ca. 1895 ..............175

Figure 4.15 Upright 12'-wide Bessemer Converters of the Washoe Smelter............179

Figure 4.16 Anaconda Washoe Smelter ca. 1950s ..................................................183

Figure 4.17 Diagram of Washoe Smelter, ca. 1950 ...............................................184

Figure 4.18 Montana Smelting Practices, ca. 1905 ................................................185

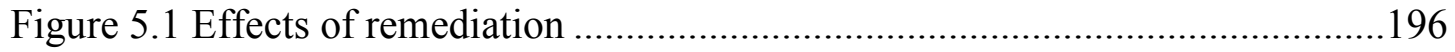

Figure 5.2 Map of Copper Basin Heritage and Remediation Sites...........................196

Figure 5.3 Conservation Rally in Copperhill, Tennessee, 1950 .............................209

Figure 5.4 The 30 acre parcel behind the Ducktown Basin ....................................212

Figure 5.5 Copper Basin Mining District .........................................................22

Figure 5.6 Fine Ore Bins at the London Mill....................................................22

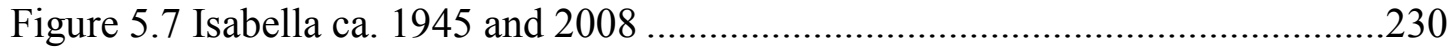

Figure 5.8 Copperhill smelter and acid plant......................................................231

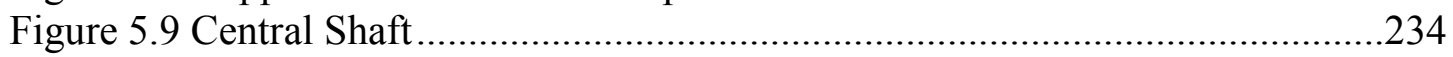

Figure 6.1 Anaconda Smelter Stack...................................................................238

Figure 6.2 Gallows Frames ..........................................................................240

Figure 6.3 Map of Butte-Anaconda Heritage and Remediation Sites .....................243

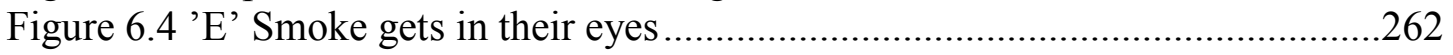

Figure 6.5 Extent of the expected Berkeley Pit expansion from 1970s to 2000.......267

Figure 6.6 Slag walls of the Butte Reduction Works..............................................289

Figure 6.7 Oldworks Golf Course.........................................................................293

Figure 6.8 Interpretive panels at the Anaconda Smelter Stack State Park................297

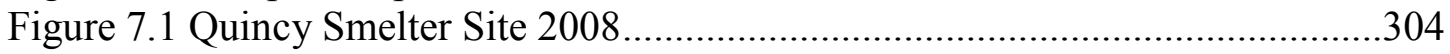

Figure 7.2 Map of Keweenaw Heritage and Remediation Sites ...............................304

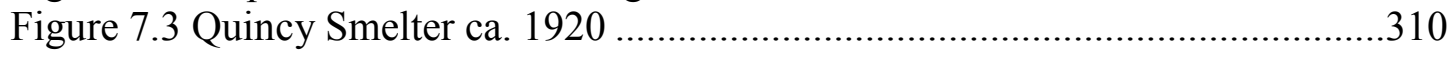

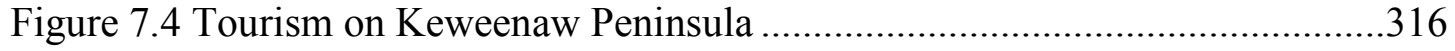

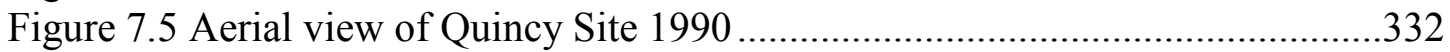

Figure 7.6 Quincy Smelter Base map for proposed final remediation, 2009 ............339

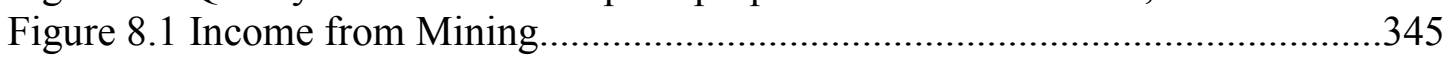

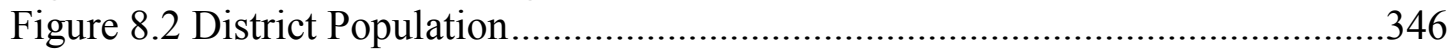

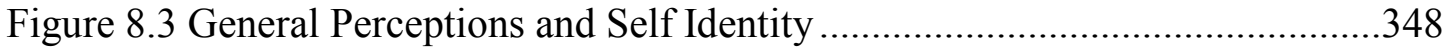

Figure 8.4 Environmental Degradation Concern .................................................350

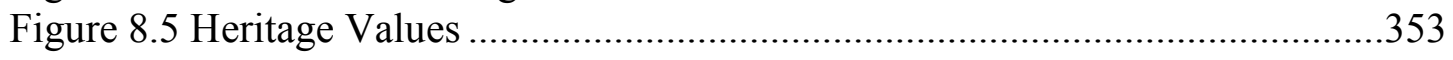




\section{INTRODUCTION}

Essential for social identity and collective purpose, heritage enriches us through remembered precursors and prospective heirs. But these enduring benefits blind us to a mounting backlash. Age-old aversion toward husbanding the past today grows more virulent. Nature conservation arouses similar hostility, but animus against heritage is harder to counter. Environmentalists can threaten global extinction; heritage advocates warn merely of lower quality of life. To many that seems a lesser, even a negligible threat.

-David Lowenthal, 2000 ("Stewarding the Past in a Perplexing Present" in Values and Heritage Conservation, 18)

In its simplest form, this is a heritage dissertation. It examines the debates over which things a community should save, how the final decisions are influenced and negotiated, and what, if anything, should ultimately be remembered about the past. These are not, however, simple or uncontested questions because the significance of past events and historical materials are not accepted equally. This dissertation uses a specific genre, industrial heritage, and the complicated perceptions of value in an often disheveled and blighted landscape to explore these questions. Industrial heritage poses challenges other types of heritage do not. In terms of merely preserving industrial structures, complications of process-interpretation and structural-deterioration exist in forms and scales that simply do not affect historic house museums or living-history farms. Further, industrial sites can encompass entire landscapes and, because of increasingly complex and historically significant operations in the late $19^{\text {th }}$ and early $20^{\text {th }}$ centuries, often include some hazard or hazardous waste threat to human health or the environment. Both of these situations tend to complicate the industrial setting leaving a tangled legacy in 
need of both commemoration and remediation, ultimately making heritage preservation quite complex and expensive. This dissertation will explore how a community that desires to preserve and commemorate its history, articulates and negotiates that desire in the face of sometimes overwhelming opposition. In this case, the opposition comes from a well-funded organization, often with the support of development-oriented community groups, aimed at remediating the waste streams that emanated from that very same historic landscape, with the historic resources in question standing in the way of the simplest and most linear forms of remediation.

Peter Howard defines heritage broadly as anything, including material objects, ideas, customs, and practices, anyone wants to save or remember for any reason. ${ }^{1}$ For the purpose of this dissertation, heritage is simply reflected in the recognition that historical events represented by surviving material culture have helped shape the present, and that those material things and events that have the most relevance, integrity, and significance are worthy of remembrance and some sort of commemoration, documentation, or preservation. Scholars such as David Lowenthal and Mike Wallace place heritage in a broader social context by critiquing its practice when used selectively to promote nationalist ideals or false identities, and extolling its virtues when used to articulate positive or negative historic events that shaped the present. This work, however, will not judge the specific choices communities make or argue the significance of their choices. Rather it will accept that heritage practice, as broadly defined, is good for a community

\footnotetext{
${ }^{1}$ Peter Howard, Heritage: Management, Interpretation, Identity (New York: Continuum, 2003), 6.
} 
and that the better a community can define, manage, and protect its heritage, the stronger its identity will be. ${ }^{2}$

\section{Dissertation Format}

This dissertation will consider historical events leading to industrial heritage conflicts by examining the broad technological and environmental history of copper smelting, then look more specifically at important historic copper mining and smelting communities in Michigan, Tennessee, and Montana. Each of these three districts has existing heritage plans which are enriched and contested in various ways by the environmental consequences of its mining periods. This dissertation will focus specifically on the issues of smelting technology, waste generation, environmental remediation, and smelting landscape preservation. Part I, comprising Chapters 1-4, will explore the technological and environmental histories of copper smelting that led to American domination of copper production from the 1880s to the 1980s. Chapter 1, The Basics of Copper and Smelting, focuses on copper uses, ores, and general smelting practices. Chapter 2, A Short History of Copper Smelting through 1640, develops the five-thousand year history of the copper smelting blast furnace, culminating in the emergence of standard practices in $16^{\text {th }}$-century Germany, and examines the early recognition of smelter waste and environmental degradation. Chapter 3, The Welsh System, develops the nearly 200-year dominance of the Welsh smelting system based on

\footnotetext{
${ }^{2}$ See: David Lowenthal, The Past Is a Foreign Country (New York: Cambridge University Press, 1985), -The Heritage Crusade and the Spoils of History (New York: Cambridge University Press, 1998), and Mike Wallace, Mickey Mouse History and Other Essays on American Memory (Philadelphia: Temple University Press, 1996).
} 
the perfection of reverberatory furnace practice, and discusses concerns about and early lawsuits related to waste streams emanating from the concentration of $19^{\text {th }}$-century smelting activity in Swansea, Wales. Chapter 4, The American System, discusses the adaptation of European copper smelting technology in the United States, and significant increases in copper demand brought on by electrical applications. The chapter then looks more closely at smelting technology in the three American copper districts based chronologically on when each district started large-scale copper mining and smelting: the Michigan Copper Country on the Keweenaw Peninsula in Michigan's Upper Peninsula (1840s), the Ducktown district in southeast Tennessee (1850s), and the Butte-Anaconda district in southwest Montana (1880s).

Part II looks more closely at these three districts, exploring the histories of the districts leading to significant early waste disposal problems and the discovery of new environmental problems after each location had largely stopped mining and smelting that ultimately led to a listing on the Superfund National Priorities List (NPL). The chapters also examine for each district, early, pre-Superfund heritage plans and later heritageenvironmental conflicts and their resolutions as communities attempted to preserve elements of their past while remediation professionals worked to clean up the landscape. Chapter 5, Montana, discusses the placing of the Butte-Anaconda district on the NPL in 1983 and the heritage discussions, plans, and preservation projects that occurred over a fifty-year period. Chapter 6, Ducktown, discusses the district's principal responsible party's efforts to keep the location from being officially labeled "Superfund" in the 1990s, and the privatization of both the cleanup activities and later heritage decisions. 
Chapter 7, Quincy Smelter, discusses the Michigan Superfund project that began with a NPL-listing in 1986, but whose last remaining historic smelter was not considered for remediation until 2004, when efforts to include it in the national park fell short and asbestos issues grew more important. The Smelter's ultimate fate was still not officially determined as late as July, 2009. The Conclusion introduces the Model, a predictive method to explain the historical processes rural mining districts undergo as mining peaks, diminishes, and ends, leaving communities with lower population, greater economic distress, contaminated landscapes, and poor images, and the efforts of those communities to respond to these problems.

Ultimately, this dissertation will demonstrate that, despite the well meaning intent of federal laws designed to protect both heritage and the environment, not all people share the same values, perceptions, or interpretations of the landscape, and conflicts will most certainly rise without clear, predictable outcomes. But a community with a strong organization, knowledge of laws and practices, and persistence has the best chance of protecting their cultural resources under threat from remediation.

\section{A note on site selection}

This dissertation aims to examine the conflicts between heritage planning and environmental remediation. While conflicts between the two are played out under a variety of circumstances, copper smelting proves the ideal subject, not only because copper was one of the most important and heavily mined metals throughout history, but 
because its extraction and processing have led to some of the worst environmental degradation.

Copper was responsible for the first major mining boom in the United States and quickly led to U.S. global production-dominance because of the nation's vast reserves and innovative adaptation of European technology. Further, copper mining and smelting led to some of the largest Superfund projects in the country, including one whose estimated costs should exceed one billion dollars. While iron was the most important metal historically and was mined and processed on a much larger scale than copper, its ores tended to be richer and generally much less toxic to human health than copper ores. Further, iron's heritage is well established with many preserved blast furnaces, steel facilities, bloomeries, foundries, blacksmith shops, and several heritage trails and state and national parks. Other metal production, such as gold and silver mining and smelting, tended to be on a smaller scale than copper, largely because of their rarity, and therefore less of an environmental impact, and lead, although more toxic than copper, was only produced at about one-third the rate of copper in the $20^{\text {th }}$-century, never generated the historic-interest of copper mining. Its major mine sites were only just being considered for NPL listing in mid-2009.

The three sites selected for this study represented significant copper mining and smelting regions that pursued heritage planning amidst Superfund cleanups. Both the Michigan and Montana copper districts led global production at one time and had (have) high historical integrity. Both had multiple heritage projects that documented and commemorated their histories, and both had landscapes considered toxic enough to 
warrant Superfund cleanups, although the Michigan district was significantly less contaminated than Montana's. Montana's heritage community was (and is) dominated by local groups and Michigan's by a formal combination of local groups, Michigan Technological University, and the National Park Service. The Tennessee copper district was for short periods the second or third leading copper producing region in the country, and, while it never produced at the rate of either Michigan or Montana, it developed important by-product processes including the largest sulfuric acid plant in the world. While its contamination problems were nearly as bad as Montana's, except for scale, its cleanup company negotiated to keep its district away from an official Superfund designation but still followed all Superfund remediation protocols— - but not the heritage considerations required for federal agencies.

Other important copper districts that warranted consideration for this dissertation included the mining district in Ely and Elizabeth, Vermont. This region had a very long history of copper production from the 1820 s to the 1920 s, at times rivaled the Tennessee district in terms of production, and has had an on-going Superfund remediation project since 2001. Unlike Michigan, Montana, or Tennessee, however, its heritage component is being managed by the State Historic Preservation Officer as mandated by the National Historic Preservation Act (NHPA), in the manner that the NHPA and the Superfund law intended. While the project is not controversy-free, it is in many respects following the model for federal projects involving heritage that the other three sites should have followed, and as such, does not present as great a conflict as the other districts. Some Arizona copper sites could also have been considered because of their production 
dominance following Montana. However, Arizona mining and smelting landscapes, several of which are still active, have not generated Superfund attention like the other three sites. Similarly Utah, which has led copper production for much of the $20^{\text {th }}$ century, is still active and thus not covered by Superfund. Swansea, Wales, could have been considered for an international comparison, because for over a century its copper smelters dominated global copper production and generated the first documented pollution lawsuits. But its smelting landscape is not in conflict. Its community decided after the final decline of metallurgy in the region to demolish much of its historic copper smelting landscape and promote the region's proximity to the ocean as its primary tourist draw rather than its industrial heritage. While all of these sites are or were important producers, none of them attempted to use their histories, and hence heritage, to revitalize their economies to the extent the Michigan, Tennessee, and Montana copper districts have.

\section{Scholarly Context}

Most scholarly work on the history of mineral districts through the 1980s has focused on the opening and peak periods of production, with perhaps minor consideration for their slow decline. This dissertation focuses on the after-effects of mining and smelting production and adds to a growing body of literature examining landscapes and waste-streams as an important feature of historical inquiry. The Environmental History movement, begun in the 1980 s, seeks to explore the relationship between human activity and nature. Important works like William Cronon's Nature's Metropolis (1991) and 
Richard White's Organic Machine: the Remaking of the Columbia River (1995) interpret landscape- change and perceptions of landscape, as a direct construction or reflection of human agency, especially as the land itself became less of a wilderness and more of a commodity with American westward expansion. More specific to mining contexts, Duane A. Smith's Mining America (1987) and Richard Francaviglia's Hard Places (1991) look at significant changes mining made to the landscape. Smith's work is a history of the mining industry's actions and attitudes toward the environment and charts the evolution of wanton waste disposal practices of $19^{\text {th }}$ - and early $20^{\text {th }}$-century mines that had evolved by the later $20^{\text {th }}$-century to at least minimal consideration of remediation. Francaviglia's work seeks to understand and contextualize the current, abandoned landscape of former mining activity, including former communities, unused structures, and significant waste piles. ${ }^{3}$

Adding to the broader studies above, the following works look at specific copper mining locations in a broad context and consider the generation of colossal waste streams and sinks. Fred Quivik's dissertation, Smoke and Tailings, an Environmental History of Copper Smelting Technologies in Montana 1880-1930 (1991), explores the social, legal, and technological history of responses to early and major smelter smoke and concentrator tailings discharges into the environment surrounding Butte and Anaconda, Montana. Timothy LeCain's dissertation, Moving Mountains: Technology and the Environment in Western Copper Mining (1998), explores the idea of mining efficiency that evolved from

\footnotetext{
${ }^{3}$ William Cronon, Nature's Metropolis : Chicago and the Great West (New York: W.W. Norton, 1991); Richard White, Organic Machine: The Remaking of the Columbia River (New York: Hill and Wang, 1995); Duane A. Smith, Mining America: The Industry and the Environment. 1800-1980 (Lawarence: University of Kansas Press, 1987); and Richard V. Francaviglia, Hard Places: Reading the Landscape of America's Historic Mining Districts (Iowa City: University of Iowa Press, 1991).
} 
an early conservation principle at mining universities into a corporate-economic goal of lowering costs and expanding throughput, ultimately leading to considerably more production and production waste. Gavin Bridge's dissertation, Regulating Nature: the Ecological Origins and Environmental Implications of Restructuring in the U.S. Copper Industry (1997), and Kip Curtis' dissertation, An Ecology of Industry: Mining and Nature in Western Montana (2001), both explore western mining from the perspective of significant and destructive landscape change. ${ }^{4}$ Even Cronon touches on copper mining in "Kennecott Journey," in Under an Open Sky: Rethinking America's Western Past (1992). He places the 1990s ghost town of Kennecott, Alaska, into an historic environmental context exploring the effects of distance, isolation, and local resources (organic and inorganic) on the Euro-American mining community, and the effects of the mine on urban areas in the Continental U.S. concluding that "the mere existence of ... minerals did not in and of itself determine the events that took place [in Kennecott].. ${ }^{5}$ While these works largely examine the formation and consequences of large mining waste streams and dumps from an environmental history perspective, a few authors have approached similar landscapes and worked to define their value as it exists today, largely from a heritage context. Mary Elizabeth Curran's master's thesis, The Contested Terrain of Butte, Montana: Social Landscapes of Risk and Resiliency (1996) explores the idea that the long-term residents of Butte were less concerned about the

\footnotetext{
${ }^{4}$ Fred Quivik, "Smoke and Tailings: An Environmental History of Copper Smelting Technologies in Montana 1880-1930" (PhD dissertation, University of Pennsylvania, 1998); Timothy J. LeCain, "Moving Mountains: Technology and the Environment in Western Copper Mining" (PhD dissertation, University of Delaware, 1998); and Kent Curtis, "An Ecology of Industry: Mining and Nature in Western Montana" ( $\mathrm{PhD}$ dissertation, University of Kansas, 2001).

${ }^{5}$ William Cronon, "Kennecott Journey: The Paths out of Town," in Under an Open Sky: Rethinking America's Western Past (New York: W. W. Norton and Company, 1992), 48.
} 
toxins in the landscape than they were with their history and heritage. David Robinson's "Heaps of History" (2000), describes Toluca, Illinois, residents who sought historic landmark status for "Jumbo," a large coal waste pile, because of its prominence on the landscape and heritage value to the community. In "Living in Anthracite: Mining Landscape and Sense of Place in Wyoming Valley" (2001), Goin and Raymond discuss the loss felt by eastern Pennsylvania residents when their historic coal waste piles disappeared because of remediation efforts and, with them, the loss of historic context for one of the last remaining historic coal breakers and the loss of historic identity for the communities. Don Hardesty, echoing similar sentiments, decries the loss of historic data in the complete remediation of mining and other industrial waste dumps in "Issues in Preserving Toxic Wastes as Heritage Sites" (2001). ${ }^{6}$

Further, Fred Quivik's important articles from 2000 and 2001 focus on waste streams. The first, "Landscapes as Industrial Artifacts: Lessons for Industrial Archeology" (2000), reflecting his dissertation, argues that industrial archeology had long looked only at the productive side of manufacturing and that there is almost as much to learn from the waste streams and the destructive side of manufacturing. In a second article, "Integrating the Preservation of Cultural Resources with Remediation of Hazardous Materials: An Assessment of Superfund's Record" (2001), he argues that, despite federal laws mandating that all activities executed with federal involvement or

\footnotetext{
${ }^{6}$ Mary Elizabeth Curran, "The Contested Terrain of Butte, Montana: Social Landscapes of Risk and Resiliency" (Master's Thesis, University of Montana, 1996); David Robertson, "Heaps of History: Toluca and the Historic Longwall Mining District," Journal of Illinois History 3, Autumn (2000), 162-184; Peter Goin and Elizabeth Raymond, "Living in Anthracite: Mining Landscape and Sense of Place in Wyoming Valley, Pennsylvania," The Public Historian 23, no. 2 (2001), 25-49; and Donald Hardesty, "Issues in Preserving Toxic Wastes as Heritage Sites," The Public Historian 23, no. 2 (2001), 19-28.
} 
funding consider and mitigate potential impacts to cultural resources eligible for the National Register of Historic Places, the U.S. Environmental Protection Agency in general, and under Superfund specifically, has a poor record regarding legally-required heritage protection. ${ }^{7}$

Except for Quivik's “Integrating the Preservation of Cultural Resources” article, these works mostly describe historic waste generation, landscape change, environmental history, or current heritage values associated with the contaminated industrial landscape. They do not explore the gap between environmental remediation and heritage management beyond raising awareness. This dissertation will bridge that gap, looking at the broad technological history of copper smelting that led to significant environmental problems, then, taking a cue from Quivik's “Integrating the Preservation of Cultural Resources" article, examine the conflict that develops when remediation officials have to negotiate with heritage planners at sites that deserve to be both remediated and preserved. While all the works cited here inform and enrich this dissertation, other heritage concepts are needed to fully understand how communities in historic mining districts whose mining wastes have been determined contaminated enough to warrant managed remediation by the Environmental Protection Agency or state environmental agencies, engage their landscape. These include the notions of perception and value, which often inform each other and help direct actions. For example, to a person or group who values heritage, a landscape full of old building and mining structures is perceived as an

\footnotetext{
${ }^{7}$ Fredric L. Quivik, "Landscapes as Industrial Artifacts: Lessons from Environmental History," IA: The Journal of the Society for Industrial Archeology 26, no. 2 (2000), 55-64, and —_, "Integrating the Preservation of Cultural Resources with Remediation of Hazardous Materials: An Assessment of Superfund's Record," The Public Historian 23, no. 2 (2001), 47-61.
} 
important historical asset and potential economic resource. Hence, they fight to preserve them. A person or group disinclined toward heritage and more inclined toward new development may see old buildings or a landscape full of mining ruins as blight and a hindrance to progress and, in the event of serious contamination, something that should be remediated no matter what the cost.

In the report "Values and Heritage Conservation" (2000) on the changing value of values in conservation decisions, Getty Conservation Institute editors Avrami, et al., state that "values are critical to deciding what to conserve... [and] the real source of the meaning in heritage. ${ }^{\prime 8}$ Material culture, they continue, "has different meanings and uses for different individuals and communities. Values give some things significance over others and thereby transform some objects and places into heritage." ${ }^{9}$ The 2000 report and the follow-up report, "Assessing the Values of Cultural Heritage" (2002), recognize not only the importance of value to individuals and communities, but that through a recent democratization trend, new groups, such as professionals from other fields and special interest associations, tend to make heritage decisions "complex negotiations to which diverse stakeholders bring their own values." ${ }^{10}$ Avrami, et al., ultimately recognize that divergent social groups "will continue to ask more and more from material culture — and heritage in particular—as they negotiate identities, form communities, and seek a more salutary and prosperous future. The extent to which groups at all levels do

\footnotetext{
8 "Values and Heritage Conservation," ed. Erica Avrami, Randall Mason, and Marta de la Torre (Los Angeles: Getty Conservation Institute, 2000), 14.

${ }^{9}$ Ibid., 1,4 , and 7.

10 "Assessing the Values of Cultural Heritage," ed. Marta De la Torre and Randall Mason (Los Angeles: Getty Conservation Institute, 2002), 3, and "Values and Heritage Conservation," 68.
} 
this cooperatively or competitively is perhaps the greatest cultural and social question of next century."11

Another approach to understanding heritage focuses on two organizational directions in planning and management applied by Jon Price in 2006: the official, professional, state-sanctioned or top-down approach and the community-driven, local, or bottom-up approach. Price writes:

Official top-down heritage interpretation...is concerned with the development of the visitor, and concepts of historical validity. It has a didactic intent, and is concerned to place its subjects in context in a perceived and social continuum... [and] tends to deal with broader context of the industrial activity and places the activity and its context in juxtaposition with examples of comparable experience elsewhere.

Community-led interpretation, on the other hand is concerned with the validation of recent experience...to explain the behaviour and activity of preceding generations to present generations, and it places its subjects in a polarized context of 'then' and 'now' ... and tends to deal directly with the detail of process, whether strictly industrial... or ancillary domestic. ${ }^{12}$

In each of the three regions studied in this dissertation, both forms appear.

Bottom-up, community-led heritage and interpretation planning is led by grass-roots efforts, local museums, and historical societies, and top-down interpretation is represented by National Register of Historic Places districts and nominations, Historic American Engineering Record documentation projects (in two districts), a National Historical Park, and, in one district, the EPA and a cleanup company. No district had just one type of organization; each had varying degrees of top-down and bottom-up heritage

\footnotetext{
11 "Values and Heritage Conservation," 14.

${ }^{12}$ Jon Price, "Interpreting Industrial Heritage," in Heritage Interpretation, ed. Allison Helms and Marion Blockley (New York: Routledge, 2006), 111-112.
} 
planning that argued, with varying degrees of success, for preservation amidst remediation planning.

In addition to concepts of value and perception, I also propose a few terms to help elucidate this work. Successful mining districts largely had periods of increasing production after they were established, longer periods of high production, and ultimately a period of decline. In all three sites examined here, the period of decline was followed by a documentation of serious environmental contamination and a Superfund cleanup. The declining mining period, when a region was not as economically productive as it once was, experienced dwindling population levels that led to a blighted, abandoned, and demolished landscape. Often, the remaining population was forced to deal with economic downturns and significant contamination that led to a general, community-wide sensation of loss or an ethos of defeat that could trigger heritage projects to commemorate the past.

In other respects, the term "glory days" could be used to describe periods of high production, booming mining towns, and general success for miners, mine owners, and townspeople. However, the term is never used in a contemporary sense. It is always used to refer back to a period more prosperous than the present. In some respects, it is this idea that many locally-driven, bottom-up heritage projects, to the consternation of historians like David Lowenthal, hope to use to lure and educate tourists about the importance of their once important district. These are the glorified, heroic landscapes that heritage projects try to recapture or celebrate in some way. 
The ethos of defeat is often worsened not only by contamination, but the attention generated by on-going environmental remediation. To end this ethos, however, remediation becomes necessary to both clean and remove the stigma, often to the detriment of the heroic landscape. But heritage is also a means of alleviating defeat by drawing attention from declining mineralogical importance to remembering the heroic period. Inevitably, neither remediation nor remembrance can be executed without negotiation and compromise, especially in historically significant contaminated areas. Some environmental treatments may be modified and some heritage lost, leaving a compromise landscape.

\section{Legal Framework}

Heritage protection and environmental remediation are important components of modern western societies, both adding value to historic places which, at times, include very seriously devalued post-industrial landscapes. As such, nations write laws and establish practices to promote heritage and remediate contamination and assign agencies to enforce their laws.

The United States, Great Britain, and many other nations have heritage laws and professional standards of practice to identify and protect the material things, places, and traditions of the past based on the inherent values of each country. In most nations, a relative value is based on the significance of a particular artifact, structure, landscape, or tradition; but heritage can be significant on a personal, local, regional, national, or global level. Value and significance are determined by the meaning a particular cultural object, 
location, or practice has to the culture identifying and protecting it. The home of the first president of the United States, for example, is a key physical representation of the roots of this nation. As such, it has great symbolic value and hence great significance on a national level and is protected, preserved, and interpreted in a manner befitting the most important structures in this country.

Heritage laws and policies evolved in the United States based on and stemming from traditions established for the preservation of important ecological sites, and the primary responsibility for national heritage thus rests with the National Park Service, an agency whose purview encompasses the protection of significant landscapes and sites of historical importance and/or natural beauty. Over a century, the United States developed a system to identify and document structures and landscapes of regional and national significance, and to preserve and interpret significant structures and landscapes held privately, regionally, and federally. The U.S. Antiquities Act of 1906 first permitted the official designation of historic landmarks and created penalties for harm caused to federally-owned cultural resources. Sixty years later, the National Historic Preservation Act of 1966 (NHPA) authorized the formation of the National Register of Historic Places, created and assigned duties to the State Historic Preservation Offices (SHPO), and established rules for managing historic resources on federal property.

While some states have state-level registers of historic structures and communities have historical societies and preservation boards, the most important list for heritage designation in the United States is the National Register of Historic Places. To be eligible for listing, a privately- or publically-owned site must meet certain criteria of 
regional or national significance, be in its original location, and largely be free from major ornamental or structural changes since its time of importance. Sites on the National Register that meet an even higher level of national significance can be elevated to National Historic Landmark status. As of 2008, over 80,000 properties, representing over 1.4 million individual resources, are listed on the National Register, but only 2,400 of them meet the criteria for National Historic Landmark status. ${ }^{13}$ While these designations provide little legal protection for privately-owned sites, a listing at a minimum requires some form of documentation that proves a site's significance and authenticity, thereby fulfilling an important heritage step by creating a record of an important structure or landscape. ${ }^{14}$

The most important parts of the NHPA for this dissertation are Sections 106 and 110. ${ }^{15}$ Section 106 requires that all undertakings or projects executed with federal funds or requiring federal permits consider and mitigate the potential damage to cultural resources worthy of inclusion on the National Register. Further, Section 110 designates the heads of each federal agency to be responsible for and develop plans and procedures to protect historic resources eligible for the National Register within their own agencies. The NHPA (established and) requires State Historic Preservation Officers (SHPO) in each state to determine National Register-eligibility of potentially impacted cultural resources and approve mitigation efforts, and provides for a National Advisory Council to address national heritage issues, advise the president and congress on historic

\footnotetext{
${ }^{13}$ See "Welcome to the National Register of Historic Places" at www.nps.gov/nr/about.htm, accessed September 29, 2008.

${ }^{14}$ If a privately-owned site on the National Register is altered or changed so much that it no-longer meets the requirements for listing, the only penalty is de-listing.

15 "National Historic Preservation Act of 1966," in Public Law 102-575 (1966).
} 
preservation, and resolve conflicts. If, for example, the Air Force desires to construct a new hangar building at a base in the United States and the desired location includes the archaeological remains of an $18^{\text {th }}$-century Native American campsite meeting the National Register eligibility requirements, then the Air Force must consult with SHPOs and reach agreements to mitigate the damage to that site. Mitigation, however, does not necessarily mean cancelling a project, but, based on the site's significance, mitigation could mean, at a minimum, excavation to recover material culture and spatial data prior to construction or, at a maximum, if the site proved to be associated with a significant historical figure for example, finding other ways to execute the hangar project without impacting the site.

Privately owned sites or those owned by states or municipalities fall under different consideration. While no specific federal laws exist to formally protect privately-owned heritage sites in this country, tax incentives encourage private historic preservation efforts, and community historic districts can enforce protective covenants for included properties to ensure they are maintained appropriately.

Overall, laws and practices exist to protect heritage in the United States especially if the federal government is involved through, licenses, permits, projects, or financing, but the relative value of individual heritage sites or traditions to the acting agency are almost inconsequential. The laws require consideration of impacts by federal projects on all heritage, as determined eligible by the National Register criteria, in the belief that the preservation of the historic things, places, and traditions of the past is in the best interest of the Nation. 
A second set of United States laws enacted in the latter half of the $20^{\text {th }}$ century stemmed from a national response to the lasting effects of industrialization and its impacts on human health. These laws evolved in part, from a history of nuisance complaints against polluters dating as far back as the $17^{\text {th }}$ century. For example, early $19^{\text {th }}$-century Welsh farmers, whose crops and livestock had died because of smelter smoke from Swansea, were among the first to use nuisance laws to attempt to limit industrial pollution. Early $20^{\text {th }}$-century American farmers, state governments, and federal agencies similarly sought injunctions against or damages from large copper smelting sites because of significant pollution injuries to property. The fact that the majority of the early cases brought by individuals were settled, dismissed, or lost by the plaintiffs, and the governments' cases largely resulted in negotiated settlements, suggests that economic growth was more important to the nation as a whole than then known pollution nuisance until late in the $20^{\text {th }}$ century when the more serious effects of contamination became much more identifiable and quantifiable.

While these cases highlighted the potential impact of industrial activity on human health, they did little to alter the expansive growth of the economy and spread of ever more complex industrial activity. Not until the mid $20^{\text {th }}$-century did people in the United States begin to question the lasting effects of industrial activity on the landscape, especially as environmental disasters and deaths from contamination seemed potentially preventable and studies demonstrating the effects of long-term exposure to more invisible toxins became more alarming. Beginning in the 1940s, Congress passed laws regulating the output and transportation of hazardous substances and, in 1970, created the 
Environmental Protection Agency, whose mission, simply stated, was to protect human health and the environment. It was to execute its mission by establishing pollution standards, monitoring industrial effluent, accessing fines, and prosecuting pollution violators.

The Clean Water Act (1972), that substantially expanded the 1942 Federal Water Pollution Control Act, and the Clean Air Act (1970), that substantially expanded the Air Pollution Control Act of 1955, went a long way to curb current and future pollution by setting limits to discharges and establishing penalties for violations. The Resource Conservation and Recovery Act of 1976 (RCRA) established rules for the transportation and disposal of hazardous wastes and provided conservation standards for natural resources. While all three of these acts had implications for current and future pollution, they did little to remediate the continued effects of past pollution and existing hazardous waste deposits. While the 1977 Surface Mine Control and Reclamation Act collected taxes from active coal mining to be used for abandoned mine reclamation efforts, it wasn't until 1980 that the government addressed a broader spectrum of neglected waste. In 1980, Congress passed the Comprehensive Environmental Response, Compensation, and Liability Act (CERCLA), more commonly referred to as "Superfund," to identify significant sites of past pollution, prioritize the sites based on potential damage to human health, and plan for and execute the remediation of those sites. Further, if the original polluters, their later corporate owners, or current land-holders were economically viable or legal entities, then the EPA, which administers Superfund, could label them a Potentially Responsible Party (PRP) and attempt to force them to manage the cleanup or, 
at a minimum, seek to recoup the cost of the clean up. In those instances where a PRP could not be identified, CERCLA and the 1986 Superfund Amendments and Reauthorization Act (SARA) provided public money, the super-fund, raised from chemical and petroleum industry taxes, to pay for the remediation of significantly polluted sites.

For a site to be remediated under Superfund, federal studies called Preliminary Assessment/Site Inspection (PA/SI) must first determine the extent of the contamination or confirm findings from other state or federal studies. These studies establish a threat ranking based on potential public health impacts for individual sites and, if significant enough, lead to listing on the National Priorities List (NPL) that officially defines a location as a Superfund site. The next step, if the site requires a long-term permanent solution, is a Remedial Investigation and Feasibility Study (RI/FS) the EPA or PRP conducts to outline the threat and optional treatments. The final choices of remediation options, after considering public comments and opinions, are listed in the Record of Decision (ROD), a legal public document that the EPA and PRP are mandated to follow. Following the publication of the ROD, work plans, safety plans, and public involvement plans are created to execute the ROD, usually completed under the broad heading of Remedial Design and Remedial Action (RD/RA). ${ }^{16}$ One key component of the RD/RA is the Applicable or Relevant and Appropriate Requirements (ARAS) which require the EPA to identify and enforce other federal and state statutes that apply to the clean up and

\footnotetext{
16 "Cleanup Process," U.S. EPA, http://www.epa.gov/superfund/cleanup/index.htm, accessed July 11, 2009.
} 
federal undertakings. Often these include RCRA, the Endangered Species Act, and Sections 106 and 110 of the National Historic Preservation Act.

Some of the 11,000 sites listed on the National Priorities List are military bases, warehouses, or transportation sites, but the majority of them were listed because of longterm industrial activity and contamination. Because of this longevity, many of these places also hold historic significance, as defined by the National Register criteria, to American economic, social, and industrial history. Arguably, much of America's importance on the world stage can be attributed to its rapid growth and industrial output between 1850 and 1950 .

Prodigious American production affected the outcome of two world wars, changed the structure of global wealth, shifted the seats of world power, firmly established a middle-class, and, by and large, created the consumer economy. All of this was done over a century with little regard for the destination of the non-commercial byproducts of production. Factories dumped waste water into rivers and oceans, vented caustic gasses into the atmosphere, and allowed chemicals to seep into soils and groundwater. Mines and smelter sites, often in sparsely populated areas, simply left their waste tailings and slag wherever they could and usually only considered them again if they interfered with production or could be recycled for additional profits.

Many old industrial sites therefore have dichotomous legacies. On one hand, they hold significance to American history and mark economic, social, and technological development and, as such, are important heritage sites. On the other hand, they are responsible for many of the most egregious pollution releases requiring extensive clean- 
ups and incurring considerable cost. Federal laws articulated by the NHPA and CERCLA exist to protect or correct both legacies for the betterment of the public. CERCLA, despite its specific health-relevance to contaminated communities, is not exempt from the provisions of Sections 106 and 110 of the NHPA, and as such, the EPA, is required to consider historic resources it encounters.

However straight forward the National Historic Preservation Act is, federal agencies are mission-driven, shaped by the personalities of their various staffs, and not necessarily inclined to appreciate local heritage as much as the communities they work in do. Further complicating heritage practice in contaminated communities, the EPA in general does not have a strong institutional understanding of heritage. It has a small twoperson heritage staff within its compliance and enforcement division that serves the remaining 17,000-person EPA. ${ }^{17}$ In an almost too simplistic approach, the heritage staff distributes a pamphlet titled, "Historic and Archaeological Resource Protection for USEPA Personnel” with chapters titled, "Why Should you care about Historical and Archaeological Resources?" (Answer: it's the law, regulations require it, it's policy, and it's a good idea), and "What are 'Cultural Resources'?"18 There are few other training resources available for EPA, or state-level environmental departments for that matter, to access heritage policy beyond a single preservation-remediation course taught by the private National Preservation Institute and a book by Tom King, titled Cultural Resource

\footnotetext{
17 "Who Are We and How Are We Organized?" http://www.epa.gov/epahome/aboutepa.htm, accessed July $11,2009$.

18 "Historic and Archaeological Resource Protection for USEPA Personnel," ed. Office of Enforcement and Compliance Assurance (Washington, DC: U.S. EPA, 2007), 1-6.
} 
Laws and Practice (2008), outlining regulations affecting cultural resources including CERCLA although it is mostly geared toward heritage professionals. ${ }^{19}$

While the EPA is not positioned institutionally to respond to heritage issues at Superfund sites, many communities are equally unfamiliar with or not positioned well to use the law. Without a strong voice from the community to force EPA compliance with Sections 106 and 110 of NHPA, confrontations become one-sided and heritage is often lost, or only minimally considered.

To provide a background for understanding how copper production historically created environmental problems that would eventually lead to remediation efforts, the opening section of this dissertation addresses the broad history of copper smelting. This portion of the dissertation is mainly synthetic, drawing on the work of numerous scholars. However, it does two things that previous scholarship has not. First, it provides a broad synthetic account of copper smelting and its environmental impacts from antiquity to near present. Past studies have focused merely on specific smelting sites in specific times and even broader studies like Charlie Hyde's Copper for America have focused only on specific nation-states. Second, through specially constructed flow charts, the chapters in Part I attempt to provide a basic idea of how often-very-complicated historic smelting technology operated and a clearer understanding of how and why each of these technological processes created environmentally hazardous materials.

\footnotetext{
${ }^{19}$ See: Thomas King, Cultural Resource Laws and Practice (Walnut Creek, CA: Altamira Press, 2008). and "CERCLA and NPA Coordination for Superfund Sites," NPI, http://www.npi.org/sem-cercla.html, accessed July 11, 2009.
} 


\section{PART I}

An examination of the broad technological and environmental history of copper smelting from the earliest furnaces to the development of the German and Welsh systems to the culmination of modern practice in the United States. 


\section{CHAPTER 1. THE BASICS OF COPPER AND SMELTING}

Copper smelting could be one of the oldest industrial professions. Unlike other early manufacturing pursuits such as fire-building, stone shaping, pot-making, housebuilding, and clothes-making, however, copper production was much more complex. The extraction of chemically bound copper from its stone matrix required an expectation, even if not defined or entirely understood, that complex chemical and thermodynamic processes applied to certain types of rocks would yield repetitive results. Copper's earliest known uses date to the sixth millennia BCE, likely the result of working relatively pure, but rare native copper. The first purposely smelted copper dates to only 3500 BCE. $^{20}$

Copper and copper alloy production were a significant metallurgical process from the time they originated. The metal's cost fluctuated based on production and supply levels accentuated by wars and economic depressions, but some demand for copper always existed and tended to increase throughout history and new uses for the metal developed and populations grew. Arguably, copper and its alloys were the most important metals from $3500 \mathrm{BCE}$ until the advent and diffusion of bloomery iron forges and rudimentary small batch steel making late in the second millennium BCE. Further, easily melted and cast copper-based metals rivaled iron's full importance until the advent and diffusion of blast furnaces between the $6^{\text {th }}$ and $15^{\text {th }}$ centuries $\mathrm{CE} .{ }^{21}$

\footnotetext{
${ }^{20}$ R. F. Tylecote, A History of Metallurgy, 1st ed. (London: Institute of Metals, 1976), 7-8.

${ }^{21}$ Ibid., 40, 58, and 65.
} 
Copper attained this importance because it was not only more plentiful than gold and silver, but its bronze and brass alloys were considerably stronger, relegating the early precious metals chiefly to ornamentation and commerce. While considerably less plentiful than iron, its chief rival, copper had a notably lower melting point, so founders chose it and its alloys for virtually all cast metal objects requiring certain strength characteristics from bells to sculpture to cannon until the second millennium $\mathrm{CE}$ when cheap cast iron started to become widely available. ${ }^{22}$ Bronze, a copper alloy, was generally stronger than and as ductile as wrought iron, but less strong than steel. Despite the preponderance of iron on the planet, pre-modern steel-making could only be done in small batches with rare phosphorous-free iron ore in a forge crucible and was generally limited to weapons and tools.

While few can argue against the benefits of selecting a strong, ductile, noncorrosive, easily cast metal like bronze over wrought iron during the Iron Age, the disadvantages of iron become nearly inconsequential given its much wider availability compared to copper and its much lower price, estimated at only $20 \%$ of that of bronze during the Roman period. ${ }^{23}$ While it is difficult to quantify the number of early Iron Age iron ore deposits compared to then known copper ore deposits, a comparison of $20^{\text {th }}$ century pig-iron production to $20^{\text {th }}$ century copper production gives a general indication of just how much more plentiful iron is. The average yearly world production of pig iron

\footnotetext{
${ }^{22}$ Tin, zinc, and lead all have considerably lower melting points than copper and founders could have selected them individually for some uses, but, by themselves, their very low tensile strength rendered them largely useless for any functioning tool or weapon. Tylecote, Ibid. p. 38, suggests that while pewter, a lead-tin alloy, was used in some applications as early as $1100 \mathrm{BCE}$, lead overall was not an important metal until the Iron Age.

${ }^{23}$ Nathaniel Southgate Shaler, Man and the Earth (New York: Fox, Duffield \& Company, 1905), 48.
} 
from 1910-2004 was 421,276,596 metric tons; the average yearly production of copper from 1900-2004 was 4,473, 058 metric tons. ${ }^{24}$ In other words, based on $20^{\text {th }}$ century data, copper production was just about one percent (1.06\%) that of iron.

\section{Copper Properties}

Historically, uses for copper expanded as its specific properties - ductility, alloyability, corrosion-resistance, and conductivity—were successively exploited. The first copper users prized the ductility of largely pre-industrial native or refined pure copper. Because of its softness and density, copper could be hammered and hardened into shapes such as crude knife blades, points, and tools but also formed and polished into colorful decorative and religious objects. Due to the greater availability of native copper and a scarcity of native gold in parts of pre-industrial sub-Saharan Africa, copper became as precious a decorative metal for some tribes as gold was for others. Indeed, copper's aesthetic value to African tribes propelled its use in the Dutch and British slave-trades; the metal formed one leg of a mercantile triangle the sent copper from Europe to Africa to buy slaves who were sent to the Americas to produce sugar and rum (and profits) for European consumption. ${ }^{25}$ North American native copper played a similar role for

\footnotetext{
24 "Pig Iron Statistics," U.S. Geological Survey, http://pubs.usgs.gov/ds/2005/140/, accessed March 13, 2008, and "Copper Statistics," U.S. Geological Survey, http://pubs.usgs.gov/ds/2005/140/, accessed March 13, 2008.

${ }^{25}$ Eugenia W. Herbert, Red Gold of Africa: Copper in Precolonial History and Culture (Madison: University of Wisconsin, 1984), 123.
} 
aboriginals here. As the only metal available for tool and weapon use, it found its way into extensive trade routes throughout the continent. ${ }^{26}$

The discovery that molten copper easily combines with other metals to form alloys, such as bronze and later brass, that have much greater strength and ductility than pure copper presented new opportunities. These alloys were used in the Bronze and early Iron ages for weapons, tools, coins, and structural and decorative objects, but copper's general rarity in the Earth's crust made them considerably more expensive and limited their use following the advent of iron. The lower melting points of copper $\left(1083^{\circ} \mathrm{C}\right)$ and bronze $\left(999^{\circ} \mathrm{C}\right)$, however, made them the primary cast metal until the refinement and technological diffusion of the blast furnace and the technological ability to reach temperatures high enough to melt and cast iron.

Contributing to copper's utility, especially in the early industrial age, was its superior corrosion resistance over wrought and cast iron and steel. From the dawn of the Iron Age, copper found use in metal applications in corrosive environments such as naval weapons, instruments, and architectural fixtures and piping. Pure copper's malleability allowed it to be rolled thin, providing long-wearing, non-corroding panels for preventing wood rot and infestation on roofs and ship bottoms. Loosely related to this third property, copper and its alloys are also non-sparking and were (and are) used to make tools for use in potentially flammable or explosive environments.

Copper's fourth property differs significantly from the first three. Up until the 1850s, copper and its alloys were used primarily for their physical properties alone:

\footnotetext{
${ }^{26}$ Susan R. Martin, Wonderful Power: The Story of Ancient Copper Working in the Lake Superior Basin (Detroit: Wayne State University Press, 1999), 185.
} 
malleability, strength, low melting point, and corrosion resistance. Copper's fourth primary property, and arguably the most significant, is its thermal and electrical conductivity. Silver is a near perfect conductor of heat and electricity, often serving as the reference point for determining/assessing conductivity in other materials. Copper is considerably closer to silver than any other element with a thermal conductivity $94 \%$ of silver's and an electrical resistance of $1.67 \mathrm{micro-ohm} / \mathrm{cm}$ compared to silver's 1.59 micro-ohm/cm. Gold, an even rarer metal than silver, is a distant third in thermal conductivity (71\%) and resistance (2.35 micro-ohm/cm). No other materials are even comparable.

Using the earlier approach to demonstrate elemental rarity, the average annual world production of silver from 1900-2004 was 9,111 metric tons, while gold was 1,191 metric tons. ${ }^{27}$ Therefore $20^{\text {th }}$-century silver production was only $0.20 \%$ of copper and gold only $0.02 \%$. While not as perfect a conductor, copper's greater availability made it the choice for thermal, communication, and electrical applications as they were developed in the $19^{\text {th }}$ century and diffused in the $20^{\text {th }}$ century.

\section{Copper Compounds}

In general, copper is found throughout the earth in three primary forms, each a copper mineral or compound surrounded by non-copper waste compounds often referred to as gangue. If the grouping of metal compound and gangue can be mined and extracted

\footnotetext{
27 "Silver Statistics," U.S. Geological Survey, http://pubs.usgs.gov/ds/2005/140/, accessed March 15, 2008, and "Gold Statistics," U.S. Geological Survey, http://pubs.usgs.gov/ds/2005/140/, accessed March 15, 2008.
} 
profitably, the combination is called ore, and the ratio of recoverable copper to the remaining elements and compounds determines the leanness or richness of the ore body. $^{28}$

Native copper is largely pure but still considered a copper mineral. It is found either as large, multi-ton masses or as small inclusions within larger stone deposits. While native copper exists in many locations around the globe, only the Lake Superior copper range proved to be commercially minable in the industrial and modern periods. Other native deposits, while too small to be worked economically, tended to be indicators of larger copper ore deposits, such as those in Africa and Chile.

Lake Superior native copper was found in three primary deposit types. First, some copper precipitated from volcanic flows as large masses or into fissures and cracks between already hardened rocks. Native American miners sought this copper because it was accessible with modest stone tools through relatively shallow mines. Later, following attempts by the French and English, these mass copper deposits formed the initial objective of the first large American mining boom. The other two native copper types, formed as tiny amygdaloid (almond-shaped) inclusions in a much larger basalt deposit or small pebble-sized inclusions dispersed throughout a conglomerated sandstone matrix called conglomerate, ultimately proved to be the more lucrative copper mining deposits in Michigan.

The other two primary forms of copper ore historically and currently are chemical compounds of copper and other dominant and trace elements. The two chief compounds

\footnotetext{
${ }^{28}$ Allison Butts, Copper: The Science and Technology of the Metal, Its Alloys, and Compounds (New York: Hafner Publishing, 1970), 21.
} 
are oxides (copper plus oxygen) and sulfides (copper plus sulfur). Chemically combined in those compounds are often other elements that need to be removed in the roasting or smelting process because of their detrimental effects on the final metal or their individual economic value. An inclusion of arsenic, for example, a common trace element found in many copper compounds and a significant, pre-bronze hardening agent for early copper users, of just $0.4 \%$ will reduce the electrical conductivity of the final metal by $50 \%{ }^{29}$

On the other hand, small amounts of gold and silver, also found in combination with copper, are often recoverable in the smelting process leading to enhanced revenues. ${ }^{30}$ In some cases, the recovery of an ancillary element grew so significant that it made copper the by-product. The Ducktown Sulfur, Copper, and Iron Company, for example, was founded to produce copper but ultimately earned more income from the sale of sulfuric acid. ${ }^{31}$

While the first large-scale American copper mining endeavors worked native coppers, the vast majority of the world's copper, dating back to the Bronze Age, came initially from oxide and later sulfide ores. By the mid 1950s, chemists had identified 165 different copper compounds, but only 16 were considered rich enough for commercial extraction. ${ }^{32}$ Nearly all non-native ore bodies originally formed as sulfide deposits, many with sections close to the surface directly exposed to the air or covered by an easily identifiable iron-rich gossan layer. Through the weathering action of rain and wind,

\footnotetext{
${ }^{29}$ Charles P. Bacha, Joseph L. Schwalje, and Anthony J. Del Mastro, Elements of Engineering Materials (New York: Harper and Brothers, 1957), 144.

${ }^{30}$ Tylecote, A History of Metallurgy, 14.

${ }^{31}$ Stuart W. Maher, "The Copper-Sulfuric Acid Industry in Tennessee," ed. Division of Geology, the State of Tennessee Department of Conservation, Information Circular (Nashville, Tenn: State of Tennessee, 1966), 26.

${ }^{32}$ Butts, Copper: The Science and Technology of the Metal, Its Alloys, and Compounds, 21.
} 
many of the exposed or near-surface sulfide ore bodies were converted to oxides as the sulfur was leached out or reacted with oxygen. ${ }^{33}$ This process tended to leave oxide ores near the surface of many ore beds that were easy to mine and smelt and became the first copper ores sought by the earliest copper smelters. ${ }^{34}$ Just below the oxidized layer was often a layer of sulfide ore that had been enriched by the copper leachates of the upper layers. ${ }^{35}$ Then, below the rich sulfide layer, less rich sub-layers of the original deposit that, although often very large, ultimately became too lean to mine. (See Table 1.1 and Figure 1.1)

\section{Melting and Smelting}

All copper produced, with the exception of hammered native copper, was initially processed in a molten state. In general, most smelting throughout history, including the practice used with Michigan's native copper, has been a thermodynamic process to physically and chemically drive off waste materials and purify the metal. Initially, some form of concentration or pre-smelting sorting was applied to reduce the levels of waste the smelters would need to process. These steps included crushing ore and physically removing waste materials or using chemicals to leach copper from low-concentration ores. More complex compounds, however, often required more extensive concentrating

\footnotetext{
33 Tylecote, A History of Metallurgy, 8; Butts, Copper: The Science and Technology of the Metal, 23; and H. O. Hofman, Metallurgy of Copper (New York: McGraw-Hill, 1924), 65.

${ }^{34}$ William Gowland, "The Metals in Antiquity," Journal of the Royal Anthropological Institute of Great Britain and Ireland 42 (1912), 239, and Tylecote, A History of Metallurgy, 8.

${ }^{35}$ Butts, Copper: The Science and Technology of the Metal, 23; Tylecote, A History of Metallurgy, 8.
} 
Table 1.1

Copper Compounds ${ }^{36}$

\begin{tabular}{|c|c|c|}
\hline Mineral & Composition & Copper content \\
\hline Native Copper & $\mathrm{Cu}$ & $100 \%$ \\
\hline \multicolumn{3}{|c|}{ Sulfide Minerals } \\
\hline Chalcocite & $\mathrm{Cu}_{2} \mathrm{~S}$ & 79.8 \\
\hline Covellite & $\mathrm{CuS}$ & 66.4 \\
\hline Bornite & $\mathrm{Cu}_{5} \mathrm{FeS}_{4}$ & 63.3 \\
\hline Tennantite & $\mathrm{Cu}_{12} \mathrm{As}_{4} \mathrm{~S}_{13}$ & 51.6 \\
\hline Enargite & $\mathrm{Cu}_{3}(\mathrm{As}, \mathrm{Sb}) \mathrm{S}_{4}$ & 48.3 \\
\hline Tetrahedrite & $\mathrm{Cu}_{12} \mathrm{Sb}_{4} \mathrm{~S}_{13}$ & 45.8 \\
\hline Chalcopyrite & $\mathrm{CuFeS}_{2}$ & 34.5 \\
\hline \multicolumn{3}{|c|}{ Oxide Minerals } \\
\hline Cuprite & $\mathrm{Cu}_{2} \mathrm{O}$ & 88.8 \\
\hline Tenorite & $\mathrm{CuO}$ & 79.9 \\
\hline Atacamite & $\mathrm{Cu}_{2} \mathrm{Cl}(\mathrm{OH})_{3}$ & 59.5 \\
\hline Malachite & $\mathrm{CuCO}_{3} \mathrm{Cu}(\mathrm{OH})_{2}$ & 57.3 \\
\hline Brochantite & $\mathrm{Cu}_{4} \mathrm{SO}_{4}(\mathrm{OH})_{6}$ & 56.2 \\
\hline Azurite & $2 \mathrm{CuCO}_{3} \mathrm{CU}(\mathrm{OH})_{2}$ & 55.1 \\
\hline Antlerite & $\mathrm{Cu}_{3} \mathrm{SO}_{4}(\mathrm{OH})_{4}$ & 54.0 \\
\hline Chrysocolla & $\mathrm{CuSiO}_{3} \cdot 2 \mathrm{H}_{2} \mathrm{O}$ & 36.0 \\
\hline
\end{tabular}

${ }^{36}$ Butts, Copper: The Science and Technology of the Metal, 22. 


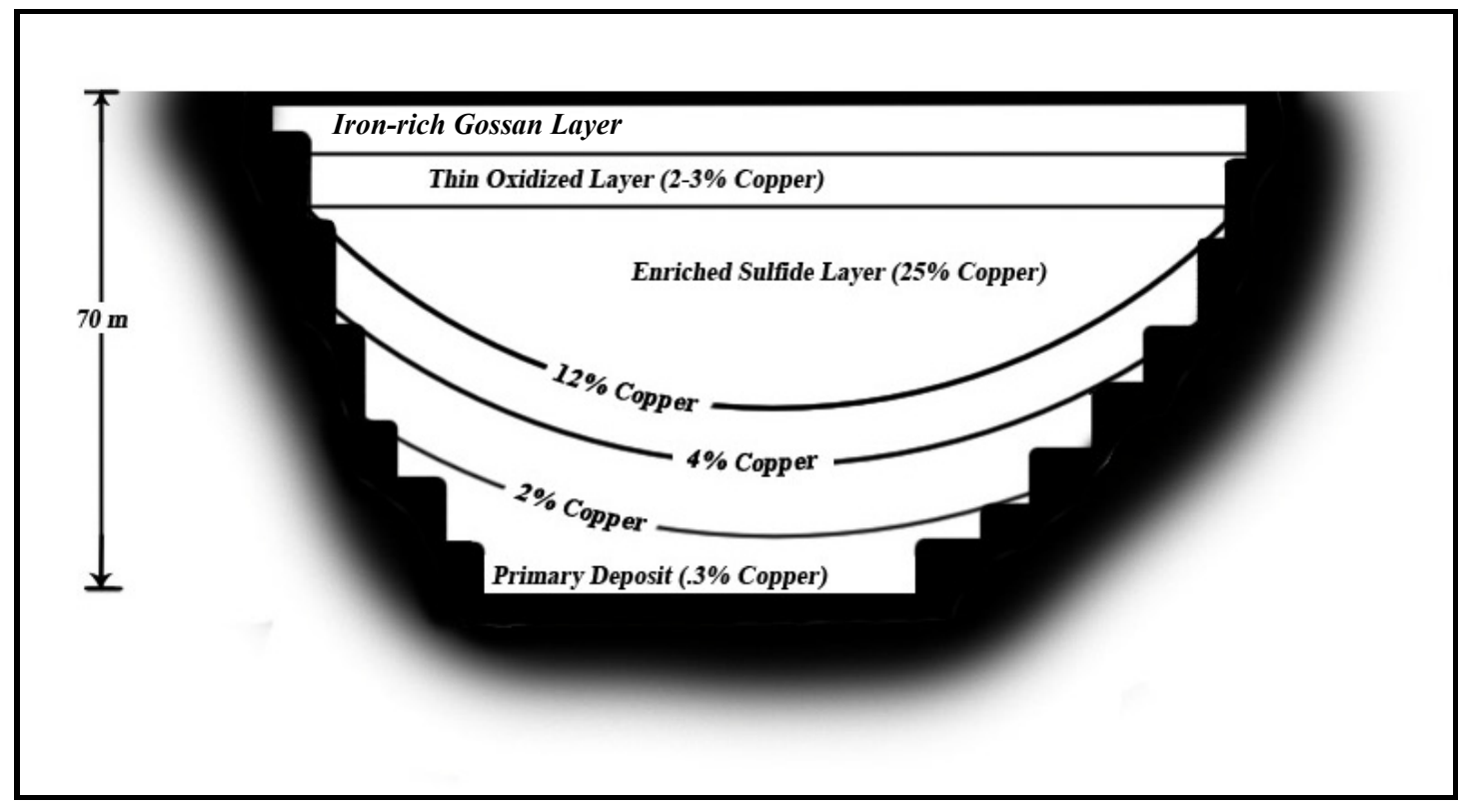

Figure 1.1 Typical Sulfide Deposit. Ergani Maden, Turkey. (After Tylecote 1976, 8)

and smelting to drive off contaminates and gangue materials. These processes sometimes required multiple steps and could take up to several weeks to complete.

With the exception of small deposits of native copper on the surface, such as glacially dislodged float copper, all copper minerals and ores needed to be mined or otherwise physically removed from the ground. These processes could be as simple as chiseling pieces off large exposed masses, as complex as hard rock underground mining, or as extensive as open pit mining very lean ores. Once above ground, the ores went through some form of concentrating to remove gangue and limit the waste material entering the smelter. Early, small-batch copper makers simply hand-removed the waste materials, while later more complex mills crushed or pulverized the ores and first used water and then, as techniques advanced, chemicals to separate the copper compounds. With the exception of a few $20^{\text {th }}$ century processes, all separated copper compounds were 
then subjected to extensive heat during smelting, to melt the mineral and remove gangue.

The smelting process usually required several basic steps, depending on ore type, and ultimately coalesced into two distinct smelting traditions based on either a blast furnace smelter, that mixed the ores directly with the fuel (discussed in Chapter 2), or a reverberatory smelter, that separated the fuel from the copper and directed, or reverberated, the heat from combustion over the pooled copper ore to melt it without cross contamination (discussed in Chapter 3).

\section{Native and Oxide Smelting}

Native copper from Lake Superior required relatively simple smelting. The large masses of pure copper were placed in removable-top reverberatory furnaces, melted, slagged, and drawn off into ingots or other useable shapes. As the dominant form of copper changed from large masses of pure native copper to ores, the smelting process changed as well. Michigan's pure amygdaloidal and conglomerate coppers were found in a gangue mixture where they comprised only $1-3 \%$ by weight. These coppers required a mechanical form of concentrating after mining, generally at a stamp mill. Then the concentrated materials, now $60-80 \%$ copper, were melted in a reverberatory furnace to avoid direct fuel contact, skimmed of slag, "rabbled" or paddle-mixed to induce the oxidation of any remaining impurities from the gangue, then "poled" by placing green hardwood into the molten copper to remove any remaining oxygen left from the rabbling. 
The oxygen combined with the wood's carbon to form carbon dioxide and was exhausted through the stack leaving pure copper to be drawn off into shapes or ingots. ${ }^{37}$

The general process for smelting oxide ores of copper was nearly as simple as the native copper process. Oxides, often of relatively high copper concentrations, were generally charged directly with a carboniferous fuel in a blast or stack furnace where the carbon atoms, freed during combustion, easily combined with the oxygen in the copper ore, resulting in an oxygen-free metal and carbon dioxide waste gas. Often smelters varied the mixture of ores charged into the furnace to achieve better results, such as adding self-fluxing rock to avoid the need for additional non-ore fluxes to form and draw off slag. ${ }^{38}$ Sulfide ores were occasionally used in the mix, likely in a reverberatory furnace, to create sulfur dioxide waste gases to encourage some oxygen removal, and metallic copper matte, an intermediate smelter product anywhere from $40-90 \%$ pure, that would then need further refining. ${ }^{39}$ The general formula for oxide reduction, in this case for tenorite, is:

$$
2 \mathrm{CuO}+\mathrm{C} \rightarrow 2 \mathrm{Cu}+\mathrm{CO}_{2}^{40}
$$

\section{Sulfide Smelting}

Native copper and oxides, however, were minority ores; sulfides were (and are) considerably more plentiful and have accounted for up to $90 \%$ of ores mined. The sulfides were also more complicated to smelt and generally served as the impetus for

\footnotetext{
${ }^{37}$ Henry D. Conant, "Copper-Smelting Practice in Lake Superior Region," Mining and Engineering World 35 (1911), 294.

${ }^{38}$ Edward Dyer Peters, Modern Copper Smelting (New York: The Scientific Publishing Co., 1898), 608.

${ }^{39}$ Hofman, Metallurgy of Copper, 245.

${ }^{40}$ Joan Day and R. F. Tylecote, The Industrial Revolution in Metals (London: The Institute of Metals, 1991), 133.
} 
most technological developments in copper metallurgy. ${ }^{41}$ Sulfur, in even small amounts, reduces the ductility of copper and increases its melting point, just the opposite of small amounts of tin. Because most copper ores contain significant amounts of sulfur, it became imperative to remove as much of it as possible. As a result, sulfide smelting evolved into a multi-stage process. Following concentration, sulfides ores were roasted to drive off the majority of the sulfur. Because sulfur is flammable, roasting was often a self perpetuating operation that ultimately ended on its own when most of the sulfur had been driven off as sulfur dioxide. Without additional heat to speed up the process, like the Welsh used in a reverberatory furnace, roasting the ore in open heaps, a hallmark of smelting for 5000 years, could take many weeks. ${ }^{42}$ The roasted ore was then melted, sometimes with fresh ore (as with oxide smelting) to facilitate waste removal, in a furnace to "fuse" the copper. Slag, made up of mostly gangue and other waste products, was skimmed off. This $40-90 \%$ pure, intermediate copper, referred to as "matte" or "regulus," and required a second, higher temperature firing in a furnace to further oxidize remaining waste products to produce a $95-99 \%$ pure copper called blister if it came from a reverberatory furnace or black if it came from a blast furnace. ${ }^{43}$ For most needs, this copper required a further refining step to increase the purity to $99.9 \%$ and eliminate the detrimental effects of other minerals on the copper.

\footnotetext{
${ }^{41}$ A. K. Biswas and W. G. Davenport, Extractive Metallurgy of Copper (New York: Pergamon Press, 1980), 1 .

${ }^{42}$ William Henry Greenwood, A Manual of Metallurgy (New York: G. P. Putnam's Sons, 1875), 57.

${ }^{43}$ Peters, Modern Copper Smelting, 224. This is a quite generalized version of the process which, prior to the industrial revolution, could require multiple roastings and intermediate smeltings prior to a series of refining smelts to purify the metal. In some cases, this process could take up to one year.
} 
During the initial roasting, some of the copper sulfides are converted to copper oxides when the sulfur is driven off:

$$
2 \mathrm{CuS}+3 \mathrm{O}_{2} \rightarrow 2 \mathrm{CuO}+2 \mathrm{SO}_{2}{ }^{44}
$$

These new oxides then combine with additional (fresh) sulfides, as described above, to form pure copper and more sulfur dioxide:

$$
2 \mathrm{Cu}_{2} \mathrm{O}+\mathrm{Cu}_{2} \mathrm{~S} \rightarrow 6 \mathrm{Cu}+\mathrm{SO}_{2}{ }^{45}
$$

As evident from these simple equations and Table 1.1, copious amounts of sulfur are often combined with copper in the sulfide ores. For nearly 5400 years, this element was permitted to drift off from the roasting process into the atmosphere. Sulfur dioxide smoke, when oxidized to form sulfur trioxide, condensed in the upper atmosphere and returned to the earth in the form of acid rain, often distributed over wide areas:

$$
\mathrm{SO}_{3}+\mathrm{H}_{2} \mathrm{O} \rightarrow \mathrm{H}_{2} \mathrm{SO}_{4} \text { (sulfuric acid) }
$$

By the late $19^{\text {th }}$ century, smelters had perfected the industrial recovery and oxidation of sulfur and its conversion into sulfuric acid. But sulfur recovery was not a universally accepted or desired practice for smelters until governments forced the issue and a market developed for sulfuric acid. Until then, blowing smoke and acid rain emanating from copper production destroyed crops, forests, and generally weakened surrounding ecosystems leading to some of the earliest environmental lawsuits. In addition to sulfur, arsenic and lead are common elements found in copper compounds, and mercury and acids are often combined in gangue or used in the smelting or refining processes. As

\footnotetext{
${ }^{44}$ Day and Tylecote, The Industrial Revolution in Metals, 133. These equations represent generalizations for a simple sulfide ore. Later, medieval- and industrial-period processes evolved to work complex chalcopyritic ores and will be discussed in Chapter 2.

${ }^{45}$ Ibid., 133.
} 
smelting got progressively more sophisticated and as ores got leaner, new material combinations and chemical processes were developed to ensure greater efficiency in copper recovery, often utilizing hazardous compounds that, after use, were often discarded into the local landscape.

In addition to smoke and chemical pollution, a portion of the copper escaped processing and ended up in concentrations posing a potential threat. Although copper ingestion was less probable, harmful, and lethal than lead historically, copper, in small doses is a necessary component of several bodily proteins. Copper deficiency in newborns can lead to death, but an excess of copper, called copper toxicosis, can lead to gastro-intestinal disruptions, epidermal reactions, or fatal liver disease. ${ }^{46}$

The more dangerous by-products of copper smelting, however, were, as mentioned above, the atmospheric distribution of sulfur-heavy smoke from the roasting and smelting processes leading to respiratory ailments, some cancers, and extensive environmental degradation, and the release of lead, arsenic, and mercury, each a lethal neurological or carcinogenic toxins.

\footnotetext{
${ }^{46}$ I. Herbert Scheinberg, "Human Health Effects of Copper," in Copper in the Environment, ed. Jerome O. Nriagu (New York: John Wiley and Sons, 1979), 19 and 25.
} 


\section{CHAPTER 2. A SHORT HISTORY OF COPPER SMELTING THROUGH 1640}

In that remote age when man was unacquainted with metals, and his implements and weapons were fashioned of wood, of stone, and of bone, he has been regarded as a mere savage, scarcely, if at all, removed in intelligence from the wild animals with which he had to contend; and although this may perhaps be near the truth as regards the man of early Paleolithic times, it is hardly a fair designation for the man of the later stages of the Neolithic period, notwithstanding that even he had made but little advance in what are termed the civilized arts...Such were the men who were the first rude metallurgists. ${ }^{47}$

-W. Gowland, 1912 (“Copper and Its Alloys in Early Times," 11)

Four significant events in the early development of metallurgy first occurred in and around southwest Asia and likely spread throughout the Eastern Hemisphere. Some of these developments, but not all, also occurred independently, but later, in the Western Hemisphere. The first was the recognition that metals, especially copper, which, in pure native form is estimated at 200 times more prevalent in the earth's crust than native gold and 625 times more prevalent than native silver, held specific advantages for lithic-based societies. ${ }^{48}$ While native coppers were not necessarily stronger or sharper than the stone tools and weapons they would eventually replace, they were malleable and shapeable with stone hammers and, with repeated heat treating, hammering, and quenching, could be worked and reworked into useful implements with relatively tough edges. The adoption of native copper occurred at different times in different regions, but it is likely

\footnotetext{
${ }^{47}$ W. Gowland, "Copper and Its Alloys in Early Times," Journal of the Institute of Metals 7 (1912), 11.

${ }^{48}$ Clair C. Patterson, "Native Copper, Silver, and Gold Accessible to Early Metallurgists," American Antiquity 36, no. 3 (1971), 297. These values do not take into consideration Lake Superior native coppers which did not lead to a smelting tradition until the 1840s and, of course, were not available to Near Eastern metallurgists. Considering all available copper in the earth's crust, according to Patterson, native copper would be around 12,000 times more prevalent than gold and 5000 times more prevalent than silver.
} 
that Africa, southwest Asia, China, Russia, and North and South America each adopted metal use independently. ${ }^{49}$

The second major step and likely one of the most significant developments for early civilizations was the innovation of smelting and the extrication of metallic copper from ore. The first smelters occurred in southwest Asia and, over two thousand years, likely diffused along trade networks across the Mediterranean, Europe, Africa, and East Asia. While scholars debate the trade routes used for the diffusion of metallurgy and argue whether or not China, Africa, and Europe separately developed smelting at about the same time as or shortly after Southwest Asia, archaeological evidence clearly suggests that pre-colonial South America did develop an independent smelting tradition, but that North America, home to the world's largest deposits of native copper and a cold working and annealing tradition, did not. ${ }^{50}$

The third step was the addition of alloying elements, initially accidental, that significantly increased the hardness and reduced the brittleness of copper to make the metal considerably more useful than stone or pure copper for tools, weapons, hardware, and implements. The first arsenical copper alloys and tin-bronzes produced systematically in large quantities likely came out of the Middle East but spread quickly throughout the rest of the Eastern Hemisphere. Interestingly, China and the British Isles with rich copper and tin deposits probably skipped a copper age altogether and, when

\footnotetext{
${ }^{49}$ R. F. Tylecote, A History of Metallurgy, 1st ed. (London: Institute of Metals, 1976), 2, and William Gowland, "The Metals in Antiquity," Journal of the Royal Anthropological Institute of Great Britain and Ireland 42 (1912), 236.

${ }^{50}$ See Paul T. Craddock, Early Metal Mining and Production (Washington, D.C.: Smithsonian Institution Press, 1995), and Robert Raymond, Out of the Fiery Furnace: The Impact of Metals on the History of Mankind (University Park: Pennsylvania State University Press, 1986).
} 
smelting technology finally reached there, went directly into a bronze age. ${ }^{51}$

Archaeological evidence suggests that South America also reached a bronze age before Spanish colonization, but, unlike Europe, Asia, and Africa, would not develop an iron age prior to contact.

The fourth step was the development of sulfide ore smelting. With this innovation, copper smelting grew considerably more complex, requiring multiple preparatory steps before charging a furnace, but the development, as shown in Chapter 1, also significantly increased the amount of copper available to ancient societies. With much more widespread metallurgical activities, increased weapons production, and elaborate economic systems based on trade, civilizations grew more powerful and wealthy, ultimately contributing to the formation of kingdoms and empires.

\section{Early Smelting}

Copper smelting's exact origins are a mystery. Some late $19^{\text {th }}$ - and early $20^{\text {th }}-$ century British metallurgists insisted that metal smelting began accidently in a campfire ringed with copper oxides and went so far as to give the dimensions of that first fire. Others stipulated that the campfire had to be located on a hill or used on a very windy day to take advantage of increased air velocity. ${ }^{52}$ More practical scholars, however, argued that even wind-blown hillside campfires could not produce enough heat to reduce copper from ore. ${ }^{53}$ The more likely "accidental" discovery scenario placed the location at a

\footnotetext{
${ }^{51}$ Tylecote, A History of Metallurgy, 25-26; Gowland, "The Metals in Antiquity," 252.

${ }^{52}$ Gowland, "Copper and Its Alloys in Early Times," 24.

${ }^{53}$ H. H. Coghlan, "Some Experiments on the Origin of Early Copper," Man 39, July (1939), 106.
} 
pottery. Kilns, which had been around longer than smelters and operated with a similar flue-draft as reverberatory furnaces would, generated enough heat under the right conditions to fuse clay and melt certain stone types. Since powdered copper oxide glazes were prized for their blue coloration, the first copper was likely reduced from an excess of glaze at a pottery or from experimentation after the probably kiln-discovery of metallic lead, whose oxides were also used for glazing material and reduced at a significantly lower temperature than copper oxides. ${ }^{54}$

Many metal historians place the origins of copper smelting in the $6^{\text {th }}$ millennium BCE in Anatolia (modern Turkey) or neighboring Iran based on scattered archaeologically dated slags. Although the scale of production at these sites strongly suggests some form of organized metallurgical activity, these remains cannot be conclusively associated with smelting because the slags could have resulted from a native-copper melting process, and no associated furnaces or artifactual evidence have been documented from that period. The earliest undisputed evidence dates the birth of smelting to sometime prior to 3500 BCE. ${ }^{55}$ Analyses of copper artifacts from this period reveal certain chemical compounds that could only be created through an orereduction process. Further complicating the temporal origins of metallurgy, no complete remains of a smelting furnace are found before the Egyptian "New Kingdom" period from the $14^{\text {th }}$ to $12^{\text {th }}$ centuries BCE. By this time, however, the Eurasian trade networks had spread copper smelting across much of Europe and China. ${ }^{56}$

\footnotetext{
${ }^{54}$ Ibid., 197.

${ }^{55}$ Tylecote, A History of Metallurgy, 5.

${ }^{56}$ Ibid., 29.
} 


\section{Early Metallurgy}

Copper as a pure metal is generally too soft for practical tool making and weapon use and tended to be employed initially for ornamentation or simple implements, such as pins, that did not require high-strength. The primary means to modify the form of pure copper, hammering with stone tools, often caused brittleness, resulting in a weak structure and ultimately an unusable edge. Early metallurgists in the Middle East, and independently in North and South America, however, soon discovered that the combination of hammering and annealing increased copper's characteristic hardness. ${ }^{57}$ Annealing, a practice in wide use today, involved the slow heating of a metal to a specific temperature range that reduced or "relaxed" the stresses inherent in a hammered metal's surface. These steps produced a stronger material which, following repeated hammering and annealing, could be worked into functional tools or weapons with much more durable edges and would not fail as easily under high impacts.

Despite the advances made in working pure copper, its hardness and durability was still lower than some stone tools. In the Eastern Hemisphere, however, pure copper was replaced by copper produced from arsenic-contaminated ore as early as $3500 \mathrm{BCE}$. Copper Age smelters learned through trial and error that certain ore-types produced a superior final metal even if they were not exactly sure why. These arsenic "contaminated" coppers, referred to as arsenical copper or sometimes arsenical bronze,

\footnotetext{
${ }^{57}$ Frank Hamilton Cushing, "Primitive Copper Working: An Experimental Study," American Anthropologist 7, no. 1 (1894), 94; Susan R. Martin, Wonderful Power : The Story of Ancient Copper Working in the Lake Superior Basin, Great Lakes Books (Detroit: Wayne State University Press, 1999), 123.
} 
could be hardened with stone hammers faster and remained stronger than pure annealed copper, resulting in even tougher and less brittle edges. ${ }^{58}$

As copper's importance increased, techniques of smelting and metal working spread. One key feature of the early metal trade was the advent of the crucible furnace to remelt copper ingots. Copper workers took raw standardized ingots - the direct, relatively pure product of the smelters - and placed them in ceramic crucibles (bowls). They either covered the crucibles with charcoal in a furnace or placed them in an open charcoal mound to melt the copper under a blast. ${ }^{59}$ While this was not a significant technological departure from smelting furnaces, it was a notable event because it created a two-step process and, with large crucibles, ultimately led to a means for melting and casting greater volumes of molten metal than a single smelter heat produced. Later metal workers used the process (or a similar one) to create specific alloys or recover precious metals found in many copper ores. The key trade-advantage was that these simple crucible furnaces could be built anywhere fuel was available, allowing smelter-produced ingots to be shipped/traded from copper mining regions to nearly any other location, thereby expanding trade and ultimately leading to the earliest metallic currency: standardized copper ingots.

The next major change in copper production, and arguably the most important to date, occurred with the combination of tin and copper to produce bronze. The addition of small amounts of tin more than doubled the hardness and strength of pure copper while lowering its melting point, making the alloy much more advantageous for working and

\footnotetext{
${ }^{58}$ Tylecote, A History of Metallurgy, 6.

${ }^{59}$ Ibid., 18. Ingots, as referred to here, are the relatively pure-copper product of smelting furnaces.
} 
casting. ${ }^{60}$ Many late- $19^{\text {th }}$-century metallurgists and anthropologists simply assumed that tin was a similar, albeit rarer, copper ore contaminant as arsenic. Later archaeologists, however, found little evidence of tin-contaminated ore in the Middle East. ${ }^{61}$ The major tin deposits available in the Bronze Age were located in Italy, Bohemia, Saxony, Malaya, Nigeria, China, and Cornwall, while South America had deposits in Bolivia. Evidence suggested that early bronzes were mostly arsenical alloys containing minute amounts of tin, possibly the result of trace tin-contamination. True high-tin bronzes, containing 7$10 \%$ tin, which indicate an intentionally created alloy, did not occur until the advent of extensive Mediterranean Sea and Danube River trade networks after 3000 BCE. Tylecote, Childe, and, to a lesser extent, Dayton suggested that these first, high-tin bronzes likely occurred as a result of copper-age smelting spreading to Saxony or Cornwall where both copper and tin deposits occur. While they differ on the origin, all three believe that early European metallurgists developed the first bronzes and then brought the technique to the Near East when the Europeans began trading tin. ${ }^{62}$ With the growth of tin-alloyed bronze production, arsenical coppers slowly disappeared because changes in smelting techniques required to make high-tin bronze tended to oxidize the more volatile arsenic early in the process.

\footnotetext{
${ }^{60}$ See Appendix A for comparative strength details.

${ }^{61}$ Ibid., 14; Gowland, "The Metals in Antiquity," 239.

${ }^{62}$ Tylecote, A History of Metallurgy, 14; V. Gordon Childe, "The Danube Thoroughfare and the Beginning of Civilization in Europe," Antiquity 1, no. 1 (1927), 90; J. E. Dayton, "The Problem of Tin in the Ancient World," World Archaeology 3, no. 1 (1971), 61.
} 


\section{Early Furnaces}

By the time the first complete smelting furnaces appear in the archaeological record between the $14^{\text {th }}$ and $12^{\text {th }}$ centuries BCE, smelting technology had been evolving for several millennia, the smelting process had been somewhat standardized with similar furnaces and ingot shapes occurring throughout the Eastern Hemisphere, and bronze had been in wide use for over a thousand years. The earliest Bronze Age furnaces were generally short, cylindrical shafts roughly two feet tall and two feet in diameter with a hemispherical-concave floor, a single tuyere (forced-air nozzle) opening in the furnace wall near the bottom, and a slag hole off the front. ${ }^{63}$ A bellows, likely an animal-skin bag or pot, forced air through the tuyere into a charcoal fire in the shaft, and generated enough heat to melt the copper ores mixed with the charcoal. Metal workers then tapped the slag, the lighter non-copper waste by-product, at various times during the heat while the molten copper settled into the furnace floor. (See Figures 2.1 and 2.2) When cooled, the metal solidified into a plano-concave ingot, typically $20-30 \mathrm{~cm}(8-12$ inches $)$ wide and around $3.8 \mathrm{~cm}$ (1.5 inches) thick, weighing about $6 \mathrm{~kg}(13.2 \mathrm{lbs}){ }^{64}$ This general shape and size eventually became a standard trade currency leading to the advent of coins. $^{65}$ (See Figure 2.3)

By 1500 BCE, Bronze Age smelters, in an early and significant process innovation, were tapping molten copper out the front of the furnace. This new technique offered greater efficiency and fuel savings because the furnace did not have to be cooled

\footnotetext{
${ }^{63}$ Tylecote, A History of Metallurgy, 29

${ }^{64}$ W. Gowland, "Presidential Address: Copper and Its Alloys in Prehistoric Times," The Journal of the Anthropological Institute of Great Britain and Ireland 36, Jan-June (1906), 18; Tylecote, A History of Metallurgy, 30.

${ }^{65}$ Tylecote, A History of Metallurgy, 29 and 31.
} 


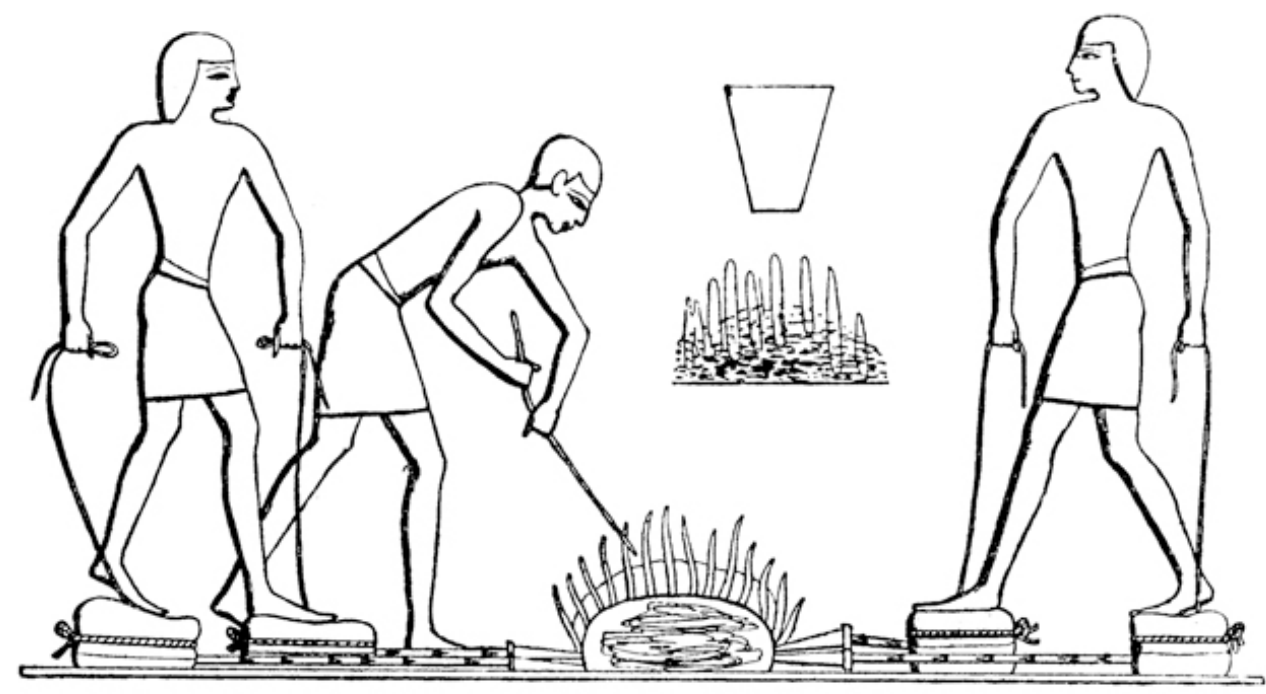

Figure 2.1 Early smelter demonstrating skin-bag bellows. (After Gowland 1906, 15)

to remove an ingot from the inside. Further, the furnace lining remained intact and the furnace could be recharged with ore much quicker, approaching a near continuous operation and considerably increasing productivity. Tapping molten copper from the furnace into an external ingot-mold ultimately led to a second standard ingot shape, the larger, 30-40 kg (65-85 lbs) “ox-hide.” (See Figure 2.4)

Whether smelting had several points of near simultaneous invention or a single inventor and multiple diffusers, the process had spread across Europe and Asia by the $2^{\text {nd }}$ millennium BCE, leading to expanding demand and pressure on known copper oxide and tin ore deposits and a significant increase in cost of bronze. To alleviate some of the growing supply problems, early metallurgists developed new alloys based on specific properties needed for specific items. Weapons and tools, for example, required the strength and durability of bronze, but cast artwork, coins, and some implements could use softer, less expensive alloys. Lead, a soft, easily-smelted and highly prized material 




Figure 2.2 Side view of "New Kingdom" era smelter demonstrating an air-blast tuyere and the origination of the plano-concave ingot created when molten copper settled in the furnace base. Not shown here is the notch for drawing off molten slag, although slag removal was not necessary to create a plano-concave ingot. The glassy, hardened slag could simply be chipped off the ingot top after the ingot was removed and cooled. (After Rothenberg 1990, 39)



Figure 2.3 Comparison between a typical early Bronze Age plano-concave ingot (left) and a typical late Bronze Age ox-hide ingot (right). (After Tylecote 1976, 31, and Bass 1961, 87.) 


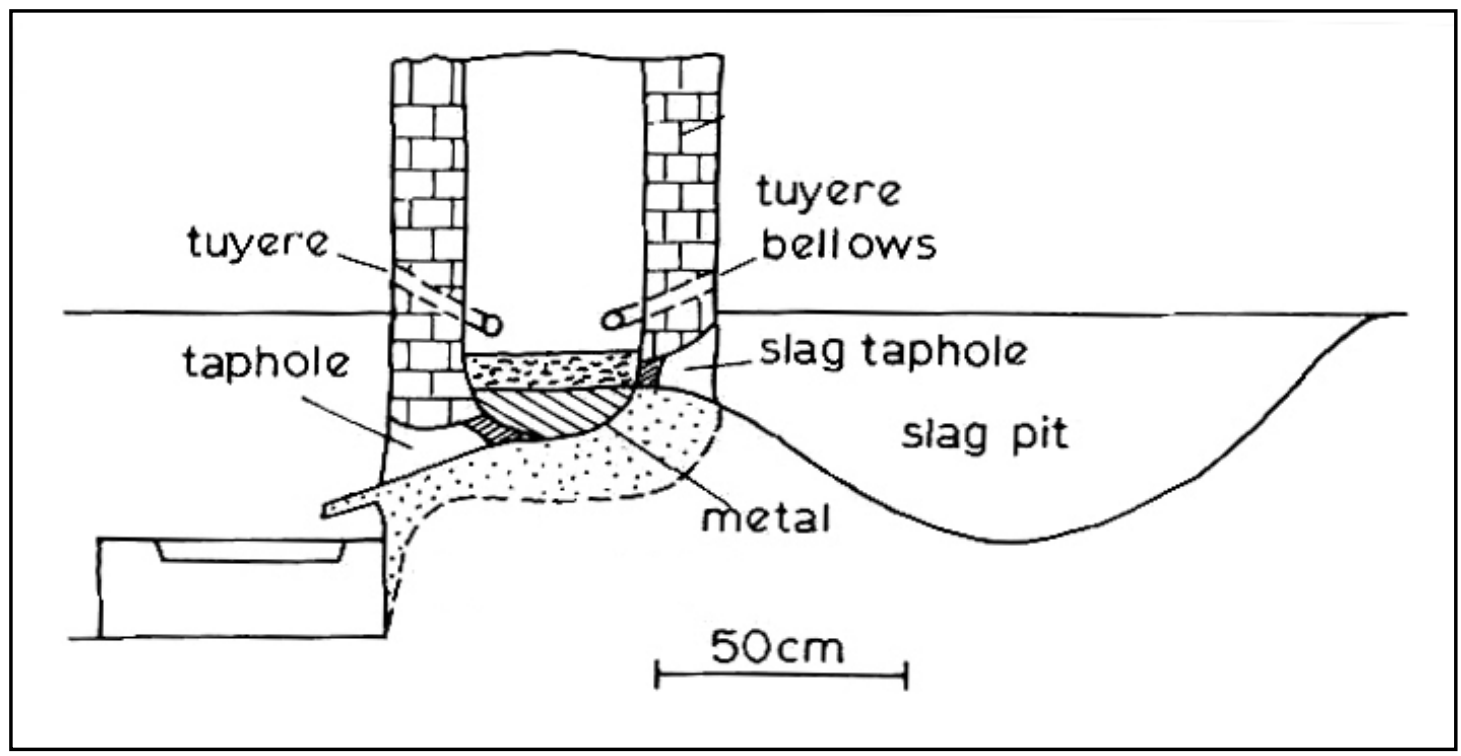

Figure 2.4 Typical late Bronze Age and Roman era smelting furnace capable of producing an ox-hide ingot. Note separate slag and metal tap holes. (After Tylecote 1976, 21)

produced in greater amounts than all other non-ferrous metals combined through the $19^{\text {th }}$ century AD, became a key component of emerging metal technologies. In addition to its eventual use in architectural, plumbing, and household vessels, it found its way into cast bronze artwork, which often had high lead concentrations. Coins, too, were often bronzelead or leaded bronze-gold alloys. ${ }^{66}$ In a similar fashion centuries later, Romans reacting to the high price of tin significantly expanded production of the copper-zinc alloy, brass, which produced a softer alloy than bronze and was used mostly for growing coin production and mirrors. ${ }^{67}$

The next significant development was the shift to sulfide ores. As shown in Figure 1.1, an enriched layer of copper sulfide often existed below oxide layers of typical

${ }^{66}$ J. H. Gladstone, "On the Transition from the Use of Copper to That of Bronze," The Journal of the Anthropological Institute of Great Britain and Ireland 26 (1897), 313; Gowland, "Presidential Address: Copper and Its Alloys in Prehistoric Times," 40.

${ }^{67}$ Gowland, "Presidential Address: Copper and Its Alloys in Prehistoric Times," 32. 
deposits. While the first copper sulfide use is as undateable as the origin of smelting, Austrian and Irish archaeological sites from 1200 BCE and southwest Asian sites as early as $2500 \mathrm{BCE}$ demonstrate clear evidence of roasting, a necessary component of sulfide ore processing. ${ }^{68}$ Since many copper ore deposits have been worked for centuries, however, it is unclear exactly when early miners reached sulfide layers. Nonetheless, the advent of sulfide ore smelting does not seem to be treated with much reverence in historical accounts of the early metal age despite its importance in significantly increasing the availability of copper. Patterson, for one, simply suggests that the growth of empires around $3000 \mathrm{BCE}$ required a significant increase in the production of weapons and tools and that bronze production expanded equally. This growth eventually consumed known deposits of easily smelted oxide ores, exposing the more complex, albeit richer, sulfide deposits below. ${ }^{69}$

By the start of the Iron Age (1500-1000 BCE), the key components of copper sulfide smelting and working had been established: mining-roasting-smelting and alloying, casting, and working. But iron's vast availability, ease of smelting, and key strength properties saw it replace copper and bronze for many items, primarily hammered weapons, tools, and hardware. Early ironmasters, however, could not reach iron's melting point and for most castings, especially sculpture, copper alloys still dominated.

\footnotetext{
${ }^{68}$ Tylecote, A History of Metallurgy, 29; Patterson, "Native Copper, Silver, and Gold Accessible to Early Metallurgists," 286.

${ }^{69}$ Patterson, "Native Copper, Silver, and Gold Accessible to Early Metallurgists," 310.
} 


\section{Trade and Empire}

Trade and empire-building played key roles in the evolution and diffusion of copper smelting technology from its inception through the Middle Ages. Extensive trade networks developed in the ancient world, supplying regions poor in some products and raw materials from richer regions in exchange for other goods and materials. Copper-rich regions traded for tin and other alloying ingredients and exported copper, bronze, and eventually brass throughout the Eastern Hemisphere. Like many other trade-goods, copper ingots evolved into currency which, like precious metals, eventually developed into coins. Trading cultures likely first used the Mediterranean Sea but later ventured up the Danube River, exploring and prospecting for minerals to feed growing demand. The Danube, according to Childe and Dayton, became a key throughway to Central Europe after Ice Age glacial barriers retreated in the early Bronze Age, opening easy overland routes to Europe from the Near East. Several writers, including Dayton and Childe, argue that the Eastern metallurgists took copper smelting up the Danube and there developed the first bronzes sometime after $3000 \mathrm{BCE} .{ }^{70}$ While the origin of tin in the first bronzes is debated, tin ores in Saxony and Bohemia proved significant during the Bronze Age.

Coinciding with the growth of trade, increasing populations, and stronger metallic weaponry, regions began to organize politically and dominate neighboring regions, ultimately leading to the formation of kingdoms, then empires. With the growth of

\footnotetext{
${ }^{70}$ Dayton, "The Problem of Tin in the Ancient World," 61; V. Gordon Childe, "The Danube Thoroughfare and the Beginning of Civilization in Europe," 81. While both writers agree that non-Europeans developed the first high-tin bronzes from European tin, they differ on the origin of the non-Europeans.
} 
empires, the need for metals expanded dramatically. While the Egyptians, Trojans, Phoenicians, and Greeks each increased the world's demand for copper and bronze, the extensive military, civilian, and political organization of the Roman Empire raised demand for copper and other metals to a scale never before reached and not to be seen again for nearly 800 years. The growth of the Roman Empire caused a substantial expansion of the organization and production of metal extraction and working, including a substantial increase in zinc, tin, copper, lead, iron, bronze, and brass use. ${ }^{71}$ In addition to Italian, Cypriot, and Middle Eastern mines, the Romans opened or expanded extensive mineral deposits in Rio Tinto (Spain), Germany, Hungry, and Cornwall (United Kingdom). The Romans used copper alloys for general construction, adornment, and art, and to supplement iron and steel weapons and armor and, in significant amounts, in coins. $^{72}$ One "tentative" estimate is that the total copper produced by the Romans between $250 \mathrm{BCE}$ and $350 \mathrm{CE}$ represented close to $10 \%$ of all the copper produced from the dawn of the copper age through $1900 .^{73}$

\section{Early Environmental Degradation}

With the great expansion of empire and metal works came environmental consequences and landscape degradation, some of which were recognized at the time.

\footnotetext{
${ }^{71}$ Andrew Wilson, "Machines, Power, and the Ancient Economy," The Journal of Roman Studies 92 (2002), 17.

${ }^{72}$ Tylecote, A History of Metallurgy, 53.

${ }^{73}$ S. Hong et al., "A Reconstruction of Changes in Copper Production and Copper Emissions to the Atmosphere During the Past 7000 Years," The Science of the Total Environment 188, no. 2-3 (1996), 185. This estimate carries a rather large margin of error. The authors refer to their conclusions as "tentative" and their data, which were developed using secondary sources suggesting copper production based on slag waste at Roman sites and the author's own research into copper pollution recorded in Greenland ice, as merely "approximations."
} 
The most obvious change related to deforestation. Mining and smelting activities required considerable quantities of wood for roasting, furnace fuel, and mine-timbering. One scholar estimated that given the amount of slag on Cyprus, metal production was capable of completely deforesting the island 16 times over a 3500 year period. ${ }^{74}$ Based on Rio Tinto slags, another scholar estimated a total timber requirement of 100 million tons for charcoal production alone over the course of ancient and Roman mining. ${ }^{75}$ Another more recent study examined the toxic effluent of mining and smelting in the Rio Tinto estuary over 5000 years. This study concluded that elevated levels of copper and zinc already existed in water and sediments more than 2000 years before large-scale $19^{\text {th }}$ and $20^{\text {th }}$ century open-pit mining. Oysters and clams, they found, survived amid these toxic conditions, suggesting a direct link between mining contaminants and human intake. $^{76}$ Similar studies have been conducted in Tuscany, examining unusually high arsenic levels near mining and smelting sites (discussed below), and in Jordan and Cyprus, tracking the bio-accumulation of 5000 years of copper and lead production. ${ }^{77}$

\footnotetext{
${ }^{74}$ Michael Rice Jones, "Oxhide Ingots, Copper Production, and the Mediterranean Trade in Copper and Other Materials in the Bronze Age" (MS. Thesis, Texas A\&M, 2007), 128. As summarized by Jones, the chief criticism of this account is the word "deforestation." The critics claim that some sort of woodland management was paramount to sustain works for so long and that the island was likely never completely deforested. None, however, seem to be arguing against the copious amounts of wood consumed given the amount of slag.

${ }^{75}$ Craddock, Early Metal Mining and Production, 194.

${ }^{76}$ R. A. Davis Jr et al., "Rio Tinto Esturary (Spain): 5000 Years of Pollution," Environmental Geology 39, no. 10 (2000), 1115.

${ }^{77}$ See Andreal Manasse and Marcello Mellini, "Chemical and Textural Characterisation of Medieval Slags from the Massa Marittima Smelting Sites (Tuscany, Italy)," Journal of Cultural Heritage 3, (2002), 187206; J. P. Grattan, D. D. Gilbertson, and C. O. Hunt, "The Local and Global Dimensions of Metalliferous Pollution Derived from a Reconstruction of an Eight Thousand Year Record of Copper Smelting and Mining at a Desert-Mountain Frontier in Southern Jordan," Journal of Archaeological Science 34, no. 1 (2007), 83-110; F. B. Pyatt et al., "The Heavy Metal Content of Skeletons from an Ancient Metalliferous Polluted Area in Southern Jordan with Particular Reference to Bioaccumulation and Human Health,"
} 
The more serious and pressing environmental problem of metal production, however, was not mining but the pervasive smoke emanating from smelting works. Early copper and bronze works used open roasting and smelting processes that, prior to the $20^{\text {th }}$ century, lost up to 15 percent of its metal. ${ }^{78}$ This copper tended to be vaporized and dispersed into the atmosphere with little immediate effect on human heath, but long-term soil contamination and bioaccumulation posed more significant lingering problems. ${ }^{79}$ The effects of sulfur smoke from open roasting and smelting processes should have created critical concerns for people living near metal works. While sulfur-specific criticism does not enter the written record until the second millennium AD, early writers did complain about the dangers of mining and smelting related-air pollution in general. Nriagu, for instance, noted that Xenophon and Lucretius observed the noxious emissions from metal mines in Greece, and that Pliny declared that smelter emissions were dangerous to animals, especially dogs. ${ }^{80}$ While these examples are not specific to copper, all metal working, including precious metals, iron, lead, and copper contributed to a Roman edict forbidding metal works in the city because of unhealthy emissions. These conditions ultimately led to the oft quoted Roman law, "Aerem corrupere non licet" or "polluting air is not allowed." 81

Ecotoxicology and Environmental Safety 60, no. 3 (2005), 295-300; and F. B. Pyatt, "Copper and Lead Bioaccumulation by Acacia Retinoides and Eucalyptus Torquata in Sites Contaminated as a Consequence of Extensive Ancient Mining Activities in Cyprus," Ecotoxicology and Environmental Safety 50, no. 1 (2001), 60-64.

${ }^{78}$ Hong et al., "A Reconstruction of Changes in Copper Production and Copper Emissions to the Atmosphere During the Past 7000 Years," 248.

${ }^{79}$ See Pyatt, "Copper and Lead Bioaccumulation," (2001), 60-64.

${ }^{80}$ Jerome O. Nriagu, "Global Metal Pollution: Poisoning the Biosphere," Environment 32, no. 7 (1990), 8.

${ }^{81}$ E. Borsos et al., "Anthropogenic Air Pollution in Ancient Times," ACTA Climatologica Et Chorologica (Universitatis Szegediensis, Szeged, Hungary: Universitatis Szegediensis, 2003), 8. 
The Roman Empire provided the highest expression of metal working to date. Copper, bronze, brass, lead, and eventually iron all reached peaks of efficiency and production. Following the fall of Rome, however, the western world slipped into the dark ages and smelting declined. The Rio Tinto mines, for example, had produced copper, gold, silver, lead, and tin for nearly 3000 years before Spain fell to the Visigoths in the $5^{\text {th }}$ century CE. The Visigoths likely used central European mines for metals, leaving the Rio Tinto sites abandoned and unworked. ${ }^{82}$ Similarly, Italian and Cypriot copper mines and works saw production declines and stoppages following the fall of the empire. ${ }^{83}$ Coins, an important use for non-ferrous metals, provide further evidence of a significant drop in copper production because Roman coins continued in circulation for hundreds of years following the empire's decline before new European states began minting their own. ${ }^{84}$

Following the fall of the Roman Empire, Western copper production declined significantly, but in the East, Chinese dynasties grew more powerful and increased copper production through the first millennium, dominating world metal production. China's earliest copper works date to 2500-2000 BCE, possibly the result of trade routes through Russia to southwest Asia. Like Saxony and Cornwall, China had tin deposits quite close to copper deposits, and when smelting developed there, China jumped right into a Bronze Age. Tylecote suggests that China's great advances in metallurgy, such as the first blast furnaces and water-powered bellows, supported the growth of its dynasties

\footnotetext{
${ }^{82}$ F. R. Morral, "A Mini-History of the Rio Tinto (Spain) Region," CIM Bulletin 83, no. 935 (1990), 150.

${ }^{83}$ Mellini and Marcello, "Chemical and Textural Characterisation of Medieval Slags," 187.

${ }^{84}$ Tylecote, A History of Metallurgy, 59.
} 
and empires and eventually spread to Europe ${ }^{85}$ Like Rome, demand for metals grew with large-scale political organization, and China's metallurgists responded with significant advances. ${ }^{86}$ China's output levels during the Sung Dynasty in the $9^{\text {th }}$ century had been unequaled since the first century BCE. But the Mongol invasions of the $14^{\text {th }}$ century eroded the empire, discontinued coin usage, and with it, large-scale production of metals. $^{87}$

\section{The German Method}

Despite the decline in Roman copper production and the abandonment of sites in Spain, Tuscany, and Cyprus, many copper mining and smelting operations likely continued to produce metal, albeit on a lesser scale, during the migration period. The dominant European political groups in the mid and late first millennium were Germanic and Slavic tribes from Central and Eastern Europe, and Moors from southwest Asia and Africa. Not empire builders like the Romans were, these groups at first were more transient and migratory. Even after their populations grew, stabilized, and became more settled, they tended to control much smaller territorial areas than Rome.

From the fall of Rome until the resumption of large-scale metal production in the late medieval period, little, according to Tylecote, is known about non-ferrous metallurgy ${ }^{88}$ Although it is unclear exactly where migration-period cultures obtained their metals, by the turn of the first millennium CE, Germany had clearly begun

\footnotetext{
${ }^{85}$ Ibid., 70.

${ }^{86}$ Ibid., 36.

${ }^{87}$ Martin Lynch, Mining in World History (London: Reaktion, 2002), 14.

${ }^{88}$ Tylecote, A History of Metallurgy, 69
} 
dominating Western mining and metallurgy. Whether or not the Bronze and Iron Age Bohemian and Saxon mines continued to be worked immediately after the fall of Rome is unclear, but by the $9^{\text {th }}$ and $10^{\text {th }}$ century significant non-ferrous ore bodies were worked in the region.

These new mines soon altered the course of German metallurgy. Lodes in both Saxony's Harz Mountain and the Saxon/Bohemian Freiberg region were primarily silver, but also contained significant copper, tin, and lead. ${ }^{89}$ Much of the silver and copper from these regions was converted into currency that, some suggest, contributed directly to the financing of the Renaissance. ${ }^{90}$ Demand for metals was so high beginning around $1000 \mathrm{CE}$, and the German lodes so rich, that miners and metallurgists overcame such significant production obstacles as dewatering mines and separating the rich mix of metals from their complex ores. Ultimately, these developments led to the emergence of new metallurgical and mining techniques and the diffusion of German practices between 1000 and 1220 AD to new copper mines and smelters in Tuscany, Sweden, Hungary, and several Saxon/Bohemian areas. ${ }^{91}$

The German or Continental Method of copper smelting named to distinguish the process from later Welsh Methods, likely evolved between 1000 and $1220 \mathrm{CE}$ from a concentration of mining and smelting activities in the mountains around Saxony linked to significant copper and bronze production centers. Technologically, roasting, as discussed in Chapter 1, remained an open-air process, and the smelters largely resembled the

\footnotetext{
${ }^{89}$ Raymond, Out of the Fiery Furnace: The Impact of Metals on the History of Mankind, 98-99.

${ }^{90}$ Ibid., 102.

${ }^{91}$ Tylecote, A History of Metallurgy, 69-70.
} 
furnaces used by the Romans with few significant changes other than an increased stack height and masonry construction. ${ }^{92}$ (See Figures 2.4, 2.5, and 2.6)

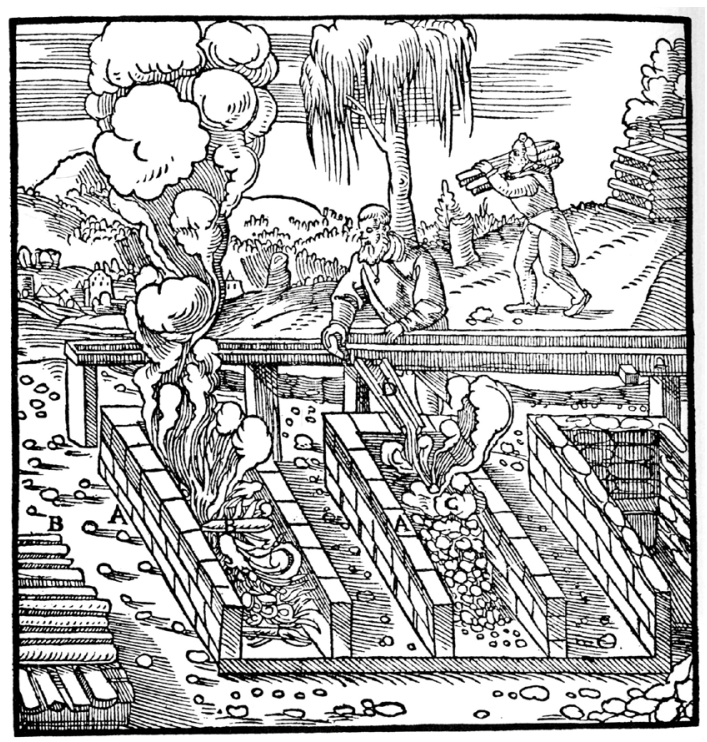

Figure 2.5 German multiple-bin ore roasting ca. 1550. (After Agricola ${ }^{93} 1950,350$ )

While the physical components remained the same, just an order of scale larger, key aspects of the overall process evolved dramatically. Newly formed kingdoms, some perpetually short on cash, strove to maximize mining, especially of metals that could be turned into coin. ${ }^{94}$ Metallurgists developed more efficient processes to retrieve recoverable amounts of precious or useful base metals (that could also be significant wealth generators), to minimize copper lost to slag and waste materials, and to further purify copper leading to better performing final alloys.

\footnotetext{
${ }^{92}$ Craddock, Early Metal Mining and Production, 172, and Tylecote, A History of Metallurgy, 93. Tylecote states that these furnaces were merely adaptations of Roman iron furnaces.

${ }^{93}$ Hoover Translation of Agricola, Georgius. De re metallica. (New York: Dover Publications, 1950).

${ }^{94}$ Lynch, Mining in World History, 30.
} 


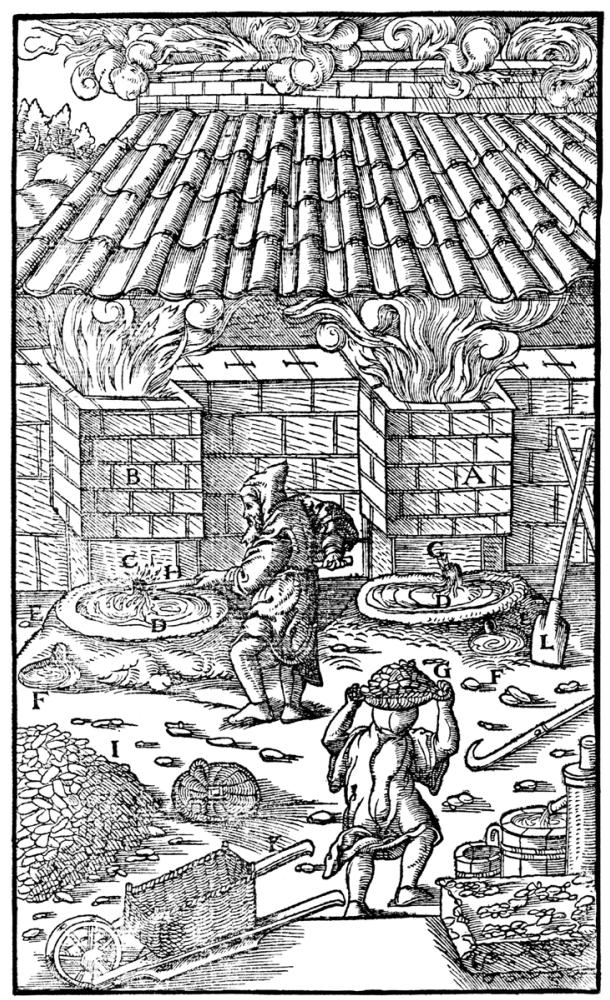

Figure 2.6 German smelting ca. 1550s. Note similarities to the late Bronze Age furnace in Figure 2.4. Except for stack height and the arrangement of the furnaces to better use water power for air blasts, the process appears little changed. (After Agricola 1950, 389.)

One of the significant process changes standardized by $1400 \mathrm{CE}$ was the waterpowered blast. This feature produced higher temperatures, greater output capacity, and the potential for more continuous operation. The timing of the first water-powered blast in the West is unclear. Rome may have used water power for mine pumping and ore processing, and, although not formally documented, they may have used it to power bellows as well. ${ }^{95}$ These features, however, may have been lost in the Dark Ages, only to be "re-discovered" or re-introduced later in the millennium. ${ }^{96}$ (See Figure 2.7)

\footnotetext{
${ }^{95}$ See Andrew Wilson, "Machines, Power, and the Ancient Economy," The Journal of Roman Studies 92 (2002), 1-31.

${ }^{96}$ Tylecote, A History of Metallurgy, 64.
} 


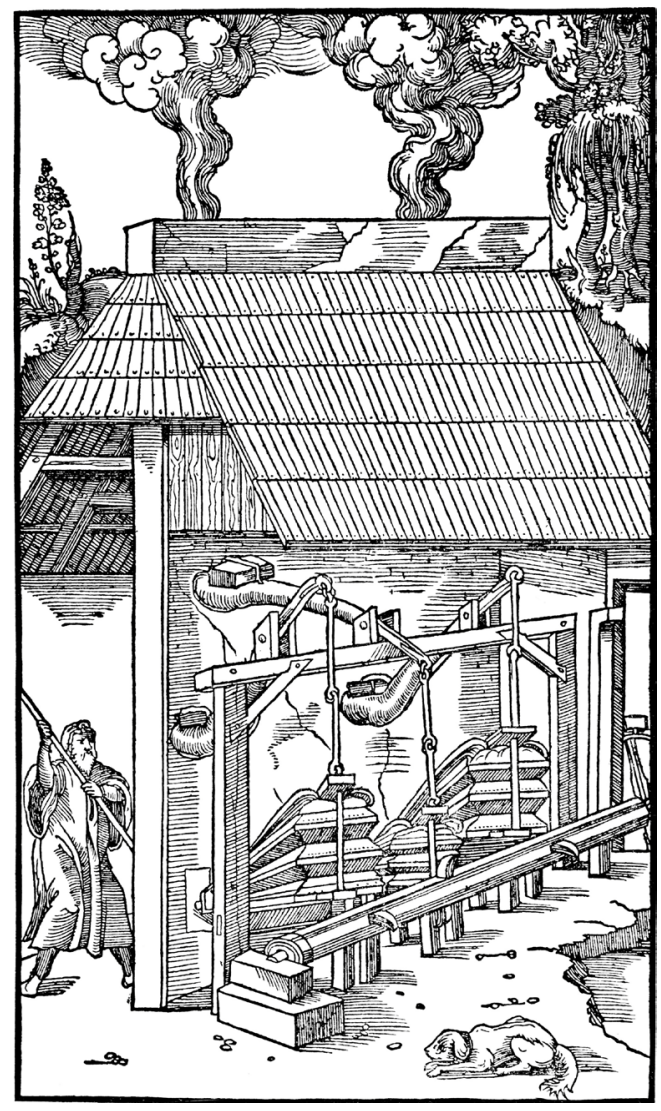

Figure 2.7 Water-driven bellows ca. 1550s used to power smelting furnaces, similar to those in Figure 2.6, located on opposite side of wall. (After Agricola 1950, 359)

\section{Early German Technologies}

The basic German smelting process was similar to the Roman, flowing from roasting, to blast furnace smelting, to refining, but, unlike the ancient methods, it required several more steps to recover precious metals and purify the copper. Following mining and concentrating, iron-rich copper sulfide ore was calcined or roasted in heaps to drive off some sulfur as sulfur dioxide smoke. Sulfur, which is flammable, would continue to burn once ignited for up to 30 days according to Tylecote or 10 weeks according to 
Greenwood. ${ }^{97}$ These now partially desulfurized ores, still containing some un-roasted sulfides, would be reduced in a blast furnace over a 12-hour period to a matte, a partially smelted intermediate metallic compound containing copper sulfides, iron sulfides, and slag.

Next, smelters tapped the molten matte from the furnace, and, after it cooled, they broke up the matte and resmelted it several times in combination with new ore, iron pyrites (sulfide), and quartz flux to enrich the copper content and encourage the formation of iron oxides that combined with the quartz to form slag. During these early operations furnace operators also added lead or lead ores to alloy with silver. This leadsilver combination had a lower melting point than the copper and flowed out of the furnace before any copper melted. The easily melted lead would then be similarly separated from the silver, flowing out of a liquation furnace at a low temperature, leaving behind relatively pure silver.

After numerous smelting operations, the resultant matte "cakes" were mostly CuS (60-90\% copper) and iron sulfide. The matte was then subjected to four additional roastings, each one hotter than the last, to further drive off sulfur and oxidize copper and iron. Halfway through the roasting process, the crushed pieces were remelted or "fused" in another blast furnace, where most of the remaining iron was converted to oxide and slagged. The copper matte was then roasted three more times to drive off the last remaining sulfur, leaving behind a full copper oxide that was then sent to a blast furnace for final smelting resulting in a 90-95\% pure "black" copper. This copper, however, was

\footnotetext{
${ }^{97}$ Ibid., 90; William Henry Greenwood, A Manual of Metallurgy (New York: G. P. Putnam's Sons, 1875), 50. Other sources claim that roasting could take months. The variation is likely due to differing heap sizes.
} 
still not pure enough for most uses and required a final refining that usually included the introduction of green wood poles into the reverberatory furnace's molten copper pool to induce any remaining oxygen to bind with the wood's carbon and form carbon dioxide. ${ }^{98}$ This very long and complicated process is diagramed in Figure 2.8. By the $19^{\text {th }}$ century, Swedish metallurgists had improved the German Method by reducing the several early furnace meltings to a single fusion in a large blast furnace after the initial roasting and a single final fusion after the intermediate roastings. ${ }^{99}$

\section{Spread and Diffusion}

Like the Romans, German miners carried or transferred their mining and smelting technology throughout Europe. Unlike the Romans, however, German miners operated between independent, autonomous political entities with economies based primarily on trade. Many of the medieval German smelters settled in mining regions of other states or were recruited by states hoping to emulate German metal productivity. Other smelters helped establish a basic industry abroad and then returned home. A second critical method of transfer, not used by Rome, occurred through published manuscripts describing mining and smelting techniques. Theophilus' On Divers Arts (1100) and Agricola's De Re Metallica (1556) were both medieval German metallurgical texts, and Vannoccio Biringuccio's Pirotechnia (1540) was an Italian text describing similar contemporary metallurgical procedures.

\footnotetext{
${ }^{98}$ Tylecote, A History of Metallurgy, 93.

${ }^{99}$ Greenwood, A Manual of Metallurgy, 50-54.
} 


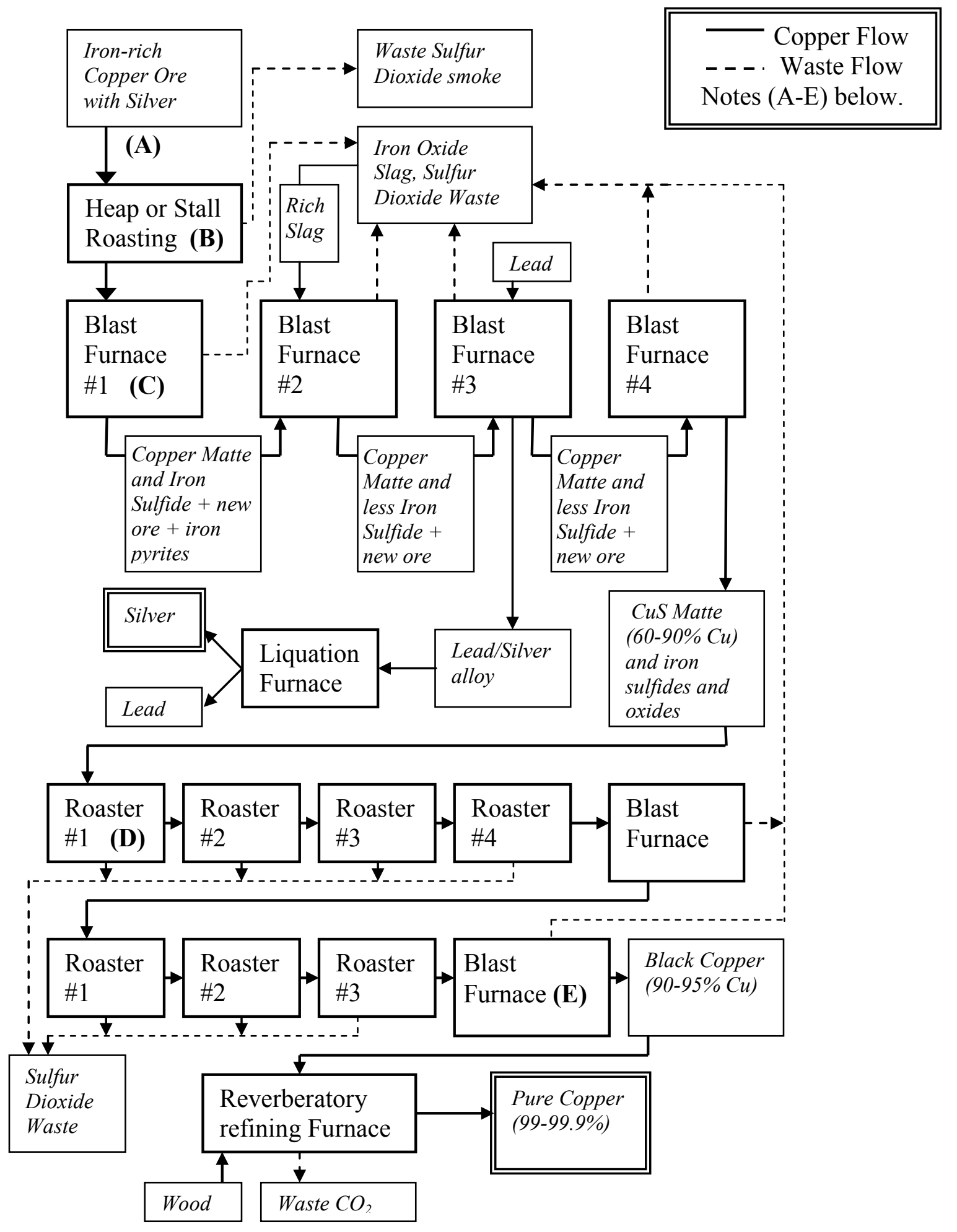

Figure 2.8 German Copper Smelting Process ca. 1550 (Source: Author) 
Figure 2.8 Notes:

A. Fuel (Charcoal) is required at each roasting and smelting phase and quartz flux is added to the blast furnaces to bind with the iron oxides and facilitate slag formation and removal.

B. The initial roast only partially converts the iron pyrite and chalcopyrite (copper-iron sulfide) found in the ore to oxides and releases sulfur dioxide. ${ }^{100}$

$\left[4 \mathrm{FeS}_{4}+11 \mathrm{O}_{2} \rightarrow 2 \mathrm{Fe}_{2} \mathrm{O}_{3}+8 \mathrm{SO}_{2}\right]$

$\left[4 \mathrm{CuFeS}_{2}+7 \mathrm{O}_{2} \rightarrow 2 \mathrm{Fe}_{2} \mathrm{O}_{3}+4 \mathrm{CuS}+4 \mathrm{SO}_{2}\right]$

C. Between blast furnace steps, the matte is cooled, broken up, and put in the next furnace with fresh ores, new iron pyrites, and quartz flux to convert the fresh ore and remaining unroasted chalcopyrite to $\mathrm{CuS}$, convert the iron pyrite to iron sulfides and slaggable iron oxide, and release sulfur dioxide $\left[\mathrm{CuFeS}_{2}+5 \mathrm{O}_{2}+2 \mathrm{FeS}_{4} \rightarrow \mathrm{CuS}+\mathrm{FeS}+2 \mathrm{FeO}+\right.$ $\left.4 \mathrm{SO}_{2}\right]$. Often copper-rich iron oxide slag is returned to one of the blast furnace steps.

D. Between roasting steps, the matte is broken and crushed and fed into the next roaster, operating at a higher temperature, before being fused in the blast furnace. These steps convert all the $\mathrm{CuS}$ from (B) and (C) to copper oxide, the remaining iron sulfide to iron oxide, and the free sulfur to sulfur dioxide $\left[\mathrm{CuS}+\mathrm{FeS}+3 \mathrm{O}_{2} \rightarrow \mathrm{CuO}+\mathrm{FeO}+2 \mathrm{SO}_{2}\right]$. Here, too, copper rich slag may be returned to an earlier blast furnace step.

E. The final blast furnace step completes the smelting process by reducing the copper oxide to black copper and carbon dioxide $\left[\mathrm{CuO}+\mathrm{CO} \rightarrow \mathrm{Cu}+\mathrm{CO}_{2}\right]$. This copper required a refining step to reach $99-99.9 \%$ purity.

Day and Tylecote cite three additional key Middle Age German texts, Nutzlich

Berbüchlin and Probierbüchlien, both anonymous revisions of earlier metallurgical works, and Ercker's Beschreibung Allerfürnemstem Mineralischen (1574), which in 1683

John Pettus translated into English as Fleta Minor, indicating Britain's reliance on continental techniques for post-medieval metallurgy. ${ }^{101}$

\footnotetext{
${ }^{100}$ Chemical equations from Craddock, Early Metal Mining and Production, 149-150. These are general equations for chalcopyrite, a common copper ore, and not necessarily consistent among German method smelters.

${ }^{101}$ Joan Day and R. F. Tylecote, The Industrial Revolution in Metals (London: The Institute of Metals, 1991), 2.
} 
Despite the resources and information contained in published works, access was limited not only to those with the ability to read, but, outside of Germany, to those readers who could understand and interpret German or Latin. Therefore most implementations of continental smelting methods tended to require the movement of skilled workers. In addition to work at Massa Marittima in Tuscany and other historic Roman copper districts throughout the Mediterranean, German workers ventured to other areas that would eventually come to dominate world copper production, be recognized for significant pollution, and in the $20^{\text {th }}$ and $21^{\text {st }}$ centuries become important heritage sites. The first, Falun, Sweden, like the reopened mines in Tuscany, was a German mining and smelting success and used and improved the continental method over several centuries. The second, in the Lake District, United Kingdom, would, for many reasons, ultimately fail to implement German methods. Welsh metallurgists would eventually borrow an element of German technology, the reverberatory furnace, and use it to create a completely new system that would rival, and then dominate world copper production for a century. (See Chapter 3.)

\section{Massa Marittima, Tuscany}

Etruscans and Romans mined and smelted copper, lead, and silver ores in Tuscany starting in the $8^{\text {th }}$ century BCE and ending with the decline of Rome. German miners and metallurgists restarted mining and smelting in the region in $1115 \mathrm{CE}$ when the region became part of the Holy Roman Empire. ${ }^{102}$ Tylecote claimed the process used

\footnotetext{
${ }^{102}$ Tylecote, A History of Metallurgy, 69.
} 
there at the time was a precursor to the method Agricola described two centuries later and suggested it was the first documented procedure to include the intermediate matting step. That is, after initial calcining, furnace workers smelted the ore in a shaft furnace several times to create an impure matte, as described above, which was then refined in a reverberatory furnace. ${ }^{103}$ The region successfully implemented a system of manufacture based on imported German methods though at least the $14^{\text {th }}$ century. ${ }^{104}$

Recent attempts have been made, like the studies of the Rio Tinto estuary discussed above, to link high arsenic levels in the rivers flowing from Massa Marittima and its associated smelting areas to medieval copper smelting, focusing on the disposal of slag and the airborne disbursement of arsenic from historic roasting and initial smelting processes. The findings, however, have ultimately proved inconclusive. ${ }^{105}$

\section{Falun, Sweden}

Falun, one of the longest-lived mining districts in the last two thousand years, and now a World Heritage Site, first began copper production in the $8^{\text {th }}$ century CE and continued into the late $20^{\text {th }}$ century. The oldest surviving document, however, dates only to the 1288 formal incorporation of a mining firm. While Massa Marittima was part of the German-dominated Holy Roman Empire, Sweden was independent, but still attracted and sustained German workers from the $13^{\text {th }}$ century. As German copper output began to wane in the $15^{\text {th }}$ and $16^{\text {th }}$ centuries, the 800 year old Swedish metal industry, including

\footnotetext{
${ }^{103}$ R. F. Tylecote, A History of Metallurgy, Second ed. (The Institute of Materials, 1992), 83.

${ }^{104}$ Manasse, "Chemical and Textural Characterization of Medieval Slags from the Massa Marittima Smelting Sites (Tuscany, Italy)," 187.

${ }^{105}$ Pilario Costagliola et al., "Impact of Ancient Metal Smelting on Arsenic Pollution in the Pecora River Valley, Southern Tuscany, Italy," Applied Geochemistry 23, no. 5 (2008), 1254-1255.
} 
copper from Falun, came, for a short time, to dominate world output. By the mid $17^{\text {th }}$ century, Falun was producing $70 \%$ of the world's copper, and its exports helped finance Sweden's involvement in the Thirty Year's War (1618-1648). Falun ultimately housed 140 smelting furnaces and numerous ore roasting stalls using the system originally installed by the Germans. 106

The high and lengthy production in Falun left considerable toxic residue on the landscape. Ek and her group found high concentrations of mining- and smelting-related copper, lead, and zinc in regional soils especially near mine sites suggesting airborne disbursement. They also found high concentrations of copper, lead, zinc, cadmium, and sulfur in lake sediments, likely from waste dumping or leaching. More dramatic, however, the group estimated that the considerable emissions of sulfur dioxide from roasting and smelting processes over 800 years peaked around 1630 and only significantly declined with the advent of sulfur recovery and sulfuric acid production in $1850 . .^{107}$

Ek's study supports Brovallius' claims in his 1743 treatise, Some findings and comments on the smoke from the roasters in Falun, that the sulfur smell of the roasters could be detected $80 \mathrm{~km}$ from the city and that the process completely devegetated the area around the mine. ${ }^{108}$ Similarly, the Swedish naturalist Carl von Linne wrote in 1734:

\footnotetext{
${ }^{106}$ ICOMOS, "Evaluations of Cultural Properties," ed. Bureau of Cultural Properties World Heritage Convention (UNESCO, 2001), 96-97.

${ }^{107}$ Anna S. Ek et al., "Environmental Effects of One Thousand Years of Copper Production at Falun, Central Sweden," Ambio 30, no. 2 (2001), 97. Falun Smelters released an estimated 40,000 tons of $\mathrm{SO}_{2}$ year during peak production years from 1620-1640. The authors, however, caution that these numbers represent less than $10 \%$ of national $\mathrm{SO}_{2}$ peaks in the 1970 s.

${ }^{108}$ Ibid., 98.
} 
"Never has any poet been able to describe Styx, Regnum Subterraneum and Plutonis, nor any theologus hell as gruesome as we can see it here. For outside a poisonous, acrid and sulfurous smoke rises and poisons the air far and wide so that one cannot without pains go there. The smoke corrodes the earth, so that no plants can grow around"109

Similar descriptions, albeit on a lesser scale, could probably be applied to smaller and shorter-lived copper smelting sites from the Roman period onwards.

Massa Marittima, Falun, and several Saxon mine sites all benefited from the growth and standardization of German mining and smelting techniques partially due to similar mining conditions and rich, accessible lodes. In fact, these were some of the longest-lived and most productive copper sites in the pre-modern era. But not all efforts to transplant the German system were successful. Most notably, the attempt to introduce continental-style smelting techniques to Britain, a region with nearly as long a mining and smelting tradition as Germany, failed.

\section{UK-Lake District}

The output of German mines in Saxony and Bohemia began to slow by the mid$16^{\text {th }}$ century partially due to the combined effects of wars, revolutions, and reformations. But attempts to introduce the fuel-intensive German process into Britain in the $1560 \mathrm{~s}$, during a period of dwindling British timber supplies and high wood demand from navy ship-builders and ironmasters' blast furnaces, proved challenging. This was because conditions in England differed significantly from the continent, not simply because of a

109 Quoted in Ibid., 96. 
lack of fuel, but the rich British copper deposits the Germans tired to exploit proved too deep to reach at the time.

The attempt to import continental techniques into England took several decades. The first attempt to introduce a copper industry into Britain failed to lure German smelters, forcing Henry VIII to continue to rely on continental sources for copper and brass. Further attempts to initiate German mining also failed under both Edward VI and Mary I. ${ }^{110}$ But in 1561, responding to brass demands from woolen textile card-makers, Elizabeth I finally succeeded. By 1564, Germans had established a mining, ore-dressing, and a six-furnace continental smelting operation in Keswick in the Lake District. ${ }^{111}$ Like their European counterparts, smelters in Keswick roasted sulfide ores in the open air and melted them in a water-powered blast furnace, then roasted the output six more times, followed by eight more meltings, with lead added during one of the heats to extract silver. ${ }^{112}$ The chief difference was the use of coal- and peat-fuel early in the process to conserve wood resources and reserve charcoal for only the final smeltings.

The introduction of the German method, however, was beset with difficulties from the start. The imported German miners, for a variety of reasons, did not include a refining phase in the production process. Whether charcoal shortages drove this decision or the miners simply wanted to take black copper back to Germany for final processing to

\footnotetext{
${ }^{110}$ Bruce Donald Maxwell, Elizabethan Copper : The History of the Company of Mines Royal 1568-1605 (London: Pergamon P., 1955), 11.

${ }^{111}$ Day and Tylecote, The Industrial Revolution in Metals, 135.

${ }^{112}$ Ibid., 135.
} 
bolster a declining industry at home, the copper produced in Keswick was not suitable for brass production and ultimately did not curb imports, mostly coming from Sweden. ${ }^{113}$

The accessibility of ore also proved to be a problem. Much of the rich British copper ores were located well below the water table, unlike the German lodes that tended be found in mountainous regions where mines could be drained of water using gravity and a series of tunnels. Without a means to dewater mines, the accessible Lake District copper ore soon diminished. ${ }^{114}$ Other areas with known deposits, like Cornwall, suffered partially because of deep lodes and a lack of local fuels. Ultimately, high-fuel costs led to high Lake District copper prices, and the unrefined, low quality of its black copper led to limited demand and poor sales. ${ }^{115}$

The Keswick copper mines and smelters operated, like the rest of the industry in England, on a "small and erratic scale" until the 1640s. ${ }^{116}$ A second smelting district opened in Neath, southern Wales, to work some of the Cornish ores. Here, too, German miners, traveling from Keswick, established a system based on continental methods. But, here too they ultimately suffered from a lack of accessible ore and constant fuel shortages, although, Tylecote speculates, the operation may have used an experimental reverberatory furnace. ${ }^{117}$ However the contributions made to the British industry are measured, by 1610 all the German works had closed and the miners returned home. ${ }^{118}$

\footnotetext{
${ }^{113}$ Ibid., 136-137.

${ }^{114}$ G. Hammersley, "Technique or Economy; the Rise and Decline of the Early English Copper Industry," Business History 15, no. 1 (1973), 2.

${ }^{115}$ Day and Tylecote, The Industrial Revolution in Metals, 8.

${ }_{117}^{116}$ Hammersley, "Technique or Economy; the Rise and Decline of the Early English Copper Industry," 1.

${ }^{117}$ Tylecote, A History of Metallurgy, 94.

${ }^{118}$ Ibid., 9 .
} 
In any case, by 1640 two key problems - the lack of adequate fuel supplies and water associated with deep ore lodes— had killed the British copper industry. These two obstacles would be addressed with the successful adoption of coal fuel and the implementation of the steam engine pump over the next century. While British historians see these two components as "revolutionizing" the industry, it was also the full implementation of another German technology, the reverberatory furnace, that allowed coal to "revolutionize" British copper production. The combination of coal with reverberatory furnaces led to a new smelting process that ultimately became know as the "Welsh" system. ${ }^{119}$

\footnotetext{
${ }^{119}$ Day and Tylecote, The Industrial Revolution in Metals, 139.
} 


\section{CHAPTER 3. THE WELSH SYSTEM}

Copper was won from its ore by smelting operations which seem rather indecisive when compared to the way in which great pigs of iron were regularly born out of the belly of the blast furnace. (Editor's note accompanying Diderot's 1766 plates on copper smelting)

- Charles Gillispie, 1959

In A Diderot Pictorial Encyclopedia of Trades and Industries (1959), historian of science Charles Gillispie suggested that $18^{\text {th }}$-century copper production was somehow less decisive, assured, or even dramatic than iron production. ${ }^{120}$ Given the complexity of copper smelting and the countless process variations based on ore types and fuel and flux choices, this appeared true especially when compared with much larger, productive, yet simpler iron blast furnaces. Iron production required only three inputs into the top of a furnace - iron ore, carboniferous fuel, and limestone flux — and one input into the lower part of the furnace - forced air - to produce significant quantities of metal in just one relatively short heat lasting only a matter of hours. Copper production, after evolving for 5000 years, still required no less than six, but often more than twelve, steps including multiple and varied inputs, multiple roastings, and multiple heats that could last, in total, up to a month or more.

Gillispie, enlisting Denis Diderot to further his point, quoted the $18^{\text {th }}$-century encyclopedist, although more a philosopher than a technician, who decried the benighted traditionalism of men of ores (implying copper smelters) for remaining "stubbornly

\footnotetext{
${ }^{120}$ Charles C. Gillispie, ed., Diderot Pictorial Encyclopedia of Trades and Industry (New York: Dover Publications, 1959), Plate 139. Gillispie, while not quoting directly, may be paraphrasing Diderot's other writings by using the word "indecisive" to describe $18^{\text {th }}$ century copper smelting, which by 1959 should not have been considered indecisive at all, especially by a historian of science, but rather very complex, specific, and determined.
} 
attached to their old methods... because there are none whose methods are less

enlightened."121 While clearly a metaphor for social evolution during the Enlightenment, Diderot either did not grasp or chose not to recognize the significant changes to copper smelting developing in his own lifetime. It is true that the first application of coke to blast furnaces (1709) merely half a century before the publication of Diderot's Encyclopédia significantly changed iron making, but the application of the reverberatory furnace in Wales and the rapidly evolving Welsh smelting system in Diderot's own time had a similar effect on copper production. While the reverberatory furnace was not a new development in the late $17^{\text {th }}$ century, the Welsh system's reliance on it was, and the new methods ultimately led Wales to world production dominance in the $18^{\text {th }}$ and $19^{\text {th }}$ centuries, especially as productive regions using the German system began declining.

\section{The Reverberatory Furnace}

The reverberatory furnace was not a new invention when incorporated into the Welsh system. In fact, different industrial processes had used some variation of this furnace for thousands of years. Its key features included a separate combustion chamber that isolated fuel and its potential contaminants from the materials being melted in the hearth and a heat distribution system that reflected heat off the furnace ceiling down onto the hearth without mixing the combustion gases with the melt. In most cases, the furnace relied on a natural draft created by a tall stack (flue) located opposite the combustion chamber to draw air into the fire, distribute heat along the furnace ceiling, and vent the

\footnotetext{
${ }^{121}$ Ibid, Plate 140. Translated, quoted, yet uncited by Gillispie accompanying a plate on copper smelting.
} 


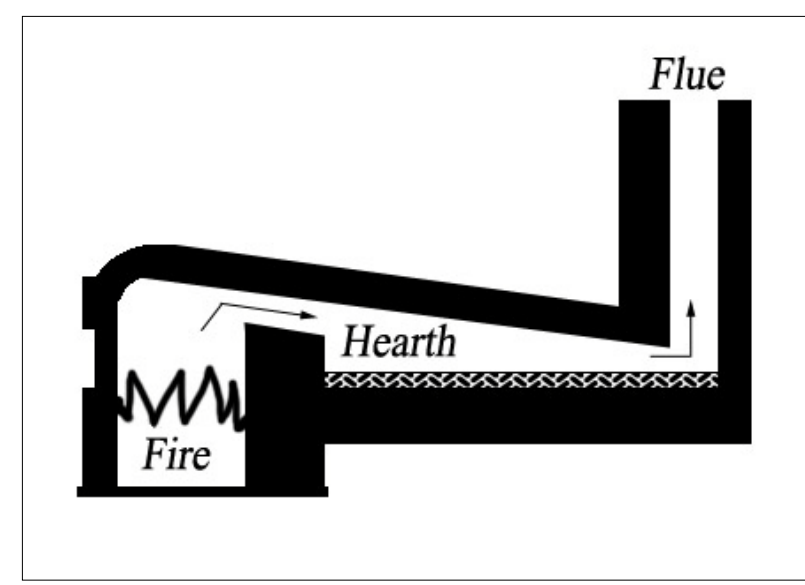

Figure 3.1 Typical Reverberatory

Furnace Arrangement (Source: Author) waste gasses. (See Figure 3.1) These features kept the hearth materials free from impurities found in the fuel and, as such, permitted use of a much greater diversity of fuels and, in most cases, resulted in a much purer metal. In addition, the flue-draft arrangement allowed smelters to locate furnace sites virtually anywhere because they did not have to be tied to streams for water power to drive blast-furnace bellows.

Coghlan suggested that early pottery kilns, the likely source of the first copper smelters, evolved into reverberatory-style furnaces with separate combustion and hearthchambers and a flue chimney providing the draft. ${ }^{122}$ By the Roman period, pottery kilns had evolved into fairly sophisticated furnaces with reflective square-vaulted or circulardomed hearths, heated from below by a separate fire box directing heat (and smoke) through a grated floor. A small opening in the top of the dome served as a smoke release and flue. $^{123}$ (See Figure 3.2)

${ }^{122}$ H. H. Coghlan, "Some Experiments on the Origin of Early Copper," Man 39, no. July (1939), 107.

${ }^{123}$ Henry Beauchamp Walters and Samuel Birch, History Ancient Pottery, Greek, Etruscan, and Roman, 2 vols. (London: J. Murray, 1905), 444. 


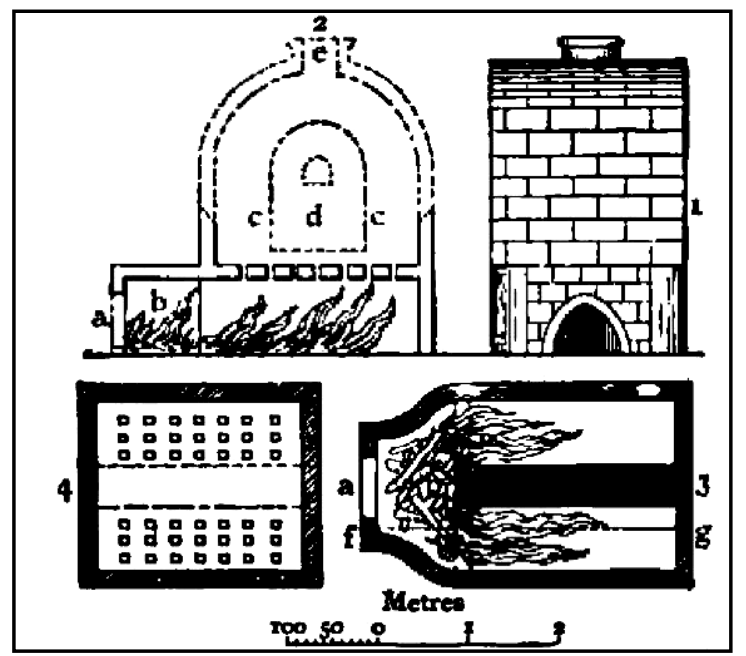

Figure 3.2 Roman Era Pottery Kiln (After Walters 1905, 444)
Theophilus was the first known

western writer to describe a furnace

primarily using reverberated or reflected

heat. These furnaces, found in glass

production, dated to the $12^{\text {th }}$ century and

operated similar to Roman pottery kilns with

separate fire boxes, but were longer and

more rectilinear with only a slightly concave

ceiling. The heat of combustion, instead of

being directed through the hearth floor from below, traveled along the furnace ceiling reflecting downward similar to later, true-reverberatory furnaces. ${ }^{124}$ (See Figure 3.3)

While Theophilus did not specify the draft arrangement of the glass furnace, he described a brass-making crucible furnace that, like a reverberatory furnace, drew air into the fire through an induced draft from the furnace flue. ${ }^{125}$

The earliest intentional application of reverberatory furnaces to metallurgy remains a mystery. Since the technology existed and was widely known prior to the Roman Empire, it is likely that early metallurgists knew of the glass-maker's and potter's furnaces and their ability to reach high melting temperatures. While metal works would have found two main features of the reverberatory furnace, a separate fuel box and a natural flue-draft advantageous, the chief drawback to the potters furnace, its high fuel

\footnotetext{
${ }^{124}$ Theophilus, On Divers Arts; the Treatise of Theophilus, trans. John G. Hawthorne and Cyril Stanley Smith, Dover Publications, Inc. 1979 reprint ed. (Chicago: University of Chicago Press, 1963), 50. ${ }^{125}$ Ibid., 141.
} 


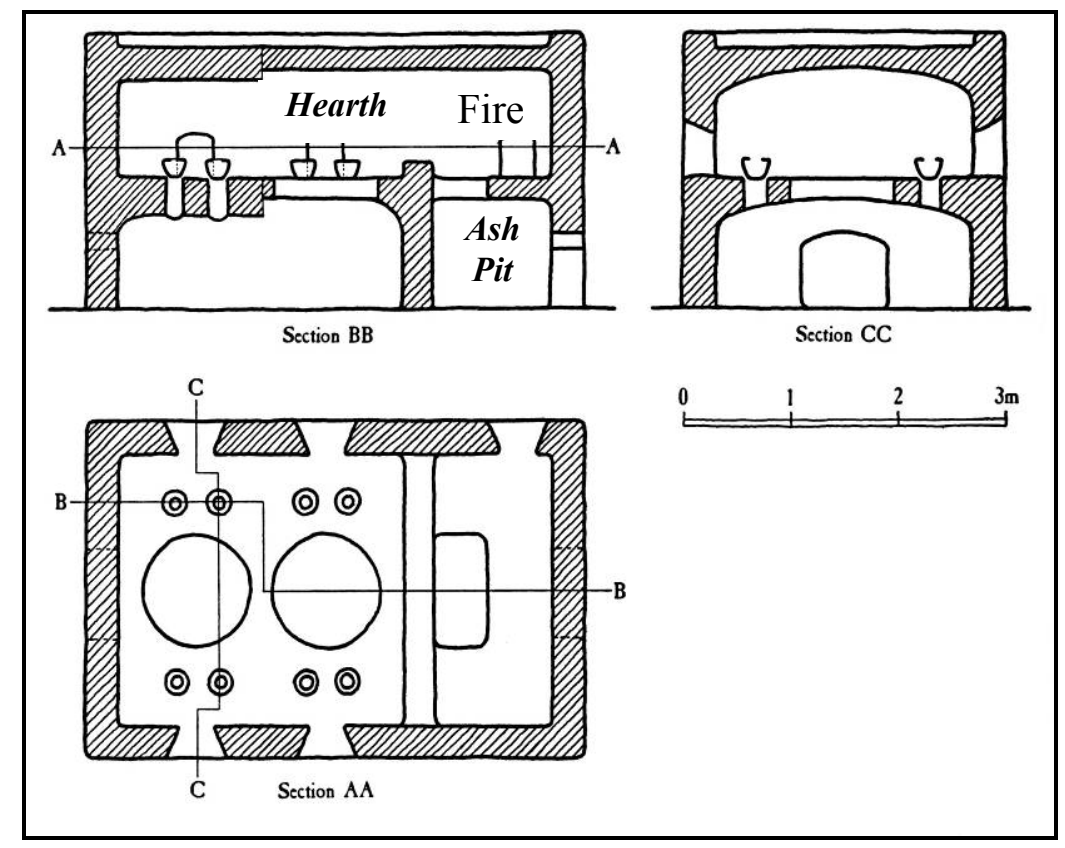

Figure 3.3 $12^{\text {th }}$ Century Glass Furnace.

(After Hawthorne and Smith in Theophilus 1963, 50)

consumption, may have rendered it too expensive to adapt, especially while the blast furnace and abundant wood resources proved adequate. A further problem could have been the complexity of the reduction and oxidation reactions which may have been too difficult to control (if understood at all) in early reverberatory furnaces. They would still plague the furnace in the late $17^{\text {th }}$-century British copper industry.

Given these limitations, metallurgists for millennia tended to focus on improving known blast-furnace technology. But the advantages of the reverberatory furnace eventually overcame the difficulties, and the first metallurgical application of the furnace likely occurred when users required a less contaminated, purer metal or alloy than a blast furnace could produce. British metallurgical historian R.F. Tylecote suggests that metal 
workers at Massa Marittima (Italy) used a reverberatory furnace for copper refining possibly as the early as the $12^{\text {th }}$ century, and that the melting furnace depicted in the $14^{\text {th }}$ century York Minster Bell Founder's Window (UK) is reverberatory. ${ }^{126}$ Similarly, Jenkins cites two German reverberatory furnaces used primarily for bronze melting and smelting in gun-foundries as early as the 1480s, and a Leonardo da Vinci sketch of a furnace with a separate fire-box dates from that same period. ${ }^{127}$

In any case, by 1540 the reverberatory furnace had become a known and advanced feature of some metal works as evident by the discussion in Biringuccio's Pirotechnia. Biringuccio notes the furnace's use in roasting and smelting ores and in the remelting and production of bronze. He also describes Leonardo da Vinci's plan to use reverberatory furnaces to cast a bronze colossus horse for the Duke of Milan. ${ }^{128}$ Agricola, however, does not mention the reverberatory furnace directly in De re Metallica (1556), but hints at it by including a drawing of a domed roasting furnace with a separated fire box inside the hearth. ${ }^{129}$ In another section, Agricola describes a Saxon furnace, "not unlike a baking oven," fueled through a hole in the back of the hearth used to smelt lead. ${ }^{130}$ Baking ovens of the period looked very similar to Roman pottery kilns with domed roofs and offset fires, the technology was well suited and well timed for new development with new fuels.

\footnotetext{
${ }^{126}$ R. F. Tylecote, A History of Metallurgy, Second ed. (The Institute of Materials, 1992), 83-84.

${ }^{127}$ R. Jenkins, "The Reverberatory Furnace with Coal Fuel," Transactions of the Newcomen Society 14 (1934), 68.

${ }^{128}$ Vannoccio Biringuccio, The Pirotechnia of Vannoccio Biringuccio (Cambridge, Mass.: M.I.T. Press, 1966),151, 281, 285. Leonardo da Vinci never completed the sculpture because a war with France led to the occupation of the castle.

${ }^{129}$ Jenkins, "The Reverberatory Furnace with Coal Fuel," 68.

${ }^{130}$ Georgius Agricola, De Re Metallica, trans. Herbert Hoover (New York,: Dover Publications, 1950), 391.
} 


\section{The Welsh System}

The Welsh system evolved in the United Kingdom over the $18^{\text {th }}$ century based on three developments: (1) the successful adoption of the coal-fired reverberatory furnace in place of German-system blast furnaces, (2) a significant legal reversal, and (3) growing demand for copper in specific markets. Historians have well documented the British wood crisis of the $16^{\text {th }}$ and $17^{\text {th }}$ centuries and the significant boost coal-fuel provided to industrial output and technological development in Britain. The adoption of the reverberatory furnace was part of this transition. A key component of the $16^{\text {th }}$ - and $17^{\text {th }}-$ century failure of German process blast-furnaces in the British copper industry was inadequate fuel for the furnaces and insufficient capability to dewater deep mines. Smelting English and Cornish copper with coal-fired reverberatory furnaces and the eventual pumping of mine waters with Welsh-coal-fired steam engines solved both of these bottlenecks in United Kingdom copper production. (See Figure 3.4)

Nearly as important, the British government reversed the 1568 monopolies it had granted to the Society of the Mines Royal and the Society of the Mineral and Battery Works to operate mining and smelting works, and manufacture brass. ${ }^{131}$ Prior to instilling a patent system in the $17^{\text {th }}$ century, the crown used monopolies to protect investments and encourage new development, ultimately intending to end the country's reliance, in this particular case, on imported copper. As discussed in Chapter 2,

\footnotetext{
${ }^{131}$ G. Hammersley, "Technique or Economy; the Rise and Decline of the Early English Copper Industry," Business History 15, no. 1 (1973), 3.
} 


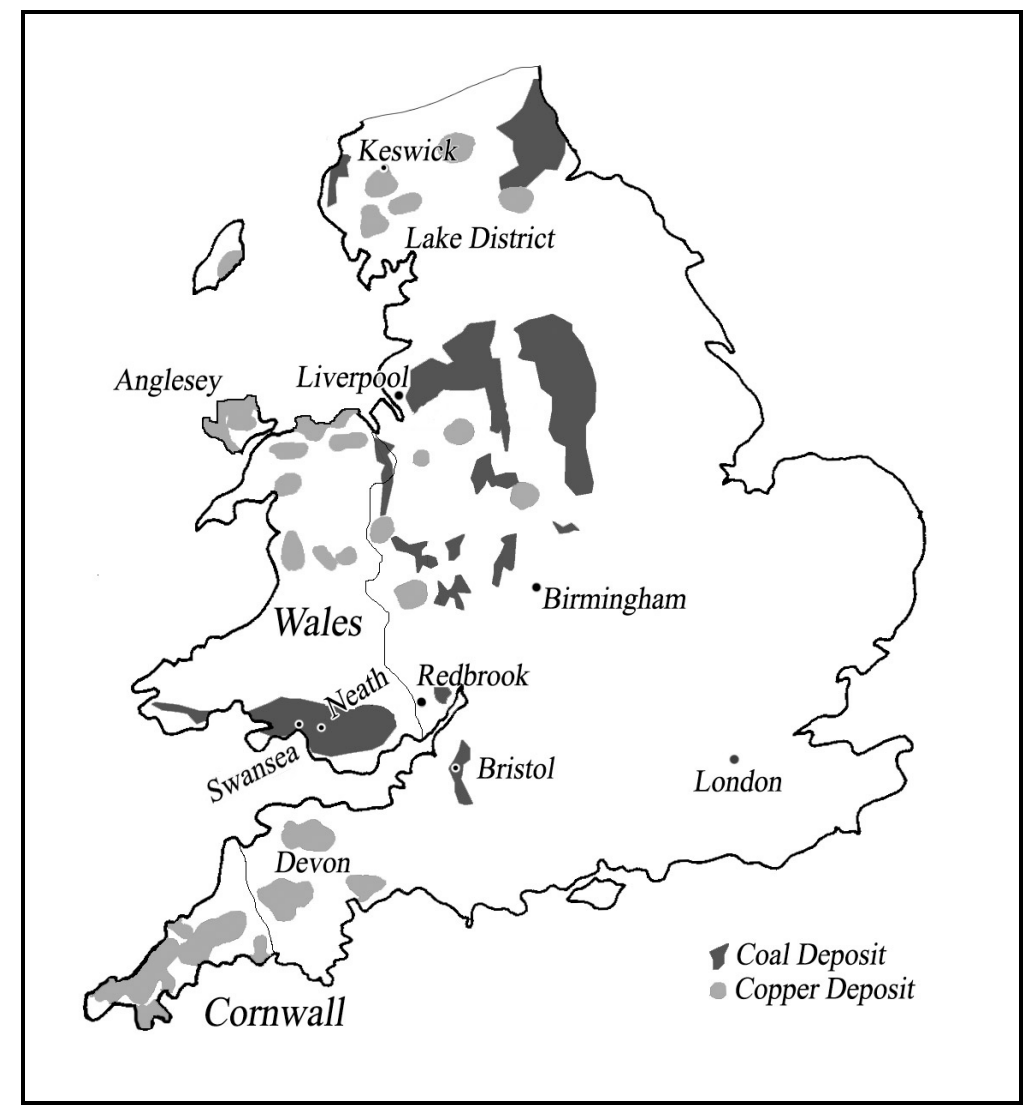

\section{Figure 3.4 Location of British and Welsh Coal and Copper Deposits}

(After Day and Tylecote 1991, 132)

however, attempts to create new copper production systems failed, and the monopolies actually stifled new development instead of encouraging it. In 1689, Parliament passed the Mines Royal Act, substantially limiting the rights and powers of the former monopolies. This act, combined with improving reverberatory smelting techniques, finally made copper production "commercially possible" for many small producers and led to substantially increased output starting in the 1690 s. $^{132}$

\footnotetext{
132 Joan Day and R. F. Tylecote, The Industrial Revolution in Metals (London: The Institute of Metals, 1991), 140
} 
In the early $17^{\text {th }}$ century, Parliament shifted from assigning monopolies to granting patents to encourage industrial development. Like monopolies, patents protected early innovators, but unlike monopolies, the patent system permitted others to develop alternative industrial processes for the same ultimate output. Even though many of the alternative methods were efforts to sidestep royalty payments to patent holders, new technologies and innovations followed.

The emergence of three new key markets for copper in the $18^{\text {th }}$ century further contributed to the evolution of the Welsh system. First, several copper smelters began operations in the late $17^{\text {th }}$ and early $18^{\text {th }}$ centuries focused on producing a purer copper to be used in the growing brass industry. While smelters were scattered throughout western England, Wales, and Cornwall, the production of brass tended to be centered on Bristol and the Bristol Brass Company, which dominated the regional industry for most of the $18^{\text {th }}$ century. Royal Mint contracts formed a second key new market for copper but the copper-alloy coins produced for the Mint did not require as high a grade of copper as brass works. The dominant contractor was the Governor and Company Copper Miners in England or, more commonly, the English Copper Company. This market, however, was not as regionally fixed as the brass market and tended to have facilities closer to London. The third market to develop in the late $18^{\text {th }}$ century was the ship sheathing and cladding industry centered in northern Wales. It used copper sheet to protect wooden-hulled ships from rot and marine encrustations. Here, too, a very pure copper was not required, but substantial rolling and nail-production processes were. 
Despite new market demands and a continuing fuel shortage, the reverberatory furnace was not an immediate success. Yes, it could be fired with multiple fuels, giving it a distinct advantage over blast furnaces, but for the first twenty years of its use in copper smelting, it proved difficult to operate and did not eliminate the impurities in the ore necessary for good brass. ${ }^{133}$

Day and Tylecote date the first successful reverberatory copper smelter to the late 1680s in Bristol. There, lead smelter operator Lord Grandison invoked his patent rights and forced Clement Clerke to stop smelting lead with coal in a reverberatory furnace. Undeterred, Clerke simply developed a very similar copper smelting system and was issued a patent in 1687 for "a new invention, being severall sorts of furnaces, vesels, wayes and meanes that never before were knowne." ${ }^{134}$ Although Clerke's Bristol copper works failed to survive beyond 1697, it left behind two important legacies. John Coster, the technician largely credited with successfully implementing Clerke's copper reverberatory furnaces, left the company shortly after 1687 and, by 1691, had opened the Upper Redbrook works in southeastern Wales. The second legacy was the Lower Redbrook works, opened by the English Copper Company in 1691 in nearly the same location as Coster's, with patent rights purchased from the Clerkes. ${ }^{135}$ This feature of locating competing works in direct proximity to each other became a hallmark of the industry since companies could rely on a density of skilled labor and the knowledge base of a stable technical community.

\footnotetext{
${ }^{133}$ G. Hammersley, "The Effect of Technical Change in the British Copper Industry between the Sixteenth and Eighteenth Centuries," Journal of European Economic History 20 (1991), 161.

${ }^{134}$ Quoted in Day and Tylecote, The Industrial Revolution in Metals, 138.

${ }^{135}$ Ibid., 139.
} 
Coster's Upper Redbrook system relied mostly on reverberatory furnaces with the exception of the final refining, which used a shaft furnace because his copper was primarily destined for the Esher Brassworks outside London, which required a highly pure metal still not attainable in a reverberatory furnace alone at the time. While Tylecote considers the Upper Redbrook arrangement a transitional step between the continental system and the Welsh system, he also suggests that the use of the blast furnace could have been a means to either avoid paying patent royalties to the Clerkes or, more likely, an indication that he was prevented from using the system patented by the Clerkes. ${ }^{136}$ The English Copper Company, on the other hand, purchased inventions from and ultimately hired Gabriel Wayne, a former colleague of Coster, to manage its Lower Redbrook works. Beginning in the 1690s, Wayne produced coinage copper for the Royal Mint using multiple reverberatory roastings and smeltings similar to the Clerke patent. Although the smelter was a key producer, ore-supply problems prompted Wayne to leave a few years later for Bristol, where he opened a smelter in Conham just north of the city in $1696 .{ }^{137}$

In 1706, a fourth significant smelter operation opened at Crew's Hole outside Bristol to access cheap coal and feed growing copper demand. If Tylecote felt the Upper Redbrook works was a transitional site, then he would have clearly believed that the Crew's Hole works demonstrated, by 1725, the first concrete elements of Welsh system. Not only were its furnaces bigger than the three earlier works, but the smelting process had evolved more completely. A Crew's Hole smelter run began by roasting a selection

\footnotetext{
${ }^{136}$ Ibid., 143.

${ }^{137}$ Ibid., 141.
} 
of high-sulfur ores in a large reverberatory furnace before mixing the ores with higher grade unroasted ores, lime, silica, and slag from previous runs in a reverberatory melting furnace. The resultant matte was broken up and furnace-roasted for up to 24 hours before the temperature was increased to melt the roasted matte. The copper was then slagged, allowed to cool, and broken up again while some of the rich slag was saved for the next furnace heat. This process was repeated up to 20 times until the necessary grade of copper was reached. This copper was then refined in a small reverberatory furnace fueled in the first part of the heat with coal and then charcoal, before the copper was poled to reach a high purity. ${ }^{138}$

By 1754 the basic elements of the Welsh system had been developed, but as an industry, it was still in its formative stage. Through the end of the century, new British copper smelting districts opened, but these failed to fully mature because the cost of fuel was too high (Cornwall), the cost of ore was too high or ran out (northern Wales), or both (London). While Cornwall and London never posed much threat to the growing southern Welsh smelting industry, the Anglesey region in northern Wales did. Controlled by Thomas Williams, the new Parys Mine Company built or took over several smelting operations in and around Liverpool in the 1780s, to add to its growing mining interests in Anglesey. The company also acquired the Upper Banks works in Swansea in 1782.

With the growth of the ship-cladding market for tropical-going naval ships and, later, merchant vessels, the Parys Mine group developed new smelting procedures for copper destined for rolling mills, then patented processes for rolling copper sheet and

\footnotetext{
${ }^{138}$ Ibid, 145.
} 
manufacturing copper nails and bolts. ${ }^{139}$ Just as mine production was beginning to decline in Anglesey, Williams died, and in 1802 the company began, like many others, to focus its attention on its Swansea works. Within 12 years it had closed most of its northern Welsh mines and smelters, maintaining only works in the south. ${ }^{140}$

One by one, the major British copper smelting works located outside of southern Wales either closed altogether, or by 1800 , had moved to or purchased additional works in southern Wales. The English Copper Company bought a Swansea works in 1739, the Pays Mining Company in 1782, and Bristol Brass in 1793. Appreciating the advantages of southern Wales, more than 15 separate copper smelting works operated along the Tawe River in or near Swansea between 1717 and 1928, and over 13 other major industrial works opened including important steel and tin-plate works. ${ }^{141}$ By 1845 , Swansea smelters were producing $55 \%$ of the world's copper and, at its peak in 1860 , the industry operated 600 furnaces in the region. ${ }^{142}$ The population of the area also boomed growing from 900 in the 1540 s to 10,117 in 1801 to 152,619 in $1911^{143}$

\section{Swansea}

The River Tawe and its port city Swansea offered significant advantages to industries relying on shipping-based imports and exports. The river itself provided deep

\footnotetext{
${ }^{139}$ J. R. Harris, "Copper and Shipping in the Eighteenth Century," The Economic History Review 19, no. 3 (1966), 558.

${ }_{140}$ Day and Tylecote, The Industrial Revolution in Metals, 156-157.

${ }^{141}$ City and County of Swansea, A Short History of the Hafod Works (Welsh Assembly Government, 2007), 6-7 (insert).

${ }^{142}$ Gerald Gabb, Lower Swansea Valley Factsheet 7: The Rise and Fall of the Copper Industry (Swansea: Swansea Museum's Service, unknown date), 4. In mid century, eight other Welsh smelters operated in Llanely and Neath, and eight northern English smelters operated in Amlwch (Anglesey), Liverpool, St. Helens, and Cheadle. (Percy, 1861, 307)

${ }^{143}$ Swansea, A Short History of the Hafod Works, 2 (insert).
} 
water access a significant distance up-stream, allowing works to be built farther up from the port city. With the growth of industry, the region offered smelter owners and mangers access to industrial labor and technical expertise. Most important for copper works, Swansea's regional coal fields were closer to Cornish and Devon copper deposits than any other coal region. However, the key to the success of southern Wales lay not simply in geographical advantages, but in the development of a system of smelting based on the nuances of local fuels, the importation of new ore from sources from around the globe, and the creation of new markets for copper.

The growth of capitalism and steam-power were particularly important to Swansea. Steam-power made the manufacture of smaller market-goods much cheaper. Inexpensive silver-plated, stamped-copperware, for example, became much more accessible as a silverware substitute, and stamped copperware pans and other utensils became affordable to the working classes. The spread of the steam-engine and steamlocomotives and steamships increased the demand for copper boiler plates, copper piping, and brass cylinders. Cheap copper and the even cheaper Muntz metal (36-45\% Zinc) made copper sheathing for building roofs and ship's hulls available on a much greater scale, and the spread of the international slave trade required substantial inputs of copper trinkets and trade goods - all driving the need for increased copper smelting and encouraging attempts to improve the industry. ${ }^{144}$

The advantages to copper smelters in the Swansea district were manifold, especially as world demand for copper grew and continental copper production fell. The

\footnotetext{
${ }^{144}$ Stephen Hughes, Copperopolis : Landscapes of the Early Industrial Period in Swansea (Aberystwyth, Ceredigion: Royal Commission on the Ancient and Historical Monuments of Wales, 2000), $36,38$.
} 
first successful reverberatory smelter to operate in the area ran from 1694 to 1717 in nearby Neath, home to a short-lived $16^{\text {th }}$ century German smelter works. After the latter works closed, two of the partners opened a smelter in Landore in 1726, about one mile up the Tawe from Swansea-proper. The new owners, including John Morris, successfully operated the site over twenty years, firmly establishing both the smelting district and the wealth of the Morris Family, who would become one of the dominant Swansea family firms. ${ }^{145}$ In 1734, the Costers opened a Neath smelter to process matte produced at their Hayle (Cornwall) works. This site was purchased by the English Copper Company in 1739, at the same time the Coster family began constructing the White Rock works in Swansea.

District growth and continental decline through the $18^{\text {th }}$ century continued, and by 1810, the United Kingdom produced four times the combined copper output of the former major producers: Germany, Sweden, and Norway. ${ }^{146}$ By the mid- $19^{\text {th }}$ century, Swansea and the River Tawe Valley were a congested mass of smelter firms and workers housing with a substantial pollution problem. (See Figure 3.5 and Table 3.1)

Many of the Welsh smelter works, including those in the Tawe River valley were ultimately managed by a succession of family firms and partnerships, often for many generations. The Costers and Clerkes, mentioned above, were two of the earliest. John Williams of the Parys Mine Company, his son, or a descendant company dominated by the Pasco Grenfell family owned the Upper and Middle Bank works, Landore II, the Rose

\footnotetext{
145 Day and Tylecote, The Industrial Revolution in Metals, 150.

${ }^{146}$ Hughes, Copperopolis : Landscapes of the Early Industrial Period in Swansea, 2. Hughes reports that for the decade from 1801-1810, the UK produced 65,000 tons of copper to Sweden's 7,000, Norway's 4,8000, and Germany's 3,7000.
} 
Figure 3.5 Swansea and the River Tawe Valley 1840.

(After Hughes 2000, 15)

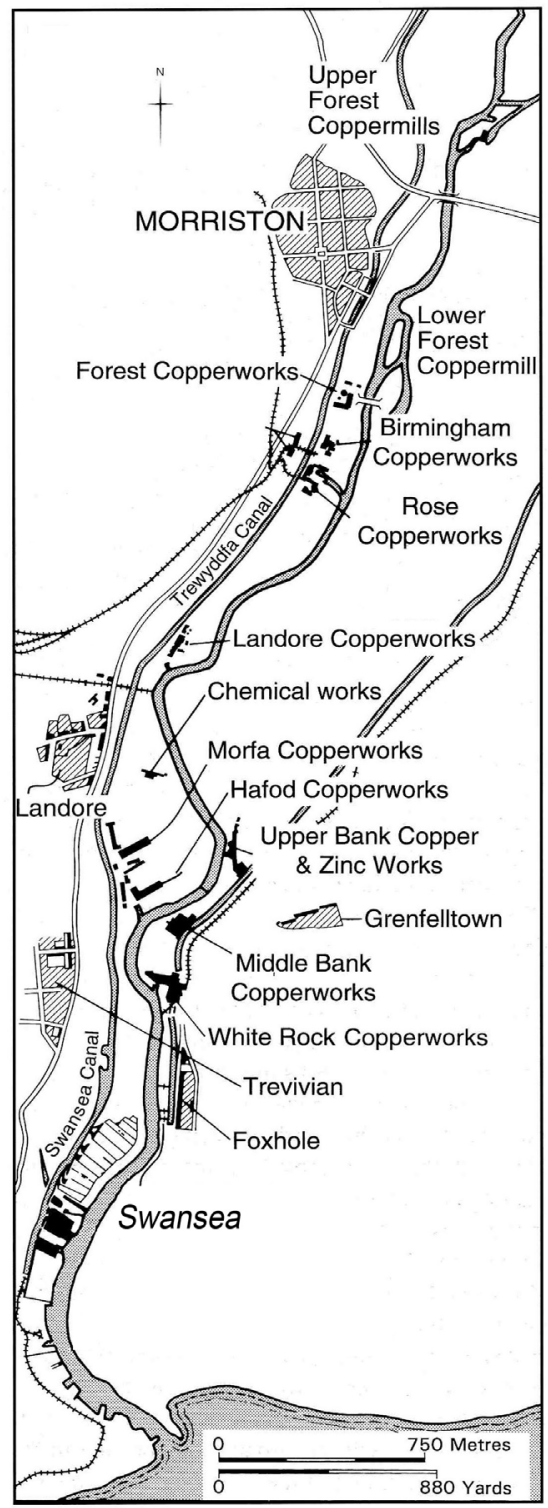

Table 3.1 Growth of Copper Smelter Industry in Swansea (1717-1928)

\begin{tabular}{|l|c|c|}
\hline $\begin{array}{l}\text { Smelter } \\
\text { Company }\end{array}$ & $\begin{array}{c}\text { Start } \\
\text { Date }\end{array}$ & $\begin{array}{c}\text { End } \\
\text { Date }\end{array}$ \\
\hline Landore I & 1717 & 1748 \\
\hline Cambrian Works & 1720 & 1745 \\
\hline White Rock & 1737 & 1928 \\
\hline Forest & 1746 & $1850 \mathrm{~s}$ \\
\hline Middle Bank & 1755 & 1924 \\
\hline Upper Bank & 1757 & 1928 \\
\hline Rose & 1780 & 1878 \\
\hline Birmingham & 1793 & 1833 \\
\hline Landore II & 1793 & 1876 \\
\hline Hafod & 1810 & 1924 \\
\hline $\begin{array}{l}\text { Nant-rhyd-y- } \\
\text { Vilias }\end{array}$ & 1814 & 1817 \\
\hline Morfa & 1835 & 1924 \\
\hline Landore III & 1853 & 1855 \\
\hline Little Landore & 1863 & 1896 \\
\hline Llansamlet & 1866 & 1905 \\
\hline
\end{tabular}

From: Swansea, A Short History of the Hafod Works, page 6-7 inserts. 
works, and the important Mofra works. ${ }^{147}$ Similarly, the Morris family or its descendant companies owned, at one time, Landore I and II, the Forest works, and important copper battery works. ${ }^{148}$

The most visible and probably dominant family in Swansea, however, was made up of the decadents of smelterman John Vivian. The Hafod Works, founded by Vivian and his sons in 1810, was owned and controlled by the family-firm for its entire existence, and the family also purchased the White Rock Works across the river and opened additional works in Neath. The Vivian's works became, by the mid- $19^{\text {th }}$ century, the largest smelting operation in the world, challenged in size only by the adjacent Morfa works. As the largest firm, Hafod became most studied and documented works in the district and also the primary focus of pollution lawsuits.

\section{Welsh System Smelting}

By the mid $19^{\text {th }}$ century, the Hafod works epitomized the Welsh system. Its smelting furnaces were all reverberatory, but it also used blast furnaces for some operations, including refining of copper-rich reverberatory furnace slag — an idea borrowed from the Michigan copper district. Hafod also minimized its use of outside fluxing agents by employing a variety of ore mixes imported from throughout the world.

\footnotetext{
${ }^{147}$ Swansea, A Short History of the Hafod Works, 8 (insert).

${ }^{148}$ Hughes, Copperopolis : Landscapes of the Early Industrial Period in Swansea, 17.
} 
Many metallurgical writers documented the Welsh system as practiced at the Hafod works in the 1840 s and 1850 s. The system used two primary types of reverberatory furnaces. (See Figure 3.6) The larger calcining furnace was used at temperatures below the ore's melting point for initial roasting to release sulfur, and the smaller melting furnace operated at much higher temperatures. The Vivian's ultimately used four different furnace types based on the two main designs in their process. ${ }^{149}$



Figure 3.6 Typical Welsh calcining and melting reverberatory furnaces. (After Greenwood 1875, 26, 31, 31)

Another important key in the Welsh system was the complex mix of ores charged into the furnace to minimize extra materials needed to create slag and maximize the

${ }^{149}$ John Percy, Metallurgy. The Art of Extracting Metals from Their Ores (London,: J. Murray, 1861), 314322. 
removal of waste material from the copper. After ores arrived in Swansea, smelters assayed the rock to determine its copper, iron, sulfur, and silica or quartz content. In 1852, James Napier listed 62 different ores from Cornwall and Devon ranging in content from $3.6 \%$ to $19.1 \%$ copper and 37 different ores from Ireland, Wales, Cuba, Chile, New Zealand, and Australia ranging from $8.2 \%$ to $58 \%$ copper. ${ }^{150}$ Ten years later, Snowden Piggot described a more formalized classification system used at Hafod to rate ores based on copper content. ${ }^{151}$ (See Table 3.2)

Table 3.2 Ore Classification System used in Swansea in the 1850s.

\begin{tabular}{|l|l|l|}
\hline Ore Class & $\begin{array}{l}\text { Copper } \\
\text { Content }\end{array}$ & Description \\
\hline I & $\mathbf{3 - 1 6} \%$ & Copper pyrites, high silica gangue \\
\hline II & $\mathbf{1 5 - 2 5 \%}$ & Richer copper pyrites \\
\hline III & $\mathbf{1 2 - 2 0 \%}$ & Copper pyrites with little additional iron pyrite \\
\hline IV & $\mathbf{2 0 - 3 0 \%}$ & Copper oxides and carbonates \\
\hline V & $\sim \mathbf{8 0} \%$ & Rich Chilean and Australian oxides, silica gangue \\
\hline
\end{tabular}

The basic Welsh process consisted of six primary steps. (See Figure 3.7 at the end of this discussion.) In the first step (1), smelters mixed the ores based on assayed composition. In the 1850s these included yellow ore, iron pyrites, and hematite from

\footnotetext{
${ }^{150}$ James Napier, "On Copper Smelting," The Philosophical Magazine and Journal of Science 4 (1852), 4849.

${ }^{151}$ A. Snowden Piggot, The Chemistry and Metallurgy of Copper" (Philadelphia: Lindsay \& Blakiston, 1858), 289-290.

${ }^{152}$ Napier, "On Copper Smelting," 454. Based on Procédés Métallurgiques by M. Le Play, Napier described Class III ores as having a low sulfur content requiring no calcination and provided the copper content listed. He also described Class V ores as similar to I with few metallic impurities, listed Class VI ores as rich oxides, and Class VII as cobbing, or yard scrap copper.
} 
Cornwall; copper and iron pyrites from Devonshire; both high- and low-grade Cuban pyrites; Irish copper oxides (by-product of acid-making); and red oxide and blue and green carbonates from Burra-Burra, Australia. This mix was roasted in an oxygen-rich environment in a large calcining furnace for up to 24 hours mainly to remove a considerable portion of, but not all, the sulfur, which combined with oxygen to form sulfur dioxide. The ores were then quenched with water and pushed through holes in the furnace hearth into bins below. ${ }^{153}$

In the next step (2), smelters fused the mix in an "ore furnace." In general, smelter operators wanted only 7-9\% copper content going into the first furnace to ensure a high slag volume that would remove much of the iron from the melt and ensure the slag was largely copper free. ${ }^{154}$ Smelters took the calcined ore from step (1) and added fresh Class III ores and slag recovered from step (4). This mix was melted in the closed "ore furnace" to keep oxidation down, resulting in a matte output, referred to as "coarse metal," nominally $35 \%$ copper. The slag from this step was discarded, and the metal was tapped into a vat of water to granulize it in preparation for step (3). ${ }^{155}$

The third step (3) was a second 24-hour calcination process to further remove sulfur. The fourth step (4) was the first metallic fusion in the "coarse-metal furnace." This complex step started with calcined granulated coarse metal and added Class IV carbonate and Class V oxide ores, as well as rich slags from the roaster (5), fine metal,

\footnotetext{
${ }^{153}$ Percy, Metallurgy. The Art of Extracting Metals from Their Ores, 322.

${ }^{154}$ Ibid.,327; Napier, "On Copper Smelting," 193. A matte content of 50\% usually resulted in substantial copper remaining in the slag. By the late 1850 s, the Vivians discovered that producing a higher copper content matte would save considerable fuel and that the resultant high-copper slag could be refined in a blast furnace, a system already in practice for a decade by smelters refining Michigan copper.

${ }^{155}$ Percy, Metallurgy. The Art of Extracting Metals from Their Ores, 323-324.
} 
and refinery (6) furnaces. The slag produced in this step, which contained some copper, was returned to the first fusion furnace in step (2), and the metal was drawn off into pigs of "white-metal" that were $75 \%$ copper. ${ }^{156}$

The Welsh called the fifth step (5) "roasting," despite the two calcining (or roasting) steps already accomplished and the melt that occurred later in this step. Here the white-metal pigs were placed in a melting furnace with the doors open and allowed to melt slowly over an eight hour period, fostering oxidation and final sulfur expulsion. Any slag produced was saved and returned to step (4). After slagging, the metal was allowed to cool in the furnace to a pasty mass that emitted, according to Percy, a "frizzling sound" as gases escaped. The furnace temperature was then increased and the copper, now 95\% pure, was melted, slagged, and tapped into pig molds. As it cooled, the copper continued to off-gas, this time leaving a pock-marked surface from bursting gas bubbles in the solidifying metal, giving rise to the term "blister copper." 157

The final step in the basic Welsh process was, as in the Continental system, refining in a reverberatory furnace. Here the blister copper pigs were melted and held for 15 hours in an oxygen rich environment to encourage any last impurities to oxidize. Slag was skimmed and sent to step (4). After 15 hours, the molten surface of the copper was covered with coal or charcoal and poled with a birch or oak log. These carbon sources combined with any lingering oxygen to form $\mathrm{CO}_{2}$ and purified the metal to $99 \% .{ }^{158}$ Overall, the process took several days to complete from the first roast to pure metal.

\footnotetext{
${ }^{156}$ Ibid., 325.

${ }^{157}$ Ibid., 325.

${ }^{158} \mathrm{Ibid}, 325$.
} 
The primary diversion from this process occurred if the initial mix of ores entering the calciner or coarse-metal furnace resulted in a copper too rich in iron, usually $16 \%$ iron to $57 \%$ copper. In this case, the metal had a bluish surface giving rise to its name, blue metal. Blue metal pigs from the coarse metal furnace were fused a second time, pulling the additional iron from the copper with the slag. The slag was collected and returned to the coarse metal furnace (4), and the copper tapped into pigs was sufficiently iron-free white-metal, ready for the roaster. ${ }^{159}$

The 1850s represented the height of the Welsh system, but also saw a significant shift in world development. Part of the success of the Swansea smelters came from the inability of remote mining districts to adapt and perfect complex Welsh copper smelting and refining technologies, thus ensuring a steady ore-import market for southern Wales, even after local sources began to wane. However, just as Cornish ore deposits began to diminish, the first transoceanic electric communication cable kicked off a remarkable increase in demand for copper world wide. This demand would be met largely by new deposits found in the United States.

\footnotetext{
${ }^{159}$ Ibid, 327.
} 


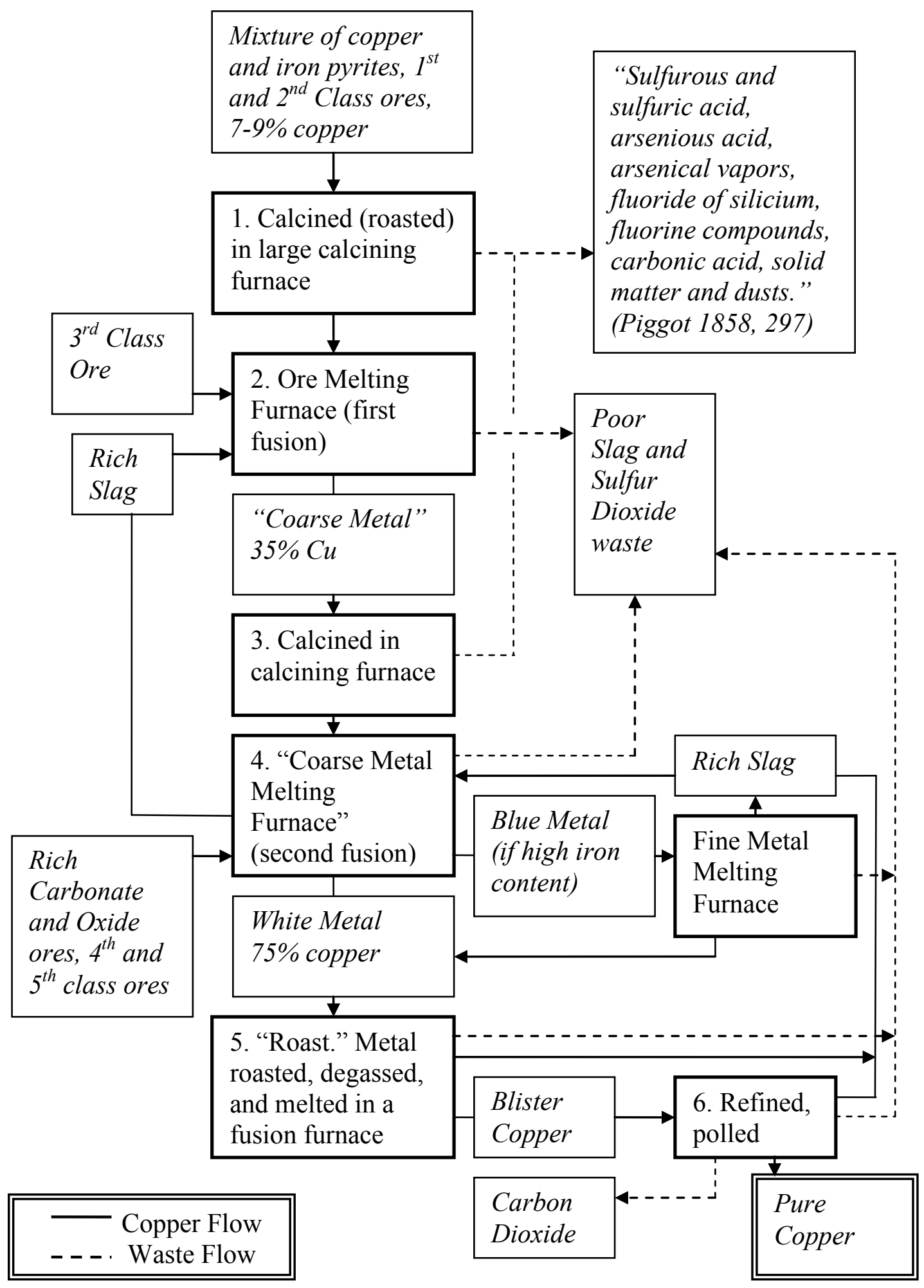

Figure 3.7 Welsh Copper Smelting Process ca. 1850, all reverberatory furnaces. (Source: Author) 


\section{Effects of Copper Smelting in Swansea}

"Delightful Hafod, most serene abode! Thou sweet retreat, fit mansion for a god! Dame Nature, lavish of her gifts we see, And Paradise again restored in thee." 160 -anonymous poet, 1737

"Landore. A spot rich in the renown of its metal and chemical works, but to the casual visitor, ugly with all the ugliness of grime, and dust, and mud, and smoke, and indescribable tastes and odours." ${ }^{161}$

-S.C. Ganwell, 1880

The Welsh were not the first to suffer smelter pollution, but the concentration of works in South Wales created critical environmental, legal, and technical problems far greater than any smelter location had previously witnessed. (See Figure 3.8) Although commentators from Roman times through the $18^{\text {th }}$ century noted unpleasant odors, dead vegetation, and health problems in areas around smelter works, it was not until chronic problems associated with the high output of the Welsh system that communities were forced to address environmental issues of copper smelting. Even Charles Darwin remarked that while visiting Chilean copper mines, "no smoke, furnaces, or great steamengines, disturb the solitude of the surrounding mountains [as at Swansea]."162

Smoke was the greatest environmental concern for smelter communities and nearby farmers. In addition to the chemical composition of the gasses in the smoke described by Piggot (See Figure 3.7), the dusts and solid matters contained toxins and

\footnotetext{
${ }^{160}$ Swansea, A Short History of the Hafod Works, 4 (insert).

${ }^{161}$ Ibid., 4 (insert).

${ }^{162}$ Charles Darwin, Journal of Researches into the Natural History and Geology of the Countries Visited During the Voyage Round the World of H.M.S. Beagle, Eleventh Edition, reprinted ed. (London: John Murray, Albemarle Street, 1913), 276.
} 


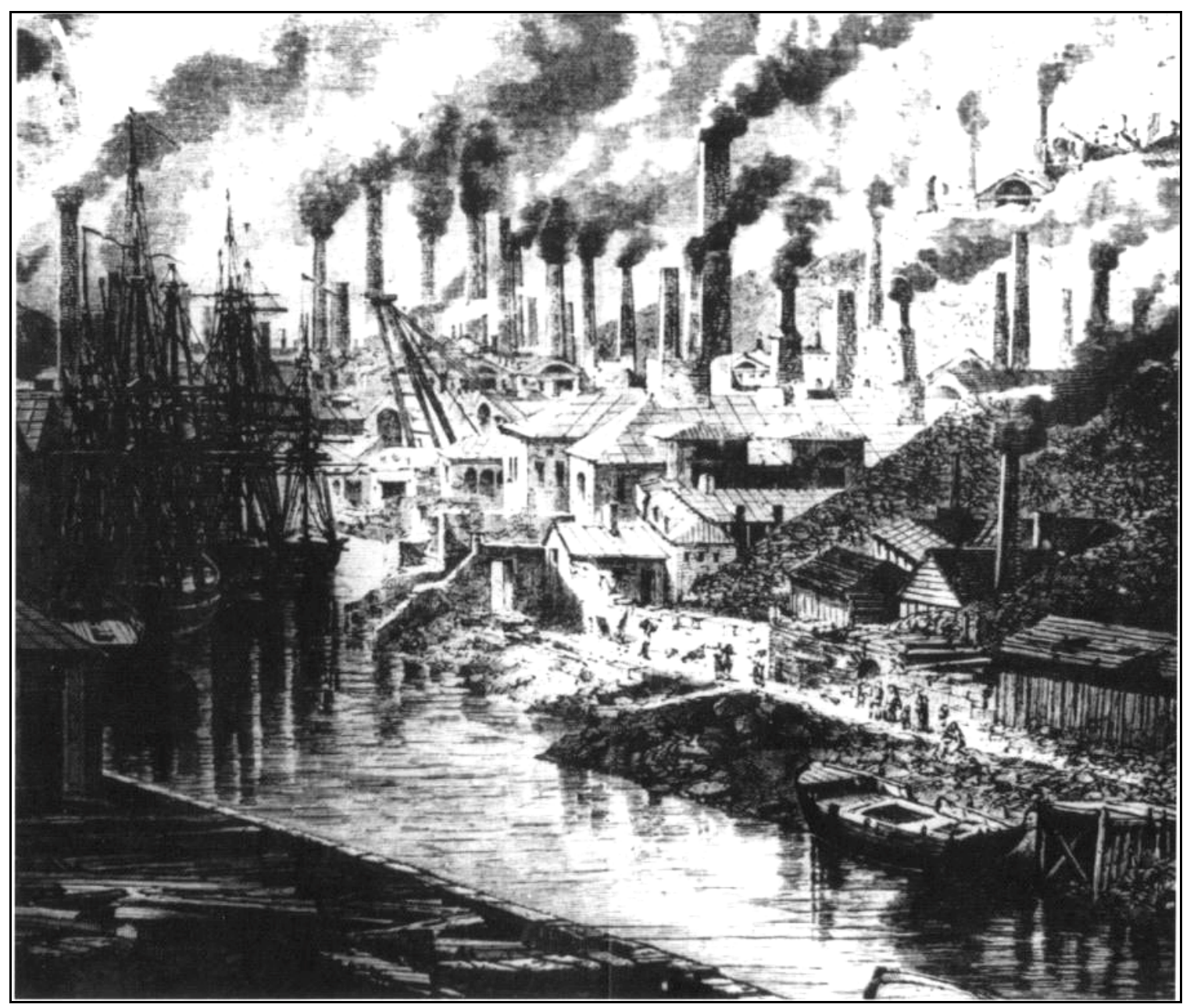

Figure 3.8 Swansea ca. 1860

(After Swansea 2007, 12)

heavy metals, such as copper, lead, silver, antimony, and arsenic, that disbursed with the smoke and settled over wide areas. While the gaseous chemicals formed sulfurous, sulfuric, arsenious, carbonic, and hydrofluoric acids after reacting with moisture in the air, the solids tended to settle on the soil killing plants and being ingested by livestock. ${ }^{163}$

Nineteenth-century health complaints by residents living near smelters included, "a dry sensation in the throat, a bitter, metallic taste in the mouth, loss of appetite,

\footnotetext{
${ }^{163}$ Edmund Newell, "Atmospheric Pollution and the British Copper Industry, 1690-1920," Technology and Culture 38, no. 3 (1997), 660.
} 
shortness of breath, tightness across the chest, smarting eyes, and frayed tempers." ${ }^{164}$ In 1822 Doctors coined the term "metal fume disease" to describe influenza-like symptoms found in smelter workers. ${ }^{165}$ More recent studies have confirmed the risk of acute respiratory diseases and suggested that increased mortality from non-malignant respiratory problems existed in populations working in or living near a primary copper smelter. ${ }^{166}$

Reaction to excess smoke, however, was mixed. Some $17^{\text {th }}$-and $18^{\text {th }}$-century British communities initially resorted simply to zoning smelters outside of town or into an area where prevailing winds would direct the smoke away from population concentrations. Some companies, under the threat of litigation, sought technological solutions or simply bought affected land. ${ }^{167}$ Individuals, however, often resorted to the courts and sued the offending sites for nuisance violations. The primary nuisance in these cases were the "noxious vapors" that caused either injury to property visible in denuded forests, wilted vegetation, failed crops, and sick or dying livestock, or immediate or long-term injury to human health. ${ }^{168}$

The first noxious vapors case was agued in 1608 between neighbors after one opened a pig sty on his property leading to the landmark ruling that stated one should

\footnotetext{
${ }^{164}$ Quoted in Noga Morag-Levine, Chasing the Wind : Regulating Air Pollution in the Common Law State (Princeton, N.J.: Princeton University Press, 2003), 51.

${ }^{165}$ Newell, "Atmospheric Pollution and the British Copper Industry, 1690-1920," 678.

${ }^{166}$ Margaret E. Mattson and Tee L. Guidotti, "Health Risks Associated with Residence near a Primary Copper Smelter: A Preliminary Report," American Journal of Industrial Medicine 1 (1980), 365.

${ }^{167}$ Piggot, The Chemistry and Metallurgy of Copper, 297. Land purchases were likely later $19^{\text {th }}$-century solutions and a practice American smelter companies would employ to avoid smoke and pollution lawsuits in the days before the Clean Air Act.

${ }^{168}$ Morag-Levine, Chasing the Wind : Regulating Air Pollution in the Common Law State, 39.
} 
"use your own (property) so as not to harm another."169 Although this case set a precedent that would stand for 200 years, actual judgments against smelters would generally prove more difficult. The corporation of Liverpool, however, did win one of the earliest successful smelter nuisance cases in 1770. It forced the Macclesfield Copper Company to relocate its smelter outside of town. ${ }^{170}$

Only five of twenty recorded cases, however, resulted in judgments against a smelter company in Britain, mostly in the form of damage awards, although one case resulted in an injunction against further smelting in that location. ${ }^{171}$ One of the more notable failures was a case brought by a consortium of farmers against Vivian and Son's Hafod works in 1834. The farmers claimed that smoke from the smelters destroyed crops, caused health problems, and sickened and killed their livestock by causing "Effryddod" or Welsh crippling disease. The farmers ultimately lost the case because they failed to prove that the Hafod smoke was the primary cause of their problems and not, as the defendants' attorneys argued, poor farming. ${ }^{172}$ A second suit by the same group a year later resulted in a partial judgment against Pasco Grenfell of the Middle Bank smelter works. The judgment acknowledged some damage from smoke, but, because the plaintiffs could not prove exactly what was damaged specifically by Grenfell's smoke, the judge only awarded the farmers a single shilling. ${ }^{173}$

\footnotetext{
${ }^{169}$ Quoted in Ibid., 41.

${ }^{170}$ Edmund Newell and Simon Watts, "The Environmental Impact of Industrialization in South Wales in the Nineteenth Century: 'Copper Smoke' and the Llanell," Environment and History 2, no. 3 (1996), 312.

${ }^{171}$ Newell, "Atmospheric Pollution and the British Copper Industry, 1690-1920," 670-671.

${ }_{172}$ Morag-Levine, Chasing the Wind : Regulating Air Pollution in the Common Law State, 50.

${ }^{173}$ Newell, "Atmospheric Pollution and the British Copper Industry, 1690-1920," 672.
} 
Confusion about the actual health problems associated with copper smoke tended to complicate lawsuits against smelter firms. In 1842 a royal commission report claimed that smelter smoke inhalation posed no adverse health affects, and an 1845 commission reported that smelter smoke had kept Swansea free from the cholera epidemics in the early 1830s. Morag-Levine suggests that there may be some truth in this latter claim as the sulfur- and arsenic-laced smoke may have served as a chemical fumigant and disinfectant. ${ }^{174}$ A questionable 1928 British medical report perpetuated confusion, claiming that smelter smoke was "disinfectant and salutary, although ignorant people have a prejudice against [it]."175 Further, a bath in the sulfurous "yellow-scum covered" quenching water from the first fusion (step 2) of the Welsh smelting process was said to cure mange in dogs. ${ }^{176}$

The smoke also provided a haunting beauty for some. Percy wrote in 1861, "A dense cloud of white smoke perpetually hangs over the copper-works of Swansea and the vicinity, and occasionally beautiful effects are produced in the landscape when the rays of the sun fall upon it, especially towards evening." ${ }^{\prime 77}$ Dr. Thomas Williams of Swansea in an 1854 study titled Report on the Copper-Smoke, its Influence on the Public Health, and the Industrial Diseases of Copper-men wrote that smelter stacks "emit gracefullygyrating, white, smoky, and fleecy columns, which circlingly and wideningly ascend to the upper regions of the atmosphere, there to be lost in the purity of invisible air..."178

\footnotetext{
${ }^{174}$ Morag-Levine, Chasing the Wind : Regulating Air Pollution in the Common Law State, 50-51.

${ }^{175}$ Newell, "Atmospheric Pollution and the British Copper Industry, 1690-1920," 680.

${ }^{176}$ Percy, Metallurgy. The Art of Extracting Metals from Their Ores, 324

${ }^{177}$ Ibid., 335.

${ }^{178}$ Cited in Ibid., 339, as an example of delusional thinking regarding smelter smoke.
} 
Despite a growing recognition of the potential health threats of smelter smoke, however, the economic benefits of smelters to local communities and workers and the general financial gains associated with the copper industry in southern Wales overshadowed environmental and health problems. In 1914, Pyrites, possibly a local company newspaper, wrote “...its sulphurous canopy has transformed verdant hillsides into desert wastes... But the mischief done has been more than compensated by the immense trade "opening" which the copper trade gave to Swansea...But for it the towns on the Tawe would have remained just a popular little bathing creek with a little additional identity owing to its porcelain manufacture..." ${ }^{\prime 179}$ Even more compelling are selected verses from The Song of the Copper Smoke, published in 1871 (cited by Newell) that presaged later legal rulings regarding smelter smoke lawsuits in the United States :

I touched the tall tress with my vapoury hand, And their leaves drop off, like courtiers bland... You may search the vale and mountain high, There is not a flower to gladden the eye.

The widow's lone bosom I thrill with joy, As I fill the hands of her orphan boy, The miner I help in the sunless cave, By me rich merchants their fortunes save, Barristers, bankers, and even clod-hoppers Would feel very small if they hadn't "some coppers."

Thus, not surprisingly, lawsuits brought by individuals or organized groups of farmers often failed to cross the "public nuisance" threshold applied by juries and courts more sympathetic to smelting companies and the economic growth of their

\footnotetext{
${ }^{179}$ Gabb, Lower Swansea Valley Factsheet 7: The Rise and Fall of the Copper Industry, 5. Gabb cited this apologist quote from "Pyrites," likely a company journal or local newspaper.

${ }^{180}$ Newell, "Atmospheric Pollution and the British Copper Industry, 1690-1920," 667.
} 
communities. ${ }^{181}$ Despite the lack of court-orders to desist or pay damages, many people, smelter operators included, knew about and acknowledged the health-hazards posed by copper smoke. Percy quotes John Henry Vivian, of Hafod Works, who stated in the 1820s that the suppression of smelter smoke would be advantageous to the town and neighborhood. ${ }^{182}$ Later, Percy not only acknowledged that all the Swansea smelter owners lived outside of town beyond the reaches of the smelter smoke, but that apologists, such as Thomas Williams (quoted above), who did not accept the smoke as an "unmistakable nuisance [or who] pretend that it is not, must either have a peculiar constitution or lie under some strange delusion." 183

Knowing smelter smoke danger and facing few government restrictions, smelters ultimately handled the nuisance issue in one of three primary ways before going to court. They either did nothing, settled out of court if a case seemed strong enough, or, under a more serious threat of lawsuit or, more often, if the prospect of a financial return on byproducts existed, applied or attempted a technological solution. ${ }^{184}$

The first attempt at by-product recovery from smelter smoke came in the late $18^{\text {th }}$ century from a partnership between John Champion and the Macclesfield Copper Company, the same company that lost the first nuisance judgment against a smelter. John Champion, a descendant of the 1690s Neath smelting works manager, developed a system at a northern Welsh mine site to recover sulfur from initial calcining operations by roasting ore in long kilns, collecting and condensing the smoke, and returning the

\footnotetext{
${ }^{181}$ Ibid., 671.

${ }^{182}$ Percy, Metallurgy. The Art of Extracting Metals from Their Ores, 339

183 Ibid., 339-340.

${ }^{184}$ Newell, "Atmospheric Pollution and the British Copper Industry, 1690-1920," 664.
} 
"cleaned" ore to the mine for sale. While the market for sulfur had yet to fully develop by the $18^{\text {th }}$ century, the process improved the ore quality, lessened the destruction of local vegetation near smelters, and remained a notable component of the Anglesey works in the late $18^{\text {th }}$ century. ${ }^{185}$ Despite this nascent attempt, however, successful and profitable sulfur recovery was still a century away.

The first technological approach with sulfur-recovery-potential processing came from Gossage towers that were successfully condensing and recovering hydrogen chloride from alkali works smoke in the mid $19^{\text {th }}$ century using a cool water spray. The challenge of adapting this water-spray method to copper smelters, however, was the difficulty of combining sulfur dioxides with water. ${ }^{186}$ John Henry Vivian proposed an adaptation of this process in response to an 1821 prize for "obviating the inconvenience arising from the smoke produced by smelting copper ores." ${ }^{187}$ This system used a series of long flues and chambers with water showers to encourage the condensation of sulfur, arsenic, and copper. While this system was only moderately successful and not awarded the prize, the long flue concept, generally combined with a single tall stack, garnered favor. In this arrangement, some, but not all of the by-product toxins precipitated from the smoke before reaching the top of the stack, affording a partial recovery of by-product chemicals. As stack heights increased, precipitate increased, but the taller stacks also

${ }^{185}$ Day and Tylecote, The Industrial Revolution in Metals, 155. Although the Macclesfield smoke case (1770) and the sulfur-recovery process (1778) have been noted by several scholars working with primary materials, none have linked the two. The sulfur-recovery process was located at a mine-site, some distance from Liverpool, but it is hard to imagine that smelting a lower-sulfur ore, thereby reducing the effects of smelter smoke, would not weigh heavily on a decision to partner in a sulfur-recovery process.

${ }^{186}$ Morag-Levine, Chasing the Wind: Regulating Air Pollution in the Common Law State, 48. Sulfur trioxides, on the other hand, easily combined with water to form acid. Creating $\mathrm{SO}_{3}$ from $\mathrm{SO}_{2}$ became the first technological hurdle to acid manufacture from smelter smoke.

${ }^{187}$ Quoted in Newell and Watts, "The Environmental Impact of Industrialization in South Wales in the Nineteenth Century: 'Copper Smoke' and the Llanell," 313. 
dispersed smoke and particulates over a wider area. Despite a decline in the use of tall stacks in the 1830s because of fears of lawsuits from a wider population distribution, they would eventually become a landscape feature synonymous with copper smelters.

Of the available technologies, new furnace designs offered the most promising systems for solving the problem of smelter smoke. Under the right conditions, smelters knew that sulfur dioxides could be oxidized to sulfur trioxides, which combine much easier with water to produce acid in the furnace. The presence of carbon from coal smoke, however, prevented the right reactions from occurring, requiring new furnace designs to separate the coal smoke from the copper gases. But, because the separation in a reverberatory furnace was difficult and expensive, most smelter operators never attempted to install separators, and those that did ultimately abandoned them because of limited success. ${ }^{188}$ In the 1880 s some Swansea smelters attempted using an electrical current passed through the flue to encourage precipitation. ${ }^{189}$ While this technology proved more successful, it was in many ways too late for the British copper industry, which had begun a sharp decline in the 1880 s as major new copper works opened in the United States.

\section{Slag}

Unlike smelter smoke, smelter slag in Swansea was not considered a health hazard. Instead it was regarded as a visual nuisance, a production disposal challenge, or, at best, a minor by-product. Swansea smelters produced copious amounts of "clean

\footnotetext{
${ }^{188}$ Ibid., 315.

${ }^{189}$ Newell, "Atmospheric Pollution and the British Copper Industry, 1690-1920," 678.
} 
slag," the copper-free waste of the melting furnaces. After all, smelters preferred only $9 \%$ copper content in the initial stages leaving over ninety percent of what they processed as waste. Waste slag was not entirely a disposal problem, however, and had some beneficial function. Crushed, it was used for road beds and for new furnace and building foundations. By the $1860 \mathrm{~s}$, molten slag was cast into tiles, slabs, and bricks and used in smelter-building and worker-housing construction, retaining walls, and culvert linings. ${ }^{190}$ Despite some functional uses, slag remained a significant disposal problem as growing "hills of refuse" moved further and further from the works and, when combined with the effects of smoke, created a visually powerful landscape setting. ${ }^{191}$ The often quoted Daniel Webb wrote in 1812, "about a mile or two towards Swansea the appearance is frightful, the smoke of the copper furnaces having entirely destroyed the herbage; and the vast banks of scoriae surrounding the works, together with the volumes of smoke arising from the numerous fires, gives the country a volcanic appearance.” ${ }^{192}$

As previously described, both the German and Welsh systems for smelting sulfides required extensive procedures and multiple steps, indicating a much greater complexity than is often suggested by simple descriptions and diagrams of the system. Often these processes required several alternate roastings and meltings lasting weeks with a variety of ores added at critical times to remove specific waste products or recover valuable by-products before any actual smelting took place to produce matte, black, or

\footnotetext{
${ }^{190}$ Piggot, "The Chemistry and Metallurgy of Copper, " 299, and Hughes, Copperopolis : Landscapes of the Early Industrial Period in Swansea, 53.

${ }_{191}^{19}$ Piggot, "The Chemistry and Metallurgy of Copper," 299.

${ }^{192}$ Newell, "Atmospheric Pollution and the British Copper Industry, 1690-1920," 665. Scoriae is slag.
} 
blister copper. Despite this complexity, global demand for the red metal continued to grow as new industrial uses were introduced and the industry spread beyond its traditional locales despite early German and later British attempts to control the market. Because of the use of the coal, which was significantly cheaper and more plentiful than charcoal, the Welsh process tended to be the most successfully exported technology to newly developing copper smelting areas around the globe. Although German blast furnaces were simpler to build and operate, they tended to be relegated to slag remelting until technological developments significantly increased their productivity. By the start of large-scale American copper production, coinciding with growing industrial demands, the Welsh system reverberatory furnace had come to dominate copper smelting, and most new smelting ventures implemented some version of it.

In many ways the Welsh system developed in Swansea was a transitional industrial one. Lying at the end of 5000 years of traditional production and traditional markets, it turned copper into a global commodity before giving way to modern demand and ever increasing technological sophistication. Its technological systems were new, but its markets, at least initially, were not. On the world stage, it only lasted a short time and only a few key features persisted. Soon the complex ore mixes and multiple furnace types were gone, especially as new techniques were developed to handle very low-grade porphyry ores first in the United States, then around the world. But the elements that persisted included the reverberatory furnace, the tall smoke stack, and environmental degradation. 
Pollution problems associated with southern Welsh smelting highlighted the potential dangers to human health and property. The idea of environmental degradation became codified in contemporary literature describing the Welsh system, and in many ways, was transferred with Welsh technology and practices to developing copper regions around the world. Initially, as in Wales, the economic benefits of copper smelters often overshadowed their environmental problems. In the United States, for instance, most early large-scale copper mining and smelting occurred in the remote, sparsely populated, and largely "under-regulated" West. Attempts to limit pollution did not occur until lawsuits forced the issue, and then the primary solution was for smelter-operating companies to simply purchase the affected land. It would take the 1970 Clean Air Act to formally set legal standards for smelter air emissions. That act occurred too late, however, to prevent much of the damage. Growing recognition that smoke, slag, and other chemical releases caused long-term environmental problems forced the United States to "rethink" environmental response and, under the aegis of the federal Superfund program, attempt to clean or at least mitigate the damage caused by smelting among other industrial activities. 


\section{CHAPTER 4. THE AMERICAN SYSTEM}

The continued success of the south Wales smelters stemmed from their ability to tap the increasing supply of ore from a widespread group of overseas producers...Indeed, the smelters played a key demand-side role in the growth of copper mining industries in Latin America, Australia, southern Africa, North America, and elsewhere. However, it was the development of smelting and refining in these... regions which led to a relative decline in British copper production from the 1860s, and an absolute decline from the late 1890s.

- Edmund Newell, 1990 (Copperopolis, 75)

While the principals of the various smelting and leaching processes are for the most part of European origin, and have long been known, modern practice is essentially American and was evolved on this side of the Atlantic.

-Frederick Laist, 1947 (Seventy-five Years of Progress, 126)

There was never a truly American system of copper smelting. After the decline of British copper production and the very short dominance of Chile, the United States became the world's largest copper producer (and consumer) and maintained that lead for nearly a century. Two primary factors drove this ascendancy: the discovery of significant American copper deposits and the adoption and modification of existing European technologies to fit the new deposits. The "Americanization" of the smelting industry was further propelled by the persistent need to overcome high labor costs with automation and by the general growth of large-scale corporations with available capital to foster technological improvements and create significant economies of scale. The scale of operations became increasingly important as rich copper deposits declined and very large deposits of exceptionally lean ores remained or were discovered. These lean ore bodies often contained as little as $0.5 \%$ copper and required ever greater technological improvements to eliminate up to $99.5 \%$ waste and further reduce labor and processing costs to make the extraction and production of such lean copper ores economically viable. 
In fact, complex copper smelting would only succeed when enough capital existed to invest heavily in technologies and adapt those processes to the local geology. Both of

these conditions coalesced in the late $19^{\text {th }}$ century as very large American copper deposits opened, demand significantly increased, and, to disseminate information and encourage innovation, a technical community developed from expanding mining colleges, mining journals, and industry-wide conferences. While technological improvements often led to ever increased production, few engineers at the time considered the lasting environmental effects of such successful metallurgical applications on such lean ores. The elimination of such a high proportion of gangue, or waste rock, on such a massive scale posed not simply a short-term disposal problem for mining companies, but a significant long-term pollution problem for the United States.

This chapter will examine these broad historical and technological trends in American smelting leading to the successful development of mining districts in Michigan, Tennessee, and Montana, and the evolutionary technological and economic changes in smelting required to maintain profitability as ore bodies diminished. It will then look more closely at the three individual regions chronologically and the specific smelting technologies used to exploit their particular copper deposits and then introduce the environmental histories and consequences of their respective smelting technologies.

\section{Smelting USA}

By the late $19^{\text {th }}$ century, the Welsh system in Britain had evolved into a somewhat inflexible process as the availability of regional copper diminished. As we have seen, at the zenith of copper production in Swansea, smelters relied on a variety of ore-inputs to 
maximize the productivity of existing equipment and technologies, but the Welsh industry ultimately failed to adapt new technology to new ore-types as global supplies changed. Several British authors have argued that this inflexibility was at the core of the decline in British copper smelting. Tylecote suggested that Swansea profit margins were so high for the "monopolistic" smelters who set the price for imported ores from underdeveloped nations, that they had no incentive to change their system until it was too late and their own workers had been recruited by those very underdeveloped nations to create a rival smelting industry. ${ }^{193}$ Newell argues that new technologies, specifically in America, significantly reduced the fuel-to-ore ratio, reversing the economies Swansea reaped from its nearby coal fields. ${ }^{194}$ Smelting at or near the source of ore became the dominant regional organization in the industry.

As available ores and the borrowing potential of future growth dried up in Swansea, so did capital to reinvest into new equipment and processes. By the middle of the $19^{\text {th }}$ century, copper mines in Cornwall and Devon had reached the ends of their productivity, and the international regions providing Swansea's other ores, namely Chile and Australia, had adapted matte-smelting and late-refining technologies in an effort to retain a greater portion of the capital earned from copper production. ${ }^{195}$ While the

\footnotetext{
${ }^{193}$ R. F. Tylecote, A History of Metallurgy, Second ed. (The Institute of Materials, 1992), 150.

${ }^{194}$ Edmund Newell, "Copperopolis: The Rise and Fall of the Copper Industry in Swansea District," Business History 32, no. 3 (1990), 91.

${ }^{195}$ In the early $19^{\text {th }}$ century, the adoption of Welsh smelting technology was hampered in Australia and Chile by an inadequate supply of fuel and technical capability. When smelters overcame these difficulties overseas, an industry emerged heavily influenced by the Welsh. Since these nations were primary export nations, however, the industry tended to remain small, whereas the United States, whose rapidly growing demand could be met entirely by its rapidly growing production, tended to innovate to a much greater degree to meet the needs of a rapidly expanding electrical industry. See Peter Bell and Justin McCarthy, "Early Copper Smelting Technology in Australia," Conference paper presented at Third International Mining History Conference (Golden Colorado: 1994) and Luis Valenzuela, "The Chilean Copper Smelting
} 
Swansea industry continued refining some foreign copper matte through the 1960s and became a primary British zinc producer, ${ }^{196}$ ores in general stayed much closer to mines. Further complicating Swansea's dwindling supplies, early and mid- $19^{\text {th }}$ century smelting technologies and business models crossed the Atlantic to the United States where East Coast smelters created a local industry and began competing directly with Britain for South American, Central America, and Cuban ores. In many ways, American dominance in copper smelting began with the opening of Montana copper mines and smelters in the 1880s. The earlier Michigan mines produced relatively pure copper and, although its smelters based their methods on Cornish and Welsh models, ${ }^{197}$ they did not advance the practice mainly because they didn't have to. In fact, Michigan smelters would ultimately adopt new technologies, such as electrolytic refining, only after they had been successfully implemented elsewhere and the economics of local smelting justified it. Tennessee, which also began mining in the 1840s, imported smelting technology based primarily on German rather than Welsh models, but like Michigan did so without significantly contributing to new methods until the turn of the century when radical changes to smelting practice had begun elsewhere

Industry in the Mid-Nineteenth Century: Phases of Expansion and Stagnation, 1834-58, " Journal of Latin American Studies 24, no. 2 (1992), 507-550.

${ }^{196}$ Stephen Hughes, Copperopolis : Landscapes of the Early Industrial Period in Swansea (Aberystwyth, Ceredigion: Royal Commission on the Ancient and Historical Monuments of Wales, 2000), 63. According to Hughes, between 1860 and 1914, 11 of the 14 smelters that stopped producing copper in Swansea were converted to zinc smelters until stiff competition from modernized American, Canadian, and Australian zinc works forced the closure of all but one of them by 1926. The one remaining zinc works, modernized with government funds, continued on until 1960.

${ }^{197}$ Larry Lankton, Cradle to Grave: Life, Work, and Death at the Lake Superior Copper Mines (New York: Oxford University Press, 1991), 62. The chief adaptation to Welsh reverberatory furnaces built to smelt Michigan mass copper was a door in the top to load large pieces. While this could be considered the first step in the Americanization of smelting because it was a significant modification to a known practice, it did not increase the capacity of the furnace, was not replicated in other districts, and merely simplified the act of melting large pieces of copper. 
and local environmental and political conditions warranted it. It was not until the $1880 \mathrm{~s}$ when Montana smelters imported labor-intensive Welsh and German practices and found them costly and impractical for their labor pool and ore-type, that smelter practice significantly changed in the United States. Further, the scale of production with traditional-sized furnaces proved too small for the demands of a rapidly expanding electrical industry and, as richer ores gave way to leaner ones, improved efficiencies had to be reached in order to produce copper economically and meet consumption needs.

\section{Beginnings}

Although the Americanization of copper smelting began in the $1880 \mathrm{~s}$, attempts to create and sustain an American copper industry began as early as 1648. Gary W. Van Lingen, in his 2002 master's thesis, compiled a near-complete list of documented copper smelters operating in the United States from the mid $17^{\text {th }}$ to the mid $19^{\text {th }}$ century. Most of these smelters were located in or near mining regions in Vermont, Connecticut, New Jersey, and Maryland, smelted mostly under contract, and were short-lived or relatively marginal producers due to a lack of sustained ore, difficult transportation, or limited capital. ${ }^{198}$ More successful and heavily capitalized copper smelting emerged first at two Revere Copper Company works in the Boston area, then at the Baltimore and Cuba and

\footnotetext{
${ }^{198}$ Vermont copper mining and smelting rebounded in the mid and late $19^{\text {th }}$ century, continued in some fashion until the mid $20^{\text {th }}$ century, and at times rivaled the output in the Ducktown district in Tennessee.
} 
Baltimore Copper companies in Maryland, and then in some capacity in Belleville, New Jersey, in the mid $19^{\text {th }}$ century. ${ }^{199}$

The pivotal event in the early success of the Boston, Baltimore, and Belleville smelters was the ill-timed formation of the Swansea Smelter Association in 1840 to pool ore purchases to force prices down and control the sale of copper on the open market. ${ }^{200}$ This action, accompanied by a new British tariff on imported ores and American transportation improvements to anthracite coal fields, effectively created an opening in the global market for American smelters who emulated Welsh business models and imported ores from South American, Central American, and Cuban mines to process and sell to a growing U.S. market. Although these were three of the largest non-ferrous smelters operating in the United States in 1860s, between 1866 and 1872 they were all forced out of the smelting business as mine owners in the rapidly expanding Michigan copper district used their political clout, with support from Tennessee mine owners, to obtain tariff protection from the imported ores on which the Maryland and Massachusetts smelters depended. ${ }^{201}$

\footnotetext{
${ }^{199}$ Gary W. Van Lingen, "The Interpretation of Archaeological Remains at the Pittsburgh and Boston Copper Harbor Copper Mining Company's Second Campsite: Evaluating a Structural Component and Its Potential Uses and Contexts" (Master's Thesis, Michigan Technological University, 2002), 160-161. ${ }^{200}$ Otis Young, "The American Copper Frontier 1640-1893," The Speculator 1, no. 2 (1984), 8.

${ }^{201}$ Hyde, Copper for America, 56. While the Boston and Canton (MA) smelters closed for good in 1872, both the Baltimore works and New Jersey smelters would experience intermittent revivals as copper demand and ore prices permitted. The Baltimore smelters closed for good in 1892 (Hyde, 56) and the New Jersey Works in 1934 (Van Lingen quoting Whiteman, 160). Despite the end of smelting, both the Revere Canton (MA) works and Baltimore Canton (MD) works continued as prominent copper-brass rolling and manufacturing mills, both ultimately becoming part of the Revere Copper and Brass Company empire, whose $20^{\text {th }}$ century holdings included operations in Massachusetts, Maryland, New York, Illinois, Alabama, Texas, Michigan, Arkansas, California, Connecticut, and New Jersey. See Isaac Frederick Marcosson, Copper Heritage; the Story of Revere Copper and Brass Incorporated (New York,: Dodd, Mead, 1955).
} 


\section{The American Century}

These early East Coast copper mining and smelting efforts in the U.S., based on emulating European business and technological models, were superseded when significant ore discoveries were made in Michigan and Tennessee in the 1840s, Montana in the 1870s, and Arizona and Utah in the 1890s. From 1883 until the 1980s, the United States led all other nations in copper production and consumption as the rapid development of electricity and electrical applications around the globe coincided with increased capacity in American copper production. In many ways copper smelting in the late $19^{\text {th }}$ and $20^{\text {th }}$ centuries, though dominated by American companies, was an international technology borrowing successful devices and techniques from earlier copper and other metallurgical applications and adapting them to new conditions and new deposits. If the original German and Welsh processes were focused on perfecting a single technological system that could accept varied ore types, the new methods were much more focused on adapting technology to fit the ore. The American system was defined by a much greater technological flexibility, especially as the quality and quantity of the ore changed.

Driving the "Americanization" of smelting technology was the need to both overcome critical skilled labor shortages and profitably process the vast fields of low grade ores once the relatively small, high grade deposits had been exhausted. Lasky's Law stated that each $0.1 \%$ decrease in (copper) ore grade yielded an $18 \%$ increase in reserve size. ${ }^{202}$ After the 1880 s, the most significant new ore bodies consisted of very

\footnotetext{
${ }^{202}$ Ronald Prain, Copper : The Anatomy of an Industry (London: Mining Journal Books, 1975), 272.
} 
large deposits of very low grade porphyries, often less than one percent copper. Even the rich Montana ores, which in the early 1880 s averaged from $25-60 \%$ copper, dwindled to less than $8 \%$ by 1910 , and the pure Michigan multi-ton copper masses gave way to $2-5 \%$ conglomerate and amygdaloid lodes. As the richness of mined ore dropped, technological improvements sustained production until the ore bodies became too lean to mine and process profitably.

The demand-side of this evolution included a relatively new technology: electricity transmitted through copper wires to generate power, illuminate, and communicate. American demand for electricity and copper exploded in the late $19^{\text {th }}$ century, driving the need to find and exploit greater and greater copper deposits. American demand grew so fast in the $19^{\text {th }}$ century that much of the output of the expanding U.S. mines and smelters remained in the country, effectively creating a second global market able to set prices separate from the London Metal Exchange, which had been the prime market for copper traded across the world for centuries. (See Figure 4.1)
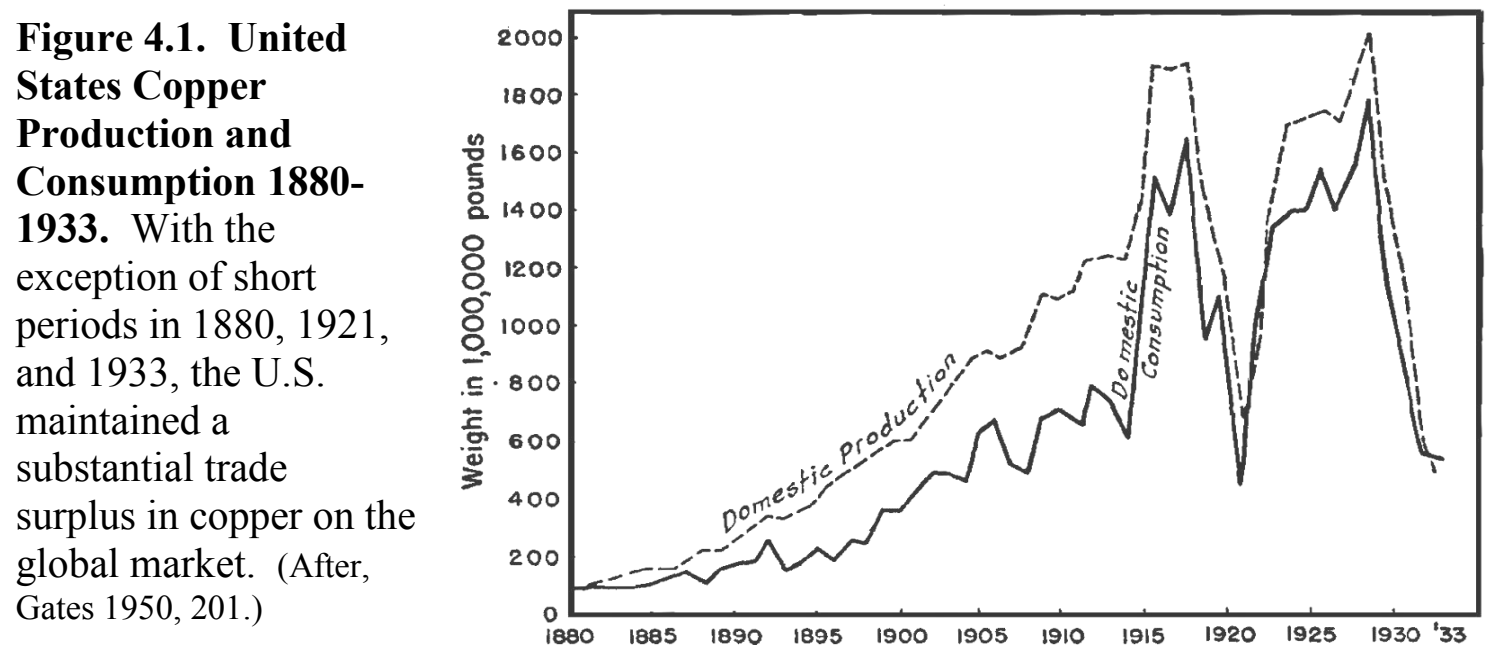
American Smelting Technology

Technology was the key to both increased demand (electricity) and dramatically increased supply. Most early attempts to adapt European smelting technology in the United States were decidedly German, focusing on the blast, shaft, or cupola furnace. ${ }^{203}$ (See Figure 4.2) The blast furnace held several advantages over the reverberatory. Not only did the blast furnace consume less fuel, it was simpler to operate and construct, required fewer laborers, could be run nearly continuously, and operated very similar to furnaces in the substantially larger American iron industry. The blast furnace could handle large chunks of ore, too big for efficient reverberatory smelting, and often required fewer steps to produce copper than the reverberatory. Further, its requirement for cleaner burning fuels than coal because of the direct contact between ore and fuel, a problem for the British copper industry, was easily met by the United States charcoal industry until the adaptation and diffusion of coke. ${ }^{204}$ In addition, cupola-styled blast furnaces were largely portable, could be ordered directly out of a catalog, and were considerably less expensive to operate than reverberatory furnaces.

\footnotetext{
${ }^{203}$ Blast, shaft, and cupola furnaces each operated on the same principal of air forced or "blasted" into the hearth of a fire-brick lined furnace stack. Crews charged the furnaces through a door higher in the stack with copper ores or mattes; fuels of coke, coal, or charcoal; and often a flux. The blasted air provided plenty of oxygen to the burning fuel creating temperatures high enough to melt the metal, waste rock, and flux, which were drawn off through tap holes near the bottom. Blast furnaces were generally fixed to their location on a substantial foundation with no access to the furnace bottom except through the furnace top. Shaft furnaces were the same as blast furnaces, but the term was used initially to describe an Agricola toploaded blast-furnace compared to an ancient mound-furnace, and later to describe cylindrical furnaces when the shape of the "blast furnace" became much larger more rectangular in the late $19^{\text {th }}$ century. Cupolas for smelting copper were initially small cylindrical blast furnaces on pedestal legs with removable bottoms. They were largely portable although by the $20^{\text {th }}$ century, they resembled large rectangular blast furnaces with access to the furnace-bottom from below. Despite these technical differences, the literature from the mid- $19^{\text {th }}$ through $20^{\text {th }}$ centuries often uses the three terms indiscriminately.

${ }^{204}$ Copper: From Mine to Finished Product, (New York: Anaconda Copper Mining Company, 1920), 21.
} 


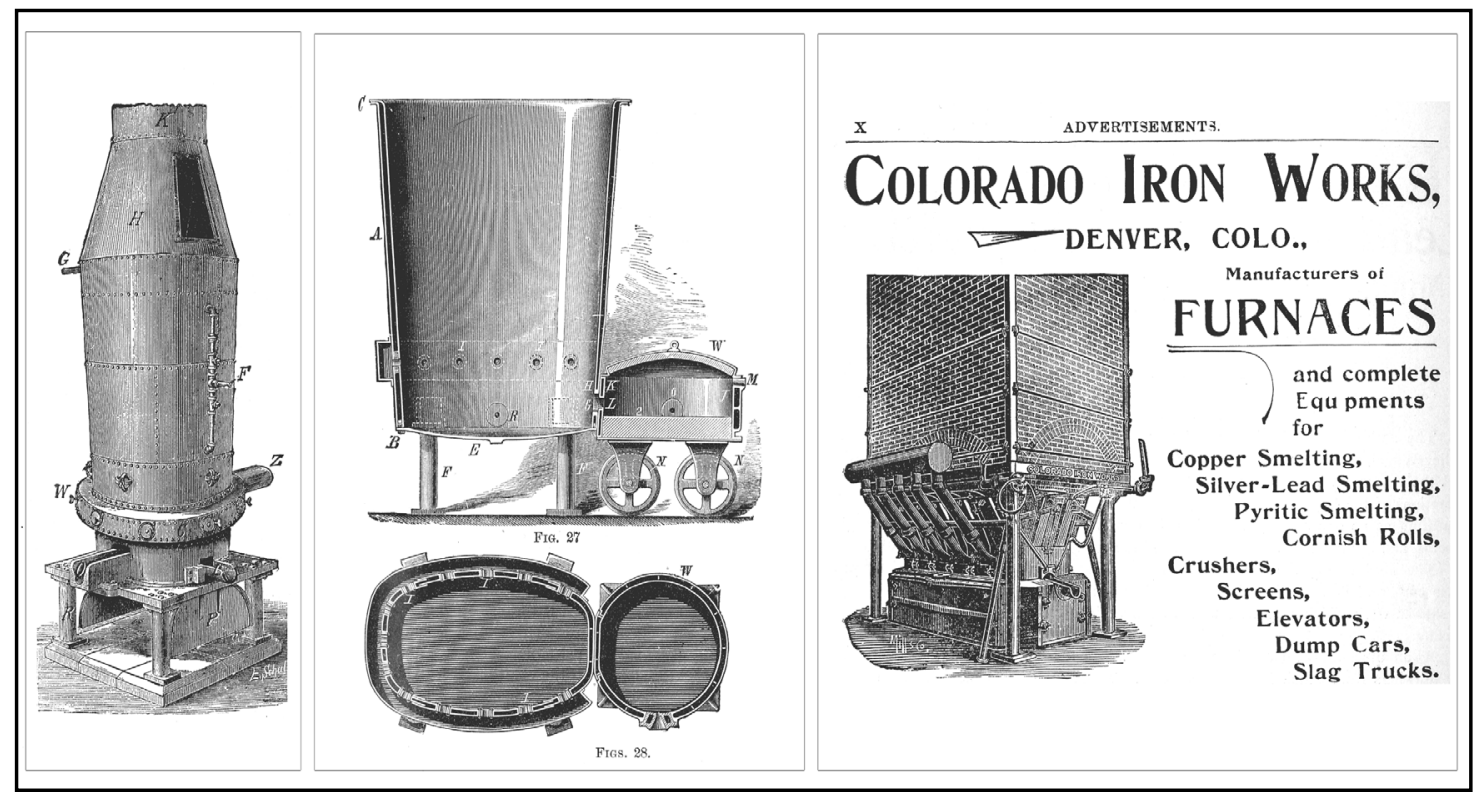

Figure 4.2 Three blast furnace types used in the United States to process copper. Including (from the left) a typical bottom-dropping cupola furnace, an oval Herrshoff furnace that became the prime pyritic smelter in Tennessee after 1900, and an advertisement for a rectangular blast furnace that became the standard blast furnace style used in Michigan and Montana until the 1920s. (After Peters (1908) 267, 265, and advertisement page $\mathrm{X}$.)

The two primary disadvantages to the blast furnace were that it needed to be charged with larger pieces of high-grade ore, and until the late $19^{\text {th }}$ century, it was relatively limited in size which limited its output. As the richness of American ores diminished in mining districts, ore concentration required finer crushing and flotation to recover metals. At this point, blast furnaces became less effective because the dust-sized pieces of ore slipped down though the fuel charge, clogging the hearth, or blew out the stack with the blast. Additionally, wet flotation-concentrated ores reduced the efficiency of blast furnace heat, but had less effect in a reverberatory where the fire was separate from the ores and the hearth was much larger. Briquetting, a process of binding fine ore 
materials into sizes adequate for blast furnaces, often required an additional plant, thus obviating the economic advantage of blast furnace smelting.

Copper blast furnaces were also limited in size. Through the end of the $19^{\text {th }}$ century, the furnaces could not be constructed with a bosh (the furnace hearth where air is added to the heat) wider than 36 " and still maintain adequate air pressure and temperatures required for efficient smelting. Air blasted into the bosh from tuyeres needed to penetrate the mass of materials collecting in the furnace hearth. Too little air and the center of the hearth received less heat, altering the fusion process and at times allowing a set mass to clog up the furnace. Too much air and the temperature nearest the tuyeres would be too high to effect an efficient fusion resulting in greater copper losses in the slag. This deficiency created bottlenecks in production as greater throughput became necessary to maintain economies of scale.

Despite the disadvantages of the $19^{\text {th }}$-century blast furnace, most initial attempts to smelt copper in the United States focused on cost and simplicity and used that furnace type. Of the thirty-two sites Van Lingen identified, he found evidence that, at a minimum, fifteen used or attempted to adopt Continental process blast furnaces. Four used Welsh system reverberatory furnaces, one likely used a crucible furnace, and twelve used unidentified processes. ${ }^{205}$ Van Lingen argued that, in addition to the simpler and less expensive operations of a blast furnace in the early $19^{\text {th }}$ century, experienced German smelter workers were more desirable than British for patriotic reasons, and that they

\footnotetext{
${ }^{205}$ Van Lingen, "The Interpretation of Archaeological Remains at the Pittsburgh and Boston Copper Harbor Copper Mining Company's Second Campsite: Evaluating a Structural Component and Its Potential Uses and Contexts," 160-161
} 
were, until the mid- $19^{\text {th }}$ century, easier to recruit as the German and Swedish copper industries peaked and declined a century earlier than the British industry. ${ }^{206}$ Whatever the choice of smelting method, with the exception of works in New Jersey, Baltimore, and Boston, copper smelters through mid-century usually did not survive more than a few years or make much of an impact on U.S. copper supplies.

While the blast furnace may have been the initial choice of most small-scale copper smelters through the mid- $19^{\text {th }}$ century, the explosion of American copper demand and production in the following decades compounded the need for technological adaptation and advancement using both the Welsh and Continental styles of smelting. To combat the problem of blast furnace throughput, very large and heavily capitalized turnof-the-century American smelters introduced rectangular furnaces with 8'-87' long opposing banks of tuyeres, never reaching distances greater than 57" apart, to get significantly increased capacity while maintaining proper air flow. (See Figure 4.2) Further, relatively cheap and abundant coke from the vast American coal fields replaced charcoal fuel in the blast furnace in the late $19^{\text {th }}$ century, and large, enclosed, roasting furnaces capable of burning off sulfur rapidly reduced the ore roasting step from weeks and months to just a few hours.

In Welsh style smelting, a Detroit reverberatory furnace smelting Michigan copper in the 1870 s operated at a capacity of 10 tons per day, and an early 1880 s reverberatory furnace in Butte produced 15-18 tons of copper per day. By 1901, however, the daily output of a single enlarged and improved reverberatory furnace in

${ }^{206}$ Ibid. 165 
Montana had reached 100 tons per day, and by 1904, 250 tons per day. Early $20^{\text {th }}$

century improvements further increased single-furnace production in Arizona to 600 tons per day. By the 1930s, Arizona reverberatory output had increased to 1600 tons per day per furnace, and by 1949 Canadian furnaces had reached 2000 tons per day. To remain economically viable, each furnace expansion required increased automation and handling controls, but generated considerable fuel economy with no relative increase in labor cost. $^{207}$ (See Figure 4.3)

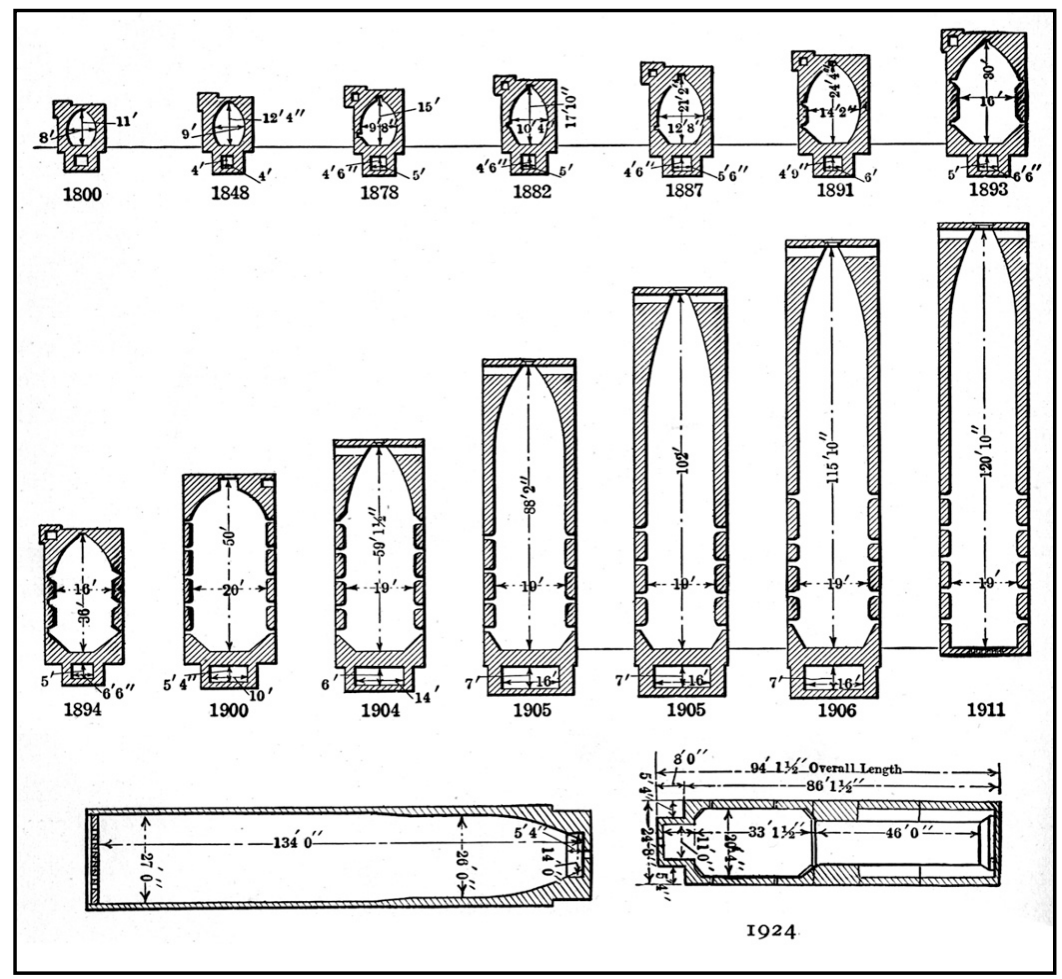
Figure 4.3 The evolution of the reverberatory furnace, 1800-1924. Advances made after 1878 occurred in American mining districts. (After Hofman 1924, 178)

\footnotetext{
${ }^{207}$ N.H. Egleston, "Copper Refining in the United States," Transactions of the American Institute of Mining Engineers 9 (1881), 683; Frederick Laist, "Seventy-Five Years of Progress in Smelting and Leaching of Ores," in Seventy-Five Years of Progress in the Mineral Industry, 1871-1946 (New York: The American Institute of Mining and Metallurgical Engineers, 1948) 129-131; Charles Kuzell, "The Development of Modern Copper Smelting," Transactions of the Metallurgical Society of AIME 218, no. August (1960), 582; Allison Butts, Copper: The Science and Technology of the Metal, Its Alloys, and Compounds (New York: Hafner Publishing, 1970), 89.
} 


\section{Michigan Smelting with Simplified Welsh Technologies}

Historians have argued that processing pure Michigan copper into a molten state should be considered more of a melting process than a smelting process. However, the act of melting pure copper with its attached waste rock in the presence of air tended to change the chemical affinity of the copper for other elements, resulting in a copper-oxide rich compound that required, like all traditionally smelted ores, additional processing to return it to a pure state. Ironically, Michigan copper initially became more contaminated because of the smelting process. Smelting the pure native copper of Michigan's Copper Country, located on the Keweenaw Peninsula, however, would still be a fairly simple process. (See Figure 4.4) After early attempts to adapt Continental style blast and cupola furnaces with poor results, regional smelters successfully modified Welsh reverberatory furnaces to first melt large pieces of mass copper, then adapted the systems to handle much smaller copper particles as the large mass-copper deposits declined. Later, as the copper content of the later ores diminished further, Michigan smelters began incorporating technological advances developed in the Western United States for lowgrade ores. 


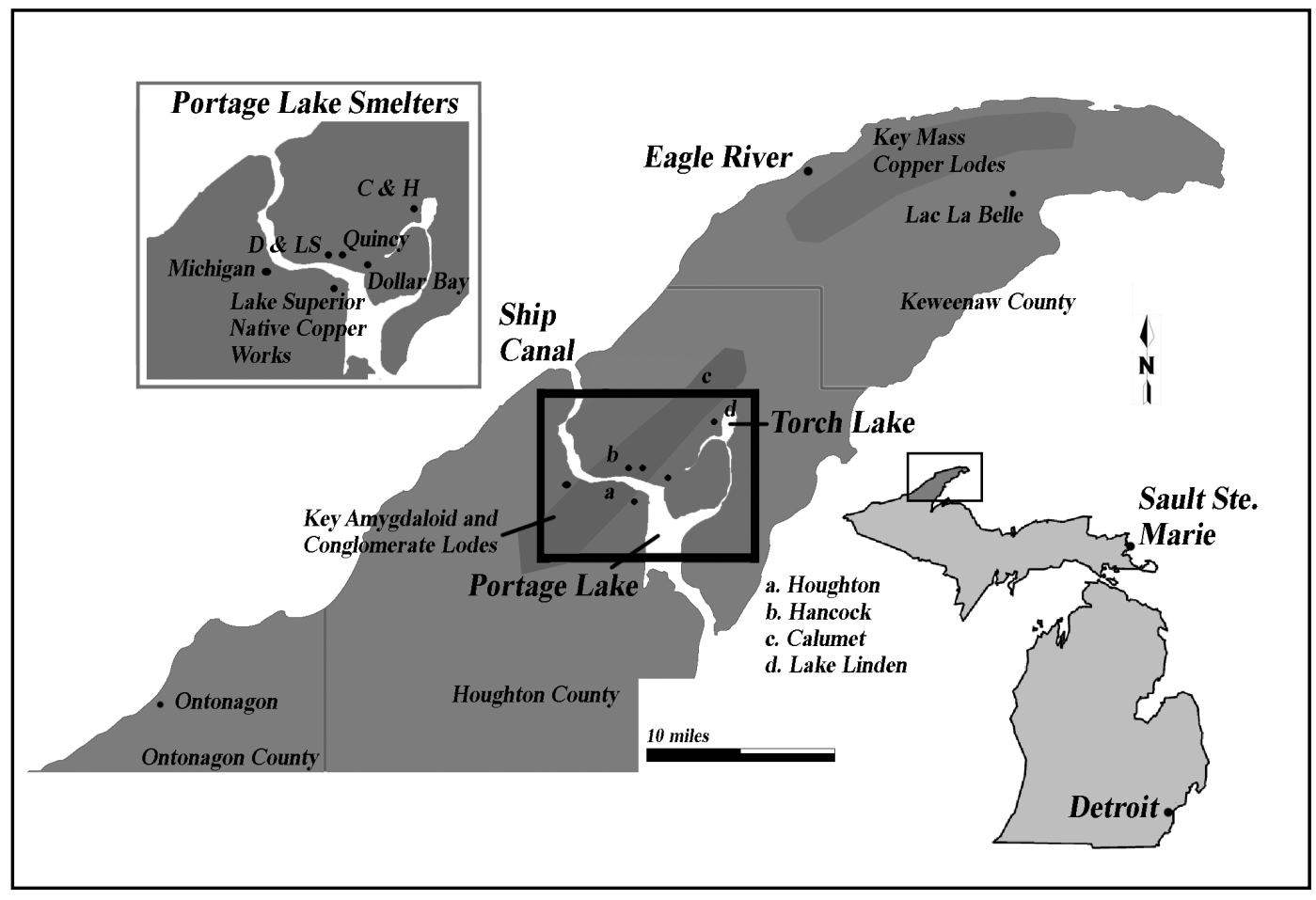

Figure 4.4 Michigan's Keweenaw Peninsula Copper Country (Source: Author)

Mining companies first attempted smelting in Michigan very shortly after the opening of the district in 1844. The region's remoteness and navigational barriers at Sault Ste. Marie created a critical need to establish some sort of localized smelting capability. Not only was shipping on the upper Great Lakes limited to the ice-free months from April to December, but the impassable falls at the Sault required all upcoming goods to be offloaded from a lower-lakes vessel, transported above the falls, and loaded onto one of the few upper-lakes vessels, with the process reversed for copper and south bound travelers. The resultant cost of shipping copper ore from the Keweenaw to Boston smelters in the late 1840 s ran between $\$ 18$ and $\$ 20$ per ton. The cost to ship one ton of ore from Chile to Boston, however, was only $\$ 15$, and just $\$ 6$ to ship the same ton from 
Cuba to Baltimore. ${ }^{208}$ To reduce some of the expense, mines usually built mills to concentrate the rock and remove as much waste material as possible. While in some cases they were able to achieve fairly high rates of concentration, in general the mines still sent considerable gangue south. Despite the high cost of transporting copper rock and waste from the Upper Peninsula, only four documented attempts to smelt ore and fully eliminate excess shipping costs occurred locally before 1860 , and each failed largely because their associated mines failed to produce enough copper or generate enough capital to justify further investment. ${ }^{209}$ Of those four smelters, however, little was recorded beyond rudimentary descriptions of their attempts because neither the smelters nor the mines associated with them developed beyond a season or two. ${ }^{210}$

Meanwhile, the more successful mines sought a smelting outlet for their copper externally. Initially, they shipped large copper masses to the Baltimore and Cuba Company and Boston's Point Shirley Works. To handle the unique multi-ton masses produced by the early Michigan mines, the Baltimore smelter installed a side door on one of its reverberatory furnaces to load large pieces but damaged the lining so much while dragging the copper that the resultant repair costs forced them to withdraw after several

\footnotetext{
${ }^{208}$ William Bryam Gates, Michigan Copper and Boston Dollars : An Economic History of the Michigan Copper Mining Industry, Studies in Economic History (Cambridge: Harvard University Press, 1951) 4, 202,216 . At the time, copper sold for between $\$ 0.18$ and $\$ 0.22$ per pound or $\$ 360$ to $\$ 440$ per ton, but the total cost to set up production and actually produce copper withheld the first dividends until 1849 and then by only a single company. Only two companies paid dividends between 1854 and 1861 .

${ }^{209}$ Larry D. Lankton, Beyond the Boundaries, 119.

${ }^{210}$ The Albion, Suffolk, and Isle Royale and Ohio mines and the Pittsburgh and Boston Company all attempted early smelting without success. See James B. Cooper, "Historical Sketch of Smelting and Refining Lake Copper," Proceedings of the Lake Superior Mining Institute 7 (1901), 44; Charles T. Jackson, "Geological and Mineralogical Report," ed. United States Senate (Washington D.C.: 1849), 443444; Patrick Martin, "Technical Report on the Archeological Survey of Isle Royal National Park," (Houghton, MI: Michigan Technological University, 1986), 15; and Donald Chaput, The Cliff; America's First Great Copper Mine, (Grand Rapids, Mich.: Sequoia Press), 18.
} 
trials. $^{211}$ The Point Shirley works discovered it needed to cut the large mass pieces, an expensive and time consuming task, before charging them into its blast furnace. The extra labor generated a smelting fee of an astonishing $\$ 80$ per ton. ${ }^{212}$ Just a few years later, Detroit smelters would charge less than $\$ 19$ per ton. $^{213}$

Prompted by the failure of early Keweenaw smelters and the expense of East Coast smelting, two individuals affiliated with Michigan copper mining successfully developed refining methods a little closer to the Keweenaw using reverberatory furnaces. The first was C.G. Hussey, a Pittsburgh doctor and partner in the Pittsburgh and Boston's Cliff, the first profitable copper mine in Michigan. Hussey, first successfully smelted a charge in a reverberatory-like "canon furnace" at the Fort Pitt Foundry in 1848, by taking down the side, loading the furnace, and rebuilding the wall. The smelting worked, but was expensive and left a considerable amount of copper inside. Hussey's second experiment, to suspended a copper mass inside a shaft furnace by chain, failed when the chain broke because of the heat and dropped the mass to the furnace bottom, destroying it. $^{214}$ Later in 1848 , after hearing reports of a German silver reverberatory smelter with a removable roof, Hussey hired Welsh smelters to build two reverberatory furnaces with removable roofs in Pittsburgh to lower mass pieces in for melting. (See Figure 4.5) Egleston reported in 1881 that the results of the first casts from the new (1848) furnace

\footnotetext{
${ }^{211}$ Egleston, "Copper Refining in the United States," 679.

212 Ibid., 680.

${ }^{213}$ Gates, Michigan Copper and Boston Dollars : An Economic History of the Michigan Copper Mining Industry, 28.

${ }^{214}$ Egleston, "Copper Refining in the United States," 680.
} 
were "in every respect as good as those now made" thirty years later. ${ }^{215}$ Curiously, the second part of the Hussey system, a cupola furnace, resulted from a clandestine operation



Figure 4.5 Michigan Removable-Top Furnace (After Eggleston (1881) Plate II)

in 1851. One night, according to Egleston, a Pittsburgh native absconded with a boat load of slag from one of Hussey's waste piles. After taking it back to an experimental furnace he'd built, the "thief” discovered a significant quantity of oxidized copper remaining in the slag and made an offer to purchase all the waste-material. Although the person ultimately won a short-term contract to treat the slag in a cupola, Hussey, now aware of the process and its simplicity, erected his own cupola at his site that same year and thereafter treated his slags in-house.

${ }^{215}$ Ibid., 681. 
Hussey's successful furnace arrangement, including a cupola furnace to treat reverberatory slag, was ultimately copied in Pittsburgh, Detroit, Cleveland, and even Baltimore. ${ }^{216}$ Not only did the model of a reverberatory furnace for primary smelting and a cupola for slag remelting become the prominent form of processing all Michigan ores for 75 years, but the cupola practice was adopted in Swansea almost a decade after it was implemented in the United States. ${ }^{217}$ Although the Cliff Mine and Hussey's other Michigan investments eventually closed, the smelter company he created in Pittsburgh expanded into copper and other metal fabricating and still operated in $2009 .{ }^{218}$

The second and ultimately more successful smelter operation began in Detroit in 1850. While Hussey succeeded in creating a vertical operation investing in mines, mills, smelters, and eventually rolling and fabrication mills, the Detroit and Waterbury works, under the direction of John Grout, became the leading contract smelter, processing most of the copper from Michigan mines not owned by Hussey’s Pittsburgh and Boston Company. Detroit sat in an ideal location on the primary transportation route from the east coast to the Keweenaw in "a position by which all travel and business to and from the mines must of necessity pass. ${ }^{219}$ In fact all the copper rock shipped out of the

\footnotetext{
${ }^{216}$ Egleston, "Copper Refining in the United States," 681-682.

${ }^{217}$ The first charge into the smelting furnace in Wales usually required a copper content of less than $10 \%$ to ensure a considerable slag to remove iron without much copper oxide formation. Because of this, a lot of fuel was spent heating and melting $90 \%$ waste. With the cupola process, a richer charge could be used in the first fusion in the reverberatory furnace, and the resulting copper-rich slag could be smelted in the cupola. This proved so successful, that John Vivian patented the process in 1859. (See Chapter 3) ${ }^{218}$ Hyde, Copper for America, 24, and Christine E. Davis, "Archaeological Survey and Land-Use History of The Pittsburgh Technological Center Site, Pittsburgh, Pennsylvania," (Survey Report, Pittsburgh: Urban Redevelopment Authority of Pittsburgh, 1989), 26-27.

219 "The Detroit and Lake Superior Copper Co.'s Smelting Works," Detroit Post and Tribune Newspaper 1879, Supplement, 1.
} 
Keweenaw until 1850 sailed right past Detroit en route to smelters in Baltimore, Boston, or Pittsburgh.

Like Hussey, John Grout's first copper smelting experiments began in 1848 with a failed attempt to work a cupola furnace. While the details of this test and the next two years of Grout's work are unknown, existing accounts of cupola smelting demonstrated the particular difficulty of working large copper rock pieces in such a furnace while reverberatory smelting was proving successful. Grout eventually opened the Detroit works in 1850 with financial backing from Waterbury, Connecticut, home to several large brass works having trouble securing a consistent supply of high quality copper

The new Detroit smelting works looked remarkably similar to the Hussey works in Pittsburgh and began smelting Lake Superior copper in the fall of $1850 .^{220}$ Both ran removable-roof reverberatory furnaces for the primary melt and cupola furnaces for refining copper-rich slag, and both groups hired experienced Welsh smelter workers to run their works. ${ }^{221}$ In the early years, the Detroit smelter operated only seasonally and on a contract basis for many of the smaller mines. One month prior to the opening of navigation, workers would start repair and preparation work on the furnaces so that by the time the first vessel of the season arrived, the works would be prepared. ${ }^{222}$ Initially, the Detroit works operated a single reverberatory furnace and one cupola, but doubled in size by $1853 .^{223}$

\footnotetext{
${ }^{220}$ Cooper, "Historical Sketch of Smelting and Refining Lake Copper," 45-46.

${ }^{221}$ Henry D. Conant, "Copper Smelting in Michigan," The School of Mines Quarterly 42, no. 4 (1911), 286.

222 "Wrought in Fire: Story of the Old Waterbury Copper Mill," Detroit News, March 29, 1896.

223 "Detroit and Waterbury Copper Smelting Works," The Mining Magazine 1 (1853), 298.
} 
The three new smelting works on or near the lower Great Lakes in the early 1850s, including a Cleveland site operated by Hussey's brother, proved pivotal to handling the growth of the copper industry that decade. Michigan copper production increased dramatically from 1850 to 1860 rising almost $1000 \%$, then nearly doubling every decade until the turn of the century. (See Table 4.1) However, with the two Hussey sites dedicated to only a couple of mines and the new Park McCurdy smelter in Pittsburgh, and the Baltimore and Boston works securing only modest amounts of

Table 4.1 Michigan Copper Production (After Gates (1951) Table 6, 197198)

\begin{tabular}{|c|c|c|}
\hline Year & $\begin{array}{c}\text { Production } \\
\text { (tons smelted) }\end{array}$ & $\begin{array}{c}\% \text { of } \\
\text { US }\end{array}$ \\
\hline 1850 & 641 & 88 \\
\hline 1855 & 2,904 & 86 \\
\hline 1860 & 6,035 & 75 \\
\hline 1870 & 12,311 & 87 \\
\hline 1880 & 24,869 & 82 \\
\hline 1890 & 50,705 & 39 \\
\hline 1900 & 72,731 & 24 \\
\hline 1910 & 110,882 & 20 \\
\hline 1920 & 80,672 & 13 \\
\hline 1930 & 84,691 & 12 \\
\hline 1940 & 45,198 & 5 \\
\hline 1946 & 21,663 & 3.6 \\
\hline \hline
\end{tabular}

Michigan ores, the Detroit works held a virtual monopoly on Lake Superior copper smelting. During that time, it earned a reputation for innovation. Egleston reported: "Almost all the experiments and improvements which have been made in copper refining in the United States since the method was first started in Pittsburg, have been made there."224 By 1861, the Detroit works had expanded to a capacity of nearly 3000 tons annually, capable of smelting roughly half of all Michigan copper and nearly $40 \%$ of all U.S. production. $^{225}$

\footnotetext{
${ }^{224}$ Ibid., 682.

${ }^{225}$ Silas Farmer, The History of Detroit and Michigan; or, the Metropolis Illustrated; a Full Record of Territorial Days in Michigan, and the Annals of Wayne County, 2d ed. (Detroit,: S. Farmer \& co., 1889), 818.
} 
Through much of the 1850s copper mining in Michigan centered on the Keweenaw County mass copper mines with primary shipping out of Eagle River. However by 1860 , copper mining had begun shifting on the peninsula. Reflecting Laskey's Law, as productivity in the mines producing the large mass copper pieces began slowing down, mining efforts significantly increased on the much larger amygdaloid and conglomerate lodes, with copper contents of only $2 \%$ to $5 \%$, found in the areas surrounding Portage Lake in Houghton County, 30 miles south of Eagle River. The companies working the new lodes would ultimately become some of the wealthiest mining corporations of the $19^{\text {th }}$ century. Reflecting the opening of new lodes and transportation routes through the Sault, Michigan production doubled from 1855 to 1860 , then doubled again from 1860 to $1870 .{ }^{226}$ (See Table 4.1)

The success of the Hussey system implemented in Detroit changed the economics of smelting, especially when coupled with improved transportation and a significant increase in copper production from mines that would ultimately become very stable producers. There was now enough production from the new mines to warrant the capital expense of establishing a local smelter and, with a proven smelting system and much less expensive transportation to import fuel thanks to the opening of the Sault canal and navigation improvements on the Keweenaw, the Portage Lake Smelter at Hancock opened in 1860 with four reverberatory furnaces and two cupolas. ${ }^{227}$ From 1860 until 1867, the Portage Lake Smelter competed with the Waterbury and Detroit for all copper smelting outside of the mines associated with Hussey despite two very short-lived

\footnotetext{
${ }^{226}$ Ibid., 197.

${ }^{227}$ Cooper, "Historical Sketch of Smelting and Refining Lake Copper," 46.
} 
attempts to establish other regional smelting works at Lac La Belle and Ontonagon, Michigan.

In 1867, a significant consolidation occurred in the industry. The Lac La Belle, Ontonagon, Park-McCurdy, Baltimore and Cuba, and Cleveland works had all closed while Hussey's Pittsburgh works slowed as the output of its associated mines declined. At the same time, the two other working smelters, the Portage Lake and the Waterbury and Detroit, merged forming the Detroit and Lake Superior Copper Company (D\&LS) which held a virtual monopoly on Michigan copper smelting for the next twenty years. (See Table 4.2) Despite early economics that favored Detroit because of cheaper labor, fuel, and transportation costs, the Hancock works expanded as its costs decreased. ${ }^{228}$ By 1875, the Hancock smelter operated eight reverberatory furnaces with three cupolas and processed nearly $80 \%$ of the company's work, while the Detroit works operated only four reverberatory furnaces and two cupolas and processed the remaining. ${ }^{229}$

\section{Early Michigan Smelting Technology}

All of the successful smelters processing Michigan copper from 1850 to the $1920 \mathrm{~s}$ followed a system similar to Hussey's original plan. (See Table 4.2) Mass mines shipped large pieces of copper as single pieces (requiring a removable roof smelter) and smaller copper pieces, called barrel work, packed in barrels for shipping to smelters. The growing mines nearer Portage Lake shipped smaller, non-mass copper from

\footnotetext{
${ }^{228}$ Gates, Michigan Copper and Boston Dollars: An Economic History of the Michigan Copper Mining Industry, 43.

${ }^{229}$ Egleston, "Copper Refining in the United States," 685.
} 
Table 4.2

Michigan Native-Copper Smelters 1844-1971

\begin{tabular}{|c|c|c|c|c|}
\hline \multicolumn{5}{|c|}{ Unsuccessful, Small, or Short-lived Michigan-Copper Smelters ${ }^{*}$} \\
\hline Start Year & Company & Location & Closed & Notes \\
\hline 1844 & Pittsburgh and Boston & Copper Harbor, MI & 1844 & Unconfirmed \\
\hline 1845 & Baltimore and Cuba & $\begin{array}{l}\text { Locust Point, } \\
\text { Baltimore, MD }\end{array}$ & 1866 & $\begin{array}{l}\text { Primary ore } \\
\text { imported }\end{array}$ \\
\hline 1845 & Revere and Sons & $\begin{array}{l}\text { Point Shirley, } \\
\text { Boston, MA }\end{array}$ & 1872 & $\begin{array}{l}\text { Primary ore } \\
\text { imported }\end{array}$ \\
\hline 1846 & $\begin{array}{l}\text { Albion Copper } \\
\text { Company }\end{array}$ & Gratiot River, MI & 1847 & Unsuccessful \\
\hline 1847 & Suffolk Mine & Eagle River, MI & 1848 & Unsuccessful \\
\hline 1848 & $\begin{array}{l}\text { Ohio and Isle Royal } \\
\text { Mine }\end{array}$ & Isle Royal, MI & 1850 & Unsuccessful \\
\hline 1850 & Baltimore Copper & $\begin{array}{l}\text { Canton, } \\
\text { Baltimore, MD }\end{array}$ & 1892 & $\begin{array}{l}\text { Primary ore } \\
\text { imported }\end{array}$ \\
\hline 1858 & Park, McCurdy, and Co. & Pittsburgh, PA & 1862 & Short-lived \\
\hline 1863 & Ontonagon & Ontonagon, MI & 1867 & Short-lived \\
\hline 1865 & Lac La Belle & Lac La Belle, MI & 1865 & Unsuccessful \\
\hline 1880 & $\begin{array}{l}\text { Lake Superior Native } \\
\text { Copper Works/ } \\
\text { Houghton Rolling Mills } \\
\end{array}$ & Houghton, MI & $1890 \mathrm{~s}$ & Small, Short-lived \\
\hline \multicolumn{5}{|c|}{ Successful, long-run, Michigan Native-Copper Smelters ${ }^{* *}$} \\
\hline Start Year & Company & Location & Closed & Notes \\
\hline 1848 & Pittsburgh and Boston & Pittsburgh, PA & $1890 \mathrm{~s}$ & C. G. Hussey \\
\hline 1850 & Pittsburgh and Boston & Cleveland, $\mathrm{OH}$ & 1867 & J. G. Hussey \\
\hline 1850 & Waterbury and Detroit & Detroit, MI & 1887 & $\begin{array}{l}\text { Became D \&SL in } \\
1867\end{array}$ \\
\hline 1860 & Portage Lake Smelter & Hancock, MI & 1908 & $\begin{array}{l}\text { Became D \&SL in } \\
1867\end{array}$ \\
\hline 1886 & $\begin{array}{l}\text { Calumet \& Hecla } \\
\text { Smelter }\end{array}$ & Hubbell, MI & 1969 & $\begin{array}{l}\text { Initial D\&LS } \\
\text { partner }\end{array}$ \\
\hline 1889 & $\begin{array}{l}\text { Dollar Bay Smelting } \\
\text { Wks }\end{array}$ & Dollar Bay, MI & 1919 & $\begin{array}{l}\text { D\&LS partner in } \\
1891\end{array}$ \\
\hline 1891 & $\begin{array}{l}\text { Calumet \& Hecla } \\
\text { Buffalo Smelter }\end{array}$ & Buffalo, NY & 1914 & Calumet and Hecla \\
\hline 1898 & Quincy Smelter & Ripley, MI & 1971 & $\begin{array}{l}\text { Quincy Mining } \\
\text { Company }\end{array}$ \\
\hline 1903 & Michigan Smelter & Houghton, MI & 1954 & $\begin{array}{l}\text { Copper Range } \\
\text { Mining Company }\end{array}$ \\
\hline
\end{tabular}

*See Chaput (1971), Conant (1911), Cooper (1901), Egleston (1881), Hyde (1996), Jackson (1849), Martin (1986), and Wilson (2008).

${ }^{* *}$ Each of these successful smelters initially emulated the Hussey reverberatory-cupola system. See Brignola (2006), Chaput (1971), Conant (1911), Cooper (1901), Egleston (1881), Hyde (1996), Trepal (2006), and Wilson (2008). The White Pine copper smelter operated from 1955 to 1997, but processed sulfide ores and resembled more traditional smelting systems outside of Michigan. 
conglomerate and amygdaloid lodes which as fine, milled, or mechanically crushed ore, $70-75 \%$ copper. $^{230}$ The significant impurities in Michigan copper at the time included iron from milling equipment such as stamp shoes, and geologic inclusions of nickel, silver, cobalt, zinc, and lead and eventually arsenic that existed in veins that cross cut later copper lodes. ${ }^{231}$

Mines usually installed milling, or concentrating, equipment almost immediately after they started mining in an attempt to reduce the waste material they would need to transport to smelters. Michigan milling consisted primarily of Cornish stamp mills and rollers that crushed and ground the hard rock and some sort of intensive water-washing to separate the heavier metal pieces from the lighter gangue, resulting in wastes called stamp sands in Michigan and tailings in other parts of the county. In general for the Michigan mines, whose most productive copper ores averaged around $2 \%$ copper, the mechanical concentration process improved the ore's richness in some cases up to $75 \% .^{232}$ Stamp mills were generally located on waterways for two important reasons. First, they required a significant quantity of water to wash, separate, and transport crushed rock through the mill and second, the waterways provided a convenient sink to dump the considerable amount of stamp sands generated after recovering only $25 \%$ of the materials contained in them, of which only $2 \%$ was copper.

\footnotetext{
${ }^{230}$ Egleston, "Copper Refining in the United States," 686.

${ }^{231}$ Henry D. Conant, "The Historical Development of Smelting and Refining Native Copper," Mining Congress Journal 17 (1931), 532.

${ }^{232}$ Lankton, Cradle to Grave: Life, Work, and Death at the Lake Superior Copper Mines, 12, and Laist, "Seventy-Five Years of Progress in Smelting and Leaching of Ores," 127. Compared to other types of copper smelting this is a fairly high number. Welsh sulfide smelting required a higher waste content to maximize slag to remove iron and minimize copper loss. Smelters generally wanted less than 10\% copper content entering the furnace. (See Chapter 3.)
} 
Following milling, the concentrated rock traveled to one of the contract smelters through the $1880 \mathrm{~s}$ and $1890 \mathrm{~s}$, but in the $20^{\text {th }}$ century it was likely to go to a captive smelter of one of the mining companies. Initially smelters fired reverberatory furnaces with wood, but by the 1880s, like the Welsh, they used bituminous coal shipped in on vessels that would ship out finished copper. However, unlike the traditional Welsh process that included multiple reductions and fusions, and refining, the Michigan process only required a single fusion in the melt stage and a single reduction during the refining stage. Most of the conglomerate and amygdaloid smelters were side charged with ore and rich slag between 12 and 30\% copper, limestone flux, and black copper (oxide) obtained from the cupola furnace. Slag, mostly removed during the fusion stage, included the limestone, ore gangue, portions of the firebrick lining, impurities that could include nickel, silver, cobalt, zinc, lead, iron, and up to $30 \%$ copper oxide.

After slagging, smelters rabbled the molten bath with 20 foot long iron paddles. Rabbling, essentially the splashing of molten copper inside the hearth with the furnace doors open, encouraged air flow, oxygen absorption, and the oxidation of any remaining impurities that could then be skimmed off the surface as new slag. Unfortunately, molten copper also had an affinity for oxygen, and any time the bath was exposed to air, such as during slagging and rabbling, copper oxides tended to form too. Smelters often coated the copper's surface with charcoal, a pure carbon, to encourage the breakdown of copper oxides by the formation of carbon dioxide.

The final stage, also the reduction stage, involved treating the copper bath with a 10 inch diameter, 15-20 foot green, hardwood pole in the same furnace. The rapid 
combustion of the pole with the furnace doors closed pulled the remaining oxygen out of the copper oxide, leaving behind a pure metal and vented carbon dioxide. Smelters then cast the copper into either ingots for remelting or brass/alloy production, large cakes for rolling into sheets, or rectangular bars for wire and rod manufacture. The rich slag removed from the reverberatory furnace was charged into a cupola, which by the $1880 \mathrm{~s}$ was fired with coke, and smelted. Workers tapped the cupola slag and discarded it, while the copper that converted to a black oxide in the furnace, was tapped, cooled, and recharged into a later reverberatory heat. ${ }^{233}$ (See Figure 4.6)

\section{Captive Smelting}

Although the general technological system for smelting Michigan coppers would remain largely unchanged through the $20^{\text {th }}$ century, except for expanded-capacity furnaces, advanced coal use, and the addition of electrolytic refining, the system of smelting under contract for mining companies or purchasing ores outright began to change in 1886. Out west, Montana mining firms were erecting their own smelters very near mine sites, and the iron and steel, railroad, and oil industries began vertically integrating by purchasing all the components of production. While some contract smelting would continue on the Keweenaw after the turn of the century, the general trend was for mining companies to establish their own smelting works and control the entire process from mining and milling to smelting and refining.

\footnotetext{
${ }^{233}$ Ibid., 897-927.
} 


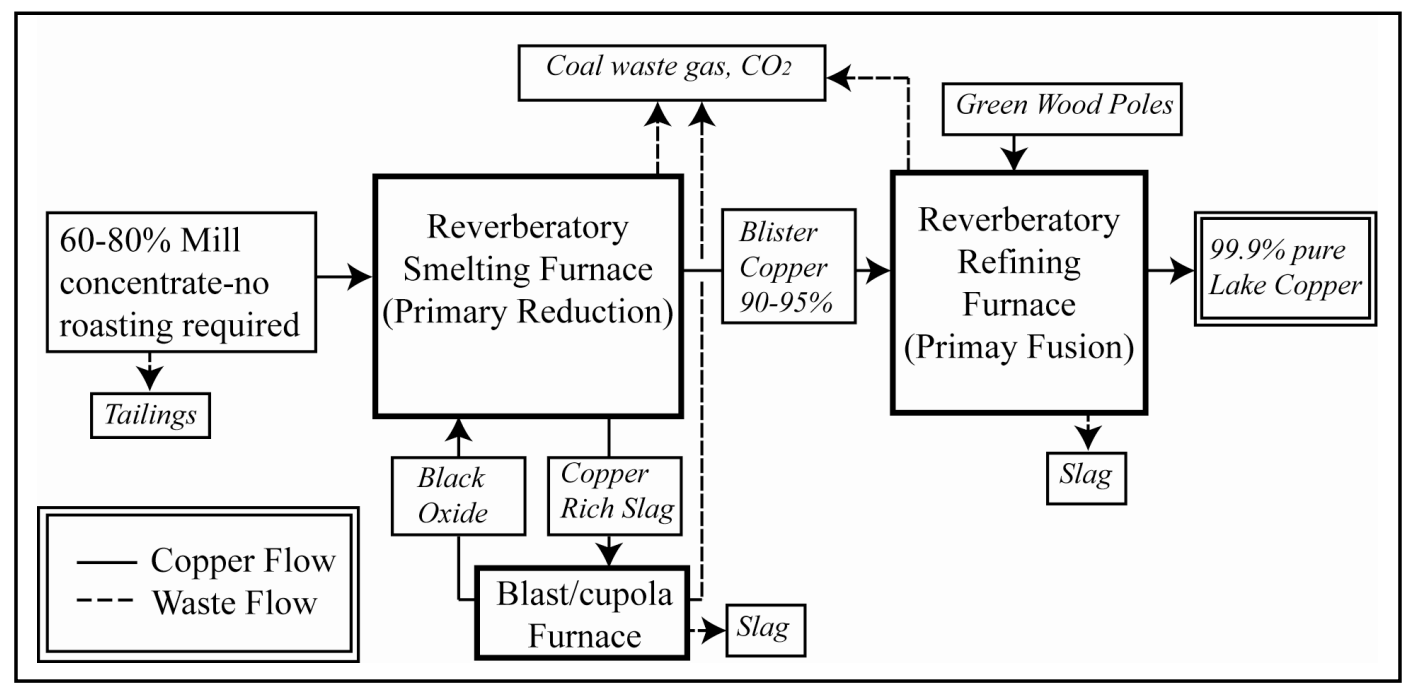

Figure 4.6 Native Copper Smelting Practice on the Keweenaw Peninsula ca. 1910 (source: Author)

The Calumet and Hecla $(\mathrm{C} \& \mathrm{H})$, which began mining as two separate companies on the richest lode in the region in 1865, established the first captive smelter in the area at Hubbell on Torch Lake in 1886. (See Figure 4.4) Constructed initially as a joint venture with the Detroit and Lake Superior smelter, the capacity of the new works ultimately forced the closure of the D\&LS Detroit works in 1887. By 1892, C\&H had bought out the remaining D\&LS joint-venture shares, taking full operational and business control of the Hubbell smelter. With five years smelting experience, $\mathrm{C} \& \mathrm{H}$ opened a second works in Buffalo, New York, to take advantage of lower regional fuel costs and greater electrical capacity. ${ }^{234}$

The Tamarack and Osceola Copper company established the second captive smelter in Dollar Bay, Michigan, in 1889. This small smelter merged with the Detroit

\footnotetext{
${ }^{234}$ Hyde, Copper for America, 54-55, and Gates, Michigan Copper and Boston Dollars : An Economic History of the Michigan Copper Mining Industry, 73.
} 
and Lake Superior in 1891, forming the Lake Superior Smelting Company (LSSC), controlled by the Tamarack, Osceola Consolidated, Isle Royal, and Ahmeek mining companies. LSSC operated its Hancock and Dollar Bay smelters full time through 1903, when the Copper Range Consolidated Copper Company opened the Michigan smelter. By 1908, LSSC had closed its Hancock works, which it had used only provisionally since 1903. Ultimately C\&H took control of the Osceola Consolidated and Ahmeek mines and became the majority owner in the Lake Superior Smelting Company in 1907. The mining company used the Dollar Bay works to smelt the copper of its subsidiary mining interests through 1919 and to experiment with new techniques emerging from the West. $^{235}$

The Quincy Mining Company (QMC), formed in 1846, prospered from 1856 when it discovered the Pewabic lode on its property. It paid dividends to stock-holders in 1862-1864 and then every year from $1867-1920 .^{236}$ By 1910, it had expanded control over the Pewabic lode by purchasing the adjoining Pewabic, Franklin, Mesnard, Pontiac, and Arcadian mines. ${ }^{237}$ The 1891 Pewabic mine purchase included a stamp mill on the shore of Portage Lake and its associated stamp sand dump that stretched several hundred yards into the lake. The Franklin Mine, which Quincy purchased in 1908, operated an adjacent mill and Portage Lake-tailings dump. ${ }^{238}$

\footnotetext{
${ }^{235}$ C. P. Wilson, "A Brief History of Copper Smelting on Portage Lake," Unpublished graduate paper available at Michigan Technological University Archives, (Houghton, MI: Michigan Technological University, 2008), 4-6.

${ }^{236}$ Larry D. Lankton and Charles K. Hyde, Old Reliable : An Illustrated History of the Quincy Mining Company (Hancock, Mich.: Quincy Mine Hoist Association, 1982), 152-153.

${ }^{237}$ Lankton, Cradle to Grave: Life, Work, and Death at the Lake Superior Copper Mines, 72.

${ }^{238}$ Lankton and Hyde, Old Reliable : An Illustrated History of the Quincy Mining Company, 54.
} 
Until 1898, Quincy contracted with the Waterbury and Detroit or one of its subsequent incarnations for all of its mineral reduction. In 1898, after years of discussion, the firm constructed a smelter on land formed by the waste tailings of the Pewabic mill and the recently burned Franklin mill. ${ }^{239}$ Initially, the site included three reverberatory furnaces, a cupola building, and ancillary structures, but shortly thereafter Quincy added a fourth reverberatory furnace. By 1904, a fifth reverberatory furnace with a greater capacity operated on low grade ores in a building attached to the primary reverberatory house. The smelter works was so successful that between 1887 and 1901 , Quincy's per-ton smelting charge dropped from $\$ 15.30$ to $\$ 10.06$, resulting in a $\$ 50,000$ savings in just two years of operation, roughly equivalent to one-third of the smelterconstruction costs. $^{240}$

Quincy Mining Company production peaked between 1909 and 1911 and, despite high profits during WWI, the firm never fully recovered. Through the post-war economic decline and the 1920s, the firm lost money, eventually closing its mines and smelter operations in 1931during the Great Depression. By 1937, the firm had begun processing copper again, and through WWII, with government-set prices, began to see a profit, especially with reclamation efforts, modeled after a C\&H program, to recover copper wasted from earlier, inefficient stamp milling practices with a dredge, fine crushing, and flotation or leaching concentration. Despite an end to Quincy mining in 1945, the smelter continued to process recovered copper until the company's stamp sands

\footnotetext{
${ }^{239}$ Patrick Martin and Gianfranco Archimede, "The Quincy Mining Company Smelting Works, 1898 : Historical Land Use Survey Project," (Houghton, MI: Michigan Technological University 2002), 3.

${ }^{240}$ Charles K. Hyde, "Historic Report on the Quincy Mining Company," (Washington, D.C.: National Park Service, 1978), 174.
} 
were exhausted in 1967, and its contract work, that came after the Michigan Smelter closed in 1948, ended. In 1968, the large number 5 furnace was fitted with natural gas burners and used to melt scrap copper until 1971, when the Quincy chose to shut down rather than abide by new state directives to install pollution controls. ${ }^{241}$

In 1903, Copper Range mining company, with a growing concern about emission controls, hired a Montana firm (with former Michigander Frank Klepetko consulting just after completing the Washoe smelter in Anaconda, Montana) to design an advanced new smelter with a single flue system to vent smoke and gases from the all of its furnaces. While the Quincy smelter largely developed out of a fifty-year smelting tradition on the Keweenaw, the Copper Range adopted a much more contemporary practice and hired outside designers to implement its works. The designers, following a pattern very similar to Montana smelters, arranged buildings on a hillside to take advantage of gravity and eliminate as much labor as possible, and placed the stack at the top of the hill to consolidate smoke effluent. The single stack vented smoke higher in the atmosphere, presumably away from air currents that led into living areas, and allowed for a single dust collection system. The routing of hot gases away from the furnaces also permitted the construction of waste-heat boilers to recover some lost heat, which was often used to create steam to run electrical generators. ${ }^{242}$ This practice was also adopted at Quincy and C\&H. Copper Range operated the Michigan Smelter until the post-war economic decline

\footnotetext{
${ }^{241}$ Martin and Archimede, "The Quincy Mining Company Smelting Works, 1898: Historical Land Use Survey Project," 11.

${ }^{242}$ Trepal, "The Calumet \& Hecla Smelting Works: 1887-2006," Unpublished graduate paper available at Michigan Technological University Archives, Houghton, Mich., 15. The steam turbines powered by waste heat boilers provided enough electricity for C\&H's entire smelter plant needs, and Quincy's generated enough electricity to not only power the smelter, but send additional electricity up to its mines, offices, and residences.
} 
forced its closure in 1948. While the mining company's attention began to focus on a copper sulfide ore lode in Ontonagon County, it continued to mine native copper until 1967, and contracted with Quincy for smelting.

The formation of the Lake Superior Smelting Company in 1891 largely ended the era of private contract smelting in Michigan. Although the Hancock works continued to smelt copper under contract through most of the 1890s and the privately-held Lake Superior Native Copper Works smelted smaller mine batches intermittently through some point in the late $1890 \mathrm{~s},{ }^{243}$ the construction of the C\&H Buffalo works in 1892, the Quincy Smelter in 1898, and the Michigan Smelter in 1903, and the acquisition and later legal consolidation of many of the smaller mines into either the Calumet and Hecla, Quincy, or Copper Range Consolidated Copper companies effectively dealt a death blow to the independent contract smelter. The three consolidated companies came to dominate particular micro regions of the mining district, with each relying on a single regional smelting operation to process its entire copper mineral after $\mathrm{C} \& \mathrm{H}$ closed its Buffalo works in 1914 and the Dollar Bay works in 1919. While a few smaller smelters continued past 1914 , by the end of the decade the mines controlling them would be absorbed by one of the big three and their respective smelting operations shut down.

\section{Captive Smelting Technology}

In general, Michigan copper smelting largely continued to use coal-fired reverberatory furnaces for primary smelting and refining through the end of mining.

${ }^{243}$ Ibid., 7. 
While Quincy remained a fairly conservative company and made few operational changes to its smelter, Copper Range, $\mathrm{C} \& \mathrm{H}$, and LSSC all made substantial changes to their smelting operations to maximize efficiency and take advantage of advancing smelting techniques.

In $1894 \mathrm{C} \& \mathrm{H}$ constructed an electrolytic plant and smelter in Buffalo, likely to take advantage of cheaper Niagara electricity to reprocess rich smelter slags and recover silver from the ore. ${ }^{244}$ The electrolytic process, developed in Europe, involved applying a negative charge to a series of thin pure-copper cathode sheets that then attracted individual copper molecules dissolving off a series of thick, positive-charged 90-99\% matte or blister copper anodes in an acidic bath, resulting in a thick, $99.95 \%$ pure metal cathode. Non-copper materials eventually settled to the bottom of the tank and, if they had value such as silver, could be recovered by processing the "tank-mud." 245 Although the English and German developers attempted to keep their electrolytic processes secret, they had been adopted in the US by 1883 , and three successful electrolytic copper plants operated in Baltimore, and Great Fall and Anaconda, Montana by $1894 .{ }^{246}$ In 1914, C\&H closed its Buffalo smelter plant and moved its equipment and electrolytic works to its Hubbell Smelter. For many copper smelters, especially ones working already pure copper, silver extraction often justified the expense of constructing and operating an electrolytic plant and when the silver content of its ores declined, $\mathrm{C} \& \mathrm{H}$ closed its Hubbell site in 1923 and ended the only Michigan copper electrolysis refining system.

\footnotetext{
${ }^{244}$ Conant, "The Historical Development of Smelting and Refining Native Copper," 532

${ }^{245}$ Hofman, Metallurgy of Copper, 349

${ }^{246}$ Titus Ulke, "Notes on the History of Electrolytic Copper Refining in America," Electrochemical Industry 1, no. 7 (1902-3), 240.
} 
At the Dollar Bay works in 1898, LSSC constructed a large-capacity reverberatory furnace to handle its low-grade ores, but kept its smaller furnaces. It tapped the copper from the melt stage directly into the one of smaller furnaces it now used solely for refining. Ultimately, this sped production, allowing the two processes of melting and refining to continue simultaneously in linked dedicated furnaces. This arrangement was copied by C\&H in Buffalo in 1900 and Hubbell in the 1920s, by Quincy by 1920 , and formed the basic arrangement for the Michigan Smelter design in $1903 .^{247}$

Two coal-based advances appeared on the Keweenaw during the 1910s and 1920s. The first, the use of pulverized coal fuel was the second critical smelter innovation to come out of Dollar Bay. In 1914, based on successes in the cement industry and Canadian copper smelters, LSSC discovered that pulverized coal sped the melting process and resulted in a higher grade of refined copper. ${ }^{248}$ Following the company's lead, the Michigan Smelter constructed a pulverized coal plant in 1921 and $\mathrm{C} \& \mathrm{H}$, in $1923 .{ }^{249}$ Curiously, the Quincy apparently chose not to use pulverized coal, which required on-site production and quick-use to retain the coal's volatility perhaps because the company had little capital to spare for a pulverization plant in the $1920 \mathrm{~s}$.

The second and more significant coal-innovation called for adding coal or coke to the reverberatory charge to create a "slight" reducing atmosphere during the initial

\footnotetext{
${ }^{247}$ Conant, "The Historical Development of Smelting and Refining Native Copper," 532.

248 Ibid., 532.

249 Alessandra Brignola, "The Michigan Smelter at Cole Creek, Houghton: An Introduction," Unpublished graduate paper available at Michigan Technological University Archives, Houghton, Mich., 2006, 7, and Dan Trepal, "The Calumet \& Hecla Smelting Works: 1887-2006," 15.
} 
melt. $^{250}$ While the gangues oxidized in the furnace and formed slag during the melt stage, the coal retarded the copper from oxidizing and joining the slag. ${ }^{251}$ The now "clean" slag came out of the reverberatory furnace without copper oxides and needed no further treatment and the smelters could eliminate their blast furnaces. While it is unclear when or where this process developed, the Michigan Smelter discontinued operating its blast furnace in 1922 and C\&H by the late 1920s. ${ }^{252}$ Quincy also considered eliminating its blast furnace in the 1920 s, but company records indicate that instead of eliminating copper oxide formation with coke additions, it simply reprocessed its copper-rich slag in a reverberatory furnace rather than change processes, and eliminated its blast furnaces. ${ }^{253}$ Quincy tended to keep its smelting processes relatively consistent, but it did increase efficiencies with significant improvements in materials and materials handling. In 1906, Quincy constructed a briquetting plant to combine crushed limestone with low grade ore in a large enough size for smelting in its blast furnace. While this type of process was a critical factor in the continued use of western blast furnaces, it only proved a modest success on the Keweenaw and was largely abandoned within a few years. ${ }^{254}$ More successful was Quincy's addition of a Walker Casting machine in 1920. Until 1920, all copper was hand-ladled out of the furnaces and poured into ingot, cake, or bar molds. The Walker Caster, invented in 1897, permitted Quincy smelter workers to place

\footnotetext{
${ }^{250}$ Endicott R. Lovell and Herman C. Kenny, "Present Smelting Practice," Mining Congress Journal 17 (1931), 534.

${ }^{251}$ Conant, "The Historical Development of Smelting and Refining Native Copper," 532.

${ }^{252}$ Brignola, "The Michigan Smelter at Cole Creek, Houghton: An Introduction," 7.

253 "Quincy Mining Company Annual Report for 1923," (Hancock, Michigan: Quincy Mining Company, 1923)

${ }^{254}$ Martin and Archimede, "The Quincy Mining Company Smelting Works, 1898: Historical Land Use Survey Project," 9.
} 
a variety of empty molds on a rotating turnstile that directed the molds under the tapspout of the Number Five furnace. As the turnstile rotated further, the machine dumped the chilling copper into a water-filled chamber where an electric conveyor transported the copper bars, ingots, or cakes to pick-up areas where workers would deliver them to storage sheds. ${ }^{255}$

\section{A Word about Stamp Sands}

The waste streams from Michigan copper, as with all other significant copper districts, were immense. However, its smelters did not produce excessive sulfur smoke because its ores were relatively clean and did not require extensive chemical processing to recover its metal. Few, if any, lawsuits were filed because of damage to properties, but mill-tailings proved to be a major problem. Ores with copper contents averaging 2-3\% during the peak periods of production meant miners hauled $97-98 \%$ waste up from underground. Milling enriched the $2-3 \%$ copper rock to $60-80 \%$ copper concentrate, with copper companies dumping about $95 \%$ of mine haulings directly into a lake. Later, they recovered it, reclaimed any copper remaining in the tailings, and dumped the now finer sands right back into the lake. This volume does not include poor rock, which is the valueless material that had to be tunneled through underground to get to the ore veins and which was disposed on the surface. Two percent of what was originally mined remained with the copper in the concentrate and was eventually removed from the smelting process as slag. In brief, for every ton of copper produced, 32 tons of tailings and two-thirds of a

\footnotetext{
${ }^{255}$ H. O. Hofman, Metallurgy of Copper (New York: McGraw-Hill, 1924), 276.
} 
ton of slag, on average, were left in the local environment. In 1916, the single year of greatest production, Michigan's copper country produced 13,342 tons of copper, 427,000 tons of tailings, and 8,900 tons of slag. For the period from 1845-1946, the entire Michigan District produced 9.65 million tons of copper, 309 million tons of tailings, and 6.43 million tons of slag, based on an average copper content of $3 \% .{ }^{256}$ A small portion of the total slag resided near smelters in Boston, Baltimore, Pittsburgh, Cleveland, and Detroit, and the tailings numbers do not account for failed mining ventures.

\section{Copper Basin, Tennessee}

Unlike the rather continuous development in Michigan copper, external political conflicts and slack economic development marred and disrupted production in isolated southeast Tennessee through the late- $19^{\text {th }}$ century. The Civil War ended the first phase of regional mining and smelting, and post-war transportation problems ended the second before railroads finally opened the region to large-scale development in the third phase and by-product production propelled the district's growth in the $20^{\text {th }}$ century.

\section{Phase I and II Mining and Smelting}

With the forced removal of the Cherokee Nation in the 1830s, partially initiated by the Cherokee refusal to cede Georgia gold lands to the government, the northGeorgia, east-Tennessee, and western-North Carolina region opened for mineral

\footnotetext{
${ }^{256}$ Gates, Michigan Copper and Boston Dollars : An Economic History of the Michigan Copper Mining Industry, 199-200. The EPA reported an estimated 200 million tons of tailings dumped into Torch Lake alone from the 1868 to 1968. See EPA, First Five Year Report, 2003, p. 11.
} 
speculation and land development. In 1843 prospectors, broadening their search north of the recent gold rush in Dahlonega, Georgia, stumbled onto cuprite crystals in south east Tennessee they initially mistook for gold. ${ }^{257}$ Four years later, a German miner made the first copper ore shipments out of the region to the Point Shirley Works in Boston. ${ }^{258}$ Appalachian copper deposits stretched from Georgia to Vermont but were most prominent and profitable across seven accessible veins in the Ducktown district of southeast Tennessee, also known by the more geologically specific term, Copper Basin. (See Figure 4.7)

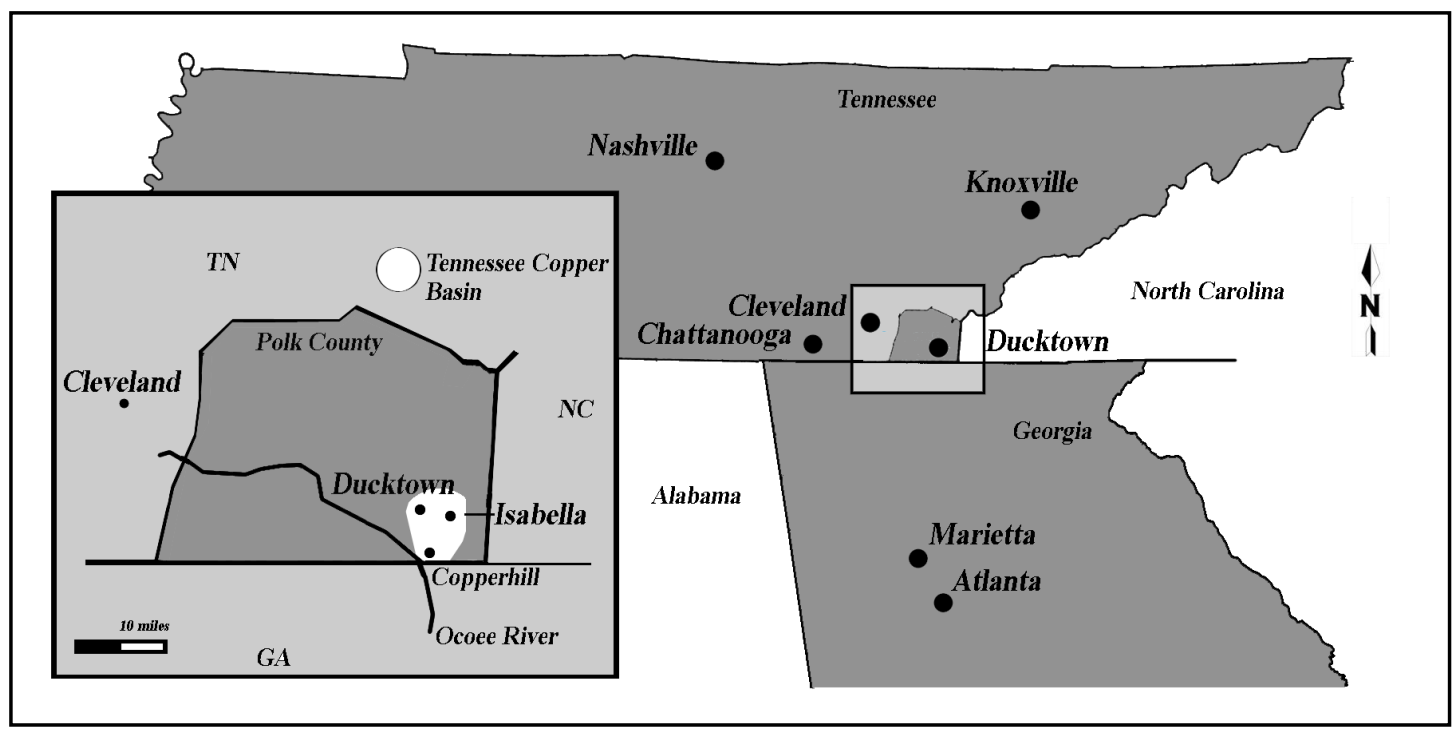

Figure 4.7 Tennessee Copper Basin (Source: Author)

The Ducktown deposits had a traditional sulfide profile with an iron-rich gossan layer covering an enriched oxide layer up to $60 \%$ copper, above a secondary enriched 10 $20 \%$ oxide layer, all sitting over massive $2-3 \%$ iron pyrite $\left(\mathrm{FeS}_{2}\right)$ and chalcopyrite

\footnotetext{
${ }^{257}$ Horace J. Stevens, The Copper Handbook, vol. 10 (Houghton, Mich.: Horace J. Stevens, 1911), 260.

${ }^{258}$ Hyde, Copper for America, 20.
} 
$\left(\mathrm{CuFeS}_{2}\right)$ sulfide layers. Early miners shipped the rich oxide ores to Swansea and Boston smelters profitably, but the secondary layer required an initial local smelting to a $40-50 \%$ copper matte to make the trip out of the district profitable, and the $2-3 \%$ copper massive sulfides would need to be fully smelted and refined locally. ${ }^{259}$

The remote district became accessible when, in 1850, a railroad passed through Cleveland, Tennessee, 33 miles west and investors funded the Ocoee Toll and Plank Road, better known as the Copper Road, from Ducktown to Cleveland in 1853. In 1850, the Hiwassee Company officially started mining. By 1852, three other mines operated in the district and by 1854 , fourteen. ${ }^{260}$ Despite the arduous and expensive two-day ox-cart journey to transport copper ores and mattes out of the district, the region developed, and by 1860 seven smelters operated in the basin. ${ }^{261}$

The few references to Ducktown smelting in the 1850 s indicate primarily charcoal-fired, German-based blast furnaces augmented by reverberatory calcining furnaces and occasional "Welsh or Swansea pattern" smelters. ${ }^{262}$ Despite the consolidation of the 14 active mines into two major corporations following the economic panic of 1857, and an 1860 rolling mill opening in Cleveland, Tennessee, the district could not weather the loss of personnel during the Civil War as young Southerners joined the Confederacy, Northern workers returned home, and investors withdrew operating capital for the duration. From 1861-1863, the Confederacy bought all the copper the few

\footnotetext{
${ }^{259}$ Robert Edward Barclay, Ducktown Back in Raht's Time (Chapel Hill: The University of North Carolina Press, 1946), 61.

${ }^{260}$ Karen Daniels, Tennessee's Historic Copper Basin Area: An Overview (Benton, Tenn: Polk County Publishing, 1992), 3.

${ }^{261}$ Barclay, Ducktown Back in Raht's Time, 85.

${ }^{262}$ Ibid., 67.
} 
open mines produced until the Union Army destroyed the Cleveland Rolling Mill and effectively ended copper production in the district. ${ }^{263}$

In 1866, the two pre-war consolidated companies, the Burra-Burra, named for the recently organized Australian copper district, and the Union Consolidated both reopened with German miner J.E. Raht at the helm of both. Raht also supervised the only remaining independent mine, the Polk County, for a few years after the war before it closed. $^{264}$ Raht hired his brother August to run the smelting complexes that reopened at the Burra-Burra's Isabella and Tennessee mines and at the Polk County mine. At some point in the late 1860s smelting at the Tennessee and Polk slowed down or stopped altogether, and J. E. Raht made a significant investment at Isabella. Not only did Raht build a new refinery in 1871, but he had funded experiments and designs based on an 1866 patent taken out by his other brother William for a Bessemer-style refining process for copper matte. ${ }^{265}$

With dwindling ore quality, climbing fuel prices, and poor/expensive plank road transportation out of the district, neither the Polk County nor the Burra-Burra mine remained viable past $1872 .^{266}$ This left the Union Consolidated in control of the entire output of copper and the only smelter and refining complex at Isabella. Pressing on under Raht, however, the company invested in mining equipment and smelting upgrades,

\footnotetext{
${ }^{263}$ Hyde, Copper for America, 20-21.

${ }^{264}$ Ibid., 20-21, and Barclay, Ducktown Back in Raht's Time., 149.

${ }^{265}$ Many historians believe that William Raht's involvement was in name only and that August Raht actually developed the Bessemer process.

${ }^{266}$ Ken Rush, "Copper Mining Companies of the Basin," Unpublished paper available in Ducktown, Tennessee: Ducktown Basin Museum, 1993, 7.
} 
ultimately settling on a standard of practice closely resembling the German system with American-modified Welsh refining.

\section{Phase I and II Smelting Technology}

Like the Continental system, Tennessee practice used a first roast to expel sulfur. This occurred on an open cordwood bed and, according to one source, produced up to one million pounds of yellow gas per roast. ${ }^{267}$ The first reduction to produce matte took place in "small square blast furnaces" with two tuyeres entering the back wall. The second roast was carried out up to five times to expel sulfur and was followed by a second reduction, this time for black copper. The final reduction occurred in a reverberatory furnace for blister copper, followed by a refining stage in a second reverberatory furnace. All Union Consolidated furnaces used charcoal fuel, but by 1876 both blister and refining reverberatory furnaces were fired with gas, and Raht implemented a compressed air blast into the molten refinery bath to oxidize impurities, emulating the Bessemer process developed by his brother. ${ }^{268}$ (See Figure 4.8)

Part of the reason for the conversion to gas was the enormous quantity of wood consumed for mining, roasting, and smelting in Tennessee. An 1872 visitor to the region reported in the Cherokee Scout (NC) that the fuel consumed by the Isabella smelter reached 60,000 bushels of charcoal per month. ${ }^{269}$ According to a Department of

\footnotetext{
267 "Editor of 1872 Writes About Ducktown Mines," Cherokee Scout (Murphy, NC), September 5, 1935, 4. Although this account was likely accurately reported, it is probably an exaggeration because an Engineering Mining Journal article about the same process a few years later reports an initial roast charge of only 500 tons or one million pounds. (See: Barclay, Ducktown Back in Raht's Time, 151)

${ }^{268}$ Barclay, Ducktown Back in Raht's Time, 151.

269 "Editor of 1872 Writes About Ducktown Mines," 5.
} 
Tennessee Copper Smelting,

Phase II

ca. 1875

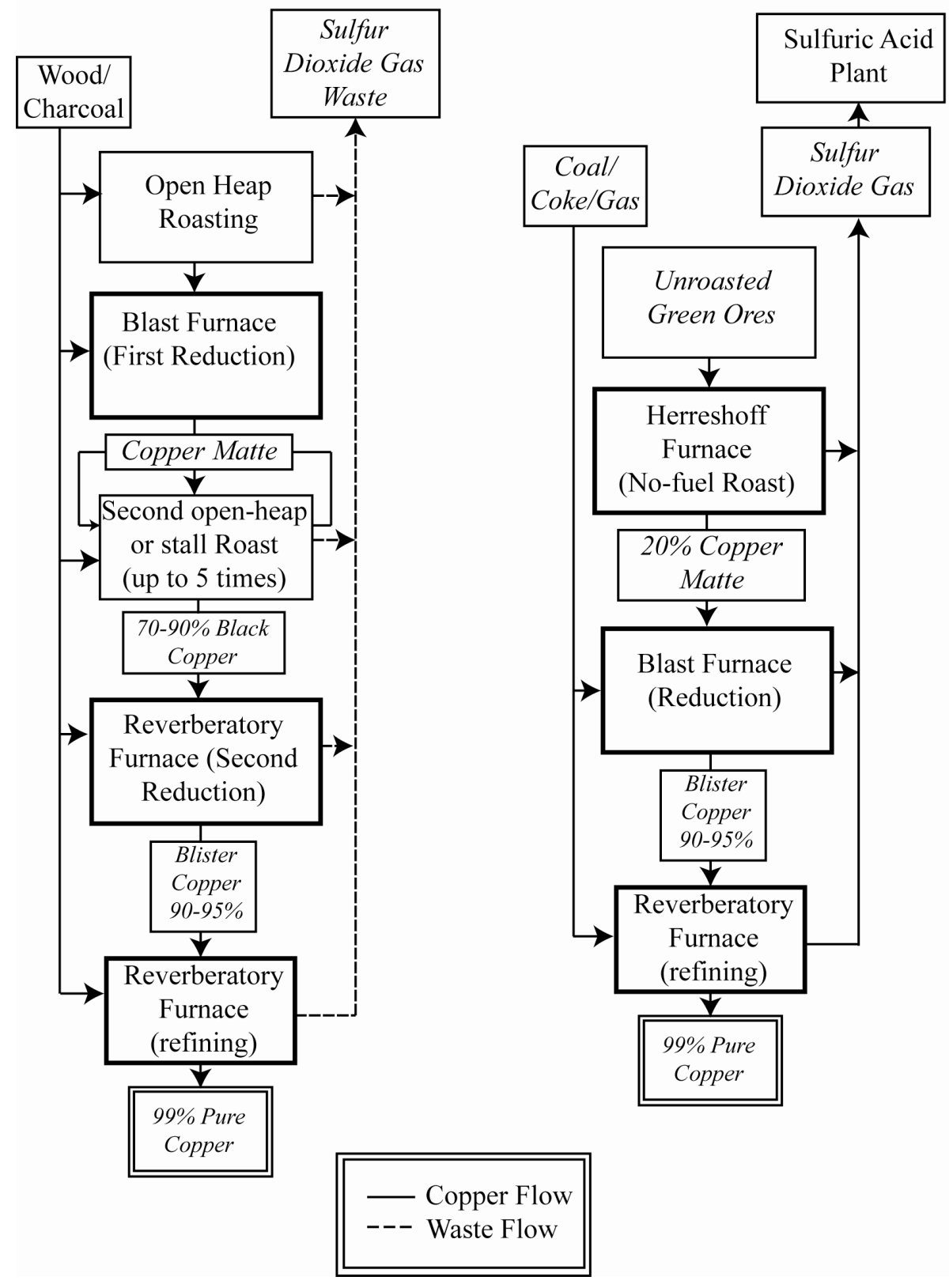

Figure 4.8 Tennessee Copper Smelting Practice (Source: Author) 
Agriculture report in 1875, Tennessee forests averaged between 30 and 70 cords per acre although some dense, old-growth forests could reach as many as $700 .{ }^{270}$ Assuming a charcoal production rate estimated by Gordon and Malone at 50 bushels per cord, a conservative average charcoal consumption of 45,000 bushels per smelter-month, and a typical forest yield of 50 cords per acre, the likely monthly wood consumption per smelter roughly equaled 18 acres of forest land. ${ }^{271}$ Further, estimating the number of smelters running, the district had operated 63 smelter-years by $1878 .{ }^{272}$ At 18 acres per smelter-month, smelting likely consumed a total of 13,600 forested acres or 21 square miles by 1878 . With the basin's size of 36 square miles, not all of which was forested, the region's smelters consumed a significant quantity of available wood which, when coupled with open-heap roasting, mine timbering, building construction, plank-road construction and repair, home heating, and boiler operation, ultimately led to severe timber shortages. Related consumption estimates suggested that mining in total stripped between 47 and 50 square miles of the region for fuel and other uses by $1879 .^{273}$

\footnotetext{
270 "Report of the Secretary of Agriculture for 1875," ed. U.S. Department of Agriculture (Washington, D.C.: U.S. Department of Agriculture, 1875), 291-294.

${ }^{271}$ Robert B. Gordon and Patrick M. Malone, The Texture of Industry: An Archaeological View of the Industrialization of North America (New York: Oxford University Press, 1994), 231. This is a very rough estimate. Some smelters ran reverberatory furnaces which consumed more fuel than blast furnaces; some early furnaces were fired directly with wood which Barclay estimated consumed three-times the amount of cord wood as charcoal; and not all smelters ran their furnaces all the time. Barclay further noted that a single furnace at the Eureka works consumed 300 bushels of charcoal per day, or 9,000 per month. (Barclay, Ducktown Back in Raht's Time, 68) Assuming that each smelter ran an average of five furnaces each day, then 45,000 bushels of charcoal were consumed per site per month.

${ }^{272}$ One smelter operated in 1854 , two in 1855 , three smelters in 1856 , seven in $1860 / 61$, likely three in 1862 , none in 1863, three in 1866-68, two in 1869-71, and one in 1873-1878. Years in between were averaged to come up with 63 smelter-years.

${ }^{273}$ Rush, "Copper Mining Companies of the Basin," 7, Stuart W. Maher, "The Copper-Sulfuric Acid Industry in Tennessee," ed. Division of Geology The State of Tennessee Department of Conservation, Information Circular (Nashville, Tennessee: State of Tennessee, 1966), 4.
} 


\section{Phase III Mining and Smelting}

When we consider what may yet be peering into the possibilities of the future when the locomotive shall appear in their midst, bringing in its trains of coal from Chattanooga or Knoxville, and whilst they are amazed at the timidness of capital which fails to see a golden opportunity, they are yet buoyed up with the hope that ere long their best hopes in this direction will be fully realized. Without a railroad we fear that Ichabod is written upon their unequalled and inexhaustible mineral deposits. ${ }^{274}$

This quote from an 1872 Cherokee Scout article appeared the same year the Burra-Burra mine closed and four years after the Polk County Mine closed. While the Union Consolidated would have its best year in 1878 , it too could not sustain production with the increasing wood-fuel shortages. Despite attempts to lower fuel costs, the Union Consolidated could not continue to operate profitably and, with Michigan production reaching new heights and a greater than 50\% drop in the price of copper since 1872 , the Union Consolidated closed in 1878 , ending all copper production in the district. ${ }^{275}$

In 1890, after more than a decade without copper mining, the north-bound Marietta and North Georgia Railroad built a line to the Copper Basin, meeting the new Knoxville Southern Railroad. With copper prices on the rise since $1885,{ }^{276}$ coal fuel now available, and cheap transportation, copper mining and smelting returned to the district with the incorporation of the Ducktown Sulpher, Copper, and Iron Company (DSCI) in London, England, in 1891 and the Tennessee Copper Company (TCC) in New York in 1899. ${ }^{277}$ DSCI began with the holdings of the former Union Consolidated mining

\footnotetext{
274 "Editor of 1872 Writes About Ducktown Mines,", 6.

${ }^{275}$ Christopher J. Schmitz, World Non-Ferrous Metal Production and Prices 1700 - 1976 (London: Frank Cass, 1979), 270.

${ }^{276}$ Ibid., 270.

${ }^{277}$ Stevens, The Copper Handbook, 746 and 1661.
} 
company that included the Isabella mine and smelter complex, and TCC bought the former Burra-Burra, Polk County, and independent mine holdings.

Shortly after reopening the Mary Mine and the Isabella Smelter, DSCI installed a 100-ton/day coke-fired Herreshoff blast furnace. ${ }^{278}$ (See Figure 4.2) In 1893, it installed a second Herreshoff and by 1901 operated four furnaces and was producing three million pounds of copper annually. ${ }^{279}$ Despite new fuels and equipment, DSCI continued the old practice of open-heap roasting that ultimately posed several significant problems. First, heap roasting methods required several weeks to process an amount of ore that the new blast furnaces smelted in only a few days, creating a significant bottleneck in production. ${ }^{280}$ Second, the sulfuric waste gases from the process quickly dispersed in the basin and killed vegetation in much the same way Swansea smelters did earlier in the century. The Tennessee situation, however, was exacerbated by several decades of rampant timber-harvesting leading to very distinctive, lunar landscape. (See Figure 4.9 and 4.10)

TCC similarly started operations with mining, smelting, and open-heap roasting at the McPherson and Polk County mines near Ducktown in 1901, and by 1903 operated three blast furnaces and more than 150 roasting sheds. By 1906, TCC had consolidated its smelting operations at Copperhill (likely in 1904), operated a five-mile railroad

\footnotetext{
${ }^{278}$ Though of German decent, J. B. F. Herreshoff worked in New York and developed several innovative smelting furnaces and processes based on existing designs and principles. (Peters, Modern Copper Smelting, 266)

${ }^{279}$ Robert Edward Barclay, The Copper Basin, 1890 to 1963 (Knoxville, Tenn.: R. E. Barclay, 1975), 5, and Maher, "The Copper-Sulfuric Acid Industry in Tennessee," 4.

${ }^{280}$ Barclay, The Copper Basin, 1890 to 1963, 5.
} 


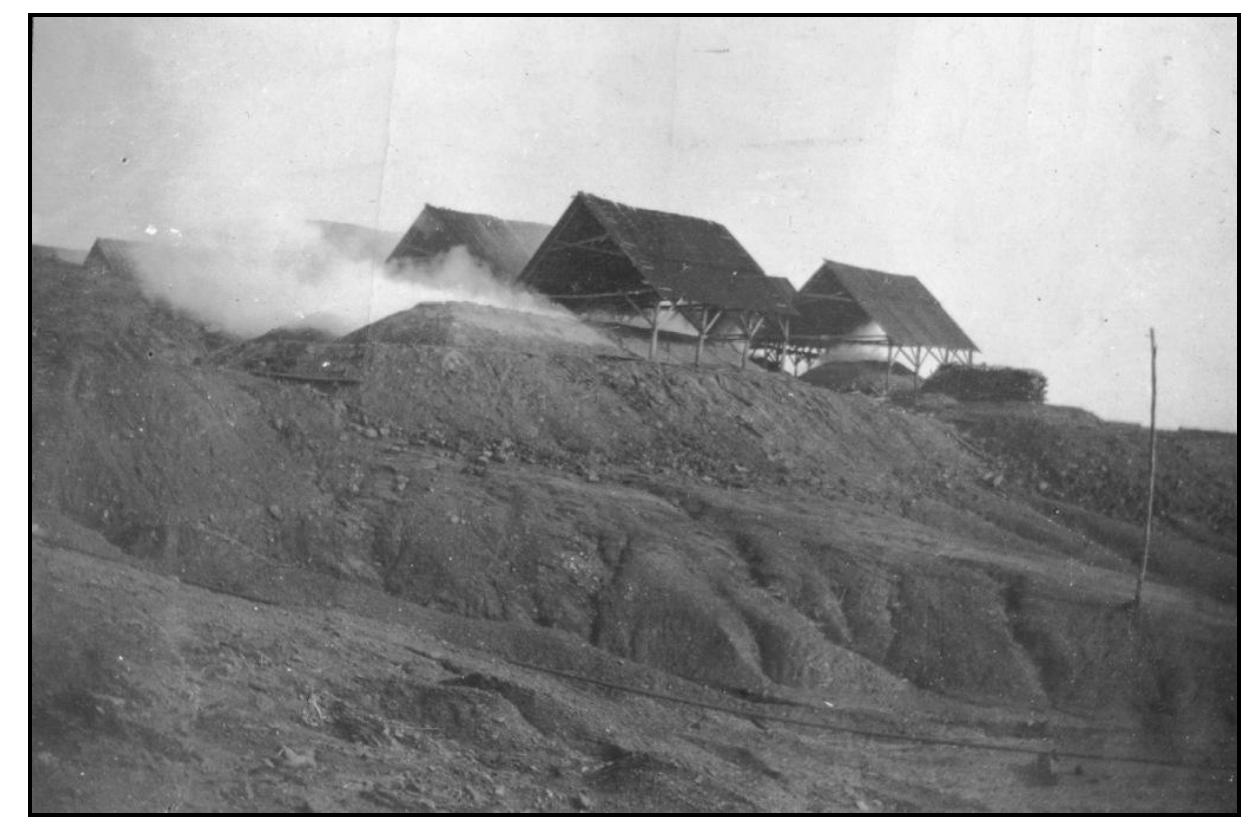

Figure 4.9 Open heap roasting in the Ducktown District ca. 1900.

Large heaps of sulfur-rich copper ores, partially covered, were ignited on a bed of wood and allowed to burn for several weeks as most of the combustible sulfur burns off. (With permission of the Edward Oscar Boak collection, Ducktown Basin Museum.)

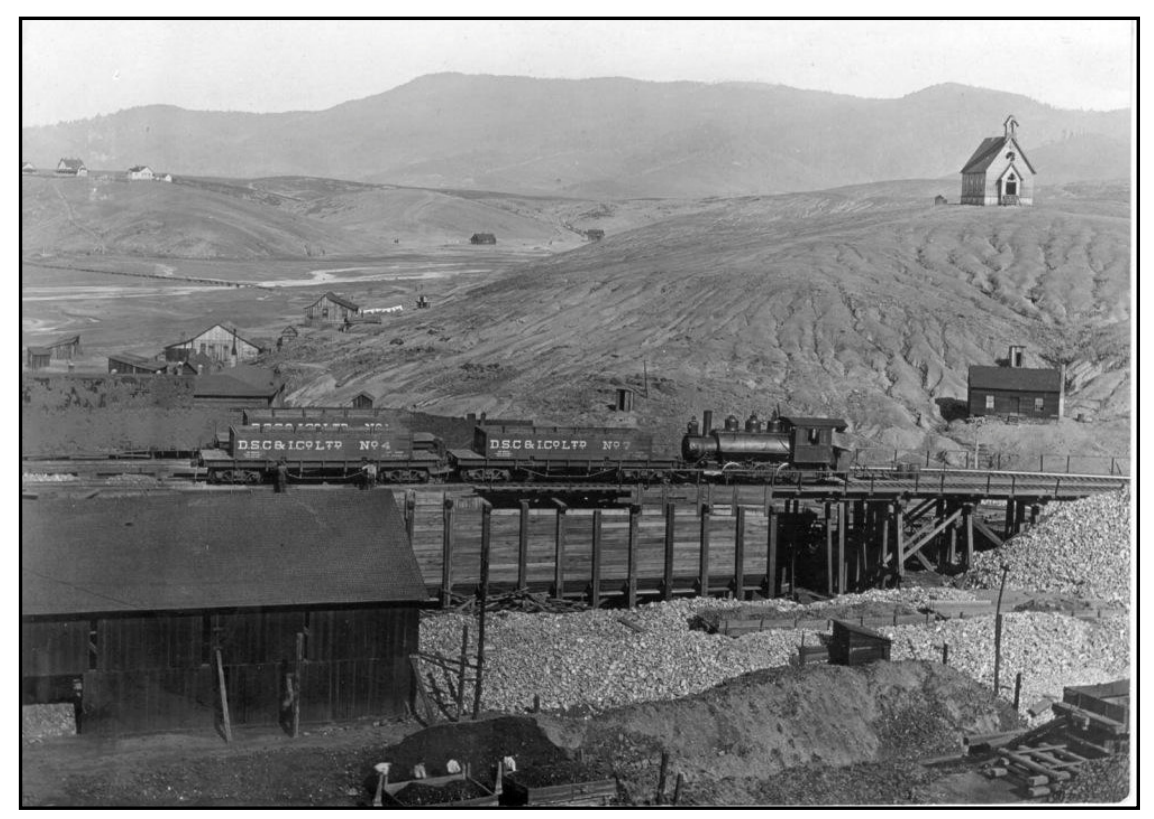

Figure 4.10 Isabella, Tennessee ca. 1920. Effects of several decades of timber harvesting and open-heap roasting have left this once heavily wooded southern landscape completely denuded of any vegetation. (With permission of Ducktown Basin Museum) 
between its smelter and Ducktown mines, and smelted in seven blast furnaces. ${ }^{281}$ Continued open-heap roasting, however, now significantly increased by TCC, proved problematic for local farmers.

\section{Environmental Consequences and Technological Solutions}

Although the issue of smelter smoke had been largely settled in the United Kingdom by the mid $19^{\text {th }}$ century, the impact of expanding American smelter capacity generated new nuisance conflicts between agriculture interests and mining companies in this country. In the first decade of the $20^{\text {th }}$ century, farmers and ranchers filed several lawsuits against Montana, California, Utah, and Tennessee copper smelters. Although R. E. Barclay claimed the State of Georgia brought suit against DSCI as early as 1895, the first well documented court cases began in 1903 and 1904. In both the consolidated Swain v. the TCC \& Cole v. DSCI (1903) case and the Madison v. DSCI (1904) case, landowners lost their attempts to legally end open heap roasting when Tennessee state courts ruled that the mining companies' benefit to the county outweighed their damages. $^{282}$ In the Madison case, the ruling cited 12,000 jobs and a full half of the county's tax income generated by two companies. ${ }^{283}$ In 1906, however, in a much more significant case, the State of Georgia sued TCC and DSCI in front of the U.S. Supreme Court, arguing that its sovereignty over its own land and air was compromised by smoke

\footnotetext{
281 Ibid., 33-36.

${ }^{282}$ A.W. Swain v. Tennessee Copper Co. et al. and Thomas L. Cole v. Ducktown Sulphur, Copper \& Iron Co. Limited, et al., (1903)

${ }^{283}$ Daniels, Tennessee's Historic Copper Basin Area: An Overview, 9.
} 
from Tennessee open heap roasting which killed its farmers' crops. The court ultimately declared an injunction against smoke releases. ${ }^{284}$

Concurrent with mounting environmental protests, both companies sought control over the open-heap roasting problem which, for them, was more of a production flow problem than an environmental nuisance. As early as 1899, DSCI experimented with pyritic smelting, the direct charging of green (unroasted) ores into its Herreshoff blast furnace and using the heat of sulfur and iron oxidation to reduce the ore to a matte, thereby executing two smelting steps in one phase. Since sulfur was flammable and sulfur and iron oxidation generated significant heat, roasting could be sped up in a selfcontained blast furnace by charging smaller amounts and igniting the charge. The combination of retained heat in the furnace and added heat from oxidation and reduction processes in a partial pyritic process meant minimal new fuel was needed. Slag removed the iron oxide, leaving a 10-20\% copper first fusion copper matte which would be cooled, broken up, and re-charged with new ore and flux into a second furnace resulting in a 35$50 \%$ matte that would be sent to refining. ${ }^{285}$

In 1902 DSCI successfully arrived at a workable ore-flux formula and in October, 1903, ended heap roasting altogether and fully implemented partial pyritic smelting of all its ores. ${ }^{286}$ By 1905 , a short time after luring a smelting manager away from DSCI's Isabella works, TCC transitioned completely to pyritic smelting, abandoned all open-heap roasting, and constructed a 325 -foot stack to disperse smoke over a wider area. ${ }^{287}$ Like

\footnotetext{
284 Ibid., 13.

285 Stevens, The Copper Handbook, 664 and 747.

${ }^{286}$ Barclay, The Copper Basin, 1890 to 1963, 6.

287 Stevens, The Copper Handbook, 747, and Barclay, The Copper Basin, 1890 to 1963, 37.
} 
most American smelting innovations, pyritic smelting had its roots in Europe. Sticht reports in Peter's Modern Copper Smelting (1898) that experiments in pyritic smelting dated back to the 1860s in Russia, with significant advances by Englishman John Hollway at Rio Tinto, Spain, in $1878 .^{288}$ Hofman reported successful applications in Montana, Colorado, and Tasmania by $1895 .^{289}$ (See Figure 4.8)

Despite the end of production bottle necks and a symbolic end to open heap roasting, the new methods did not entirely alleviate the smoke problem. In fact, according to Barclay, the problem was exacerbated by an increased density in sulfur dioxide gas, increased output, and new tall stacks that, like Swansea, eliminated smoke locally but with higher air currents, disbursed smoke regionally, ultimately leading to much wider ranging impacts and more distant lawsuits. ${ }^{290}$ In summarizing the majority opinion in the State of Georgia v. TCC, Justice Holmes wrote that Georgia wished:

to enjoin the defendant Copper Companies from discharging noxious gas from their works in Tennessee over the plaintiff's territory. It alleges that in consequence of such a discharge a wholesale destruction of forests, orchards and crops is going on, and other injuries are done and threatened in five counties of the State... But the plaintiff now finds, or thinks that it finds, that the tall chimneys in present use cause the poisonous gases to be carried to greater distances than ever before and that the evil has not been helped. ${ }^{291}$

\footnotetext{
${ }^{288}$ Robert Sticht (Contributing Author), "Pyritic Smelting-Its History, Principals, Scope, Apparatus, and Practical Results," in Modern Copper Smelting, ed. Edward Dyer Peters (New York: The Scientific Publishing, Co., 1898), 400.

${ }^{289}$ Hofman, Metallurgy of Copper, 144.

${ }^{290}$ Barclay, The Copper Basin, 1890 to 1963, 6-7.

${ }^{291}$ State of Georgia v. Tennessee Copper Company and Ducktown Sulphur, Copper, \& Iron Company, 206 U.S. 30 (1907). The other significant event stemming from the 1907 State of Georgia lawsuit was the recognition of environmental damage and the need for some sort of remedy. Karen Daniels suggests that this suit initiated the conservation movement in SE Tennessee. In the 1920s reforestation efforts began in the district and continued into the 21st century. (See Daniels, Tennessee's Historic Copper Basin Area: An Overview 1992, 13) More on this in Chapter 5.
} 
The Supreme Court issued an injunction but postponed enforcement pending the completion of auxiliary sulfuric acid production plants at the smelters that would, in theory, eliminate all sulfur and other poisons from the smoke. As early as 1872, August Raht observed that Ducktown needed an acid recovery plant to stay viable, but sufficient technology did not exist that early. ${ }^{292}$ By the turn of the century, however, several proven European technologies existed, and in the midst of the Georgia lawsuit, DSCI built an experimental, but failed, contact acid plant. By 1909, however, both DSCI and TCC successfully operated chamber acid plants.

Chamber sulfuric acid is produced by the oxidation of sulfur dioxide, obtained in this case by burning sulfide ores in the presence of oxygen, its conversion into sulfur trioxide, and the chemical combination of sulfur trioxide and water to form sulfuric acid $\left(\mathrm{H}_{2} \mathrm{SO}_{4}\right)$. In the three-phase chamber process that includes Glover Towers, Acid Chambers, and Gay-Lussac Towers, nitrogen compounds are used to induce sulfur oxidation through intermediate compounds of nitrogen, sulfur, hydrogen, and oxygen and the subsequent removal of nitrogen compounds from exhaust gases. ${ }^{293}$ Throughout the process, sulfur dioxides are gradually oxidized and eliminated by nitrogen compounds, forming sulfur trioxide and nitrogen-rich gas.

In 1908, TCC built a successful chamber acid plant at Copper Hill, which Stevens claimed was the largest ever built. The system routed blast furnace gases through dust chambers to a "nitrate apparatus" where nitrogen oxides were introduced into the hot gas. The nitrogen enriched gas passed into the bottom of one of two octagonal, 30' diameter

\footnotetext{
${ }^{292}$ Barclay, The Copper Basin, 1890 to 1963, 39.

${ }^{293}$ Andrew Miller Fairlie, Sulfuric Acid Manufacture (New York: Reinhold Pub. Corp., 1936), 13-14.
} 
by 50' high Glover Towers where it encountered a combination of chamber acid and nitrous vitriol, an acid from the Gay-Lussac towers, trickling down from the top. The Glover tower encouraged nitrogen from the nitrous vitriol and steam from both acids to pass into the hot flue gas, thereby concentrating the chamber acid and de-nitrated nitrous vitriol. The combination, now essentially a simple concentrated sulfuric acid, was collected from the tower bottom and reused in the Gay-Lussac Tower. ${ }^{294}$

The partially oxidized sulfur dioxide flue gas, nitrogen compounds, and some sulfur trioxide passed from the Glover Tower through lead-lined flues to a 4.6 million square foot chamber for further oxidizing, hydrating, and condensing. Through the process, the quantity of sulfur dioxide gradually lessened from $7 \%$, as the gases passed through several separate chambers converting to sulfur trioxide, to less than $0.1 \%$ at the Gay-Lussac tower. Water mist was introduced into the chamber top and combined easily with the sulfur trioxide, forming sulfuric acid that condensed on lead sheets and was collected in pans below the chamber and sold. The nitrogen-rich, de-sulfured gases passed from the chambers to one of ten Gay-Lussac Towers that trickled concentrated denitrated sulfuric acid from the Glover Tower downward absorbing up to $86 \%$ of the remaining nitrogen in the up-flowing de-sulfured gas. The now nitrogen-rich sulfuric acid, or nitrous vitriol, was collected from the bottom of the Gay-Lussac towers and used in the Glover Tower to introduce nitrogen compounds to the flue gases. The de-sulfured

\footnotetext{
${ }^{294}$ Ibid., 144-145, and Stevens, The Copper Handbook, 1665.
} 
and now mostly de-nitrated gases passed from the system and were vented into the atmosphere. $^{295}$ (See Figure 4.11 and 4.12)

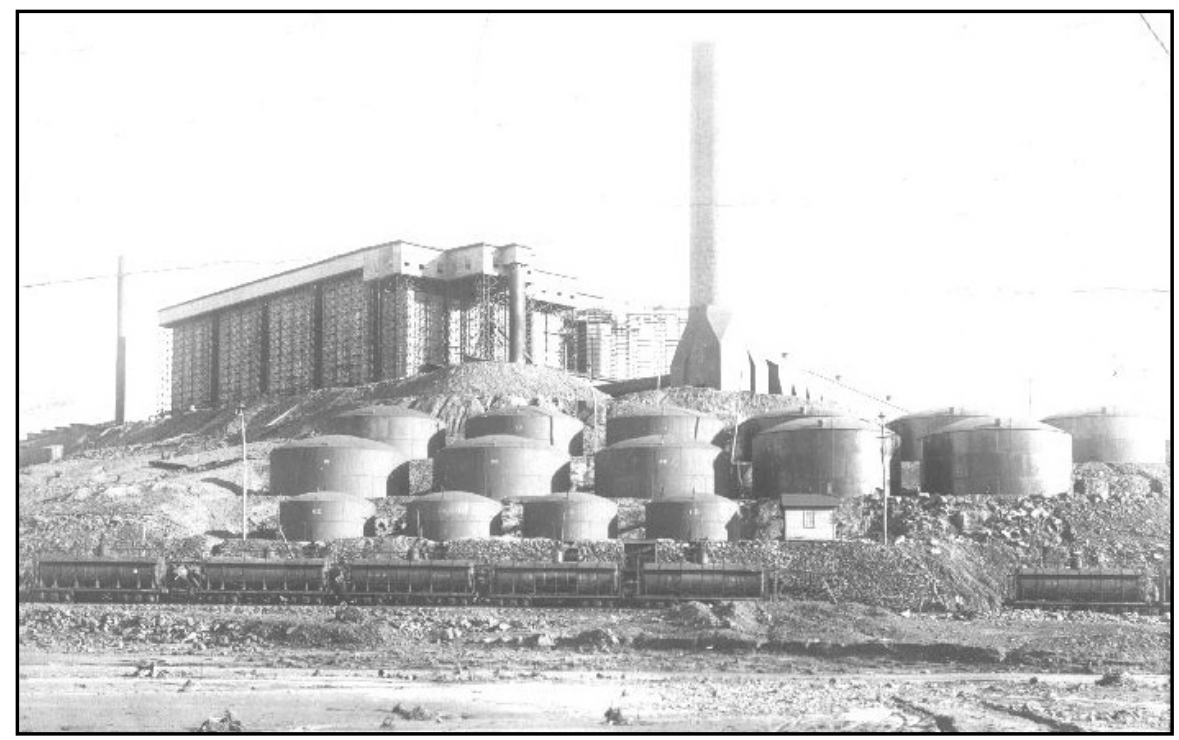

Figure 4.11 Tennessee Copper Company Chamber Acid Plant showing acid-forming chamber facility on the hilltop with acid storage tanks and rail cars in the middle ground ca. 1920. (With permission of Ducktown Basin Museum.)

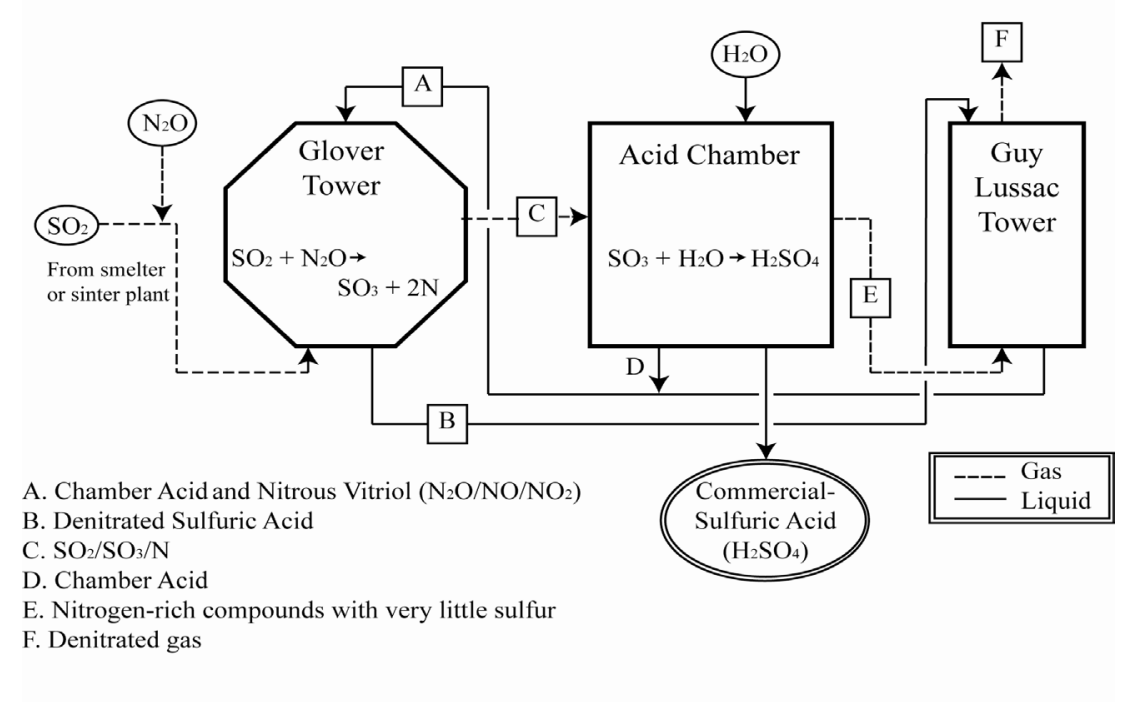

Figure 4.12 Chamber Acid Process for sulfuric acid production as used in Tennessee from the 1910s to 2000. (Source: Author)

${ }^{295}$ Fairlie, Sulfuric Acid Manufacture, 143-145, and Stevens, The Copper Handbook, 1666. 
Although the TCC acid plant was the largest in the world at the time, none of the prime processes had American roots. French chemist Joseph-Louis Gay-Lussac invented the Gay-Lussac tower in 1823 but found little use for his device until it was paired with the Glover tower, invented by Englishman John Glover in $1859 .{ }^{296}$ Both sets of towers were lead-lined structures to keep the acid from deteriorating any structural elements, then lined with fire-brick and packed with flint, coke, broken wine bottles, or any other chemically neutral barrier to slow the ascent of smoke and the descent of acid. ${ }^{297}$ Small lead chambers were first created in England in 1746 for sulfuric acid production with improvements in the late $18^{\text {th }}$ century. ${ }^{298}$ Contact acid production developed in Britain in 1831 for converting $\mathrm{SO}_{2}$ into $\mathrm{SO}_{3}$ by drawing sulfur dioxide and air into a tube filled with heated platinum or later vanadium oxide and causing the oxygen molecules to join the sulfur. $^{299}$

As soon as DSCI's chamber acid plant went into operation, the company made more money from sulfur recovery and acid production than copper, relegating copper to a by-product of acid production. ${ }^{300}$ As soon as TCC's plant went on line, TCC signed a 10- year contract with International Agriculture Corporation for TCC's entire output of sulfuric acid. ${ }^{301}$ In 1909, 53\% of all sulfuric acid was used in agriculture fertilizers, which dropped to $28 \%$ in 1918 when explosives took $36 \%$ and the steel, petroleum refining, and chemical/drug industries used about $9 \%$ each. Through the mid-1930s, the

\footnotetext{
${ }^{296}$ Fairlie, Sulfuric Acid Manufacture, 23-24.

${ }^{297}$ Alfred G. Lock and Charles G. Lock, A Practical Treatise on the Manufacture of Sulphuric Acid (London: Sampson Low, Marston, Searle, and Rivington, 1879), 100.

${ }^{298}$ Fairlie, Sulfuric Acid Manufacture, 23.

${ }^{299}$ Ibid., 24, and Maher, "The Copper-Sulfuric Acid Industry in Tennessee," 18.

${ }^{300}$ Barclay, The Copper Basin, 1890 to 1963, 8.

${ }^{301}$ Stevens, The Copper Handbook, 1666.
} 
fertilizer, petroleum, chemicals, coal, and steel industries were the top five users in that order. $^{302}$

\section{Other Smelting Technologies}

Completing the smelting process, TCC by 1911 and DSCI by 1920, adopted Bessemer-style converters for the final refining of pyritic-smelted copper matte. Until 1920, DSCI sold all of its copper as high-grade matte, but TCC, with its new high capacity Copperhill smelter works, likely installed its first converters in $1904 .{ }^{303}$ By 1911 the company operated 4 converter stands with 15 shells that produced a $99.4 \%$ pure copper that TCC sold mainly in Europe as blister copper, although some blister copper pigs were sold to Baltimore Copper Smelting and Rolling Co, a latter incarnation of the 1860 Baltimore Copper Company, for electrolytic converting. ${ }^{304}$

Although historian Barclay and engineers Hofman and Charles Christensen recognize August Raht's contributions to the copper industry by using forced air to oxidize iron and sulfur, most credit M. Manhès work in Lyon, France, for successfully creating Bessemer blister copper from matte in $1880{ }^{305}$ Franklin Ferrel built the first U.S. Bessemer copper plant at the Parrot Smelter in Butte Montana in 1883. By 1885, the refining process involved charging a Bessemer converter with molten $40-50 \%$ copper matte and blowing air through tuyeres into the copper bath, oxidizing the last iron that, in

\footnotetext{
${ }^{302}$ Fairlie, Sulfuric Acid Manufacture, 20.

${ }^{303}$ Barclay, The Copper Basin, 1890 to 1963, 9.

${ }^{304}$ Stevens, The Copper Handbook, 1664.

${ }^{305}$ Barclay, Ducktown Back in Raht's Time, 149; Hofman, Metallurgy of Copper, 203; and Charles Christensen, "History of Converting," The Mining World 33 (1910), 1037.
} 
combination with siliceous materials in the converter lining, formed slag. Any remaining sulfur in the copper was oxidized and vented. ${ }^{306}$

The only other significant smelting developments in the Tennessee copper basin occurred in the early 1930s, when both companies began phasing out their blast furnaces. By the 1920s the copper content of the region's ores had dropped, contributing to a significant need for enhanced concentration before the materials could be smelted. In 1920, the same year it installed its first converter, DSCI built the first flotation plant in the district. Unfortunately, flotation-concentrated ore is not smeltable in a blast furnace, and the company sold this copper simply as high-grade concentrate. In 1925, DSCI reorganized as the Ducktown Chemical and Iron Company (DCI), and after adding a second flotation plant in 1927, it built an iron sinter plant, which permitted the recovery of significant quantities of iron from its ores. For the first time in thirty-six years of calling itself an "iron" company, DCI actually sold iron. ${ }^{307}$ In 1931, DCI officially ended blast furnace operations, and all recovered copper was sold as concentrate while the acid plant produced acid from the sulfur-rich sinter plant gases. ${ }^{308}$ By 1936 , the company's raw materials were dwindling, and it could not compete economically with its much larger neighbor and sold out, leaving TCC the sole producer in the area.

In the 1920s TCC also began a program to eliminate its blast furnaces. Called the "all-milling" plan, the company built a flotation plant and a four-roaster iron sinter plant

\footnotetext{
${ }^{306}$ Christensen, "History of Converting," 1036-1037.

${ }^{307}$ Maher, "The Copper-Sulfuric Acid Industry in Tennessee," 17. Iron sinter is created by first roasting flotation-concentrated iron-rich pyritic ores to release sulfur gas and create calcine (roasted ore concentrate). Gases are transferred to the acid plant, and the calcine is sintered on a traveling grate in a high-heat process that drives off any remaining sulfur and changes the structural characteristic of the material, which assays $70 \%$ iron and was sold to the steel industry.

${ }^{308}$ Barclay, The Copper Basin, 1890 to 1963, 9-11.
} 
in 1923. By the mid-30s TCC had completed its transition, which included the incorporation of the already "all-milling" DCI. With a second acid plant built at the start WWI, new iron sinter plants constructed in the early 1930s, and a U.S. Government-built acid plant on its property in WWII, TCC had successfully diversified. It now sold copper, different grades of acid, iron sinter, copper sulfates, fungicides, insecticides, zinc concentrates, organic chemicals, sodium hydroxide, ferric sulfate, and granulated slag. ${ }^{309}$ Despite the apparent success of the "all-milling" program, TCC built a reverberatory furnace at its smelter in 1940 and returned to smelting and refining copper. ${ }^{310}$

\section{Montana-Richest Hill and Biggest Smelter on Earth}

The Michigan copper smelting industry experimented with advanced techniques but in the end, by and large, smelted its copper in basically the same way it had at the beginning because Michigan ores neither warranted nor permitted great infusions of new technology. Tennessee's high-sulfur, high-iron ores led to the early $20^{\text {th }}$-century adoption of pyritic smelting and colossal acid plants. Montana, on the other hand, advanced not only the scale of smelting, but also developed and refined existing European technologies, many of which made their way back to Tennessee or burgeoning new districts in Utah and Arizona.

Like Ducktown, gold prospectors first explored the Butte area. Unlike the Tennessee district, however, Montana prospectors discovered placer gold deposits often interlaced with copper. They established a mining camp in 1864 and built the first

\footnotetext{
${ }^{309}$ Ibid., 44.

${ }^{310}$ Maher, "The Copper-Sulfuric Acid Industry in Tennessee," 6.
} 
regional smelter in 1866. Despite constructing a second furnace in 1868, most of the gold-copper placers were worked out by $1869 .{ }^{311}$ Although a few quartz mines and mills remained open, Butte was practically abandoned until 1875 when miners discovered silver ore lodes several hundred feet below the surface. Silver proved to be a slightly longer-lasting metal in the district than gold, and 12 mines operated in $1877 .{ }^{312}$ Silver mining, however, led to significant changes in the region. The burgeoning industry required a metallurgical infrastructure, and many mines built mills and smelters, before the railroad reached the region in 1881. More important, 100 feet below the silver lodes, sat the richest copper veins in the world. ${ }^{313}$ (See Figure 4.13) Although copper was continually recovered in small quantities from the 1860 s, the district remained primarily a precious metal mining camp through the early 1880 s.

Initially all Montana copper ores were simply concentrated. The mines tried to import Cornish stamps used in Michigan, but the hard chalcocite $\left(\mathrm{Cu}_{2} \mathrm{~S}\right)$, the primarily ore, was ultimately too brittle for stamping and led to significant milling losses. ${ }^{314}$ Eventually the region settled on rollers, crushers, and water separation to process the ore and eliminate gangue, and sent concentrates and high-content ores to Swansea, Freiberg (Germany), and Baltimore for smelting and refining. ${ }^{315}$ However, like all other copper districts, as the rich ore gave way to poorer ores, and mining companies introduced matte

\footnotetext{
${ }^{311}$ Ralph I. Smith, "History of the Early Reduction Plants of Butte, Montana," (Butte, Montana: State of Montana Bureau of Mines and Geology: Montana College of Mines, 1953), 1-2.

${ }^{312}$ Hyde, Copper for America, 81.

${ }^{313}$ Smith, "History of the Early Reduction Plants of Butte, Montana," 2-5.

${ }^{314}$ Laist, "Seventy-Five Years of Progress in Smelting and Leaching of Ores," 128.

${ }^{315}$ Smith, "History of the Early Reduction Plants of Butte, Montana," 5.
} 


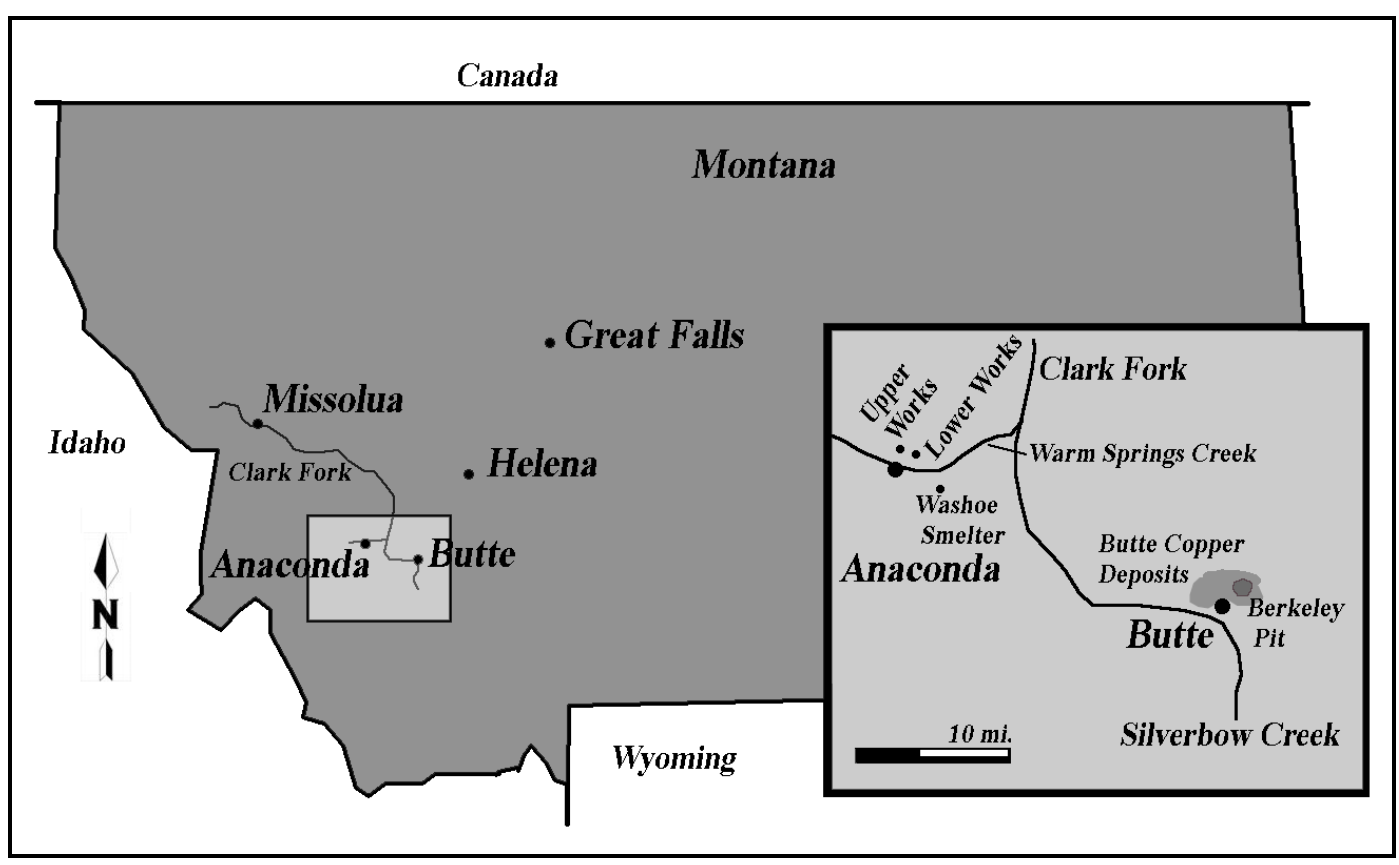

Figure 4.13 Butte-Anaconda Copper District Montana (Source: Author)

smelting and sent partially smelted copper to Baltimore, Swansea, or Black Hawk, Colorado, for finishing and refining. Most of the early 1880s smelters operated on Welsh principles with some combination of 45 " "long-hearth," hand-rabbled reverberatory roasters and 18 'reverberatory matting furnaces. ${ }^{316}$

William Clark's Colorado and Montana Smelter, in partnership with the Boston and Colorado Smelting company from Black Hawk, Colorado, opened the first dedicated copper smelter in Butte in 1879. Following the opening of the next smelter, the Montana Copper Company's Colusa Smelter in 1880, came the Parrot Smelter in 1881. Sometime after 1881, the founder of the original Colusa smelter opened the Bell Smelter, featuring

\footnotetext{
${ }^{316}$ Ibid., 8, and Laist, "Seventy-Five Years of Progress in Smelting and Leaching of Ores,” 129.
} 
the first successful blast furnaces in the district for copper matte smelting. ${ }^{317}$ In 1884 , William Clark built a second smelter, this one called Clark's Colusa Smelter to distinguish it from the Montana Company's. ${ }^{318}$

In 1887 a Boston capitalist formed the Boston and Montana Copper and Silver Mining Company and bought several properties from William Clark including "Clarks Colusa" mine and its smelter which was renamed the "Lower Works" by the company. In 1888 Boston and Montana purchased Montana Copper Company’s Colusa smelter, and renamed it the "Upper Works," and ran both sites until it opened the Great Falls Reduction Works, 150 miles north of Butte in 1893 and closed its local smelters. A second Boston group formed the Boston and Butte Mining Company in 1888 to develop several mines and opened a smelter that same year. In 1890, the Boston and Butte smelter successfully expanded its reverberatory matting furnaces to 50' long. In 1887 William Clark bought the 1883 Butte Reduction Works that he operated until 1910, when it, like the Colorado and Montana, Parrot, and 1892 Montana Ore Purchasing Co., were purchased by the expanding Anaconda Copper Company and closed. 319

In 1881, the second year Marcus Daly ran the Anaconda Mine in Butte, he returned a short-lived profit from silver mining. In 1882, just as the Anaconda's silver lode ran out, a narrow, but promising, copper vein appeared. ${ }^{320}$ By 1883 , Daly was working one of the richest copper sulfide veins in the world, measuring between 50 and

\footnotetext{
${ }^{317}$ Smith, "History of the Early Reduction Plants of Butte, Montana," 6-8.

${ }^{318}$ Hyde, Copper for America, 85.

${ }^{319}$ Ibid., 85-86, Brian Shovers et al., Butte \& Anaconda Revisited: An Overview of Early-Day Mining and Smelting in Montana, Special Publication 99 (Butte, Montana: Montana Bureau of Mines and Geology; Montana College of Mineral Science and Technology, 1991), 40, and Smith, "History of the Early Reduction Plants of Butte, Montana," 6-8.

${ }^{320}$ Smith, "History of the Early Reduction Plants of Butte, Montana," 7.
} 
100 feet wide and assaying between 12 and 50\%. In addition to encouraging significant improvements and expansions in the mine, Daly convinced his investors to build a smelter, not in Butte, where he believed land was too expensive and water too difficult to come by, but at a site on Warm Spring Creek, 26 miles west, that would eventually be named after the company. ${ }^{321}$

The first Anaconda smelter, opened in 1884, included the world's largest concentrating mill, thirty-four hand-rabbled long-hearth reverberatory roasters, twentysix matting furnaces, two seventy-ton blast furnaces, and two large 115- and 175-foot tall smoke stacks, with a total site capacity of 450 tons of processed ore per day, with all matte initially shipped to England for refining. ${ }^{322}$ By 1886, the capacity of the smelter complex had increased to 1000 tons of ore per day, and Daly replaced the labor intensive hand-rabbled reverberatory furnaces with forty new Bruckner Roasters. In 1887, due to technological and space limitations of the works, Daly built a second smelter, designated the "Lower Works" and renamed the original site the "Upper Works" just like the Boston and Montana smelters is Butte.

Although the Lower Works burned in 1889, Daly rebuilt it, increased its capacity to 3000 tons of ore per day, and added ninety-six Bruckner roasters, twenty-eight matting furnaces, four Wethey roasters, eight McDougall roasters, six 8' blast furnaces, and three tall stacks to vent the works. In a move to further retain all capital from copper production and complete refining in Anaconda, he installed a fifteen-stall upright

\footnotetext{
${ }^{321}$ Hyde, Copper for America, 84.

${ }^{322}$ Shovers et al., Butte \& Anaconda Revisited, 31; Laist, "Seventy-Five Years of Progress in Smelting and Leaching of Ores," 129; and Hyde, Copper for America, 84.
} 
Bessemer converter plant at the Upper Works, built the nation's third electrolytic refining plant between the two works, and added a converter plant to the Lower Works. ${ }^{323}$ The combined capacity of both works reached 4000 tons of ore per day. ${ }^{324}$ (See Figure 4.14) With the new converters and refiners, copper shipped from Anaconda left at $99.97 \%$ pure and finally challenged the purity of Michigan Lake copper.

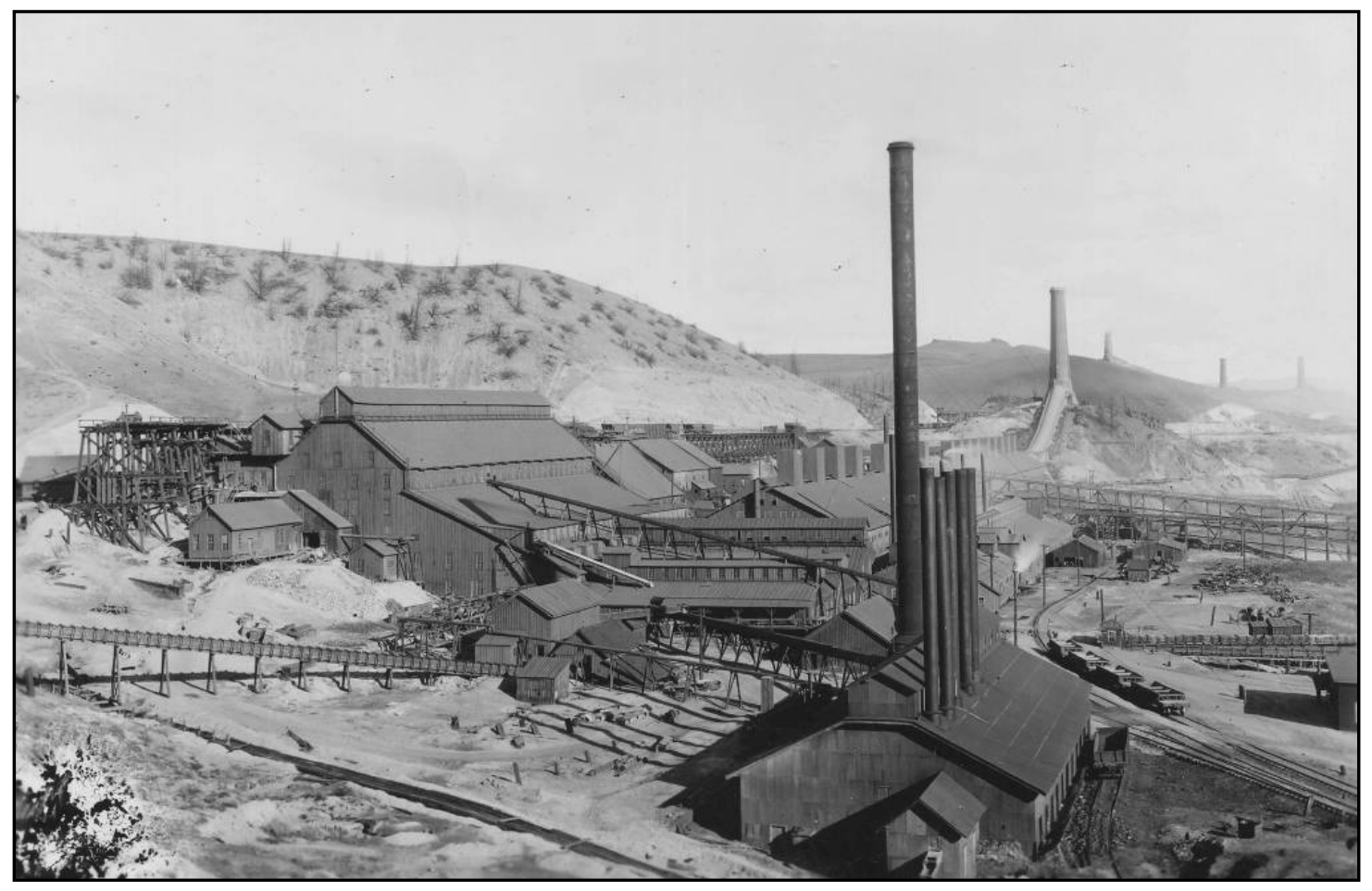

Figure 4.14 Anaconda Upper Works Smelter with Lower Works stacks in the background and electrolytic plant in the middle ground off to the right ca. 1895. (With permission of Butte-Silver Bow Archives.)

\footnotetext{
${ }^{323}$ Laist, "Seventy-Five Years of Progress in Smelting and Leaching of Ores," 129 and Shovers et al., Butte \& Anaconda Revisited, 31.

${ }^{324}$ Fred Quivik, "The Anaconda Company Smelters: Great Falls and Anaconda," The Speculator 1, no. 2 (1984), 40.
} 
Although electrolysis was discussed above in conjunction with Calumet and Hecla's Buffalo Smelter, and Bessemer converting with the Tennessee Copper Company plant, both processes were refined in Montana before they were installed in Michigan or Tennessee. As noted above, the first U.S. electrolysis plant was in Baltimore and the fourth in Buffalo, but the first plant directly associated with a copper mine was developed by Michigander Frank Klepetko of the Boston and Montana smelting company at Great Falls in 1893. Similar to the Buffalo site, Great Falls with its new hydroelectric plants offered great potential for inexpensive electricity and, with increasing consternation over smelter smoke in Butte, the Boston and Montana Company built a large smelter and refinery at the falls and closed its Upper and Lower Butte works. ${ }^{325}$

The new 1893 Great Falls smelter included twenty-four Bruckner roasters, eight reverberatory matte furnaces, and two five-ton upright converters. By 1902 the site included eighteen 6-hearth McDougall-Evans-Klepetko roasters, five gas-fueled matting furnaces, five blast-furnaces, twelve upright converters, one anode-casting reverberatory furnace with a Walker Caster, a 312-tank electrolytic plant, and four reverberatory refining furnaces and was second in production only to Anaconda, which by 1915 would purchase the Boston and Montana Company and the Great Falls refinery. ${ }^{326}$

According to Jonathan Leitner, the ability to home-refine Montana's copper matte, previously sent primarily to United Kingdom, proved the decisive blow to the

\footnotetext{
${ }^{325}$ Hyde, Copper for America, 86.

${ }^{326}$ Smith, "History of the Early Reduction Plants of Butte, Montana," 12.
} 
already declining British copper industry. ${ }^{327}$ Sharp declines in British production occurred in the 1890s as both Great Falls and Anaconda smelters added electrolysis, and again in the 1910s when Anaconda's capacity was greatly increased. ${ }^{328}$ (See Figure 4.1)

\section{Technological Advances in Montana}

At the Parrot smelter, in 1884, Andrew Davis built the first Bessemer converter plant for copper in the United States. It included three "egg-shaped" upright converters and a small cupola for remelting intermediate mattes. Despite two very different general arrangements, upright and horizontal, all converters operated essentially the same, and, according to Laist, outside of modest improvements in charging and capacity, few significant technological changes occurred with them through the 1950s, with the exception of improved lining materials that decreased the frequency of lining changes from every 6 or 7 charges to once every few years. ${ }^{329}$ (See Figure 4.15 below)

Following system improvements in refining, Montana smelters turned to improving roasting. Like pyritic smelting, roasting improvements were executed largely to improve production flow and eliminate labor rather than to curb or control smoke emissions. The first attempts at roasting mechanization were largely efforts to rabble ore in modified reverberatory furnaces. The first radical design change came with the

\footnotetext{
${ }^{327}$ Jonathan Leitner, "Red Metal in the Age of Capital: The Political Ecology of Copper in the NineteenthCentury World-Economy," Review-Fernand Braudel Center for the Study of Economies, Historical Systems, and Civilizations 24, no. 3 (2001), 421.

${ }^{328}$ Although Anaconda and Great Falls were certainly the largest copper refineries, between 1883 and 1902, 10 new refineries opened in the United States, increasing domestic annual capacity from 38,000 tons or twenty percent of US output in 1893 to 347,000 tons, equal to seventy-five percent of US output in 1906. (See Hyde, Copper for America, 92)

${ }^{329}$ Laist, "Seventy-Five Years of Progress in Smelting and Leaching of Ores," 136-137.
} 
Pearce-Turret, whose 36'-diameter circular hearth had mechanical rabbles that rotated around a central shaft. The device had up to six circular stacked shelves to increase production, but its poor operating performance limited its wide-spread use. ${ }^{330}$ The much simpler Bruckner Cylinder, a large, horizontal cylindrical tub that rotated on rollers and tumbled ores over each other like a household dryer, saw much greater use, but its separate firebox used considerable amounts of fuel.

The most successful of the new roasters, however, adopted the rotating circular shelf concept of the Pearce-Turret. The new devices were first developed by McDougall in Liverpool, England, in 1870, and featured several stacked, cylindrical, shelves, most not larger than 10-15 feet in diameter. In the U.S. successful adaptations included the Wedge, Herreshoff, and the Evans-Klepetko developed at Great Falls. The McDougallEvans-Klepetko married multiple-shelf circular hearths with a pyritic process in an enclosed and insulated circular tower. It used the heat of sulfur and iron oxidation to roast the ores on separate, non-rotating, enclosed shelves, with each shelf essentially becoming a separate hearth. Mechanical rabbles rotated by a central shaft directed ores to chutes that dropped them onto the next lower shelf. Without a separate fire box, the roasters took up considerably less floor space, required fewer workers to tend, and consumed virtually no fuel. $^{331}$ (See Figure 4.15)

\footnotetext{
${ }^{330}$ Ibid., 133.

${ }^{331}$ Hofman, Metallurgy of Copper, 80 and 87, Laist, "Seventy-Five Years of Progress in Smelting and Leaching of Ores," 133.
} 


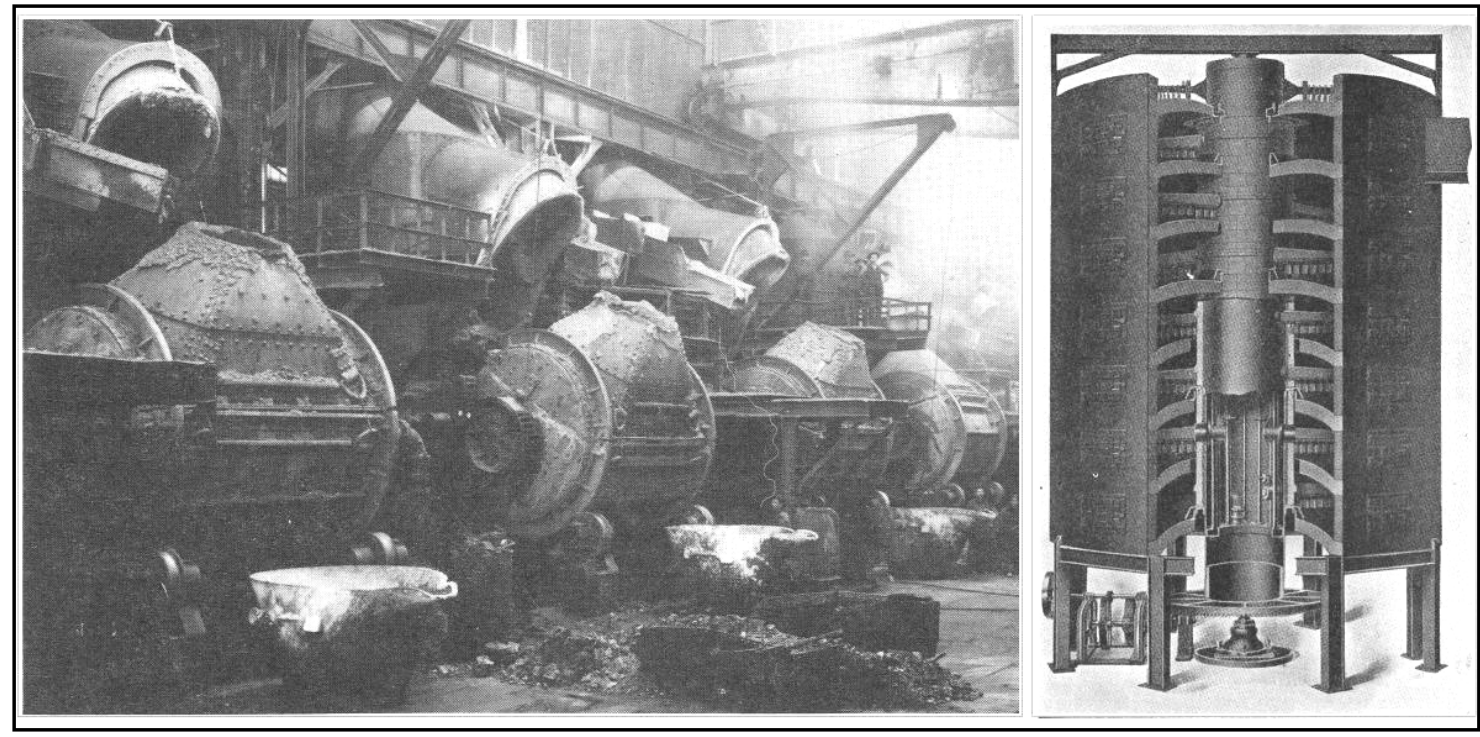

Figure 4.15 Upright 12'-wide Bessemer Converters of the Washoe Smelter for refining smelted copper matte from the reverberatory furnace (left) and a typical McDougall-style Wedge Roaster 33' high used to burn sulfur out of sulfide copper ores using the heat of sulfur oxidation to propel the process (right).

(Adapted from Shovers 39 and Hofman 95)

Montana smelters also made advances in roasting in the late $19^{\text {th }}$ century. Not only were the hand-rabbled, hand-charged long-hearth reverberatory roasters labor intensive, but the smoke from so many smelting sites, some of whom still heap-roasted large pieces or even stall-roasted ore-concentrates, taxed the residents of the growing town of Butte. As early as 1885 citizens complained about the smoke destroying wild flowers and strawberries, but to no avail. Attempts to control the smoke or dissipate it with tall stacks largely failed, especially as output and heap roasting continued to increase through the 1880 s as Montana surpassed Michigan's copper production. In 1891, the city passed an anti-smoke ordinance that ended all heap roasting and required all smelters to erect a minimum $75^{\prime}$-tall stack. ${ }^{332}$

\footnotetext{
${ }^{332}$ Smith, "History of the Early Reduction Plants of Butte, Montana," 11-12.
} 


\section{The Dominance of Anaconda}

By 1899, Marcus Daly's acquisition of other high-output Butte mines and the limitations of the existing Upper and Lower smelting works in Anaconda, drove the need for smelter expansion. ${ }^{333}$ Daly authorized \$20 million and hired Frank Klepetko from Great Falls to design and build the new facility that would become the Washoe smelter. ${ }^{334}$ Daly, who directed Klepetko to design a single new complex using the latest equipment to maximize efficiencies and provide for future expansion in each department, died before construction began in 1900. Klepetko selected a 230-acre site on an Anaconda hillside from 200 to 700 feet above the valley floor to take advantage of gravity, similar to what he would do at the Michigan Smelter a couple of years later. The new, complete plant had concentrating, roasting, blast furnace and reverberatory smelting, converting, and electrolytic refining departments all linked by internal transportation with an original throughput of 5000 tons of ore daily. It was the largest smelting plant ever built and in 1902, consumed 750 tons of coal, 2500 tons of lime flux, $778,000 \mathrm{kw}$ of electricity, and 60 million gallons of water each day. By 1908, the smelter processed 12,000 tons of ore and produced 600,000 pounds of copper and 9000 tons of slag and tailings per day, doing so at $39 \%$ less cost than the older works. ${ }^{335}$ With the completion of the Washoe smelter, the Upper and Lower works became known simply as the Old Works and were torn down.

\footnotetext{
${ }^{333}$ Shovers et al., Butte \& Anaconda Revisited, 21, and Hyde, Copper for America, 102.

${ }^{334}$ Shovers et al., Butte \& Anaconda Revisited, 35, and Hyde, Copper for America, 102.

335 Shovers et al., Butte \& Anaconda Revisited, 35, and Hyde, Copper for America, 102.
} 
According to Laist, few $19^{\text {th }}$ century technological changes in smelting rivaled Anaconda's effort to radically increase the size of its furnaces. In 1904, Anaconda Copper Mining Company (ACM) took two of its 1901, 50'-long reverberatory furnaces and joined them back to back with a single fire-box at one end and single flue at the other creating in effect the largest reverberatory furnace ever built. With such a large size, the Washoe smelters discovered they could continuously charge the furnace at the fire-box end and that the latent heat of the furnace "greatly accelerated fusion" and effected a $50 \%$ reduction in fuel needs per ton of copper smelted, all with little increase in personnel needs. The new furnaces, now producing 250 tons of copper per day, became the standard in the industry and were copied in Utah, Arizona, Nevada, and Mexico. ${ }^{336}$

Echoing the changes in reverberatory smelting at the turn of the century, blast furnaces, which did not undergo radical operational changes, simply got bigger as well. While the distance between blast furnace tuyeres never got much wider than 57 " to ensure adequate air pressure, the average furnace length grew to 8 ' from a 36 " cylinder. The biggest blast furnace at Anaconda appeared in 1906, was 87' long, and smelted 2500 tons per day. ${ }^{337}$

\section{Montana Smelting}

By 1910, Anaconda's gigantic smelter operated sixty-four Evans-Klepetko roasters, eight reverberatory furnaces over 100' long, three Mathewson 87' blast furnaces, one briquetting plant, and eight 12 ' horizontal converters. Its concentrated ores

\footnotetext{
${ }^{336}$ Laist, "Seventy-Five Years of Progress in Smelting and Leaching of Ores," 150

${ }^{337}$ Ibid., 135.
} 
were smelted in the large reverberatory furnaces for $45 \%$ copper matte. The matte was sent to the converter department and refined to $99 \%$ pure blister copper, remelted in a smaller reverberatory and cast into anodes that were taken to the electrolysis department and purified to $99.97 \%$. The blast furnaces were charged with coarse ores, concentrate, reverberatory and converter slag, and $10-1 \mathrm{~b}$ briquettes. $^{338}$ The entire smelter process generated between 3000-4500 tons of slag daily that was blasted with water to granulate it, then sluiced to dewatering ponds, and transported to a single colossal waste pile the company used from 1902-1976. ${ }^{339}$ (See Figure 4.16, 4.17, and 4.18)

\section{Environmental Problems and Responses}

In addition to concentrator slag and tailings, the site generated considerable smoke. From nearly the start of smelting at the Washoe, regional farmers complained about the smoke problem and damage to crops and livestock. In response to by local agriculturists, the works replaced four small(er) stacks with a single 300' stack on a plateau 700 feet above the valley floor in 1903. The stack connected to the rest of the site by a $2300^{\prime}$ flue system designed to cool the smoke, catch dust, and recover arsenics before they exhausted the top. The stack complex included a roasting furnace and small reverberatory furnace to process arsenical dust and a series of long-narrow rooms, called kitchens, to encourage further arsenic condensation and recovery. ${ }^{340}$

\footnotetext{
338 Copper: From Mine to Finished Product, 21, and Shovers et al., Butte \& Anaconda Revisited, 39-40. ${ }^{339}$ Shovers et al., Butte \& Anaconda Revisited, 41.

${ }^{340}$ Ibid., 41, and Quivik, "The Anaconda Company Smelters: Great Falls and Anaconda," 42.
} 


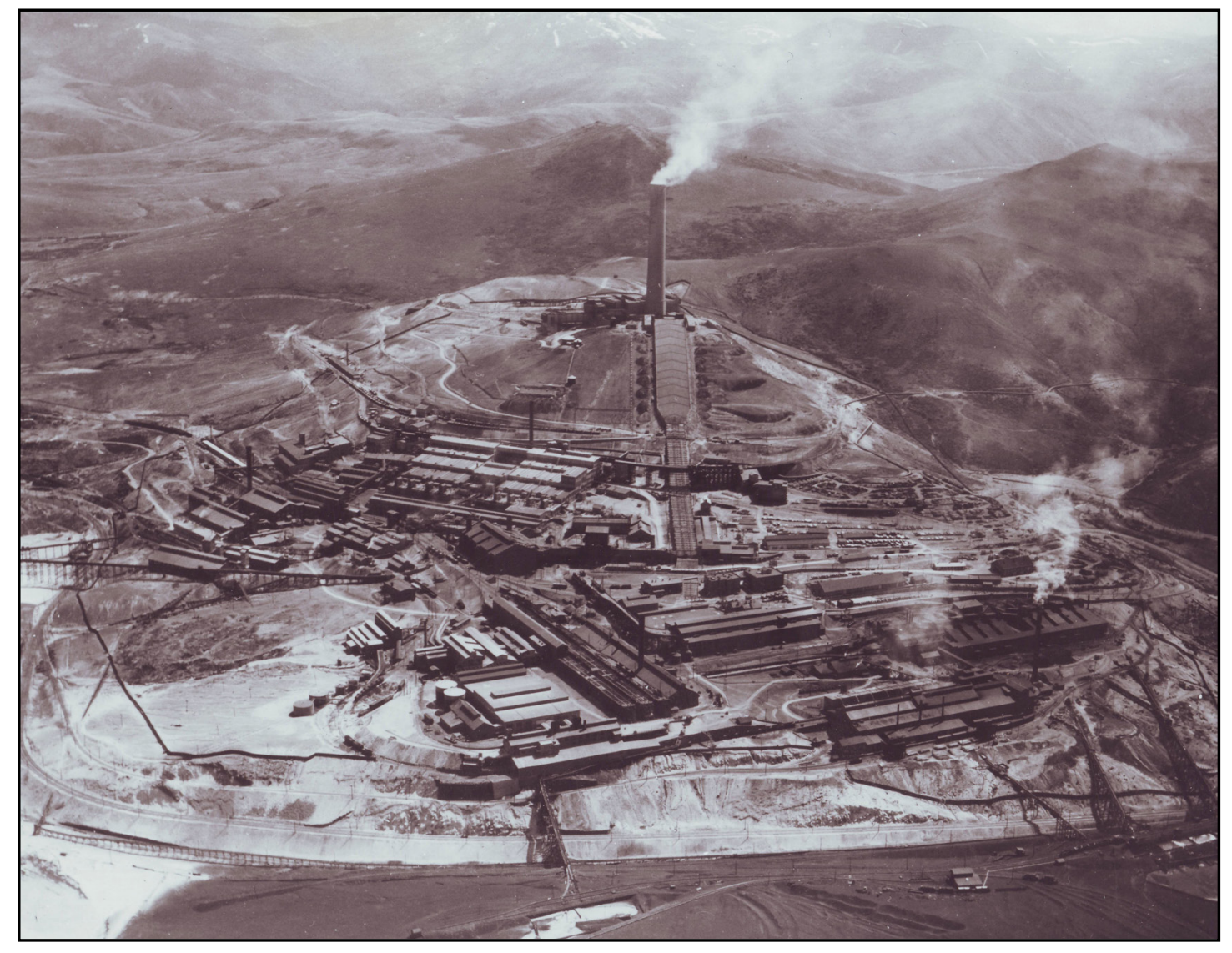

Figure 4.16 Anaconda Washoe Smelter ca. 1950s with separate concentrating, roasting, reverberatory furnace, zinc, leaching, and blast furnace buildings on the hill side and arsenic recovery, dust collection, and smoke stack on the hill top linked by a flue. (With permission of Marcus Daly Historical Society) 


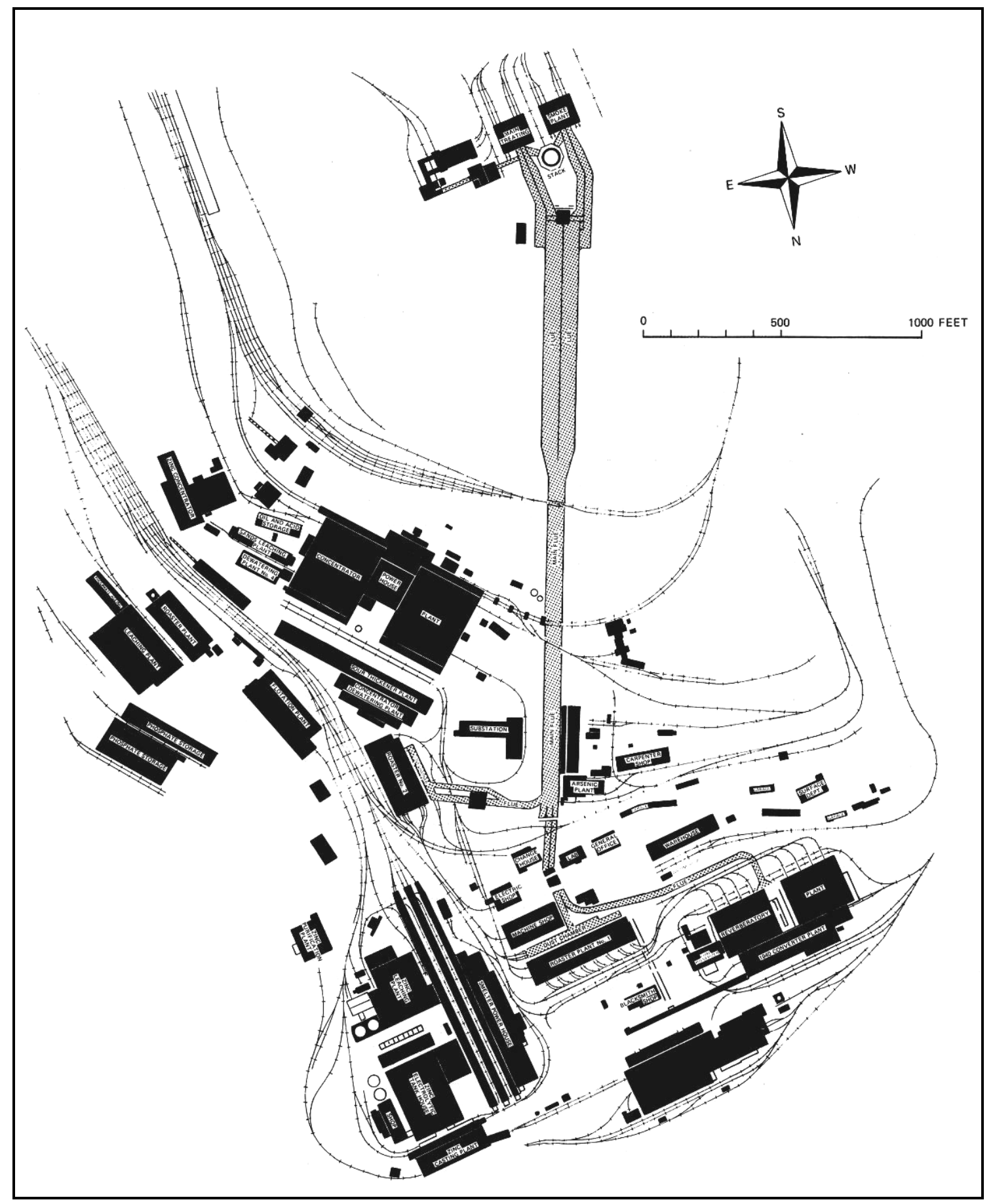

Figure 4.17 Diagram of Washoe Smelter, ca. 1950. (After, Shovers et al. 1991, 36) 


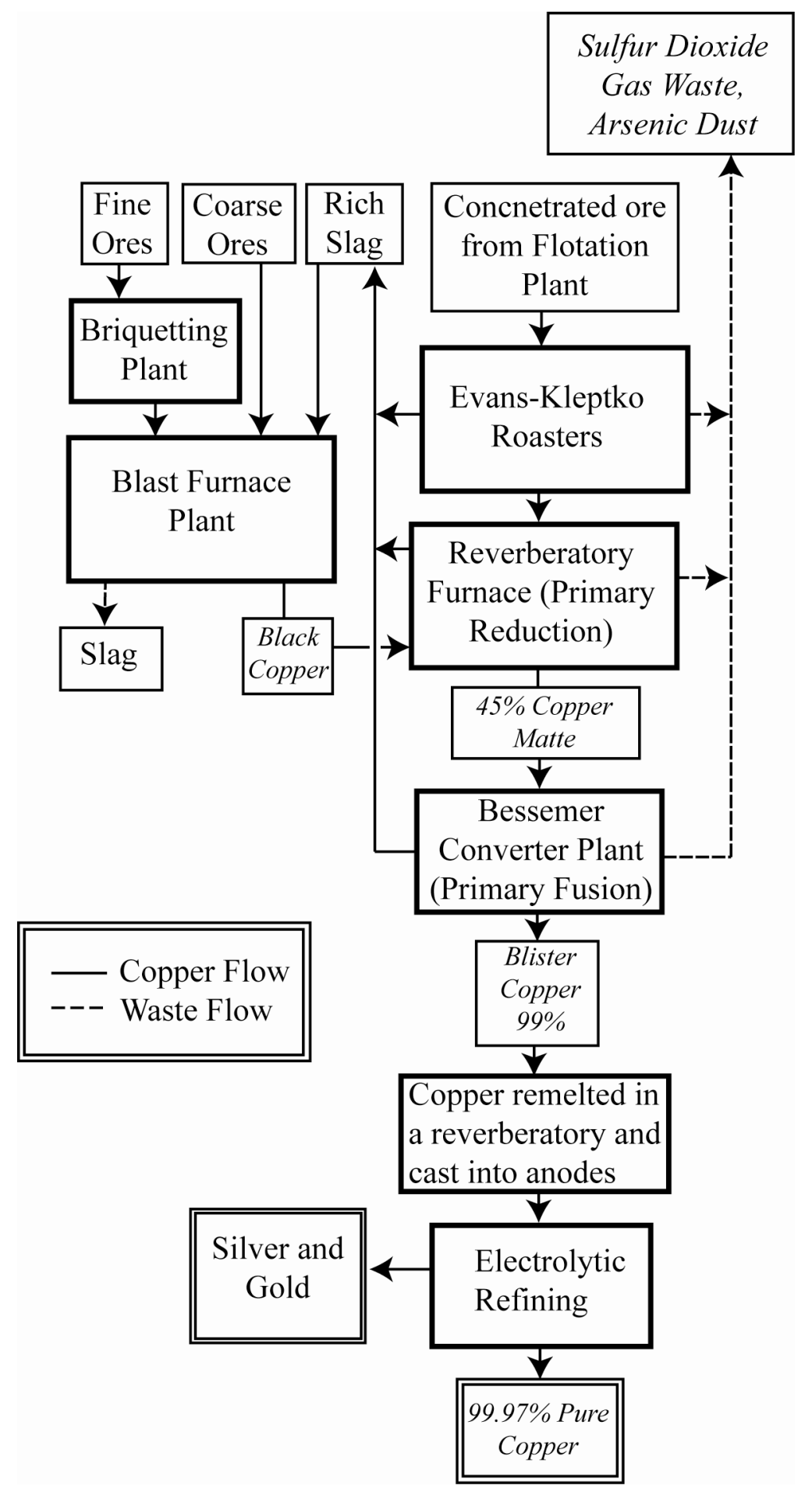

Figure 4.18 Montana Smelting Practices, ca. 1905 (Source: Author) 
Undaunted, in 1905 farmers brought a second suit against the Washoe and Anaconda claiming damage to crops and livestock. Despite admitting to "some damages" and agreeing to pay, Anaconda claimed the farmers grossly over-estimated financial losses. In his ruling, Federal District Judge Oliver T. Crane agreed with the Tennessee state judge in the Madison case, maintaining that the benefits from smelting outweighed the damages to farmers, who relied on mining and smelter workers to purchase their goods. He awarded the farmers a meager $\$ 350$ in damages. $^{341}$ In 1909 , however, at the behest of Teddy Roosevelt, the United States attorney general sued Anaconda for damages to Federal lands modeled after the successful Georgia v. Ducktown case, and proposed a similar acid plant solution. ${ }^{342}$ Unfortunately, an economic demand for sulfuric acid and fertilizer did not exist at the time in the West, and Anaconda agreed to independent monitoring and equipment upgrades such as new Cottrell precipitators. ${ }^{343}$ Despite poor potential for fertilizer sales, the company added a 100-ton chamber sulfuric acid plant in 1914 to recover sulfur from the smoke, expanding it to 98,000 square feet in 1919 producing 215 tons per day. ${ }^{344}$

In 1914, Anaconda bought the International Smelting and Refining Company, expanding its operations into Arizona, Utah, Indiana, New Jersey, and Mexico. In 1915, Anaconda, which had been keeping its many separate mines and holdings under the

\footnotetext{
${ }^{341}$ Katherine Aiken, "Western Smelters and the Problem of Smelter Smoke," in Northwest Lands, Northwest Peoples : Readings in Environmental History, ed. Dale Goble and Paul W. Hirt (Seattle: University of Washington Press, 1999), 505-506.

${ }^{342}$ Fred Quivik, "Smoke and Tailings: An Environmental History of Copper Smelting Technologies in Montana 1880-1930" (PhD, University of Pennsylvania, History and Sociology of Science, 1998), 399. ${ }^{343}$ Ibid., 350.

${ }^{344}$ Shovers et al., Butte \& Anaconda Revisited., 41.
} 
Amalgamated Copper Company, reorganized as a single company, the Anaconda Mining Company (ACM), in an effort to economize management and better fight lawsuits. In 1917, the smelting works expanded to process all the copper produced from new mines and included one-hundred roasters, eleven blast furnaces, eight reverberatory furnaces, and seven converters. The increased capacity, however, overwhelmed the existing dust collection system by an estimated 50\%. Responding to new lawsuit threats and the need for increased handling capacity, ACM constructed, not just the largest smoke stack ever, but the tallest masonry structure ever built. The new stack measured 585' tall, sixty feet across the top and 75 feet across the bottom. (See Figure 4.14) It featured a new Cottrell electrostatic plant that used high voltage electricity to more effectively precipitate and capture $90 \%$ of the arsenic from the flue gases. ${ }^{345}$

\section{$20^{\text {th }}$ Century Evolution of Anaconda}

Other improvements and processes at the Washoe works included a plant that manufactured zinc from Butte ores from 1915 to 1972. ACM also operated a brick plant from 1922 to 1980, a fertilizer plant that used acid from the chamber plant to create fertilizer with phosphate rock from 1923 to 1961, and a ferro-manganese plant from 1941 until the 1950s. In 1923, it built a flotation plant to concentrate the poorer ores and, like smelters in Tennessee and Michigan, started phasing out its blast furnaces. In 1933 it

\footnotetext{
${ }^{345}$ Ibid., 41.
} 
installed waste-heat boilers on its reverberatory furnaces and converted the steam to electricity, producing up to $30 \%$ of the site's mechanical power. ${ }^{346}$

Also in 1923, in a move to expand operations, diversify, and more fully vertically integrate as its Butte mine values and ore reserves start to decline, Anaconda purchased the Chuquicamata mine in Chile, one of the richest porphyry deposits on earth, and soon after bought the El Teniente and Potrerillos mines too. ${ }^{347}$ Anaconda would ultimately purchase brass rolling mills, copper foundries, uranium mines, aluminum, lead, and zinc works, and a host of other end-product manufactories in an attempt to be completely integrated and the largest non-ferrous company on the planet. $^{348}$

Following a failed attempt at underground block caving in the early 1950s, Anaconda turned to open-pit mining in Butte and opened the Berkeley Pit in 1950. This was a deep new surface mine created to excavate the large low-grade copper deposit that sat below portions of the city of Butte and other district cities. The pit not only forced the relocation of several neighborhoods and the destruction of popular parks, entertainment venues, and more than a dozen underground mines, but it also destroyed the late $19^{\text {th }}$ century smelting district that once housed the Butte and Boston smelter, Montana Ore Purchasing Company smelter, and Boston and Montana upper and lower works. ${ }^{349}$ Although the public outcry about the loss of town sites in the 1950 s was muted by the promise of jobs and extending the life of the declining district, by the 1970s, talk of pit expansion and the removal of Butte's central business district prompted the first elements

\footnotetext{
346 Ibid., 42-44.

${ }^{347}$ Hyde, Copper for America, 172.

${ }^{348}$ See Marcosson, Copper Heritage; the Story of Revere Copper and Brass Incorporated.

${ }^{349}$ Shovers et al., Butte \& Anaconda Revisited, 13.
} 
of an organized protest movement, one that would play a major role in redefining the city over the next thirty years, especially as the pit became the national archetype of miningrelated environmental disasters. In 1976, the Atlantic Richfield Oil Company (ARCO) bought Anaconda after losses stemming from the 1973 expropriation of ACM's Chilean operations devalued the mining company. Anaconda had replaced its reverberatory with electric furnaces to cut emissions in the 1970s, but in 1980 closed its smelter for good. ${ }^{350}$ Important advances made in mining and milling techniques in the late $19^{\text {th }}$ and early $20^{\text {th }}$ centuries, including open pit excavation and the extensive use of flotation, opened significant porphyry deposits in Utah and Arizona and new smelters were built at or near the mines. New copper lodes were also opened in Alaska, Nevada, and New Mexico and stand stand-alone smelters operated in Tacoma, Washington, and El Paso, Texas, to process much of the new ores. Despite accelerated production and consumption, few major technological changes occurred in copper smelting following the general demise of the blast furnace in the 1920s, until the wider use of electric furnaces in the 1970s and flash smelting in the 1980s. ${ }^{351}$

American copper smelting evolved from relatively small-scale European technologies into some of the largest metallurgical applications on the planet. Although European smelters developed technologies to smelt and refine copper over many centuries, their greatest technological advances came late, at a time of declining European

\footnotetext{
${ }^{350}$ Ibid., 41.

${ }^{351}$ Electric furnaces passed a current through the molten bath of a continuously fed charge. The natural resistance of the material generated enough heat to maintain high furnace temperatures and continually remelt new charges. Flash smelting blows dried concentrate and oxygen into a hot-furnace hearth and, like pyritic smelting, uses the heat of sulfur and iron oxidation to melt the charge. See A. K. Biswas and W. G. Davenport, Extractive Metallurgy of Copper (New York: Pergamon Press, 1980), 156.
} 
mine production. The United States, however, with rapidly expanding electrical applications that ushered in the modern world, created a demand for copper never before seen. To meet the demand, miners and smelters adapted old and new European technologies to produce copper faster and cheaper, and make available the extensive deposits of very low-grade ore that, prior to the end of the $19^{\text {th }}$ century, the world had had little use for. While none of the three sites discussed in this work mined very low grade ores, they each adopted, and in some cases advanced or even perfected, technologies that allowed them to reap first the richest ore deposits, then, with ever advancing technologies, some of the leanest deposits in their regions.

While many histories of the copper companies and copper producing regions explore the technological and economic developments of their productive years, few, until the 1990s, fully considered the after effects of this production and the waste streams generated from ores with $2 \%$ or less copper. Part II of this dissertation will examine what happens in copper-producing regions after copper companies ceased, or very substantially reduced, mining and smelting operations. One of the legacies was typically a degraded environment, the product of a century or more of producing mine tailings, slag, acid rain, and deforestation. In some copper mining and smelting districts, the degradation was severe enough to get portions listed as "Superfund" sites and involved in federal environmental remediation efforts. Another legacy was, ironically, a growing interest in preserving elements of the same industrial heritage that had caused the environmental degradation and using it to promote heritage tourism as a replacement for the now-lost industrial payrolls. 


\section{PART II}

An examination of the historic and contaminated copper mining and smelting districts in Montana, Tennessee, and Michigan, and the efforts to both clean and preserve the significant heritage landscape. 


\section{CHAPTER 5. DUCKTOWN}

Observations were made on the condition of the vegetation in the region surrounding Ducktown and Copperhill, Tennessee in the neighborhood of the copper smelters during the month of September, 1913... The area affected by the acute form of injury is probably larger than it was in 1905 and $1906 \ldots$ In the worst affected area little herbage is found, and the hills look like a desert with a greatly eroded appearance... Repeated acute injury of this sort kills the twigs of trees and finally brings about the death of whole trees.

-George Grant Hedgcock, 1914 (“Injury by Smelter Smoke,” 70-71)

...the landscape opens up, and suddenly there is a vast, raw plain, cooking in the summer sun. No trees, no plants, no signs of life, just a great expanse of dry redclay hills cut deep with massive gullies...so strange, so sudden, so out of place.

-Wilton Barnhardt 1987 ("The Death of Ducktown," 36)

"It's sort of sad. I've grown up with the painted cliffs and red hills and, in a curious way, they're quite lovely and unique....It's our history and we're proud of it... They ought to leave it to show what man can do to nature [and] what man can undo."

-Loraine Lee, 1987 (Quoted in “The Death of Ducktown,” 41)

April 11, 2008

The final drive into Ducktown, Tennessee, from Chattanooga is rather unremarkable especially given the striking, thirty-mile climb that follows the Ocoee river gorge up from Cleveland (Tenn.). One would hardly know that this stretch of river was once classified as ecologically dead and not expected to fully recover for decades. Dead, however, is a relative term. The fall of the river over 30 miles powers three Tennessee Valley Authority hydro-electric plants, offers recreational kayakers and rafters occasional white water, and hosted the 1996 Olympic paddling course. Fish and aquatic plants and insects, however, are sparse here. Heavy metals, arsenic, and acids washed into this watershed from over a century of copper mining and smelting operations in the Ducktown district. Some contamination resulted from the direct effluent of processing 
operations, but the majority came from serious and significant erosion caused by several decades of open sulfide ore roasting that, combined with mining-driven lumbering operations, left a completely denuded landscape of dirt hills and sediment-filled valleys.

Today the Ducktown area is a bucolic, forested hill top looking like any other small town in eastern Tennessee accessible by a four-lane highway exit ramp. Unlike Copperhill, its sister-city at the southern edge of the Copper Basin five miles south, Ducktown has a small commercial strip, a fast-food restaurant, and a hotel but no railroad station for excursion train stops. Driving east on U.S. 64, the only hint of any sort of past industrial activity are the signs bolted to chained gates that read "McPherson Mine" or "London Mill" or, one half-mile off the highway in downtown Ducktown, "Burra Burra Mine" and "Ducktown Basin Museum," the latter with its collection of historic buildings and equipment largely invisible from the road.

The imagery changes along state highway 68 south to Copperhill. The large flagtopped head frame of the Central Shaft towers above the trees shortly before the "Smelters" gristmill store and fireworks stand. Continuing south along the highway into Copperhill, however, the extensive, chaotic, partial remains of the Tennessee Copper Company smelter and acid plant loudly announce recent and not-so-recent industrial activity, while a quarter-mile beyond the plant, quaint downtown Copperhill's copperaccented street lights, heritage signs, and mineral gift-shops quietly suggest a past worth remembering.

A mere thirty-five years ago, however, the landscape of the Tennessee copper basin looked entirely different. Despite the cessation of all open-air ore roasting by 1905 , 
the area remained sharply denuded and moon-like, with very little vegetation as late 1973. Locals claimed that the 50 square mile basin was the only man-made landscape visible from space and among the myriad national articles and photographs about the district is a now-famous two-page National Geographic aerial image showing the sparsely populated built environment completely engulfed by totally barren red-sand hills. $^{352}$ While an abomination to some, many locals, but not all, who grew up with this landscape mourned its passing. Like the belching smoke of Pittsburgh's blast furnaces, the denuded landscape was a symbol of the region's prosperity and a significant component of its identity. Although attempts to preserve a small 30-acre portion of barren hillside have succumbed to successful revegetation (See Figure 5.1) and remediation efforts, preserving and celebrating the basin's remaining mining heritage remains a key development strategy for Ducktown and Copperhill. (See Figure 5.2)

\section{Shutdown}

Through mid-century, the Tennessee Copper Company (TCC) added additional plants in Copperhill to produce a variety of chemicals. In fact, its byproduct operations were so successful that by 1950 copper was relegated to the third leading product manufactured after sulfuric acid and iron sinter. ${ }^{353}$ In the 1950s TCC's chemical line

\footnotetext{
${ }^{352}$ Gordon Young and Emory Kristoff, "The Tennessee Valley Today," National Geographic 143, no. 6 (1973). 858-859. Despite extolling the resurgence of the Tennessee Valley largely through TVA efforts and a caption that described the success of revegetation, the key words to describe the image in 2008 included: desolate landscapes, destruction of woodlands, and nature vs. technology. See "A Barren Landscape Was Created after Miners Cut Down Forests for Fuel. Location: near Copperhill, Tennessee, Picture Id: 620678, www.nationalgeographicstock.com/ngsimages/explore/.

${ }^{353}$ M. -L. Quinn, "The Appalachian Mountains' Copper Basin and the Concept of Environmental Susceptibility," Environmental Management 15, no. 2 (1991), 183.
} 

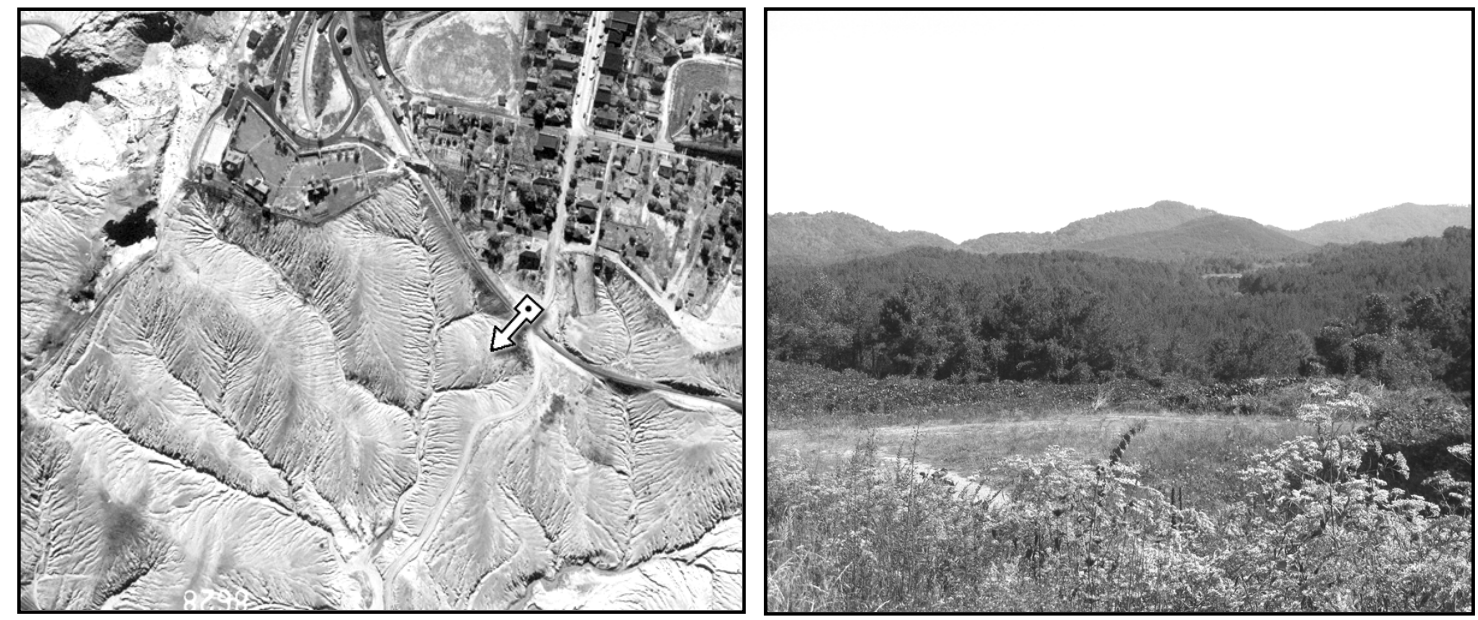

Figure 5.1 Effects of remediation. Aerial photo of Ducktown on the left was taken in 1944; the photo on the right was taken in 2008 from the point marked on the photo on the left. (Aerial photo with permission of Ducktown Basin Museum, photo on the right taken by author.)

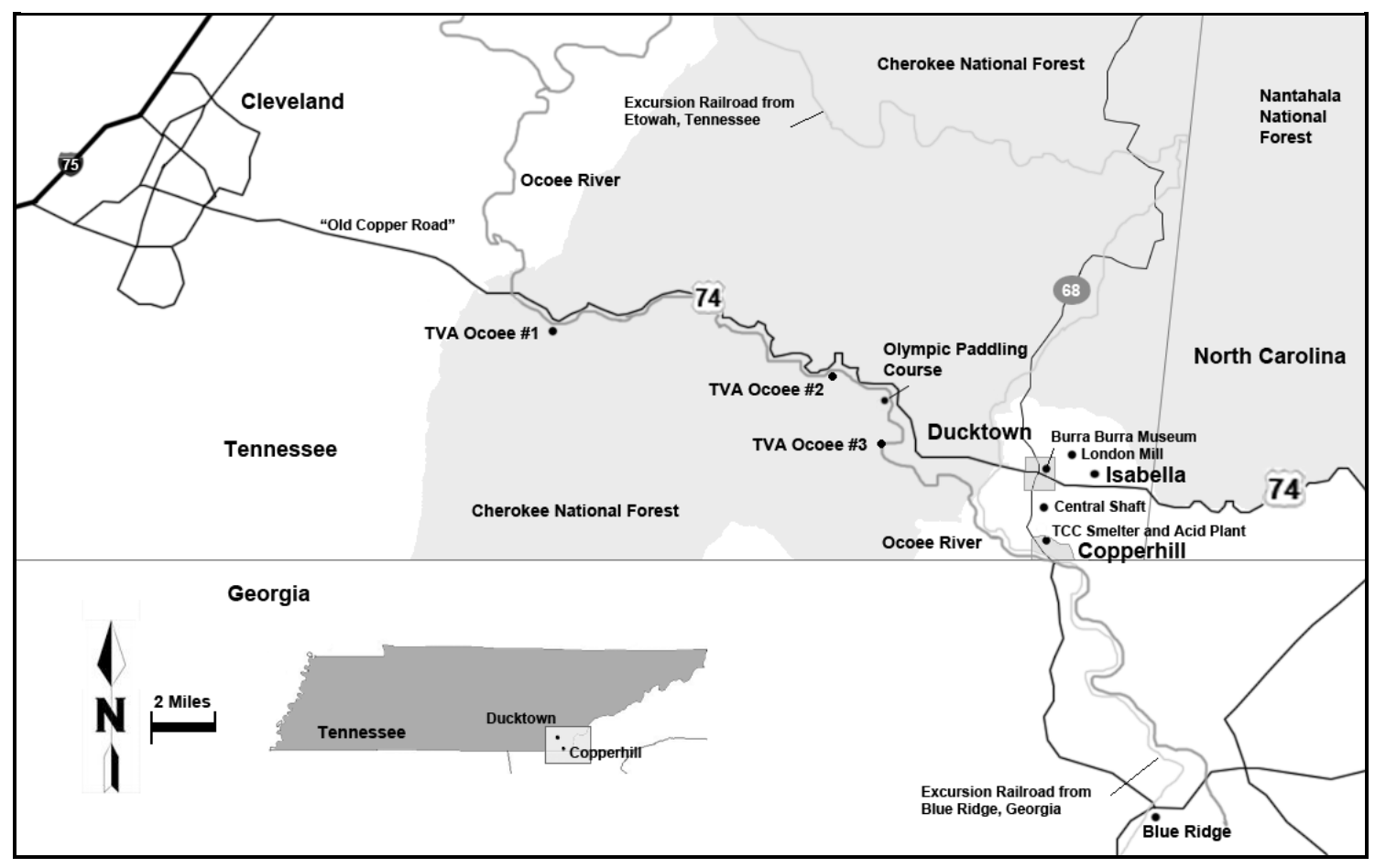

Figure 5.2 Map of Tennessee Copper Basin showing selected heritage and remediation sites. (Source: Author) 
grew even further after it added an organic sulfonating plant in 1952 and a sodium hydrosulfite plant in 1956. In 1964, the company closed its last chamber acid plant and constructed its fifth contact acid facility at Copperhill to compliment existing contact plants built in Isabella and Copperhill between 1929 and $1954 .{ }^{354}$ The former Ducktown Sulfur Copper and \& Iron (DSC\&I) dismantled and either scrapped or moved its Isabella chamber plants before being purchased by TCC in the 1930s, and TCC ultimately removed the remaining chamber and defunct contact plants in the 1970s. ${ }^{355}$

In 1963, in a move that foreshadowed later oil company takeovers of copper companies, Cities Service Corporation, the Oklahoma-based predecessor of CITGO Petroleum, bought the Tennessee Copper Company, continued underground mining and chemical production, and in 1976 began open-pit mining northwest of Copperhill. ${ }^{356}$ In 1982, the recently organized Tennessee Chemical Corporation (TChC) ${ }^{357}$ acquired the Copperhill and Isabella processing plants and remaining active mine assets from Cities Service, while Occidental Petroleum purchased the rest of Cities Services including its substantial oil refining and distribution network. In 1987 Tennessee Chemical ended copper mining in the state and in 1989 declared bankruptcy. ${ }^{358}$ In 1990, Boliden Intertrade, a Swiss corporation, purchased the Copperhill plants from bankruptcy and

\footnotetext{
${ }^{354}$ Stuart W. Maher, "The Copper-Sulfuric Acid Industry in Tennessee," ed. Division of Geology The State of Tennessee Department of Conservation, Information Circular (Nashville, Tennessee: State of Tennessee, 1966), 6-7, 18-19.

355 "Report for the Extent of Lead Contamination at the Former Isabella Lead Chamber Acid Plant, Ducktown, Tennessee," Waggoner Barge, Sumner, \& Cannon, Inc. (Nashville, Tennessee: Glenn Springs Holdings, Inc., 2003), 2.

${ }^{356}$ Maher, "The Copper-Sulfuric Acid Industry in Tennessee," 6.

${ }^{357}$ Tennessee Chemical Corporation will be referenced in the text by TChC so as not to confuse it with the Tennessee Copper Company referred to as TCC.

${ }^{358}$ Milton H. Hamilton, "North Potato Creek VOAP Order," in Site ID 70-508, Case No. 99-0480, ed. Division of Superfund (Nashville, Tennessee: State of Tennessee, Department of Environment and Conservation, 2001), 5.
} 
entered into an agreement with the U.S. EPA not to sue (or be sued for environmental damages of TCC or TChC) and continued operating the acid plant through 2000 and the organic chemical facilities through 2008. ${ }^{359}$ Properties not associated with Copperhill remained in the bankruptcy estate of the Tennessee Chemical Corporation. ${ }^{360}$

When Boliden Intertrade stopped producing acid and significantly reduced its workforce, it eliminated all but 300 of what had once been as many as 2000 jobs in the 1970s, resulting in a considerable drop in the local economic benefits from mining and chemical production. Where the 1906 Madison vs. DSCI lawsuit cited 12,000 jobs associated directly or indirectly with mining and half the county's taxes paid by DSCI and TCC, by 2001 the U.S. Government was the largest single employer in the county and controlled almost one-third of all land through the U.S. Forest Service. With inexpensive housing and open forest lands and the Ocoee River offering hiking, biking, rafting, and kayaking, tourism became the primary income-generator for the county, a fact not lost on community leaders looking to create opportunities and accessible landscapes for short-term visitors. ${ }^{361}$ Mining and agriculture, the two largest economic sectors in the county historically, had significantly lost influence by 2003 as locals

\footnotetext{
359 "Agreement and Covenant Not to Sue (Boliden Intertrade)," ed. U.S. EPA (Washington, D.C.: U.S. EPA, 1990), 1, and John H. Hankinson jr., "Administrative Order on Consent for Removal Action at the North Potato Creek Watershed," in CERCLA Docket No. 01-11-C, ed. Region 4 U.S. EPA (Atlanta, Georgia: U.S. EPA, 2001), 4, and "Copper Basin Mining District, " U.S. EPA, http://www.epa.gov/region4/waste/copper/, accessed March 9, 2009.

360 "Report of Inventory and Characterization of Former Mining and Processing Areas and Materials Located on Public and Private Lands," ed. Waggoner Barge, Sumner, \& Cannon, Inc. (Ducktown, Tennessee: Glenn Springs Holdings, Inc., 2004), p. 2-2.

361 "Community Involvement Plan for the Copper Basin Mining District," ed. Community Involvement Partnership (Polk County, Tennessee: U.S. EPA, Tennessee Department for Environment and Conservation, Glenn Springs Holdings, Inc., 2001), 3-4.
} 
focused efforts on developing a second home/retirement market to capitalize on the "environmental resources of the area."362

Although Occidental Petroleum sold Cities Service in 1983 to the Southland Company, which by 1990 had sold it to the national oil company of Venezuela, Occidental remained the last viable district stakeholder with historic liability. ${ }^{363}$ According to the 2009 website of Glenn Springs Holdings, an Occidental Petroleum environmental subsidiary company:

In 1987 the EPA began investigating the site [the Copper Basin] and documented its negative environmental impact. Since the only remaining stakeholder was Occidental Petroleum Corporation, Occidental agreed to remediate the site in good faith in keeping with the company's commitment to environmental stewardship. ${ }^{364}$

Despite the seemingly effortless transition into remediation suggested by the above statement, fourteen years passed before Occidental Petroleum, EPA, and the State of Tennessee executed a formal consent agreement to clean up the basin. In fact, according to relevant authorities close to the negotiations, the EPA pushed hard to have the region placed on the Superfund National Priorities List (NPL), but Occidental fought the listing, fearing extensive litigation and attorney fees. The two reached agreement only after Glenn Springs, which had been working in the basin since 1997, finally "voluntarily" agreed to fund the clean-up, abide by EPA rules and guidelines, and reimburse EPA and the State of Tennessee for costs incurred. The EPA, in turn, agreed to let Occidental

\footnotetext{
362 "A Future Use Plan for Redevelopment of the Abandoned Mine Lands in Copperhill Tennessee," ed. Waggoner Barge, Sumner, \& Cannon, Inc. (Ducktown, Tennessee: Glenn Springs Holdings, Inc., 2003), 34.

${ }^{363}$ Southland Company is the parent to the 7-11 chain of convenience stores and sought ownership of Cities Service to provide a steady supply of gasoline to its stores. "Citgo Company History," CITGO Petroleum Company, www.citgo.com/aboutcitgo/companyhistory.jpg, accessed March 4, 2009.

364 "Copper Basin," http://www.glennsprings-copperbasinproject.com/history.htm, accessed March 7, 2009.
} 
manage the clean up and keep the operation from being federalized in an historic memorandum of understanding signed in 2001, and the State's Voluntary Cleanup, Oversight and Assistance Program (VOAP) kept Glenn Springs from potential long-term state-liability. $^{365}$

\section{Early Reaction to Environmental Degradation and Response}

It is true that citizens of Lower Wales and Southwest Montana complained about and sued copper smelters over lost vegetation and sick animals, and that smelter smoke court cases, newspaper accounts, and mining textbooks often cited barren landscapes surrounding smelters. Few regions, however, experienced the debilitating effects of landscape change as great as the Ducktown district. As noted in Chapter 4, the loss of woodlands surrounding Tennessee copper mining and smelting locations completely shut down the industry in 1878, and, following a resumption of mining and smelting in the 1890 s and legal and technical efforts to reduce sulfur emissions, district companies and Federal agencies began coordinating efforts to solve the landscape problem in the 1920s. While Michigan copper regions harvested significant amounts of timber for mining operations and Montana smelter smoke led to considerable vegetation loss, efforts to combat these problems usually resulted in court orders or municipal actions ending the injurious practice or damage awards to affected parties, not complete shutdowns. Tennessee

\footnotetext{
${ }^{365}$ Conversation with a Relevant Authority (1), Conversation with a Relevant Authority (2), and "Copper Basin Mining District Case Study: Use of Cooperative Agreements toward a Common Goal," ed. U.S. EPA (Washington D.C.: U.S. EPA, 2005), 6. Relevant Authority is a term used to protect the identity of individuals providing information during an oral interview. It is a university requirement.
} 
observers chronicled the problem more completely, and companies took actions to actually remediate the problems well before any other district.

This is not to argue that Tennessee corporations were more environmentally conscious than other mining companies. Rather the Tennessee copper district operations caused significant problems outside the region, especially noticeable after Franklin Roosevelt created the Tennessee Valley Authority (TVA) in 1933. TVA's jurisdiction extended over the entire Tennessee River drainage, including Davis Mill Creek and North Potato Creek, both of which ran through the Copper District, fed Ocoee River hydroelectric plants, and ultimately emptied into the Tennessee River. While the extra-regional awareness created by TVA resulted in funding for studies and remediation efforts, the conservation movement actually began in the region in the late1920s, and it is difficult to define what early drivers were present in Tennessee that didn't exist in other regions. Karen Daniels argues that the 1907 Georgia Supreme Court case created regional awareness and ignited the conservation movement, ${ }^{366}$ but court cases occurred in other areas, including Montana, Utah, and California that did not coalesce into a sense of community responsibility and a need to remediate the after-effects of smelting. ${ }^{367}$

Tennessee's landscape itself may have contributed to a stronger sense or perception of loss. The barren, red-soil lunar landscape of the Ducktown district sat in stark contrast to the thickly wooded green Appalachian forests that visitors traversed to

\footnotetext{
${ }^{366}$ Karen Daniels, Tennessee's Historic Copper Basin Area: An Overview (Benton, Tenn: Polk County Publishing, 1992), 13.

${ }^{367}$ Twentieth century regional conscience in Montana, however, was hard to gauge because by 1930 the Anaconda Company held considerable political power in the state, had sent its Copper Kings to the U.S. Senate, and owned several newspapers. Although similar power-structures existed with the largest smelters in Swansea, neither Michigan nor Tennessee mining/smelting companies enjoyed such influence.
} 
reach the district, strongly emphasizing the devastation. Similarly, Southern residents in general found greater identity with their Southern Culture and its agricultural roots than with industrialization often associated with Northern culture, and for a short time in the 1930s, a group of Tennessee scholars and writers called the "Fugitives" promoted an end to creeping industrial materialism and a return to traditional Southern agrarian values.

While this particular group did not foster much change and was largely washed out by the depression, it did contribute to a controversial agrarian manifesto, I'll Take My Stand: the South and the Agrarian Tradition, and reflected some deeply seated beliefs. ${ }^{368}$

Thus landscape devastation would have caused greater concern. Further, Michigan mines and smelters followed by Montana mines and smelters each led global copper production, creating a stronger regional/state-wide industrial identity and pride for the productive output of their districts. Big mines led to big production and greater population densities and diversities including the establishment of mining colleges that continued as technological universities after the end of most mining. Tennessee mines and smelters never produced at the rate of either Michigan or Montana, had more visible environmental problems and landscape degradation, and with strong regional agricultural identities, state and regional residents were more likely to react to landscape change than industrial production. In any case, writers, mostly non-locals, described the landscapechanges earlier than in other copper smelting districts, and companies tried to remediate the environmental effects earlier than other districts. Later local residents would try to

${ }^{368}$ B.C. Hall and C.T. Wood, The South (New York: Scribner, 1995), 224. 
preserve the desolate landscape as an element of their historic identity, earlier than their counterparts in other copper regions.

A short review of popular imagery from the $20^{\text {th }}$ century of the three districts also demonstrates key identity issues for the areas. Where regional Montana photographs and postcards show mining activities, smelting equipment, downtown buildings, and people, and regional Michigan photographs show miners, industrial structures, and shipping, popular Tennessee imagery is dominated by the denuded landscape. Both Montana and Michigan regions are depicted by the built environment. Tennessee is depicted mostly by environmental destruction. ${ }^{369}$ Not until the Superfund era and greater environmental consciousness did popular views begin to focus on environmental decline in Montana, mostly at the Berkeley Pit, while in Michigan this still has not occurred despite the Superfund cleanup.

The denuded Ducktown landscape was a direct result of mining and smelting operations, but M. - L. Quinn added twelve reasons why the landscape itself was partly to blame for the devastation. From isolated mountains with poor transportation routes, to high sulfide and pyrite concentrations, and high rainfall, humidity, and temperature inversions, the environment itself was not a passive victim, according to Quinn, but rather contributed to it own desecration. ${ }^{370}$

Environmental susceptibility is an identified condition whereby the environment of a particular location, because of the location's natural features, is especially

\footnotetext{
${ }^{369}$ This quick and unscientific study was conducted by searching for images and postcards at the Library of Congress website www.memory.loc.gov and www.google.com on April 3, 2009, under the terms "Ducktown, Tennessee; Copperhill, Tennessee; Butte, Montana; Anaconda, Montana; Houghton, Michigan; and Calumet, Michigan.”

${ }^{370}$ Quinn, "The Appalachian Mountains' Copper Basin and the Concept of Environmental Susceptibility," 185-186.
} 
vulnerable (is predisposed) to injury from specific human activity. Susceptibility, therefore, is a function of a site's natural features, but the basis for its determination is the manner in which those features interact, or could interact, with a particular human activity. ${ }^{371}$

In any case, the estimated loss of 50 square miles of forest and vegetation was formally recorded in 1929, and in 1944 the TVA estimated that Basin lands eroded at a rate of 39 ac-ft $/ \mathrm{mi}^{2} /$ year while the rest of the Ocoee River drainage averaged only $0.44 \mathrm{ac}-\mathrm{ft} / \mathrm{mi}^{2} / \mathrm{year}$. Further, by 1951, TVA had documented that in two separate 5 and 15 acre parcels, erosion had consumed a total of 1.8 and 1.9 feet of topsoil and subsoil over 17 years. All of that sediment, much of it contaminated with acids and heavy metals, found its way into the Ocoee River. ${ }^{372}$

Despite an early and clear understanding of vegetation loss and the effects of soil erosion especially during heavy rains, efforts to re-forest the basin and control sediment loss did not begin until 1929, when the Ducktown Sulfur, Copper and Iron Company (DSCI) sought advice from the U.S. Forest Service. With the Department of Agriculture it planted and/or distributed 3000 trees in 1930 with the assistance of the University of Tennessee extension service, and continued this practice in subsequent years. Although no clear reason for the company-sponsored revegetation emerges from the literature, Edward Johnson cited a 1929 Forest Service report that included a discussion of financial returns from timber production based on market demands and wood quality. While Johnson does not state whether this was the prime reason for tree-planting or a secondary benefit, the late 1920s economic decline in copper and acid production that ultimately led

\footnotetext{
${ }^{371}$ Ibid., 189.

372 Jack A. Muncy, "A Plan for Revegetation Completion of Tennessee's Copper Basin," ed. Division of Land and Economic Resources (Norris, Tennessee: Tennessee Valley Authority, 1986), 6.
} 
to the 1936acquisition of DSCI by TCC, may have forced the company to look for alternate means of income as its economic position declined. In 1973, a Cities Service report stated:

The land reclamation program carried out over more than 35 years by TCC and subsequently Cities Service has been carried out in the interest of better utilization of our natural resources (land) by putting it into productive forest land use as well as reducing possible siltation of surface waters in the Basin. This program has been carried out as a Company Policy and has been in no way connected with legal or administratively imposed requirements from any governmental body or Agency. ${ }^{373}$

Despite limited culpability or admission of responsibility, the company may also have been succumbing to political pressure or reacting to negative accounts of the landscape, problems with the TVA, or the potential threat of lawsuits.

Through the 1930s and 1940s, several groups including the Tennessee Extension Service, U.S. Forest Service, U.S. Bureau of Plant Industry, Civilian Conservation Corps (CCC), Federal Soil Conservation Service, TVA, and universities in Tennessee, Georgia, and North Carolina studied and worked to continue reforesting efforts the area but with only partial success because many early plants did not survive long enough to reproduce and establish new ground cover and forests. ${ }^{374}$ Between 1939 and 1950, the TVA, which had done little direct work on the Copper Basin erosion problem in the 1930s despite direct siltation effects on its two (at the time) downstream hydro-electric plants, took the lead in research, and with an established CCC camp in 1941 planted trees on the perimeter of the worst affected areas and experimented to determine which tree and shrub

\footnotetext{
373 "Engineering Report on Land Reclamation: Copper Basin - Polk County, Tennessee," Cities Service Company (Copperhill, Tennessee: Cities Service Company, 1973), 7.

${ }^{374}$ Muncy, "A Plan for Revegetation Completion of Tennessee's Copper Basin," 9.
} 
species grew best in the basin's acidic soils. ${ }^{375}$ In 1943, TVA built a third hydro-electric plant on the Ocoee. This one, just a few miles downstream from the basin, included a large reservoir to stem the flow of sediments and heavy metals to its further down-stream plants. ${ }^{376}$ According to Muncy, however, by 1973, sediment completely filled the Number Three hydro-plant reservoir, requiring occasional sluicing of sediments contaminated with heavy metals and acids downstream. ${ }^{377}$

TCC largely took control of the revegetation efforts from TVA in the 1950s and hired a professional agriculturalist to continue its tree planting program. ${ }^{378}$ Through the 1970s a variety of programs continued, each with some degree of success as acre by acre, the 32,000 acres of denuded landscape slowly shrank to 20,000 in 1943 to 12,000 in 1986 to close to 1,500 in $2000 .{ }^{379}$ While successful experiments with the "miracle legume" kudzu in $1956^{380}$ proved the plant to be a "competitive threat" to other flora, ${ }^{381}$ most new plantings included some combination of loblolly pine, Japanese fleece flower, or weeping lovegrass. Each of these demonstrated resistance to district toxins especially when augmented with new fertilizers, planting techniques, and, in the 1970s, rapid aerial seeding and feeding. Between 1950 and 1969, 4.5 million trees were planted, and

\footnotetext{
${ }^{375}$ Ibid., 10.

${ }^{376}$ M. L. Quinn, "Should All Degraded Landscapes Be Restored? A Look at the Appalachian Copper Basin," Land Degradation \& Rehabilitation 3 (1992), 118.

${ }^{377}$ Muncy, "A Plan for Revegetation Completion of Tennessee's Copper Basin," 8.

378 Ibid., 12.

${ }^{379}$ Kenneth J. Seigworth, "Ducktown-a Postwar Challenge: Can Man Correct a Century of Land Abuse in Tennessee's Copper Basin? A Start Has Been Made," American Forests 49, November (1943), 522; Muncy, "A Plan for Revegetation Completion of Tennessee's Copper Basin," 19; and "Copper Basin Reclamation Project," Tennessee Valley Authority, http://www.tva.gov/environment/land/copper.htm, accessed March 11, 2009.

${ }^{380}$ Mouzon Peters, "Healing the Scars in the Copper Basin," Chattanooga Sunday Times, September 2, $1956,1$.

${ }^{381}$ Muncy, "A Plan for Revegetation Completion of Tennessee's Copper Basin," 12.
} 
between 1970 and 1986, 6.85 million. ${ }^{382}$ By 1999 over 17 million trees had been planted since TVA-funded reforestation efforts had begun in $1941 .^{383}$ By 2008, most sources cited only one unvegetated 30 acre parcel, intentionally left denuded behind the museum that, because of dangerous subsidence from a mine collapse, could not be entered to remove the volunteer trees successfully reseeding. ${ }^{384}$ Although nearly 75 years of plantings have significantly reduced the desert appearance, a 2008 drive through the basin reveals a few remaining bare spots. ${ }^{385}$

About the same time as heavy revegetation efforts began, community awareness and activism crystallized at a rally of the Tennessee Conservation League held in the Copper Basin on May 27, 1950, organized for the kickoff of a state-wide "Keep Tennessee Green" campaign and to recognize the successful contributions of local industry. The speakers included Tennessee's Governor, TCC's General Manager, and regional historian R.E. Barclay among others. Several focused on the success of early reforestation efforts in the district, then about $50 \%$ recovered. ${ }^{386}$ Governor Browning remarked that as a nation "conservation of our natural resources must be our aim if we are to survive" and "that the human race is just 8 inches from starvation and one-half of this has gotten away from us," referring to lost topsoil in the Basin and reflecting the dust bowl just fifteen years earlier. TCC's general manager proclaimed that the copper company had only just begun remediating and pledged to "Keep Tennessee Green,"

\footnotetext{
${ }^{382}$ Ibid., 13.

${ }^{383}$ Edward A. Johnson, "Industrial Destruction Reversed at Copper Basin," National Woodlands 25, no. 2 (2002), 29.

${ }^{384}$ Conversation with a Relevant Authority (3), October 24, 2008.

${ }^{385}$ Personal Observation, October 24, 2008.

386 "Browning Is Speaker Saturday at Conservation League Meet," Copper City Advance, May 25, 1950, 1.
} 
while R.E. Barclay asserted, after describing the contributions of the copper company to community employment and taxes, that communities could rebuild lost houses and cars, but that without plants, it would surely perish. Probably the most telling observation and an early indication of changing directions in economic thought, however, came from C. P. Swan, State Commissioner of Conservation, who described how state-wide tourism had become a $\$ 225$ million dollar industry by 1949 , third only to manufacturing and agriculture, and with better managed green spaces, Swan saw no reason why that that amount could not be doubled. ${ }^{387}$ (See Figure 5.3)

Efforts to further sway negative, outside public opinion and convince observers and potential tourists that remediation was successful included a 1000-acre bluegrass and clover-covered demonstration farm that supported a 100-head herd of "purebred Aberdeen-angus" cattle, and a nine-hole golf course right in the heart of the district. These 1950s projects were designed mainly to serve as "proof that the soil [wasn't] as dead as some of it looks" despite the fact that TCC lost money on their operations. ${ }^{388}$

\section{Origins of Ducktown Heritage}

In popular articles titled "Ducktown-A Post War Challenge" (1943), "Healing the Scars” (1956), “Tennessee Valley Today,” (1973), “Copper Basin Cover-up” (1983), “Death of Ducktown” (1987), “Industrial Destruction Reversed at Copper Basin” (2002) and "Up from the Mines in Tennessee," (2007), journalists made a point of describing

\footnotetext{
387 "'Must Conserve Resources If We Survive," - Browning," Copper City Advance, June 1, 1950, first and last pages of section 1.

${ }^{388}$ Peters, "Healing the Scars in the Copper Basin," 1.
} 


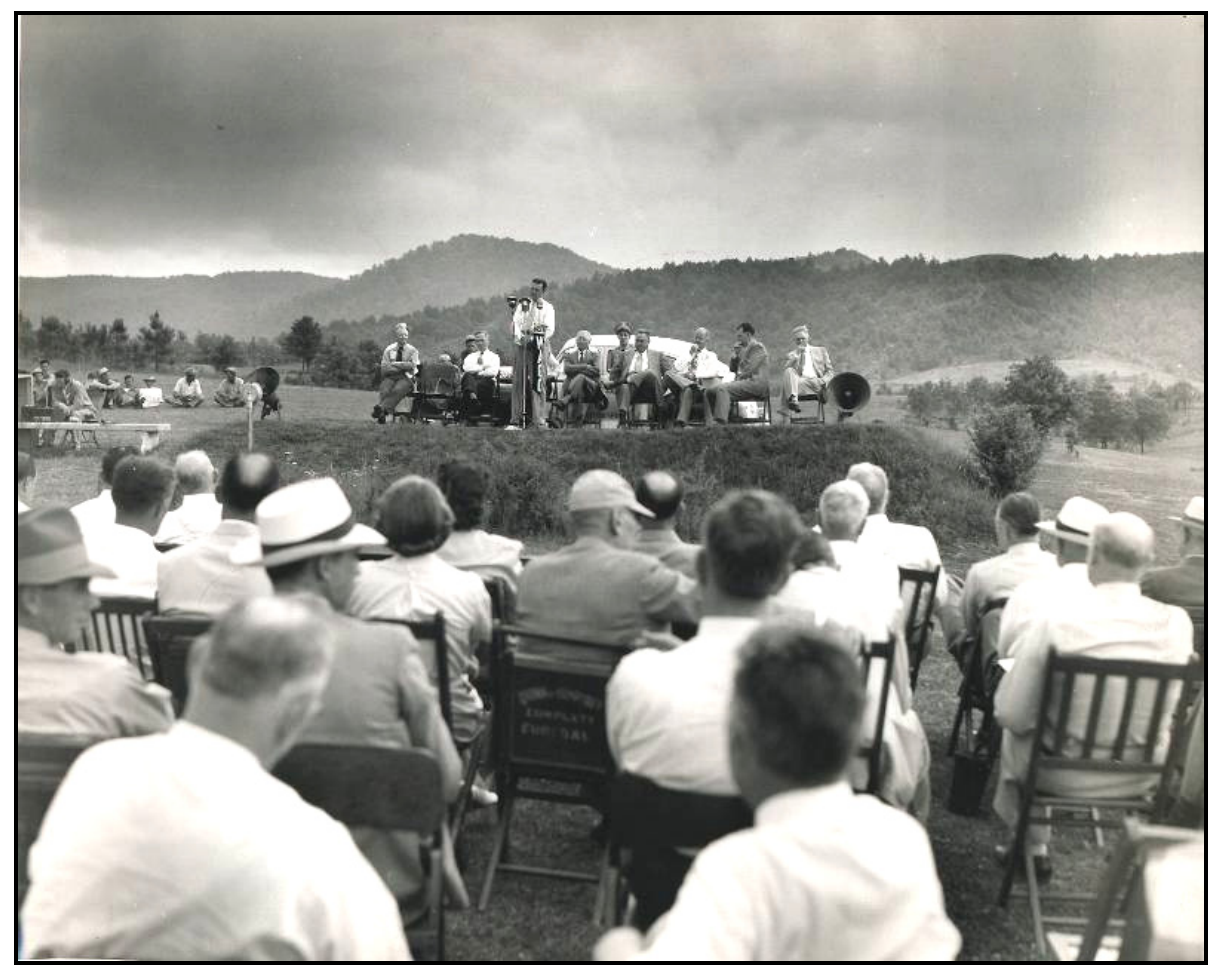

Figure 5.3 Conservation Rally in Copperhill, Tennessee, 1950 to kick off "Keep Tennessee Green" campaign. (Source Tennessee State Library and Archives website http://tnsos.org/tsla/imagesearch/index.php, accessed March 31, 2009.)

Ducktown as a landscape mired in environmental conflict and asserting that only near super-human effort had ultimately resulted in a resounding remediation victory. ${ }^{389}$ While these authors represented mostly an outsider perspective about the remarkable turn around in just 50 years, others questioned whether such a full restoration was of any value to district resident insiders.

\footnotetext{
${ }^{389}$ See Seigworth, "Ducktown-a Postwar Challenge: Can Man Correct a Century of Land Abuse in Tennessee's Copper Basin? A Start Has Been Made;" Peters, "Healing the Scars in the Copper Basin;" Clay Grady, "Copper Basin Cover-Up," Landscape Architecture 73, no. 4 (1983) 49-55; Young and Kristoff, "The Tennessee Valley Today;" Wilton Barnhardt, "The Death of Ducktown," Discover 8 (1987), 35-42; Johnson, "Industrial Destruction Reversed at Copper Basin;" and Chris Dixon, "Up from the Mines in Tennessee," New York Times, December 14, 2007.
} 
M. -L. Quinn, probably the most prolific writer on Ducktown since R. E. Barclay, wrote a 1992 article titled, "Should all Degraded Landscapes be Restored?" in Land Degradation and Rehabilitation Journal, complimenting four additional articles she wrote on the historical and environmental forces that shaped the Tennessee copper mining district's landscape. In her Land Degradation article, she reflected on the desires of some locals who felt a sense of loss because the heritage landscape they grew up with changed so dramatically as the restoration process neared completion. Quinn argued that all reforestation efforts should stop (as of 1992) until the extant mining/smelting landscape could be surveyed and documented for its unique and historically important characteristics and to determine if remediation efforts conflicted with or diminished the cultural and historical value of the Basin — similar to processes required by Federal projects under Sections 106 and 110 of NHPA. Quinn further called for independent historical assessments because TVA and the U.S. Forest Service had been too zealous in their reforestation efforts and the EPA's mission of protection and remediation rendered it incapable of objective evaluation. ${ }^{390}$

Similar themes surfaced in Barnhart's and Dixon's Ducktown articles, although these authors quoted residents mostly for literary contrast. Quinn's notions, however, reflected a growing body of literature questioning the extent and value of some remediation efforts. Archeologist Don Hardesty wrote "Issues in Preserving Toxic Wastes" (2001) in the Public Historian, specifically questioning the value of remediating all toxic sites, especially those that have recoverable archeological data or heritage value

\footnotetext{
${ }^{390}$ Quinn, "Should All Degraded Landscapes Be Restored? A Look at the Appalachian Copper Basin," 130131.
} 
and are not, of course, posing immediate threats to human life. ${ }^{391}$ Similarly David Robertson wrote in "Heaps of History" (2000) in the Journal of Illinois History, that despite their negative association to outsiders, there may be greater community value than harm in not fully remediating waste streams. In the case of Toluca, Illinois, he described how residents unanimously approved historic landmark status for "Jumbo," a massive coal mine waste pile. ${ }^{392}$ Even more critically, Fred Quivik questioned the very authority of the EPA to decide remediation treatment options in sensitive cultural areas in "Integrating the Preservation of Cultural Resources with Remediation of Hazardous Materials: An Assessment of Superfunds' Record" (2001) in the Public Historian. ${ }^{393}$ The issue of preserving a portion of denuded basin and counter efforts to fix the erosion problem drew considerable outside attention. Many district residents wanted to keep at least a part of their "beloved scar" 394 and a community survey conducted in 2001 quoted residents who wished to preserve the "moon-scape."395 Even as late as 2008, when most of the open acreage behind the museum was well on its way to volunteer reforestation, Ducktown's mayor still wanted, but didn't know how, to keep part of the small parcel free from trees to commemorate the region's history. ${ }^{396}$ (See Figure 5.4)

\footnotetext{
${ }^{391}$ See Donald Hardesty, "Issues in Preserving Toxic Wastes as Heritage Sites," The Public Historian 23, no. 2 (2001), 19.

392 See David Robertson, "Heaps of History: Toluca and the Historic Longwall Mining District," Journal of Illinois History 3, Autumn (2000), 184.

${ }^{393}$ See Fred Quivik, "Integrating the Preservation of Cultural Resources with Remediation of Hazardous Materials: An Assessment of Superfund's' Record," The Public Historian 23, no. 2 (2001), 47.

${ }^{394}$ Quoted in Dixon, "Up from the Mines in Tennessee."

395 "Community Involvement Plan for the Copper Basin Mining District," 4-5.

${ }^{396}$ Conversation with a Relevant Authority (4), October 22, 2008.
} 


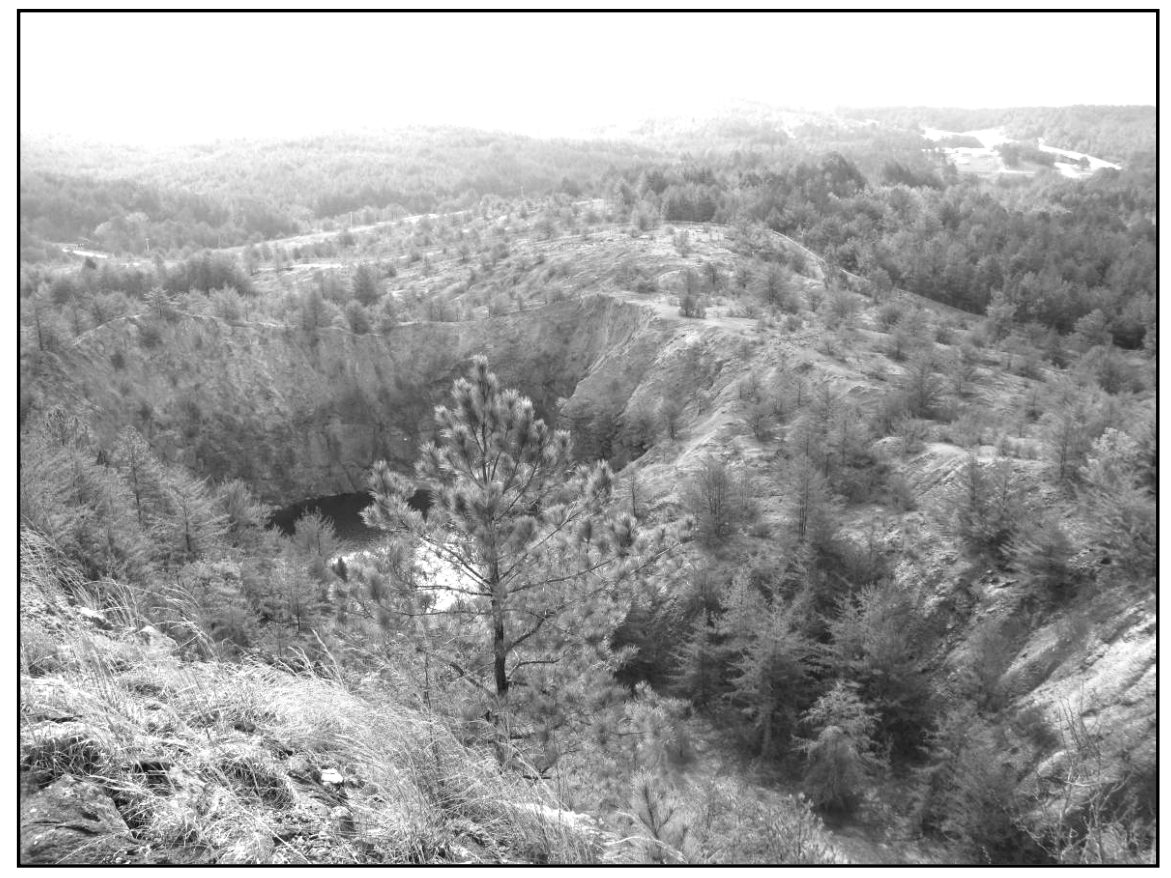

Figure 5.4 The 30 acre parcel behind the Ducktown Basin Museum in 2008 intentionally not revegetated to leave a reminder of the basin's once denuded landscape. However, because of the success of new species introduced, the parcel, off limits because of the visible mine collapse, is reforesting itself naturally. (Source: author)

But the quandary was to balance local heritage needs while overcoming the real and perceived ill effects of the region's mining and smelting past and somehow tap into the "4.5 million stressed out Atlantans, just two hours south" as potential short-term visitors. ${ }^{397}$ Unfortunately for the city of Ducktown, the 2008 north-bound excursion train from Blue Ridge, Georgia, and the south-bound train from Etowah, Tennessee, run on existing tracks and stop in Copperhill completely by-passing Ducktown. So although Ducktown has the commercial strip and museum, it doesn't have the built-in tourism

${ }^{397}$ Quoted in Dixon, "Up from the Mines in Tennessee." 
vehicle its sister city has. It thus struggles for regional identity and greater authenticity in its heritage planning. ${ }^{398}$

Like other rural mining districts, especially those that functioned for over a century and were in some state of economic decline, third and forth generation Basin residents sought to commemorate their heritage and celebrate the people and places that gave their region distinction. In 1978, an impromptu mining exhibit began in a Ducktown grocery store with some bartered artifacts. It ultimately grew into a more formalized museum where former workers and local residents gathered personal collections, stories, and photographs. Shortly after the museum opened, Cities Service abandoned the Burra Burra Mine site in Ducktown that served as the TCC surface headquarters from 1899-1976. In 1982, Cities Service donated the mine site to the Ducktown Basin museum, incorporated in 1978, as a historical monument and museum space. In 1988, the museum transferred ownership of the site and artifacts to the State of Tennessee, but continued to manage and interpret the mine site, artifacts, and local history. ${ }^{399}$ The museum soon occupied ten buildings on seventeen acres, including the office building, machine shop, and ore bin ruins and in 1983 the site was nominated to the National Register of Historic Places. ${ }^{400}$ Although the museum interprets environmental conditions and copper milling and smelting, it is primarily a mining museum and, with the exception of the attempt to preserve the small smelter-denuded lot behind the museum, does not fully address the complex and significant (both positive and

\footnotetext{
${ }^{398}$ Conversation with a Relevant Authority (4).

${ }^{399}$ Ron Clayton, "Ducktown Basin Museum Hits 30 with Plans to Keep Growing," Chattanooga Times Free Press, October 13, 2008, and Communication with Relevant Authority (3).

400 "Tennessee Historical Commission State Owned Sites," Tennessee Department of Environment and Conservation, www.state.tn.us/environmental/hist/stateown/ducktown.shtml, accessed March 9, 2009.
} 
negative) smelting operations of the district. Very similar mining museums operate in Butte, Montana, and Hancock, Michigan, but both of these districts have other, more formalized efforts to include part of the built smelting landscape.

The only other significant heritage movement before the remediation efforts came in the 1990s with multiple national register nominations for districts and sites in the Basin. The Southeast Tennessee Development District nominated the Ducktown and Copperhill downtown business districts and neighborhoods, the last-standing and regionally-unique Central Shaft mine head frame, and two individual non-industrial buildings to the National Register in $1992 .{ }^{401}$ With the exception of the inaccessible but highly-visible Central head frame, all nominated structures and districts, including the 1983-nominated Museum site, were publicly accessible. The more significant industrial site, the Copperhill smelter and acid and organic plants, however, were left off completely. Relevant Authorities suggest that planners discussed the potential of listing the site, but that they were discouraged by the smelter's Swiss operator, possibly because of unfounded fears of federal restrictions on site use. Further, the large active site might not have helped the kind of development regional authorities hoped for. From its website, The Southeast Tennessee Development District:

\footnotetext{
${ }^{401}$ See Karen Daniels, "National Register of Historic Places Registration Form: Central Headframe," United States Department of the Interior (Washington, D.C.: National Park Service, 1992), —, "National Register of Historic Places Registration Form: Copperhill Historic District," United States Department of the Interior (Washington, D.C.: National Park Service, 1992), —, "National Register of Historic Places Registration Form: Ducktown Historic District," United States Department of the Interior (Washington, D.C.: National Park Service, 1992), and —_, "National Register of Historic Places, Multiple Property Documentation Form: Historic Resources of the Tennessee Copper Basin," United States Department of the Interior (Washington, D.C. : National Park Service, 1992).
} 
provides and shares a staff to cost effectively plan, promote and implement programs that result in the development and improvement throughout the southeast region of the Tennessee River Valley Basin. ${ }^{402}$

While little evidence supports the assertion that the site may have been too ugly for inclusion, from the 1950 s to 2008 , tourism had been a key, if not the key, development issue for the Copper Basin, and the Copper Hill plant site with all of its disarray and destructive appearance, never quite fit well with the clean, controlled, and "attractive" appearance of its National Register-listed neighbors and shopping districts. In fact as heritage planning and remediation efforts continued after the Memorandum of Understanding was signed in 2001, the still-active Copperhill site continued to be largely excluded from heritage planning. ${ }^{403}$

\section{Superfund}

While the most visible effects of smelting operations in the Ducktown district were remediated by extensive tree planting over a 75-year period, few contemporary articles or studies mentioned the extent of "invisible" toxins remaining in the district until the advent of the Clean Water Act (1970), Resource Conservation and Recovery Act (1976), and Superfund (1980). From 1970 to 2001 several studies examined the remains of mining and smelting works in the district and determined the extent of environmental damage. At many locations heavy metals including copper, lead, iron, manganese, aluminum, and zinc, as well as acids, PCBs, and other chemicals remained in the soils

\footnotetext{
402 "Southeast Tennessee Development District," http://www.sedev.org/, accessed March 13, 2009

${ }^{403}$ The Copperhill plant was still operational at the time of the Memorandum of Understanding (MOU) and thus fell under other jurisdictional legislation aimed more at controlling active waste streams than remediating past pollution.
} 
from a century of operations. For example, one report listed the following contaminants, many carcinogenic, in one soil sample taken near the Isabella plant in 2004: 2-

Methylnaphthalene, Benzo(a)anthracene, Benzo(a)pyrene, Benzo(b)fluoranthene, Benzo(g,h,i)perylene, Benzo(k)fluoranthene, Chrysene, Fluoranthene, Indeno(1,2,3cd)pyrene, Naphthalene, Phenanthrene, Pyrene, Cobalt, Copper, Iron, Lead, Manganese, Selenium, and Zinc. ${ }^{404}$

Under CERCLA, the EPA retains the authority "to pursue long-term remedial response actions that permanently and significantly reduce the dangers associated with releases or threats of releases of hazardous substances." ${ }^{405}$ However, before EPA can act and spend federal money, it needs to first justify the extent of the damage, then initiate response actions and pursue those ultimately responsible to pay for it. From the EPA's description of the Copper Basin on its website (accessed March 13, 2009):

Mining and related activities have resulted in the environmental degradation of portions of the Copper Basin, including the North Potato Creek Watershed, the Davis Mill Creek Watershed, and parts of the Ocoee River. Waste materials from mining and processing activities remain as sources of contaminants in the form of acidic drainage and high levels of metals in the soils, sediments and surface waters of the watersheds that drain into and impact the Ocoee River. Acidic conditions and leaching metals have impaired water quality and deforestation has resulted in severe erosion. PCB containing oils have been released to the environment from abandoned transformers. Abandoned and collapsing mine works and other deteriorating facilities and waste piles also pose significant physical hazards. In addition, the lack of a healthy soil structure and the poor quality of riparian and upland ecosystems contribute to poor surface water quality. This has caused the degradation of large portions of the 10,000 acre North Potato Creek and the 3,000 acre Davis Mill Creek Watersheds and 26 miles of the Ocoee River. The two creeks that drain the Copper Basin Mining District site, when left

\footnotetext{
404 "Report of Inventory and Characterization of Former Mining and Processing Areas and Materials Located on Public and Private Lands," 4-13.

405 "Copper Basin Mining District Case Study: Use of Cooperative Agreements toward a Common Goal," 3.
} 
untreated, were releasing over 8,600 pounds of metals and greater than 19,000 pounds of acid into the Ocoee River every day. ${ }^{406}$

In most Superfund clean-ups, after determining a need for action, the EPA must list the locations on the National Priorities List (NPL). Once listed the EPA can initiate clean up actions with Federal funds based on a structured approach outlined in CERCLA and pursue the potentially and principally responsible parties (PRP) to pay/reimburse the government for the work, although it often attempts to identify a PRP before initiating action. In most PRP-funded clean-ups, the project is federalized and managed by the EPA, often with negotiated input from state and local officials and the PRP. Under such conditions other applicable laws pertaining to federal agencies must be followed, such as Sections 106 and 110 of the National Historic Preservation Act requiring mitigation of damages to significant cultural resources.

In the Copper Basin, the EPA sought to list the district on the National Priority List, but the issue was fought by Occidental Petroleum, the only remaining district stakeholder with liability. Despite arguing that it was not directly involved in any regional pollution, Occidental had purchased the company (Cities Services) that purchased the company (TCC) that, along with a company it bought (DSCI), was responsible for the majority of the pollution. ${ }^{407}$ Since the only other surviving district entities with any potential liability were either out of business (Tennessee Chemical

\footnotetext{
406 "Copper Basin Mining District," U.S. EPA, http://www.epa.gov/region4/waste/copper/, accessed March 13,2009

407 "Neither Glenn Springs nor its parent company, Occidental Petroleum Corporation, were ever engaged in any mining activities in the Copper Basin. Occidental Petroleum acquired Cities Service, Inc. after all mining operations had been sold to the Tennessee Chemical Company. Cities Service had acquired the Copper Basin assets from the Tennessee Corporation, which operated the Tennessee Chemical Company." See "Copper Basin," http://www.glennsprings-copperbasinproject.com/history.htm.
} 
Company), free from prosecution (Boliden Intertrade), or owned by a foreign nation (CITGO), Occidental ultimately realized a prolonged fight would entail considerable legal fees. Further, presuming even more legal fees associated with an EPA-managed Superfund clean up along with the negative tourism and development impacts for a district associated with Superfund, Occidental agreed to assume full financial and managerial responsibility for the clean-up, accept federal monitoring, reimburse the government for its cost, and abide by the general Superfund procedures and protocols outlined in CERCLA in exchange for operational control and the agreement, that as long as the clean-up followed Superfund guidelines and activities approved by EPA and/or Tennessee Department of Environment and Conservation (TDEC) under a voluntary cleanup and assistance program (VoAP), the operation would remain private. ${ }^{408}$

Although the clean-up remained private, Occidental entered into a legally binding Memorandum of Understanding with EPA and TDEC to enforce the clean-up order. ${ }^{409}$ Similar to federalized Superfund clean-ups, potentially responsible party (PRP) funds supported studies to determine the extent of damage, proposed and executed clean-up actions, and promoted community involvement in the decision process. A certain portion of the money expended was also contributed directly to community projects as reparation for damages caused and loss of quality of life. Occidental, through its Glenn Springs subsidiary, contributed significantly to district projects. It funded annual picnics and site tours, funded museum projects, developed a Community Involvement Plan, provided

\footnotetext{
${ }^{408}$ See Timothy Fields, "Memorandum of Understanding between Tennessee Department of Environment and Conservation, U.S. EPA and Oxy, Inc.," in CECRLA Docket No. 01-10-C, ed. U.S. EPA Region 4 (Atlanta, Georgia: U.S. EPA Region 4, 2001).

${ }^{409}$ See Ibid.
} 
funds for the community to hire technical experts to assist it in participation, and provided scholarships to district students attending state universities. ${ }^{410}$ However, unlike federalized projects, Glenn Springs and the EPA argued when pressed, this clean-up was not legally bound to follow laws that applied to government activities or government property, such as Sections 106 and 110 of NHPA, and no federal agency or the State of Tennessee pursued the issue further.

EPA divided the region largely into three main components in the memorandum of understanding (MOU), each a separate watershed emptying into and including the Ocoee River. (See Figure 5.5) The North Potato Creek watershed encompassed most of the original mining lands, the open pits, and the towns of Ducktown and Isabella, including the substantial smelter and acid complex that was largely abandoned by 1987. The Davis Mill Creek watershed included some later mining activity but bisected the Copperhill site that was active in some capacity through 2008. Although Glenn Springs, as outlined in the MOU, removed a substantial slag deposit adjacent to the Ocoee River in Copperhill and implemented water-treatment plans and water diversion controls to contain metals and acid run off from Copperhill and significantly reduced contamination, most of the clean-up activity focused on the North Potato Creek watershed because Davis Mill Creek still contained operating industry governed by other laws. ${ }^{411}$

\footnotetext{
410 "Copper Basin Mining District Case Study: Use of Cooperative Agreements toward a Common Goal," 6 and Conversation with a Relevant Authority (1).

411 "Copper Basin Mining District," U.S. EPA, http://www.epa.gov/region4/waste/copper/, accessed March $13,2009$.
} 


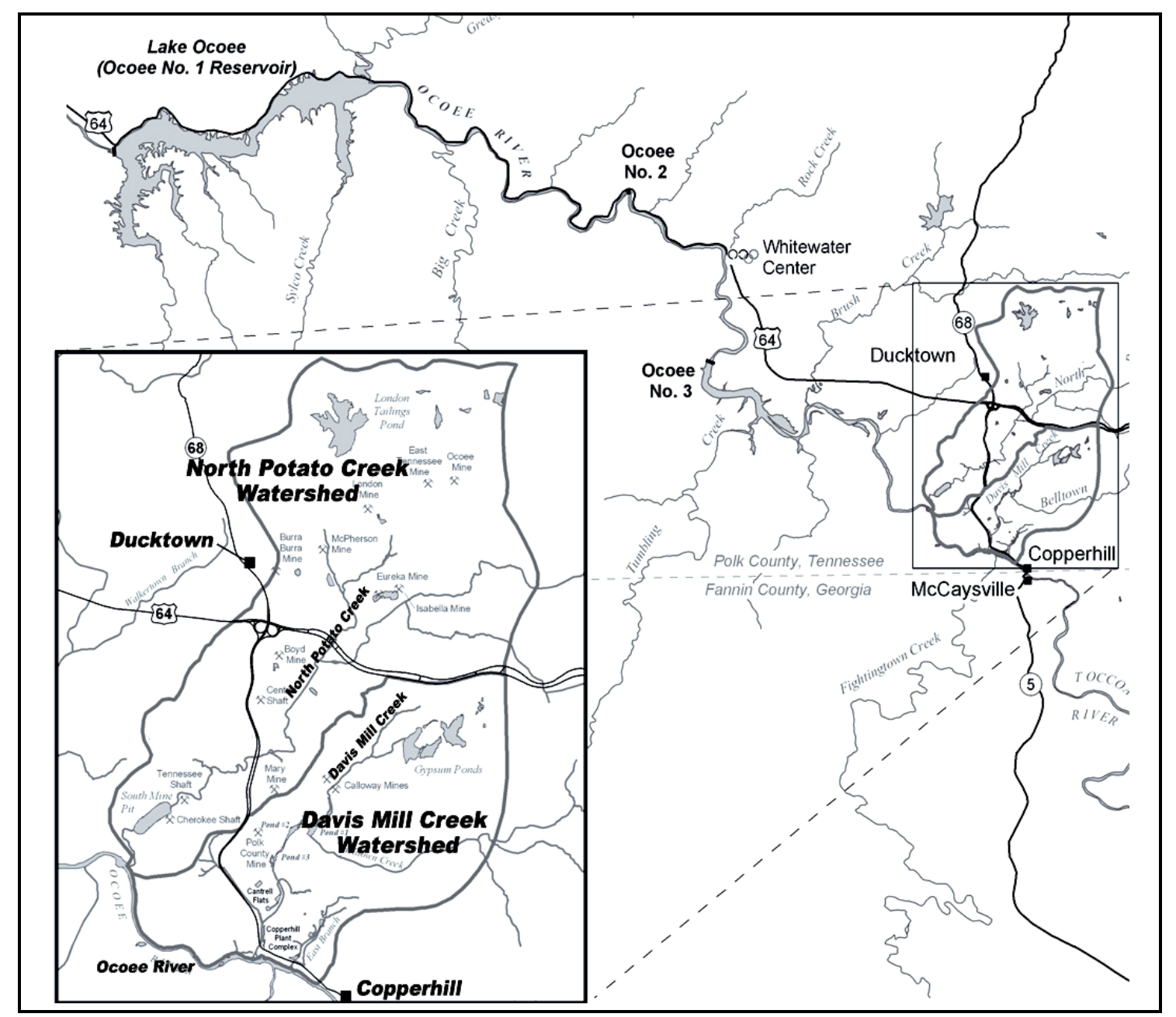

Figure 5.5 Copper Basin Mining District showing North Potato Creek and Davis Mill Creek watersheds. (Source: "EPA Proposes Action on Davis Mill Creek," 2003, 3)

Ultimately, much of the remediated area in the North Potato Creek watershed will be converted to public park land with hiking and biking trails, and some heritage interpretation with the Ducktown Basin Museum serving as the park trustee much in the same way it manages the state-owned Burra Burra mine site. ${ }^{412}$ By 2008, Glenn Springs had already capped the lead contaminated soils surrounding the Isabella acid plants, and

${ }^{412}$ Conversation with a Relevant Authority (3). 
capped and revegetated the former Isabella slag dump and tailings pond. It had fenced all of the collapsed mines, removed PCB- contaminated soils, and deposited non-hazardous acidic wastes into the flooded Isabella mine collapse for "sub-aqueous" disposal. Glenn Springs had also built water treatment plants at the South mine pit to process North Potato Creek waters, pumped and treated water from flooded mines, and built an experimental wetland to explore natural water treatment alternatives. All told, according to an EPA website, the water treatment plants in the Copper Basin have removed 16 million pounds of metals and neutralized 28 million pounds of acid. ${ }^{413}$

\section{Heritage}

An important part of any Superfund clean-up, whether publically funded or privately managed under consent decree, includes public participation. Glenn Springs in the original MOU agreed to develop and execute plans for public involvement in remediation, education, and future use decisions for the remediated lands. The first page of the October 2001 Community Involvement Plan, created by the Community Involvement Partnership that included TDEC, EPA, and Glenn Springs, stated the partnership's mission was to "provide consistent, accurate, and timely information, and to listen and respond to concerns from citizens." ${ }^{414}$ In addition to explaining the process and legal framework Glenn Springs would follow in remediation, it also included a section outlining community concerns, ultimately resulting in a 2003 Future Use Plan.

\footnotetext{
413 "Copper Basin Mining District," U.S. EPA, http://www.epa.gov/region4/waste/copper/, accessed March 13, 2009.

414 "Community Involvement Plan for the Copper Basin Mining District," coversheet.
} 
The Community Involvement Plan listed six areas of primary public concern: the cleanup effects on current and future economic conditions, the need for preservation of the unique and historic region, the availability of remediated lands for future use, compromised aesthetic land values for future uses, potential site-related health and environmental problems, and the cost and duration of clean-up activities. ${ }^{415}$ In general, most residents were happy with the remediation plan proposed and had only minor questions about health and safety issues. Other public viewpoints included relief that the region was kept off the National Priorities List (NPL) avoiding the potential negative affects on the tourism-market, and a strong desire to preserve the unique character of the region and create new recreational opportunities linked with historical and environmental education programs. Still, long-time residents voiced wishful regret that "the unique moonscape" and deforested red hills could not be preserved. However, "most residents [accepted and many welcomed] the reforestation efforts that... restored the tree cover over the last few decades." ${ }^{416}$

Two years after the Community Involvement Plan, Glenn Springs submitted a Future Use Plan to "outline the decision-making process for restoring the Lower North Potato Creek Watershed to a condition that is protective of human health, safety, and the environment; and provides for re-development of the site so that it becomes an economic as well as environmental asset to the surrounding communities." ${ }^{\text {"17 }}$ This plan only applied to abandoned properties in the district and not to the then-active corridor through

\footnotetext{
${ }^{415}$ Ibid., 4-4.

${ }^{416}$ Ibid., 4-5.

417 "A Future Use Plan for Redevelopment of the Abandoned Mine Lands in Copperhill Tennessee," 1.
} 
Copperhill. A significant portion of the report focused on economic development, especially tourism, and broke down the demographics of regional visitors and the extent of monetary expenditures in the area. Most of the plan's new development ideas were geared toward tourism and included new hotels, shopping, and restaurants. ${ }^{418}$

According to the Future Use Plan, two primary factors shaped the "sense of place" in the Copper Basin, Ocoee River, and Cherokee National Forest areas: nature and outdoor activities, which the reforested lands complemented, and the mining heritage that defined the region's historic identity echoing the long-standing landscape conflict between mining and nature in the district. While the recreational attributes of the region were well established and growing, the plan admitted that, outside of the Museum, "very few historic places remain and none currently provide interpretive opportunities. ${ }^{\circ 419}$ Of the "few" historic places remaining, the plan cited the structures on the National Register and the three Ocoee powerhouses and dams, but also called for additional heritage preservation, specifically citing the Central Head Frame and Hoist House, Isabella building and acid tank foundations, and parts of the original Old Copper Road. Noting that restored sites fit into a general upswing in nostalgia-based tourism, the plan called for additional thematic developments, such as the historic excursion railroad, addressed specifically to visitors.

Summing up the importance of heritage to visitors, the Future Use Plan stated: "preservation of cultural landscapes such as the barren areas near the Ducktown Basin Museum and the mining structures are important, and displays of how the environment

\footnotetext{
${ }^{418}$ Ibid., 10-12.

${ }^{419}$ Ibid., 12.
} 
and the people were shaped through the mining activities should be included in the site design." 420 The Future Use Plan recognized the community's desire to include heritage in any sort of redevelopment and its understanding that tourism was a key factor in future economic growth. It also demonstrated the commitment of Glenn Springs Holdings to the community and its desire to be a more positive corporate citizen, despite accepting financial responsibility for pollution cleanup while declining any culpability.

Despite Glenn Springs’ significant financial contributions to community programs, however, the Tennessee Copper district was beset by complications to heritage planning. Heritage preservation in general is not a simple task, and the decisions about what to remember/commemorate/preserve are contested based on relative perceptions of value. A mill building may be seen by some as an important reminder of what made the region they live in significant, while to others it may look like an old dilapidated structure taking away from natural beauty.

Both Ducktown and Copperhill recognized the importance of retaining their historic character if they were going to attract the kind of tourism and economic development they saw as their only viable means of income after their industry departed. While the Ducktown Basin Museum and the Copperhill excursion rail terminals both contribute to that end, the district is missing a structured approach to broad heritagelandscape management. Tennessee had (and has) its heritage champions, but its relatively small copper output ultimately did not generate the type of population density that fosters the formation of large, well organized heritage groups. Polk County (TN)

${ }^{420}$ Ibid., 12. 
only had a 2007 estimated population of 15,000 , no university or college to draw in new community members, and largely had dedicated individuals, as opposed to organizations, promoting heritage projects. ${ }^{421}$ The Tennessee Copper Basin, unlike the Michigan and Montana copper districts, had little means to bring in new people outside of tourists and people seeking vacation homes.

Tennessee's Copper Basin heritage champions, moreover, are beset with additional complications. Because the cleanup is privately-funded on private land, there is no legal requirement to consider cultural resources under Sections 106 and 110 of NHPA, and therefore decisions about preservation are left to the groups managing the clean up. This does not necessarily mean that the cleanup organization and its public monitors do not want active preservation. Quite to the contrary, they do, but they do not base decisions on National Park Service-defined levels of significance but rather on practicality without a strong professional heritage group assisting.

Ducktown's mayor, the museum director, and relevant authorities close to the clean up have all expressed desires to keep part of the built mining landscape, interpret it, and make it accessible to the public. However, without a legal structure and formal procedure as outlined in NHPA, the greater expense of preservation over demolition, and the fact that simple steel or concrete structures are easier to care for than more complicated buildings, dominate decisions. Which things get saved largely boils down to the cost of preservation and long-term maintenance rather than to issues of significance. Under Sections 106 and 110, important structures too damaged to retain would at a

421 "USA State \& County Quickfacts," U.S. Census Bureau, http://quickfacts.census.gov., March 24, 2009 
minimum receive some sort of documentation prior to demolition. This is not to suggest that Glenn Springs Holdings avoids the issue of preservation, but rather as the funder of an expensive clean up whose mission is primarily to remediate the environment, its decisions are based heavily on economic considerations.

The Ducktown Basin Museum director faces similar constraints. Ultimately, the remediated land will be managed under a trusteeship by the Museum. As the only heritage professional directly or indirectly involved in the project, the director can offer opinions on a structure's historical significance, but has little direct influence over the process to select which structures get preserved. He is further constrained by the future responsibility of caring for the old structures and the potential liability of dangerous structures. While mill buildings and smelter foundations may be historically and culturally significant, they ultimately will be very expensive to maintain, especially for a small regional museum with a limited budget. ${ }^{422}$

The selection process for preservation thus becomes very simple in this case. Many decisions about heritage preservation are agreed to by handshake based on windshield surveys and discussions about the demolition and clean-up costs, public accessibility, structural stability, health and safety, and long-term needs. While these are all appropriate considerations for preservation discussions, without significance being considered first, the preserved structures are largely limited to concrete bins, masonry retaining walls, some foundations, and simple steel structures such as the Central head frame.

\footnotetext{
${ }^{422}$ Conversation with a Relevant Authority (3).
} 
Although few could argue against the heritage significance and value of the Central head frame, other head frames, and museum buildings, some of the other structures slated for saving have less significance in their existing context. For example, the partial remains of the concrete fine ore bins at the London Mill site are being kept. The site of the cleaned bins in their now-grassy field has stunning beauty similar to Stonehenge in the United Kingdom (especially on a sunny summer day), but much of the ore bins' heritage value is lost because they will be the only historic structure left of a once very large and important milling complex. Without a larger context of surrounding buildings or at least foundations, the bins are isolated megaliths in a beautiful setting, belying their own importance and incapable of relaying the historic processes that took place there without extensive interpretation. (See Figure 5.6)
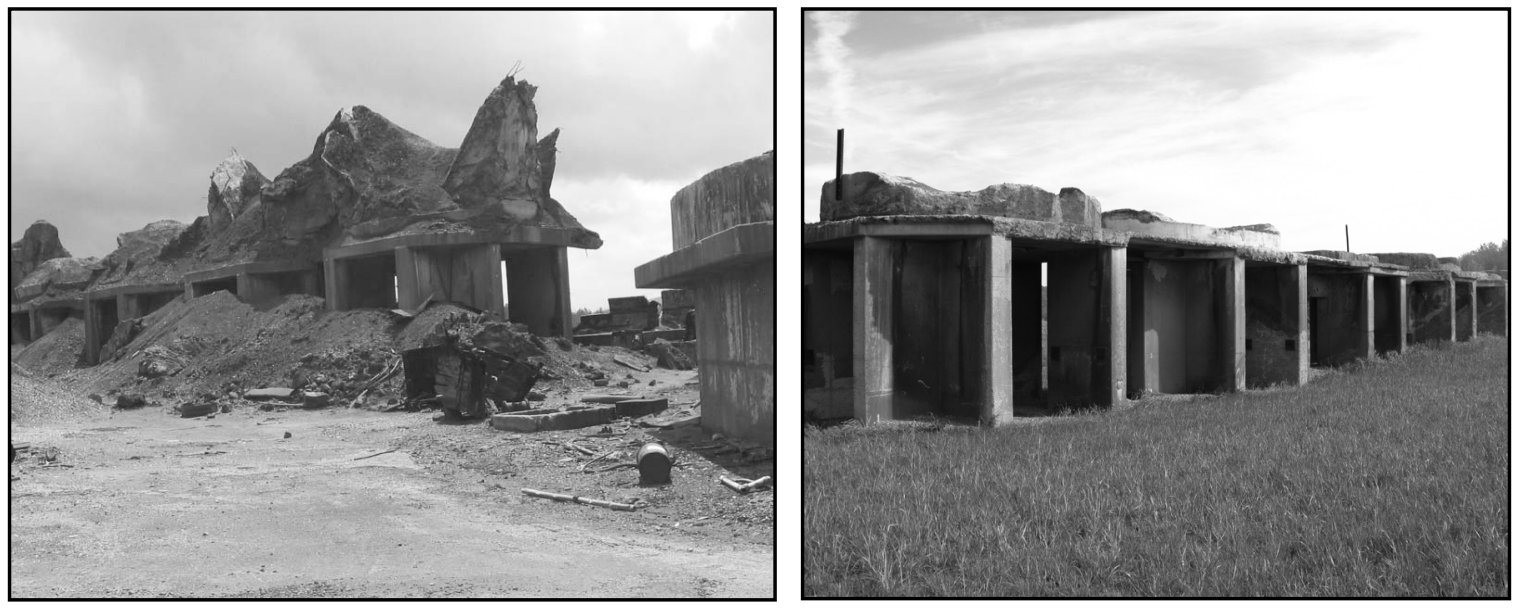

Figure 5.6 Fine Ore Bins at the London Mill site before restoration (ca. 2000) and after in 2008. (Sources left: EPA "Copper Basin Mining District Case Study: Use of Cooperative Agreements toward a Common Goal," (2005), 1 and right: Author) 
The decision to save only the fine ore bins reflects the nature of heritage preservation in the Tennessee Copper Basin. The bin's cleaning costs actually exceeded demolition costs, reflecting some compromise with full remediation. But the desire to economically neutralize contaminants associated with chemically hazardous processes at other buildings in considerable disrepair at the site led to the demolition of the remainder of the facility and thus the loss of the bin's heritage context. ${ }^{423}$ Given a more structured, rather than narrow, short-term approach to heritage planning, decisions that included greater considerations of cultural and historical significance might have resulted in a more complete industrial landscape.

Further, there is no iconic symbol left in the district. No single entity in the Copper Basin serves as a replicateable and brandable banner image. Although the Central Mine head frame comes closest in terms of visibility and recognition by locals, it is not used as consistently as landmarks in other districts. Unfortunately, the one iconic feature commonly associated with the Basin, the denuded landscape that appeared in myriad photographs and articles for a century, is all but gone.

\section{Smelter Heritage}

The comparative focus of this dissertation is three copper smelting sites in larger mining heritage contexts. If by definition, smelting includes every process after milling, then roasting, smelting, and refining and relevant by-products must also be included. Therefore, the region affected by smelting in Tennessee includes the entire area denuded

\footnotetext{
${ }^{423}$ Conversation with a Relevant Authority (1).
} 
by open-heap roasting, and the effort to preserve the small patch behind the museum should be similarly included as smelter heritage along with acid production and the smelters themselves.

The Isabella smelter site, historic home to significant developments in pyritic smelting technology and the construction of large acid production facilities, is among the most contaminated in the Basin. Near Isabella are the historic roasting yards of the Buena Vista mine and near Ducktown, the McPherson Roast yards, both of which are also considerably contaminated with heavy metals and acids. All three locations were significant to the smelting and mining heritage of the region: the two roast yards for the smelter smoke they generated that led to the lunar landscape and the Isabella smelter plant for its technology.

Much of the Isabella site, however, was dismantled during the 1970s when metal and acid production was fully moved to Copperhill. It was further damaged by the nearby mine collapse that is now serving as sub-aqueous storage for slag waste. The acid plants resulted in considerable lead deposition in the soil, estimated at more than 1,400 tons. ${ }^{424}$ Part of the approved remediation plan involves covering the contaminated soil with an impermeable cap to eliminate potential human exposure. Other potential contaminants at Isabella have either been removed, covered, or in the case of slag, dumped in the pit, leaving little available for historic interpretation. The contamination of the area is without doubt, but slag piles and debris that pose minimal human health hazards and sound structures are being saved in other districts, even if in a ruined state.

\footnotetext{
424 "Report for the Extent of Lead Contamination at the Former Isabella Lead Chamber Acid Plant, Ducktown, Tennessee," 2.
} 
Other significant Tennessee structures and features might have been saved too if a more structured approach had been attempted. (See Figure 5.7)

The other significant smelter location at Copperhill has more potential for heritage preservation, but it too is in the process of being dismantled by the company operating the site. Because the Copperhill location was active at the time of the memorandum of understanding and not under the jurisdiction of CERCLA, the plant was not included in the original clean-up plan and therefore not considered for heritage planning. Because the State of Tennessee is not interested in pursuing heritage considerations in the midst of a complicated non-federalized cleanup, little will likely be done to preserve any of the significant foundations or remaining structures of what was once the largest acid production plant in the world. (See Figure 5.8)
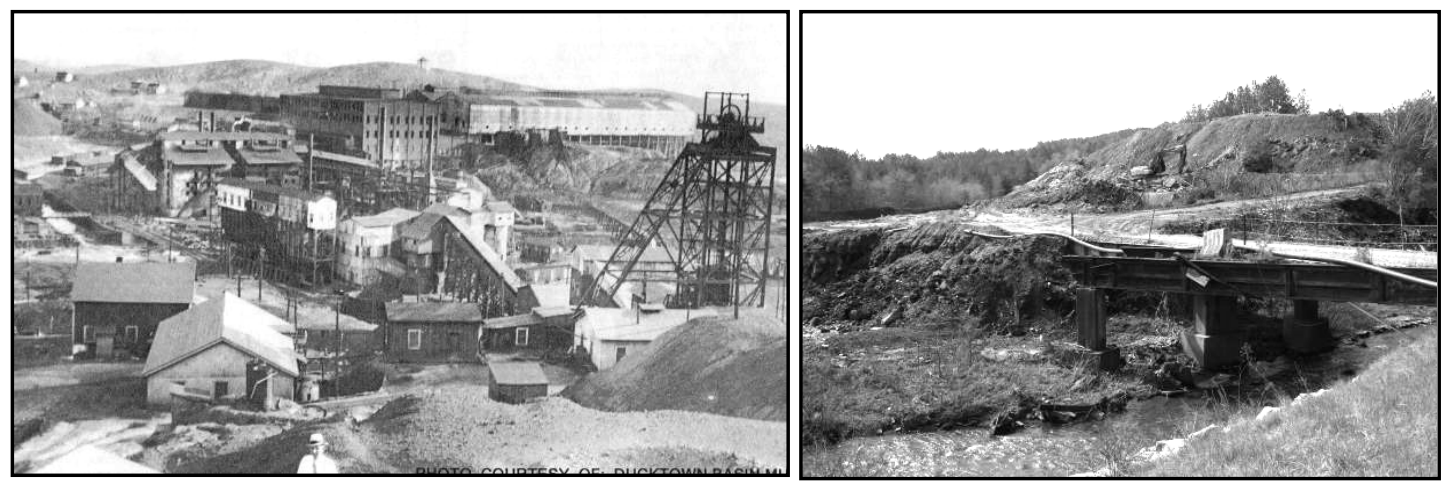

Figure 5.7 Isabella ca. 1945 and 2008. (Sources left: "Copper Basin Pictorial Calendar" (2008), right: author) 




Figure 5.8 Copperhill smelter and acid plant as it looked in April 2008 after years of successive demolition and removal projects. (Source: author)

This is not to imply that Glenn Springs is not interested in contributing to the heritage of the district. Its intentions, efforts, and contributions are well documented. It is simply not bound to consider damages or impacts to properties eligible for the National Register. In general, its decisions are made on the basis of practicality and not on historical significance. Ultimately, nearly the entire remediation project area will be converted to park with walking and biking trails augmented by some historic features. But the features selected are being chosen for their durability based not on study or systematic heritage planning, but on hand-shake agreements following windshield surveys.

In the summary document of the Future-Use Plan submitted to foster public discussion, the authors assert that the future-purpose of the remediation is to "develop revenue generating" recreational assets to attract tourism to the Ducktown/Copperhill 
region and the State. "Improvements would encourage cultural, historic, and environmental tourism through enhancement of historic mining features and would be important to the region's economy." ${ }^{425}$ Specific projects included constructing walking/biking trails, developing interpretive trails and outdoor classrooms to educate the visitor on mining operations, post-mining stewardship practices, and natural history, improving educational facilities at the Ducktown Basin Museum, pursuing greater national historic recognition, and establishing redevelopment/enterprise zones in Ducktown and Copperhill to encourage mixed-use office and festive/thematic retail development, and establishing excursion rail service from Blue Ridge, Georgia, and Etowah, Tennessee. ${ }^{426}$

Although a part of the North Potato Creek site will be converted to an industrial park, the fortunes of the county are geared squarely on tourism development. ${ }^{427}$ With a substantial population in Atlanta just two hours away and sizeable populations in Chattanooga just one hour away and Nashville only three hours away, and proximity to the Appalachian Mountains and Great Smokey Mountains National Park, the Copper Basin seems like an ideal location, and heritage is at the top of the list of attractions. Although the smelter landscape is largely conglomerated into the broader mining landscape, its historic effects will still be visible despite significant improvements in ground cover. A few small plots of land that do not take to reforestation are exposing stark red soil amid the green canopy, while the intentional plot of denuded land is self-

\footnotetext{
425 "A Future Use Plan for Redevelopment of the Abandoned Mine Lands in Copperhill Tennessee," detached one-page summary.

${ }^{426}$ Ibid., detached one-page summary.

${ }^{427}$ Conversation with a Relevant Authority (4).
} 
foresting. Interpretive signs will increase the visitor's understanding of the historical processes that shaped the district.

The individuals working to save and interpret some of the historic structures of the Basin should ultimately be commended for their efforts. Much preservation in this country is geared toward tourism, and with luck the two will go hand-in-hand. Moreover, it is hard to assess how the experiential sensation would be different had a more structured approach to significance been applied to determining what parts of the landscape were retained, or how more structured interpretation would combat the stark realization of some inquisitive visitors who, after a period of time hiking and biking in the Copper Basin woods, are suddenly struck by fact that all the trees are exactly the same and all the grasses are exactly the same and all the bushes are exactly the same.

If a single underlying theme were identified to tie the history of the Ducktown District together from the first mining, through the cleanup and heritage plans, it would be the idea of the landscape and the land and the on-going conflict with mining or later, mining heritage. From the beginning the landscape and its characteristics, what M. -L Quinn called environmental susceptibility, defined and even drove human interaction more than any other factor outside of economics. The region's remoteness contributed to the first two shutdowns. Further its geologic basin features tended toward temperature 


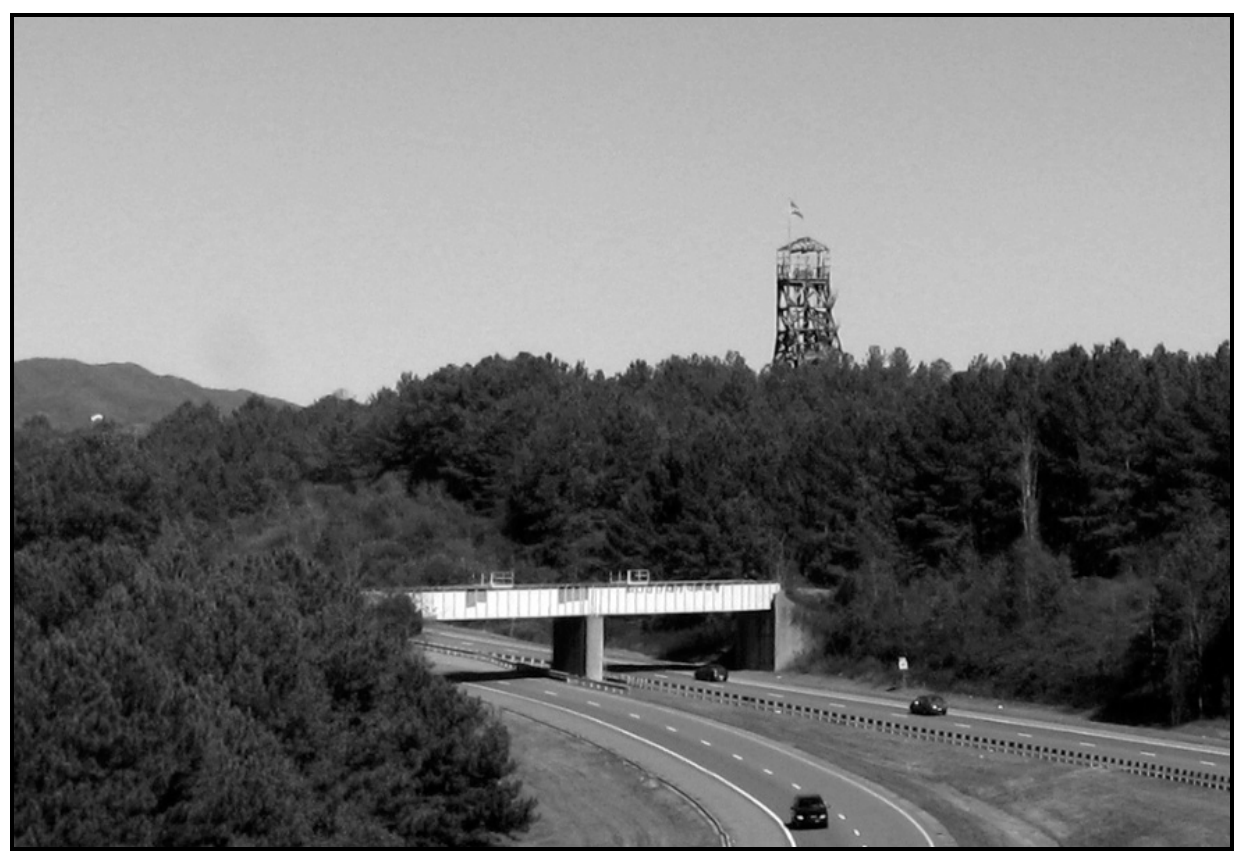

Figure 5.9 Central Shaft 2008 towering above State Highway 68 between Ducktown and Copperhill, Tennessee. (Source: author)

inversions and limited wind, holding in smelter smoke and contributing to the substantial denuded moonscape. The smoke from the land's sulfur-rich ore killed vegetation and elevated erosion, leading to significant toxin and sediment problems for the Ocoee River, which, as part of the landscape, generated power for businesses and homes, and prior to mining and smelting pollution, provided fish for food. The ore's high sulfur enhanced the development of pyritic smelting and created a need for sulfuric acid plants both to protect the land and, through fertilizer production, enhance the growing capacity of the land. The first remediation treatment, tree planting, was in direct response to the landscape degradation, and later remediation efforts ultimately resulted in a substantial wooded park, whose sheer size and long-term management challenges are affecting heritage decisions. 
The other key issues affecting Ducktown District heritage are the privatization of the cleanup effort and the relatively small and isolated community. The fact that the cleanup is private makes many of the active stakeholders' jobs relatively easier when it comes to placing priority on remediation over preservation. The EPA can carry out its mission to protect human health and the environment through MOUs and Consent Decrees while not having to be formally distracted by legal considerations for heritage. The cleanup company can largely focus directly on the clean up and choose how it wants to engage the community. In terms of public relations, this allows it to respond directly to specific needs of the broad community and not necessarily become embroiled in controversial heritage decisions. The company is preserving some structures, as well as contributing financially to many other community projects, and most people in the region are quite happy with the company's efforts.

It is difficult to argue that the State of Tennessee is not interested in historic preservation, but with limited budgets and staffing, the State Historic Preservation Office is likely a little relieved that it, too, is not embroiled in assessing significance and enforcing Sections 106 and 110. Certainly the Ducktown Museum would like to retain a greater portion of structures in the remediation area, but it suffers from limited budgets and staff, and already has a fairly stable collection of mining structures, so the fewer new buildings to take responsibility for, the easier it will be for the museum in the long-run. Overall, it is difficult to determine how negotiations with the clean up company would have evolved if the EPA had been forced to ensure much broader heritage planning and enforce payment for greater historic stabilization projects and long-term care. 
Moreover, the small population of the Copper Basin means that organized preservation groups are small. Had the mining district been more significant nationally in terms of production, then the small preservationist contingent might have had a stronger voice for greater preservation. Had more of the nationally significant smelting structures like the Herrshoff pyritic furnaces or part of the world's largest acid plant survived, then preservationists might have had a stronger voice, even if the complexity of remediation and preservation increased significantly. Had the region not been as polluted over 100 years by copper mining and processing, maybe more outsiders would have been interested in visiting and more structures in the contaminated areas could have been saved. But with only a handful of people driving heritage with tourism as their main goal, and a general satisfaction with the clean up progress, the community is getting what it ultimately argued for-despite largely top-down heritage decisions.

The approach to heritage in Tennessee is largely an a-historical and skewed, topdown process with EPA and Glenn Springs making the majority of the decisions as opposed to heritage professionals. This, however, is not the only approach. Montana has been largely a bottom up process with well organized local groups and members of the community largely deciding what they want in terms of heritage, then negotiating with the EPA and the PRP to get it. 


\section{CHAPTER 6. MONTANA}

The city wasn't pretty. Most of its builders had gone in for gaudiness. Maybe they had been successful at first. Since then the smelters whose brick stacks stuck up tall against a gloomy mountain to the south had yellow-smoked everything into uniform dinginess. The result was an ugly town of forty thousand people, set in an ugly notch between two ugly mountains that had been all dirtied up mining. Spread over this was a grimy sky that looked as if it had come out of the smelters' stack.

- Dashiell Hammett, 1929 (Red Harvest, 3-4)

ARCO save that stack, touch not a single brick

Signify the livelihood that made Anaconda tick.

Still let it stand there stark against the sky,

Like a somewhat obscene gesture catching every eye.

-Tom Dickson (quoted by Mercer 2001 Anaconda, 216)

November 9, 2008

Driving west on US 90 fifteen miles from Butte, Montana, travelers get their first glimpse and it is dramatic and huge. It dominates the skyline, but not in the same way the Empire State Building towers over New York or the Eiffel Tower stands above Paris. The Washoe Smelter stack sits on a geologic shelf 700 feet above the valley housing the city of Anaconda and Warm Springs Creek, and in front of a mountain as tall as it. This entire landscape is rooted in the Montana Rocky Mountains, just 10 miles from the Continental Divide. The stack, at 585 feet, is the largest free standing masonry structure in the world, 30 feet taller than the Washington Monument, and sits in a view-shed of equally tall and imposing geologic features.

You know it's big because the Rocky Mountains are big. You know it's big because you can clearly see it from more than 10 miles away. Unfortunately you really can't get a sense of exactly how big it is. From even a half-mile away, the stack has still not come into 
its full height. The chief reason is that the stack is the only remaining part of what was once the largest, most complex, and most advanced copper smelter in the world. There are no other buildings or structures left to give it proper scale. In fact, you can't get a real sense of its immense size until you stand right up next to it and look up. (See Figure 6.1)

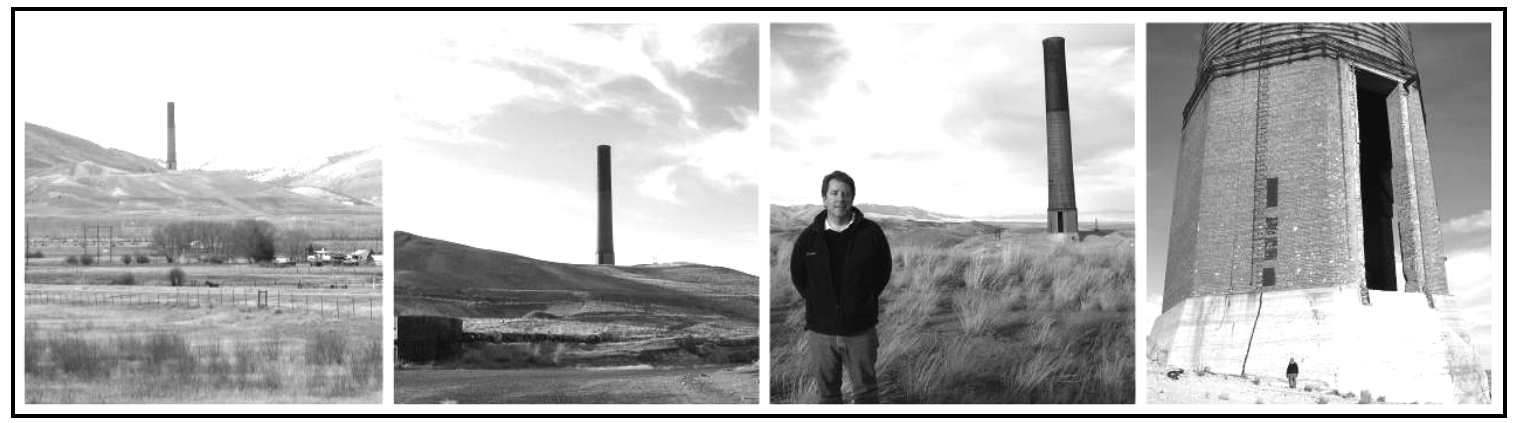

Figure 6.1 Anaconda Smelter Stack, from left to right, approximately six miles, one mile, one-quarter mile, and fifty yards away, November 2008. (Source: Author)

It is remarkable that the stack was saved from demolition. Certainly one of the most complex, heavily photographed, and arguably entertaining parts of many copper smelter reclamation efforts is the demolition of the stack. These structures are often among the tallest free standing structures in any given county and their demolition is a very dramatic event that causes as dramatic a shift in the landscape as their erection. The implosion of the Great Falls (MT) smelter stack, for example, was called slow and defiant and touted as one of the city's most heavily attended events. ${ }^{428}$ Following the announcement of plans to demolish the Washoe stack just a few months after the Great Falls stack came down, a group of dedicated residents formed a committee to save the Anaconda stack, initially as a memorial to the remarkable efforts of the masons who built it, but as the movement gained popular support, the soon-to-be-preserved stack came to

${ }^{428}$ Keith Haugland, "Stubborn Stack Dies Slowly," Great Falls Tribune, September 19, 1982. 
commemorate the town and smelter workers as well, both still reeling from the shock of the smelter's closure and the pending disappearance of the other landmarks of their history threatened by a Superfund mandated clean-up.

Equally peculiar, but for very different reasons, are the remaining slag-wall settling ponds in Butte at the former site of the Butte Reduction Works. This long-lived and innovative early $20^{\text {th }}$ century smelter had immense ponds near its site to store copperrich tailings. Instead of erecting masonry walls or earth dikes, the company used a waste resource it had on hand: slag. To create the walls, smelter workers erected temporary forms for retaining walls, probably of sheet steel, to create boxes roughly $10^{\prime}(1) \times 8^{\prime}(\mathrm{w})$ x 4' (h), and poured molten slag into the forms, let the slag set, then moved the walls to the next section and poured again eventually building up a substantial series of structures, some over $15^{\prime}$ high that impounded an area of approximately 100 acres. Even more interesting, two of the formed walls created a slag-canyon that Silver-Bow creek still flows through. Like the Washoe Smelter, the Butte Reduction Works and all its physical plant have long since been demolished, except for these slag walls. But unlike the smoke stack, whose function is rather intuitive even if its size is not, the slag walls evoke an unknown or little understood historical process until one stumbles upon the interpretative sign one quarter mile off the main street.

Despite the sometimes confusing nature of seemingly random historic features, heritage pervades the Butte-Anaconda region. A fellow researcher in the Butte-Silver Bow archives liked to say that "history is to Butte, what food is to the French." ${ }^{429}$ The

\footnotetext{
${ }^{429}$ Personal communication between author and fellow researcher, November 12, 2009.
} 
ubiquitous symbols of the region's mining history, the gallows frames, are everywhere. ${ }^{430}$ The 13 remaining black steel frames dominate the built environment, and are further emphasized by red cord-lights that outline and illuminate the gallows frames at night. The frames are on license plates, street lights, newspaper banners, phone books, brochures, and countless local advertisements. They decorate city hall. They are modeled in the county courthouse. They are on business cards and in the City-County Seal. They hold up signs, and are stylized in the logo of the Convention and Visitor's Bureau and Mainstreet-Uptown Butte. ${ }^{431}$ Several six-foot (appx.) tall gallows frame models show up on restaurant lawns, abandoned lots, apartment balconies, and even as a mailbox post in one neighborhood. (See Figure 6.2)

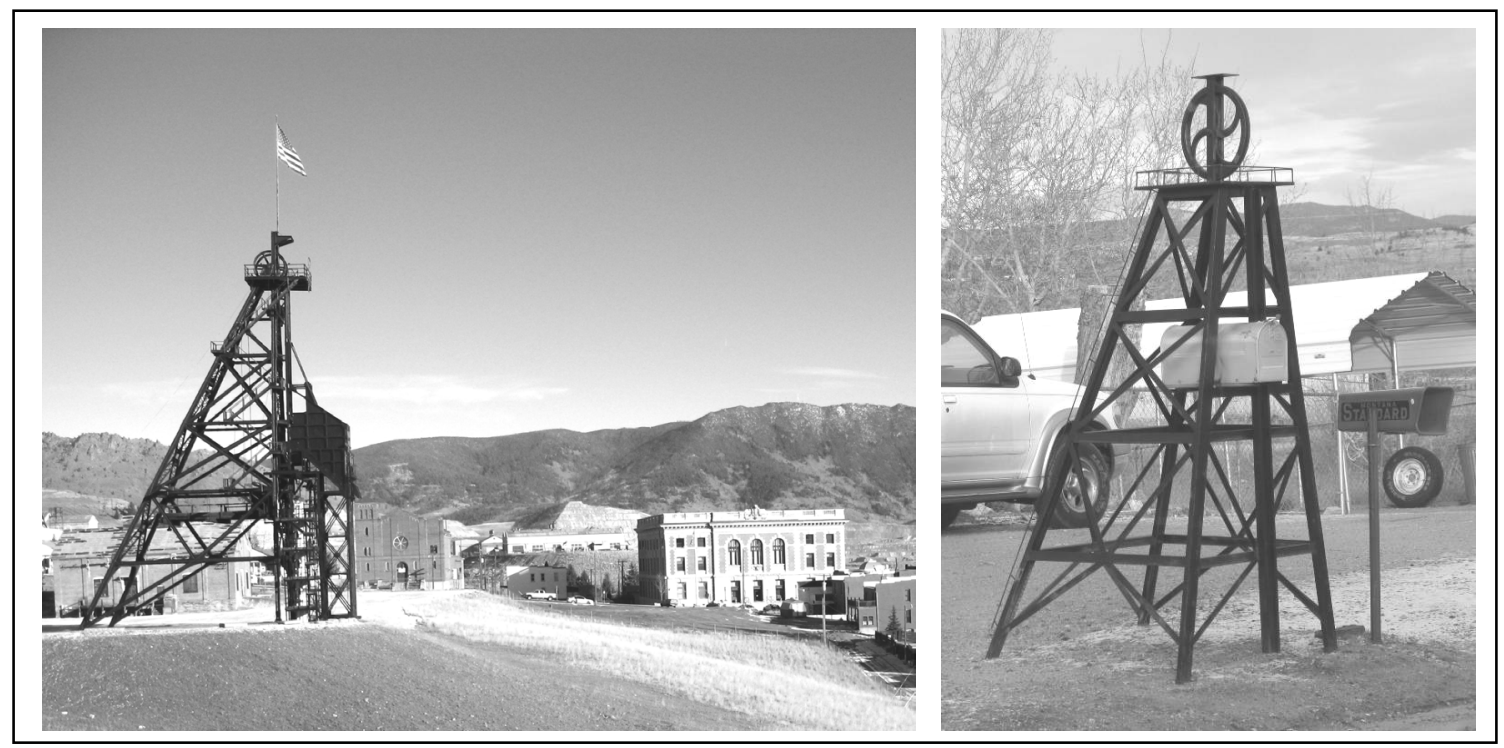

Figure 6.2 Gallows Frames of the Original Mine in Butte (left) and model frame used as a mailbox stand in the Flats (right). (Source: Author)

\footnotetext{
${ }^{430}$ Gallows frames are the colloquial term for the structures at the opening of an underground mine, called head frames in many other parts of the country.

${ }^{431}$ The City of Butte was settled and developed on Butte Hill, called the "richest hill on earth," just below, or in some instances intermixed with the mines. The central business district, commonly referred to as "downtown" in many cites, is called "uptown" in Butte.
} 
Heritage symbols fill Anaconda too, but to a lesser degree. The smaller of the sister-towns, it seems to have had less development and pro-active preservation since the smelter closed and, except for the stack, was demolished. In addition to being visible from ten miles away and in nearly every part of town except the historic cemetery above the county courthouse, reproductions of what locals boast is the tallest freestanding masonry structure in the world show up on car dealers' signs, city web-sites, and advertisements. ${ }^{432}$ "Anaconda Stack" is also the name of the smallest State Park in Montana, founded to take ownership of just the stack site and a small viewing area about a mile away. The name of the City of Anaconda's founder, Marcus Daly, not as maligned as in Butte where references to him only shows up in the name of the Montana Tech coffee/lunch shop as a pun on "daily," turns up in Anaconda motel names, coinlaundry names, and in the name of the local historical society that has had at least four different names since its incorporation several decades ago. ${ }^{433}$

The other and probably second most recognized smelter heritage site in Anaconda is the Jack Nicklaus designed "Old Works Golf Course" built on the location of Anaconda's pre-Washoe smelter site. Although most of the old works structures were removed shortly after the start of the $20^{\text {th }}$ century, Nicklaus incorporated existing

\footnotetext{
432 "Welcome to Anaconda," Community of Anaconda, Montana, http://www.anacondamt.org/, accessed April 2, 2009, and personal observation, November 2008.

${ }^{433}$ A life-size statue of Marcus Daly sculpted by Augustus Saint-Gaudens in 1906 sat in a prominent uptown intersection until a traffic accident forced the removal of the sculpture to the Montana Tech campus. It is preserved and maintained and as such has heritage value, but maybe not as much as it did when it was located in a more prominent location.
} 
foundations and waste piles into the course design, and even filled the sand traps with Washoe smelter slag, now called "sland" by locals. ${ }^{434}$

However, there are not many other popular references to or celebrations of waste or toxicity in the region and only one current visible commercial/iconic reference to the wastewater-filled, former open-pit mine, the Berkeley Pit. The Pit Printers sits on Front Street in Butte, and at some point in the 1990s the "Bookley Pit" bookstore operated. 435 But, like Ducktown, interpretive signs extol the virtues of cleaning up man-made environmental disasters. The Washoe Smelter site, Old Works Golf Course, Butte's gallows frames, and the Reduction Works slag walls are all part of the largest Superfund cleanup in the United States and, at the same time, are part of one of the largest National Historic Landmark Districts in the country. These two competing poles create a rich environment for preservation of what was once the greatest copper mining district among whose notable achievements included significant landscape degradation. (See Figure 6.3)

\section{Shutdown}

The decline of the great Butte-Anaconda district was not linear. The Anaconda Copper Mining Company’s (ACM) Montana mines and smelters experienced their highest production in 1917, but also saw significant peaks in 1929, 1935, and 1943, each within $82-85$ percent of $1917 .^{436}$ Anaconda's rapid buildup in the early $20^{\text {th }}$ century included the 1914

\footnotetext{
434 See: Maney Telefilm video, "Old Works Vision to Reality," ca. 1998.

${ }^{435}$ William Wyckoff, "Postindustrial Butte," Geographical Review 85, no. 4 (1996), 45.

${ }^{436}$ Extrapolated from Janet L. Finn, Tracing the Veins : Of Copper, Culture, and Community from Butte to Chuquicamata (Berkeley: University of California Press, 1998), 247 and Otis E. Young, "The American Copper Frontier, 1640-1893," The Speculator 1, no. 2 (1984), 7.
} 


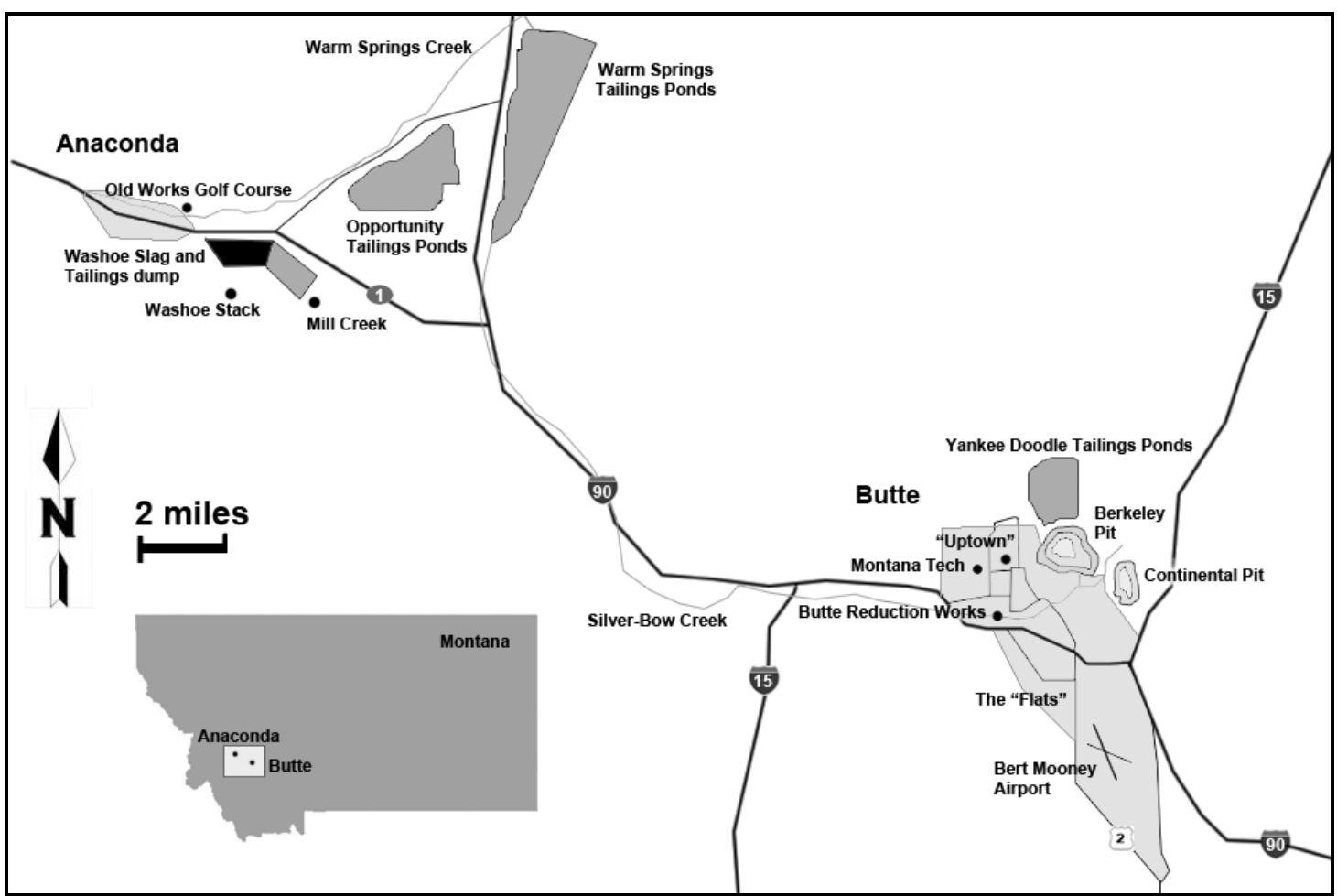

Figure 6.3 Map of Butte-Anaconda showing selected heritage and remediation sites. (Source: Author)

acquisition of International Smelting and Refining and its New Jersey, Utah, Arizona, and Indiana smelters. ${ }^{437}$ In 1915, it became the sole corporate entity of Amalgamated Copper holding company and in 1916, built a zinc plant at Great Falls that by 1920 was the largest in the world, producing over half of the global supply ${ }^{438}$ In 1917 Anaconda built a copper wire and rod mill in Great Falls as it began to vertically integrate more fully. ${ }^{439}$ By 1919 it owned all but two daily newspapers in the state and successfully fought off or favorably negotiated very visible pollution-litigation lawsuits from local

\footnotetext{
${ }^{437}$ Isaac Frederick Marcosson, Copper Heritage; the Story of Revere Copper and Brass Incorporated (New York: Dodd Mead, 1955), 143.

${ }^{438}$ Fredric L. Quivik, "The Anaconda Company Smelters: Great Falls and Anaconda," The Speculator 1, no. 2 (1984), 44.

${ }^{439}$ Ibid., 44.
} 
farmers and the United States Government. ${ }^{440}$ Further, suspicious union-hall bombings and at least one union organizer murder went unprosecuted. In 1922 Anaconda bought American Brass and in 1929 created the Anaconda Wire and Cable Company. ${ }^{441}$ By 1930 , the Anaconda owned nearly $90 \%$ of the copper mining capacity and $100 \%$ of the smelting capacity in Montana, held considerable local and state political power and influence, and had expanded operations into Chile and Mexico.

Despite the growth and expansion of the 1920s and new mining techniques implemented in the 1950s, several historians argue that Montana copper production and the Anaconda Copper Mining Company declined after World War I and never fully recovered. ${ }^{442}$ Although the decline was gradual for several decades, it often appeared worse when compared to the rapidly expanding output of Utah and Arizona. Following earlier copper mining investments in Mexico (1906) and Chile (1917), ACM bought a substantial portion of the Guggenheim's Chile holdings in 1923, including the largest single copper reserve in the world at Chuquicamata. As Chile's mines increasingly buoyed profits, ultimately supplying two-thirds of Anaconda's copper and three-quarters of its income by the 1950s, the once-singularly dominant Butte-Anaconda copper producing region became just a division of a much larger multi-national corporation. In the late 1920s, Kennecott's Bingham, Utah, mine began out-producing Butte, and

\footnotetext{
${ }^{440}$ Mary Elisabeth Curran, "The Contested Terrain of Butte, Montana: Social Landscapes of Risk and Resiliency" (Master's Thesis, University of Montana, 1996), 93. ACM "won" the suits brought by the United States by negotiating some changes to its operations and avoided others by exchanging good land for damaged.

${ }^{441}$ David M. Emmons, "The Price of 'Freedom': Montana in the Late and Post-Anaconda Era," Montana: The Magazine of Western History 44, no. 4 (1994), 68.

${ }^{442}$ Quivik, "The Anaconda Company Smelters: Great Falls and Anaconda," 44; Michael P. Malone, Richard B. Roeder, and William L. Lang, Montana : A History of Two Centuries, Rev. ed. (Seattle: University of Washington Press, 1991), 247; and Wyckoff, "Postindustrial Butte," 478.
} 
Arizona became the single largest copper producing state in the country. ${ }^{443}$ All this happened just 40 years after Montana wrestled the designation of largest copper district in the world from Calumet and Hecla and the rest of the Michigan copper mines.

Despite local fears of a corporate pull out, the Anaconda Company continued to invest, mine, and produce copper in Montana leading to significant World War II output. David Emmons cites combined American and Chilean ACM production figures for 1946, by no means a record year, that included 3.7 million ounces of silver, 30 thousand ounces of gold, 1.47 million pounds molybdenum, 1.55 million pounds of cadmium, 4,883 tons of arsenic, 15.6 million pounds of lead, 1.5 million pounds of zinc, 111,397 tons of manganese, and 742 million pounds of copper, all in the midst of a post-war recession. The Montana component of this production contributed to a 1948 state-wide per capita income sixteen-percent higher than the national average, and likely the second or third highest in the nation. Emmons considers the late 1940s to be Anaconda's and Montana's "last hurrah." 444

On paper, however, Butte-Anaconda produced at a fairly steady pace from the late-1940s through the mid-1970s with peaks and valleys averaging out to a slight increase over the period. ${ }^{445}$ This trend, however, does not reflect significant changes in the mining landscape. In 1947 ACM began the "Greater Butte Project" to recover lowergrade ores from deposits under the city because most of the deep veins were so low in copper content that they could no longer be profitably mined. Up until this time

\footnotetext{
${ }^{443}$ Malone, Roeder, and Lang, Montana : A History of Two Centuries, 249.

${ }^{444}$ Emmons, "The Price of 'Freedom': Montana in the Late and Post-Anaconda Era," 68.

${ }^{445}$ Finn, Tracing the Veins: Of Copper, Culture, and Community from Butte to Chuquicamata, 247.
} 
Anaconda recovered all its copper ore by traditional hard rock stope mining where miners tunneled into ore veins, blasted out most of the copper-bearing rock, then proceeded to next level of the mine and repeated the process sending ore to the concentrators, smelters, then refineries to produce pure copper. The "Greater Butte Project" initially used blockcave mining methods that essentially under-cut ore bodies allowing ores and ceilings to collapse from gravity and then drawing off ores and considerable amounts of other materials from below, substantially reducing labor and mining costs, although entailing a substantial increase in rock and ore haulage before concentration.

Despite claims of 3.5 billion pounds of recoverable copper, plans for a completely interconnected underground system to allow surface-recovery of ores from multiple mines at a single head frame, and a nearly 20 -year extension of underground working, most historians consider the "Greater Butte Project" a bust because it was abandoned after only nine years and never produced at the level expected. ${ }^{446}$ However the success of the block caving plan was measured, the new underground works were quickly overshadowed by an open-pit mining project that recovered even lower-grade ores by means large excavators, dump trucks, and far fewer workers.

The Berkeley Pit began just northeast of uptown Butte in 1955 and quickly ate away at sections of town. Not only did the new mine absorb several historic underground mine sites and above ground smelter locations on Butte hill, but eminent domain or the

\footnotetext{
${ }^{446}$ The ACM block caving project was announced in 1947, yielded its first copper in 1952, and ended in 1961, although other underground mining continued through the late 1960s. See Marcosson, Copper Heritage; the Story of Revere Copper and Brass Incorporated, 274; Brian Shovers et al., Butte \& Anaconda Revisited: An Overview of Early-Day Mining and Smelting in Montana, Special Publication 99 (Butte, Montana: Montana Bureau of Mines and Geology; Montana College of Mineral Science and Technology, 1991), 13 and 26; and Malone, Roeder, and Lang, Montana : A History of Two Centuries, 249.
} 
threat of eminent domain enabled it to consume the neighborhoods of East Butte, Dublin Gulch, Finn Town, Meaderville, and McQueen. ${ }^{447}$ Many of the displaced families and businesses resettled in an area called the Flats, the valley floor south of Butte Hill that had previously housed smelters, ancillary industries, streetcar suburbs, and cemeteries. The Berkeley Pit owed its success largely to the significant quantities of low grade ores that could be mined with relatively few workers, making the poor ore economically profitable. If the late 1940s were the last hurrah for Butte, the opening of the pit and loss of neighborhoods and mining jobs heralded the end of the district and the beginning of even greater changes to the landscape and identity of the region. ${ }^{448}$

As with all other mining districts, as the copper content of the ore diminished, considerably more ore was mined to meet production demands. In addition to greater gangue mined per ton of copper produced, the "Greater Butte Project's" more indiscriminant block-caving methods significantly increased the amount of waste tailings generated by Anaconda, forcing the company to build extensive new settling ponds to keep tailings and dissolved metals from washing into Clark Fork. Operationally, the lowgrade copper ore became too expensive to transport from Butte to the Anaconda concentrating plant, forcing ACM to build a new concentrator in 1964 near the edge of the Berkeley Pit. The erection of this facility effectively closed the concentration

\footnotetext{
${ }^{447}$ Mining the Berkeley Pit 1955-1982, (Butte, Montana: Butte Chamber of Commerce, 2004 (est.)) and Finn, Tracing the Veins : Of Copper, Culture, and Community from Butte to Chuquicamata, 191.

${ }^{448}$ Open-pit mining in Butte continued beyond 2008 buoyed by high, pre-recession Asian demand, albeit on a much smaller scale and with efficiencies requiring far fewer people.
} 
department and tailings ponds in the town of Anaconda as ACM opened new ponds and disposed of waste tailings closer to Butte mining operations. ${ }^{449}$

The population of Silver Bow County (including Butte) peaked in 1920 at 60,000, but dropped by nearly 19,000, or about one third, by 1970. In 1990 the population would drop to half of its 1920 high. Anaconda's Deer Lodge County, whose population peaked in 1960, would not experience significant declines until 1980, but it too would lose nearly half its population by $1990 .^{450}$ Amid declining mineral output and population loss, the company divested itself of its newspapers in 1959 and broke its ties with Montana Power in the 1960s, an organization it had once controlled through common board members.

In 1971, a leftist coup forced out the pro-American, pro-Anaconda government of Chile, and new president Salvador Allende nationalized most foreign-owned mines and smelters in the country. This action spelled the beginning of the end for the Anaconda Copper Mining Company. That same year, ACM declared a net loss of \$357.3 million and went into receivership. ${ }^{451}$ In an effort to trim costs and overhead, the company sold its lumber operations and closed its Anaconda and Great Falls zinc plants. In 1974 it announced it would reduce its workforce by $700-1000$ jobs and the next year laid off 1,500 more workers. In a further effort to remain viable, the company began plans to expand the Berkeley Pit into the uptown area of Butte amid a growing public outcry. Despite a rash of unexplained and unprosecuted fires to both uptown buildings and popular parks, and an effort by Butte's mayor to use the progressive Federal "Model

\footnotetext{
${ }^{449}$ Personal Observation, November 2008.

450 "County Population Census Counts 1900-90," U.S. Census Bureau, http://www.census.gov/population/www/censusdata/cencounts/index.html, accessed April 4, 2009.

${ }^{451}$ Emmons, "The Price of 'Freedom': Montana in the Late and Post-Anaconda Era," 69, and Malone, Roeder, and Lang, Montana : A History of Two Centuries, 250.
} 
Cities" program to fund the relocation of uptown to the Flats (discussed more fully below), the pit only got deeper over the next few years, not wider. By 1977, ACM had eliminated a full one-third of its Montana workforce, closed its last underground mines, ended operations at its Anaconda foundry, and, in a last attempt to continue Butte operations, began mining the East Berkeley Pit, later renamed the Continental Pit to avoid association with the pollution-filled Berkeley Pit just to the west. ${ }^{452}$

These efforts, however, did not save the Anaconda Copper Mining Company. Like Cities Service in the Ducktown district a decade earlier, the Atlantic Richfield Oil Company (ARCO), looking for ways to spend-down some of the considerable cash it earned during the oil crises of the early 1970s, purchased the substantially de-valued holdings and facilities of Anaconda Copper with a promise to invest millions in the state and modernize its mines and smelters. ${ }^{453}$ ARCO's commitments however, were shortlived. In 1980 to the shock and disbelief of Anaconda and Great Falls residents, it closed the company's smelter and refinery operations, citing increased pollution abatement costs, and in 1982 it ended operations at the Berkeley Pit and shut off the pumps, allowing the pit to fill with toxic water.

\section{Epilogue to Butte Mining:}

In 1986, the (Dennis) Washington Construction Company of Missoula, Montana, purchased the mine properties of the Anaconda Copper Mining Company from ARCO, forming Montana Resources, Inc. (MRI) and began mining the Continental Pit for

\footnotetext{
${ }^{452}$ Malone, Roeder, and Lang, Montana : A History of Two Centuries, 250.

${ }^{453}$ Emmons, "The Price of 'Freedom': Montana in the Late and Post-Anaconda Era," 69.
} 
copper and molybdenum on a significantly reduced scale with non-union workers, an unusual arrangement for pro-union Butte, for the first time since $1934{ }^{454}$ It also reopened the 1964 concentrator ACM had built at the Berkeley Pit rim and continued production through at least 2009. More significantly for this dissertation, MRI sold several historic mine sites to a new venture called the Montana Mining Properties, which said it intended to restart underground mining in several of the historic shafts. ${ }^{455}$ In the process of raising additional capital for its operations, however, Montana Mining put several of the historic gallows head frames up for sale for their scrap value. The thought of losing the last few remaining frames may have been the final event that galvanized the community toward preservation. Ultimately none of the head frames offered for sale were purchased for scrap, and all now make up one of the most unique mining heritage landscapes in the country.

\section{Washoe Smelter Closure}

Unlike the gradual end of ACM and later ARCO mining in Butte, the end of copper smelting came very abruptly to the City of Anaconda and its workers on September 29, 1980. At the time, labor and local management were in the midst of strike negotiations, but both groups shared the expectation of a settlement and a quick return to work. Just thee months earlier, the Anaconda Minerals Company (AMC), the name ARCO gave its Montana copper mining division, dedicated a new "state of the art"

\footnotetext{
${ }^{454}$ Eugene C. Tidball, "What Ever Happened to the Anaconda Company?" Montana: The Magazine of Western History 47, no. 2 (1997), 68.

${ }^{455}$ Shovers et al., Butte \& Anaconda Revisited: An Overview of Early-Day Mining and Smelting in Montana, 61.
} 
visitors center at the smelter's main gate, and the company was in the process of upgrading air pollution controls. Further, just three weeks prior to the closure, AMC was publically considering switching back to coal to fire its Anaconda smelters. ${ }^{456}$ In fact, the upper management of the smelter and company-owned railroad were fully expecting to resume operations following the strike and until the morning of September $29^{\text {th }}$ did not know the smelter would close.

Twenty-five years later Mel Stokke, the last general manager of the site, said "the closure was a complete shock, I never thought it would come to pass. Up until the day they told us we were shutting down, I never had a clue." John Greene, general manager of the company-owned Butte, Anaconda, and Pacific Railway, echoed the same sentiment: "We were all pretty damn shocked. It just didn't make any sense to us." Even Roger Williams, regional EPA administrator, expressed surprise and deep concern at the time, that the company proceeded with the closure especially after having had recent discussions with ARCO about alternative solutions to abate sulfur emissions. ${ }^{458}$

Despite a mid-1970s effort to bring the Washoe into compliance with state and federal environmental air pollution laws that included the installation of electric furnaces to melt ores, bag houses to collect dust, and a new acid plant to capture sulfur, the site still fell far short of other regional smelters in terms of emissions control. By the late 1970s, it was the third largest of fourteen western smelters in terms of output, but eleventh in terms of sulfur recovery efficiency, and was cited by the EPA as one of the

\footnotetext{
456 "Anaconda Copper Smelter May Switch to Coal," Chemical Week 123, (1980), 61.

${ }^{457}$ Vera Haffey, "Anacondans Remember Day the Smelter Closed," Montana Standard, September 29, 2005, A1 and A6.

458 "EPA Chief Says Closure a Surprise," The Montana Standard, October 1, 1980.
} 
largest single sources of sulfur dioxide emissions in the country. ${ }^{459}$ Attempts to fix the problem aside, the company claimed increasing difficulty hitting what it considered a “moving target" of federal and state air pollution regulations. ${ }^{460}$ By the late 1970 s, ARCO estimated that it needed $\$ 300-400$ million in upgrades to bring the smelter into full and permanent compliance. ${ }^{461}$ James Marvin, ARCO’s AMC-division president, said, announcing the 1980 closure, "the smelter just can't be retrofitted on any reasonable basis and become cost-competitive with modern smelting operations elsewhere in the world." “Since 1972," reporter Shari Meets paraphrased Marvin's statements made the day after the closure announcement, "the smelter operated on a series of variances granted by the state environmental agencies and, as a responsible company, we do not want to, nor do we intend to, continue making applications for variances from the environmental regulations of this state or union." 462 Citing excess smelting capacity in the world in 1980, most notably in Japan, and the high costs of upgrading, ARCO announced the permanent closure of the strike-idled smelter on September 29, 1980. To lessen the blow, ARCO claimed to be considering the construction of a new, state-of-the-art smelter in Montana or maybe an American port city, but neither came to be as just two years later, it ended all mining in the state.

Skeptics, recounting conflicting factors in the months leading up to the closure, argued ARCO was simply interested in minimizing losses and not protecting its workers or caring about their communities. An EPA study requested by displaced workers under

\footnotetext{
459 "Role of Clean Air Act Requirements in Anaconda Copper Company's Closure of Its Montana Smelter and Refinery," ed. Region 8 U.S. EPA (Denver, Colorado: U.S. EPA, 1981), 5-7.

460 Tidball, "What Ever Happened to the Anaconda Company?" 63.

461 Ibid., 67.

462 Shari Meets, "Anaconda Co. Closes Smelter," Montana Standard, September 30, 1980, 1.
} 
the Clean Air Act showed that the smelter could continue operating under current conditions without any equipment upgrades for eight more years before having to meet new federal air pollution rules and that specific waivers existed for non-ferrous smelters under 1977 revisions to the act. ${ }^{463}$ Further, the EPA concluded that the cost of permanent pollution controls was grossly overestimated and instead of $\$ 300-400$ million dollars, should cost ACM between $\$ 120-160$ million. ${ }^{464}$

More damning claims came from the Montana Eagle, a major independent newspaper, in early December 1981. Journalist Bob McCarthy reported that the closure and layoff of 1500 Anaconda and Great Falls employees came just months before the effective start date of the Resource Conservation and Recovery Act (RCRA) which governed the transportation and disposal of toxic/hazardous wastes. The act, however, contained an exemption for companies that ceased operations before November 19, 1980, prompting the former Anaconda City Commissioner and several state Health Department officials to claim that this date played a significant role in the order to shut down. The acting plant manager, however, denied this claim despite the fact that he too had not been informed of the decision to close until the day of the formal announcement. ${ }^{465}$ Whatever factors led to the decision, the McCarthy article demonstrated that the shock of closure was still festering in late 1981, nearly fifteen months later.

To assuage concerns as much as it could, ARCO pledged support to ease the transition and soften the economic blow. Local officials claimed that the closure would

\footnotetext{
463 "Role of Clean Air Act Requirements in Anaconda Copper Company's Closure of Its Montana Smelter and Refinery," 8.

${ }^{464}$ Ibid., 13.

${ }^{465}$ Bob McCarthy, "Arco's Lethal Legacy," Montana Eagle 1981, 4.
} 
result in \$24 million annual loss to the Anaconda community in wages and an indirect loss of 1.5 non-AMC jobs for every one AMC job lost. Although another \$16 million would be lost each year in Great Falls, the city's greater population and more diverse economy somewhat cushioned its difficult transition away from smelting. ${ }^{466}$ ARCO claimed that it would help place workers in new jobs, pay benefits and severance, and pledged $\$ 5$ million to the city to attract new development. Hopes were pinned in 1981 on a new plastics firm lured with development incentives, but by 1982 the firm had declared bankruptcy and defaulted on the $\$ 900,000$ development loan. Overall, ARCO development funds created only 30 new jobs, while 14 local businesses failed in the two years following the closure. ${ }^{467}$

Ultimately little could be done to soften the blow of closure. In the first few years following the closure people left the region looking for work. The state government promised task forces and attempted to lure new industry, but most efforts did little to stem the rising unemployment and growing economic crisis in the town. Worse for the once proud town, however, was the growing concern for the toxic residue left behind by the smelter and the growing interest by the U.S. EPA in exploring the site under the Comprehensive Environmental Response, Compensation, and Liability Act (CERCLA), or Superfund, the new federal legislation to remediate abandoned hazardous waste sites. Although ARCO pledged to keep cleaning up problems as they arose, in general, the

\footnotetext{
${ }^{466}$ Hugh van Sweringen, "Shutdown Price Tag Will Be \$40 Million Annually," The Montana Standard, September 30, 1980, 1.

${ }^{467}$ Lynda Chavez, "When Arco Left Town," New York Times, July 25, 1982, 15.
} 
company felt it was getting close to the end of its responsibility despite the looming Superfund concerns.

\section{Value Transitions}

Montana's U.S. Senators had better luck combating the declining economy in the Butte-Anaconda region. As early as 1975, Senator Mike Mansfield's support for magnetohydrodynamics (MHD), a high-tech coal conversion technology, brought a development facility to Butte amid significant copper production declines. Mansfield followed this up by sponsoring a bill for the creation of the National Center for Appropriate Technology (NCAT) also to be located in Butte. Signed by President Carter in 1976, NCAT was to apply small-scale and renewable technologies to develop new means to solve the problems common to low income communities. Appropriate technology ideation, Carrol Pursell wrote, came out of a "broad counterculture movement, a reassertion of doubts about the role of technology in American life, and the burgeoning environmental movement." ${ }^{468}$ NCAT, in many ways, stood at the polar extreme ideologically from the Anaconda Copper Mining Company.

Not that a financially declining ACM, or a financially stable ACM for that matter, would be concerned that a few hundred left-leaning professionals moved into the region, but Senator Mansfield nonetheless successfully headquartered the NCAT in Butte. While neither it nor the MHD project was intended as an economic replacement for mining, it was an attempt to change the culture and perception of the region to reflect a more high-

\footnotetext{
${ }^{468}$ Carrol Pursell, "The Rise and Fall of the Appropriate Technology Movement in the United States, 19651985," Technology and culture 34, no. 3 (1993), 630.
} 
tech and diversified future. Both projects contributed hundreds of new high-tech engineering, science, and social-science jobs, but because the region could not fill them locally, they led to the first significant influx of outsiders to Butte since the 1950s. These new residents, discussed below, would play an important role in defining the future identity of the region.

With the end of operations, the district's identity changed as well, emphasizing the finality at the end of its mining era. Like Ducktown, several writers and lawyers now made a point of emphasizing the environmental destruction in Montana caused by ACM mining and smelting operations since the $19^{\text {th }}$ century. Unlike Ducktown, however, it wasn't until copper production ended in the district and the EPA began exploring the area under Federal Clean Air statutes and CERCLA, discussed in the next section, that the negative impact of industrial development, beyond smoke-related problems, became apparent to the public. The significant waste piles surrounding mining and smelting sites, growing scholarly concern about environmental issues, the dramatic loss of Mill Creek housing to contamination in $1987,{ }^{469}$ and, more significantly, the feeling that Montana residents had been left with a huge toxic liability now visible to the entire nation combined to elevate public awareness of the region's environmental dilemma. Montana historian Michael Malone writing in 1985, summed up the growing ethos in the state: The antique Anaconda Smelter shut down in 1980; the landmark Great Falls smokestack was demolished; and the yawning Berkeley Pit now fills slowly with

\footnotetext{
469 The town of Mill Creek sat just a few miles from the Washoe smelter stack directly under the smoke plume. In the mid 1980s, the EPA discovered very high levels of arsenic inside homes and local soils, and CDC tested the town's children who showed significantly elevated levels of arsenic in their blood. Although the first recourse was intended to be a temporary displacement while the EPA supervised remediation, it soon discovered levels too high, and ultimately completely leveled the town.
} 
toxic water, perhaps a fitting symbol of the wrenching death of what has historically been Montana's greatest industry. ${ }^{470}$

David Emmons, writing in 1994, added:

The discovery that the world no longer needed what generations of Montanans had made had a far more chilling effect on the states' collective psyche than any alleged subservience to ACM. ${ }^{471}$

Punctuating the evolving local and national perception of regional defeat and contamination, a large flock of migrating white snow-geese landed in the filling Berkeley Pit in 1995 resulting in 342 deaths. Some of the birds died that same day from pit-acids and arsenic poisoning, leaving hundreds of highly visible white carcasses floating on the pit's surface. Others died within a few days as they tried to leave the area. ${ }^{472}$ Although ARCO and the State of Montana hotly debated the reasons behind the snow-geese deaths, it nonetheless contributed to the declining general perception of the area. In 1993, two years before the snow-geese incident, Travel and Leisure Magazine called Butte, "the ugliest spot in Montana...despite a spirited historic district," and Anaconda, "a sad-sack mining town dominated by a smelter smokestack."473 By 2009, the region's reputation had hit a new bottom culminating in a travel designation as one of the world's "mustmiss" vacation places. ${ }^{474}$

The designation of "must-miss," however, is far from fair. From the mid-1980s through 2008 a well organized and dedicated group of Butte and later Anaconda

\footnotetext{
${ }^{470}$ Michael P. Malone, "The Close of the Copper Century," Montana: The Magazine of Western History 35, no. 2 (1985), 69.

${ }^{471}$ Emmons, "The Price of 'Freedom': Montana in the Late and Post-Anaconda Era," 71.

${ }^{472}$ See: Duncan Adams, "Did Toxic Stew Cook the Goose?," High Country News, December 11, 1995. (www.hen.org/issues/49/1520, accessed August 10, 2009)

${ }^{473}$ Florence Williams, "Butte, Montana, Seeks a New Life," High Country News, November 29, 1993, 2.

${ }^{474}$ Peter Greenberg, Don't Go There!: The Travel Detective's Essential Guide to the Must-Miss Places of the World (Emmaus, Pa.: Rodale, 2009), 33.
} 
professionals and volunteers have been carefully watching the Superfund mandated cleanup. They have skillfully managed the legal framework under CERCLA and NHPA to create not only a safe environment for new economic development, but also a well managed approach to heritage resulting in significant structural preservation and regional industrial/environmental interpretation projects, all funded through the Superfund project.

\section{Early Reaction to Environmental Degradation}

The mining and processing of gold, silver, zinc, and copper ores generated enormous quantities of solid wastes: those wastes were an inherent and unavoidable part of the enterprise. Clogged streams, mounds of overburden, mine dumps, slag heaps, tailings and slime fields and ponds cluttered the landscape of historic Western mining camps and smelting towns. There were occasions when the miners dumped their wastes directly into adjacent streams and rivers; at other times they stored them, often for decades, behind berms and levee walls. Some of this stored waste became trapped in low-lying marshy areas and some if moved through the swamps and was washed into and down streams and rivers. Occasionally spreading out for hundreds of yards on either side of the waterway; some made its way even further downstream. Because they signaled robust and economically healthy mines, these wastes were not initially seen as problematical. While few had anything to say about mining and mineral processing wasteswhether in place or carried by waters - fewer still had any idea of what to do with them. ${ }^{475}$

Much of the early history of land degradation in the Butte-Anaconda district centers around important wastes: smelter smoke, concentrator tailings, and, to a lesser degree, slag. Although tailings are not directly part of the smelting process, they figured significantly in Superfund decisions in both Montana and Michigan copper districts and had clean-up implications at smelter sites in both areas.

\footnotetext{
${ }^{475}$ David M. Emmons, "United States District Court, District of Montana, Butte Division; United States of America v. Atlantic Richfield Company, et al; Expert Report of David Emmons, Ph.D.," (Butte, Montana: 1997), 2.
} 
As discussed in chapter 4 , Anaconda's $19^{\text {th }}$-century sulfur dioxide and arsenicrich smelter smoke killed vegetation and sickened livestock, and the problems only increased as the region's smelters increased capacity in the late $19^{\text {th }}$ and early $20^{\text {th }}$ centuries. The primary recourse for affected parties, however, was through the legal system, suing for property damages or injunctive relief. One of the earliest municipal actions in the country against smelter smoke was the 1890 Butte Smoke Ordinance, which mandated an end to in-town open heap roasting and tall smelter stacks. ${ }^{476}$ The Deer Lodge farmers' and United States Government's lawsuits against Anaconda's Washoe works in the first decade of the $19^{\text {th }}$ century were early significant attempts to formally combat the smoke itself through the court system. None of these efforts, however, ultimately reduced pollution, especially with increasing output leaving ACM free to continue operating nearly unabated for the time.

Early, the company largely settled lawsuits through court actions or monetary payments, or sought a means to minimize damages and potential lawsuits through property purchases, while searching for technical solutions to the smoke problem to abate future legal action. In $1902 \mathrm{ACM}$ paid $\$ 340,000$ to settle claims by farmers and ranchers but, in 1903, built the first large stack and flue system at the Washoe for reducing some smoke emissions. During this period it also conducted its own experiments to determine the affect of smelter smoke, operated ranches and farms under the smoke plume largely to challenge would-be litigants, and acquired smoke (and tailings) easements from some

\footnotetext{
${ }^{476}$ Fred Quivik, "Smoke and Tailings: An Environmental History of Copper Smelting Technologies in Montana 1880-1930" (PhD, University of Pennsylvania, History and Sociology of Science, 1998), 213
} 
property owners. ${ }^{477}$ It also purchased some affected farm land outright to avoid civil penalties and also began purchasing land for tailings storage. The tailings held considerable amounts of copper to be recovered when later technology permitted. Early $20^{\text {th }}$-century land purchases increased Anaconda Smelter holdings in Deer Lodge County from 5,945 acres in 1906 to 7,014 in 1917, and Anaconda's other county land holdings from 3,000 acres in 1906 to 19,139 in $1917 .{ }^{478}$

Following the Department of Justice's 1910 lawsuit against Anaconda, DOJ and ACM established the Smoke Commission in 1911 to monitor pollution and recommend alternative practices to abate future problems. As long as Anaconda consented to the commission's recommendations in good faith, then the Justice Department would not pursue the lawsuit in court. The commission ultimately had a hand in the decision to build the $585^{\prime}$ Anaconda Stack, install Cottrell arsenic precipitators. ${ }^{479}$

By 1920, historian Fred Quivik surmises, the Justice Department may have been satisfied that the Cottrell precipitators recovered $80 \%$ of the arsenic, that the new stack sufficiently disbursed smoke, and that no profitable means for sulfur removal was available in Montana. Further, Anaconda was satisfied that the processes and equipment recommended by the commission ultimately increased profits by recovering saleable by-

\footnotetext{
${ }^{477}$ Marcosson, Copper Heritage; the Story of Revere Copper and Brass Incorporated, 105

${ }^{478}$ Gordon Morris Bakken, "Montana, Anaconda, and the Price of Pollution," The Historian 69, no. 1 (2007), 42-45.

${ }^{479}$ Emmons, "United States District Court, District of Montana, Butte Division; United States of America v. Atlantic Richfield Company, et al; Expert Report of David Emmons, Ph.D.," 8.
} 
products without disrupting smelting operations and, since the Government lawsuit was not formally prosecuted in court, ACM did not have to pay damages. ${ }^{480}$

Although the Justice Department was satisfied with the efforts of Anaconda, the United States Forest Service (USFS) was not. In 1922, it identified 150,000 acres of forest, worth $\$ 1.3$ million in lumber-, land-, and grazing-potential, damaged by smelter smoke. Instead of taking the corporation to court, the USFS proposed a land swap of equal value properties, and Anaconda consented. By 1932, in several separate agreements, the United States and Anaconda exchanged 84,000 damaged acres for 95,000 valuable acres in southwest Montana. Although additional land swaps were negotiated and some later executed with the Forest Service, the Justice Department, feeling there was nothing left for it to do regarding the 1910 lawsuit, ultimately abandoned it in $1933 .^{481}$

The acquisition of Deer Lodge and Silver Bow county lands had one major culminating effect. By 1933, when the Justice Department dropped its lawsuit, ACM had largely settled all of its early pollution issues by buying or trading the agriculture, ranch, and forest lands its smelting operations affected, and, either buying land or purchasing easements on all the other lands it needed to dump its waste. By the 1930s Anaconda operated with a pollution-buffer surrounding its operations that would enable it to operate without interference until the passage of federal regulations to control the transportation and disposal of hazardous wastes starting in the 1970s. (See Figure 6.4)

\footnotetext{
${ }^{480}$ Quivik, "Smoke and Tailings: An Environmental History of Copper Smelting Technologies in Montana 1880-1930," 457-459.

${ }^{481}$ Ibid., 460 and 489.
} 




Figure 6.4 "'E' Smoke gets in their eyes." An end to pollution litigation did not mean an end to smoke problems or even a denial of its existence. This cartoon appeared in The Mining Journal in 1943 reflecting age-old ideas that smoke was a sign of a healthy, robust, and, in this case, patriotic industry. (The Mining Journal, Feb. 15, 1943, 11) 


\section{Origins of the Butte-Anaconda Heritage Movement}

She's battered, and she's beaten,

She's ugly and she's torn,

She's battle-scarred and gutted,

From the Copper she has borne.

Still she is majestic,

As she sits upon her throne

A mile high and beautiful,

To those who call her home.

-George T. Grosse (1957, Quoted in Chavez, 1982)

Reading through the secondary literature on the Butte-Anaconda district, one comes across many poems and short comments reflecting the view that, although their region is regarded as dirty and unkempt, and ACM corrupt, local residents are still proud of their communities and their work. Baum and Knox quoted a retired miner who said, "Them times was tough, but we had no worries about that. Anaconda owned this town, and Anaconda put food on the table." ${ }^{482}$ However, as underground mining slowed considerably in the 1950s and the Berkeley Pit began consuming neighborhoods, the community members remaining after redundant parts of the population left to find work elsewhere, began to think about the glory days when its mines and smelters were some of the largest producers on earth. While the decline of mining in Butte-Anaconda may have initiated heritage directly, the drive to keep mining and expand the Berkeley Pit had a much more powerful influence on the first attempts to document and preserve the region.

\footnotetext{
${ }^{482}$ Dan Baum and Margaret L. Knox, "We Want People Who Have a Problem with Mine Wastes to Think of Butte," Smithsonian 23, no. 8 (1992), 48.
} 
In the same manner as the Michigan District in the 1950s and the Ducktown district in the 1970s, Butte-Anaconda opened a museum at an abandoned mine site and strove to get its significant structures listed in the National Register of Historic Places in the 1960s. The Butte Exchange Club started the museum in 1963, and by 1964 had found a permanent home at the Orphan Girl Mine, donated by Anaconda Copper Mining Company. Between its official opening in 1965 and its $1,000,000^{\text {th }}$ visitor in the $1980 \mathrm{~s}$, the World Mining Museum amassed an eclectic assembly of mining artifacts, many donated by workers or ACM itself, and added a mining hall of fame, a recreated $19^{\text {th- }}$ century wild-West mining town, and above ground, open-air exhibits on mining. By 2008, it had added an underground tour, a memorial garden to fallen mine, smelter, and railroad workers, and a significant photo archive. ${ }^{483}$

While the decline of mining in 1950s and 1960s caused locals to reflect on their past and open a museum, the Berkeley Pit and later the threats of pit expansion caused a much more dire threat to the district than the decline of mining. Where the Michigan and Tennessee districts built museums and lost structures slowly to neglect during the decline and abandonment phases, neither district faced the large-scale destruction of cultural resources until the Superfund period. Butte encountered this earlier. The expansion of the Berkeley Pit destroyed neighborhoods, industrial areas, recreation areas, and churches, and caused citizens to react to start preserving their heritage.

The initial construction of the Pit in the early 1950s and its growth in the ensuing years had clear ramifications on the identity of the district. According to one Relevant

\footnotetext{
483 "History of the Museum," World Museum of Mining, www.miningmuseum.org/historyofwmm.html, accessed April 2, 2009, and personal observation November 2008.
} 
Authority, the growth of the pit in its early years caused local Butte residents to feel trepidation about its expansion, and one local resident, the owner of one of the original "Copper King" mansions, initiated contact with the National Park Service to get portions of Butte listed on National Register. ${ }^{484}$ This effort, although affording little actual protection against pit expansion under eminent domain, resulted in a 1958 survey leading to a National Historic Landmark (NHL) designation for Butte in $1961,{ }^{485}$ covering several uptown blocks and listing at least 31 contributing structures. ${ }^{486}$ The 1961 designation would only be the first step. The original effort would be expanded in 1985 to include a new section formally documenting buildings and mining sites, and the NHL nomination would be significantly enhanced in 2005 to include Anaconda. ${ }^{487}$

Two additional series of events struck at the heart of an economically depressed Butte in the 1970s. First were a series of fires, some resulting from faulty wiring in old buildings, but more troubling were the scores of arsons and fires of unknown origin. Between 1972 and 1975 more than 20 major buildings in the uptown historic district burned. ${ }^{488}$ While several of the arsons went unprosecuted, many locals suspected that at least some of the fires were authorized by ACM preceding the planned Berkeley Pit expansion. Locals recounted stories about friends of friends who earned $\$ 500$ for burning buildings in the 1970s, and others suggested the company used minors as their

\footnotetext{
${ }^{484}$ Conversation with a Relevant Authority (5). Relevant Authority is a term used to protect the identity of individuals providing information during an oral interview. It is a university requirement.

${ }^{485}$ Shovers et al., Butte \& Anaconda Revisited: An Overview of Early-Day Mining and Smelting in Montana, 1.

${ }^{486}$ See: Donald F. Dosch, "National Register of Historic Places Inventory - Nomination Form for Butte Historic District," ed. United States Department of the Interior (Washington, D.C.: National Park Service, 1972).

487 Conversation with a Relevant Authority (5).

${ }^{488}$ Brian Shovers, "Remaking the Wide-Open Town: Butte at the End of the Twentieth Century," Montana: The Magazine of Western History 48, no. 3 (1998), 44.
} 
primary arsonists to allow them to avoid "adult" jail if caught. ${ }^{489}$ At the same time as fires were burning uptown, new commercial developments were being constructed on the Flats including a new shopping mall, airport terminal, restaurants, and housing developments. By 1975 more than 30 businesses had fled the central business district (CBD) for new retail developments in the Flats. ${ }^{490}$ Further, the development of Interstate 90 significantly altered the traffic patterns of the city because it allowed drivers to bypass the older Uptown stores and focus on Flats commercial district. ${ }^{491}$

The city of Butte was shifting away from its historic business district uptown to the sprawling flats south of the hill. While suburbanization was a common feature in most extra-urban growth areas after WWII, Butte had an additional uncommon external pressure on its older surviving neighborhoods: the Pit. By the 1970s, most community leaders seemed resigned to the eventual loss of the uptown area. A map accompanying a revision to the 1960s National Historic Landmark nomination form demonstrated the extent of the expected pit expansion. (See Figure 6.5)

With the decline in mining, an operating museum, and a National Historic Landmark district, the heritage movement had a fairly typical start, very similar to the Ducktown district and many other historic industrial districts in the country. However, the heritage movement in Butte would grow significantly as a result of three more events: the "Butte Forward" plan to relocate the CBD, a significant reduction in funding for the NCAT, and, like the other districts, the advent of Superfund.

\footnotetext{
${ }^{489}$ Personal communication between author and local residents, November 13, 2008.

${ }^{490}$ Shovers, "Remaking the Wide-Open Town: Butte at the End of the Twentieth Century," 44.

${ }^{491}$ Wyckoff, "Postindustrial Butte," 489.
} 
Prompted by the December 1975 letter everyone in town had been expecting for years from ACM detailing the need to expand the Pit, Butte's mayor proposed the "Butte Forward" plan initiated by the Federal Model Cities program. This program granted funds for infrastructure repairs, administrative training, and reorganizational studies under the broad rubric of "urban renewal." Under the 1976 plan, city officials created a public-private development group called Butte Forward, Inc., to plan for and execute

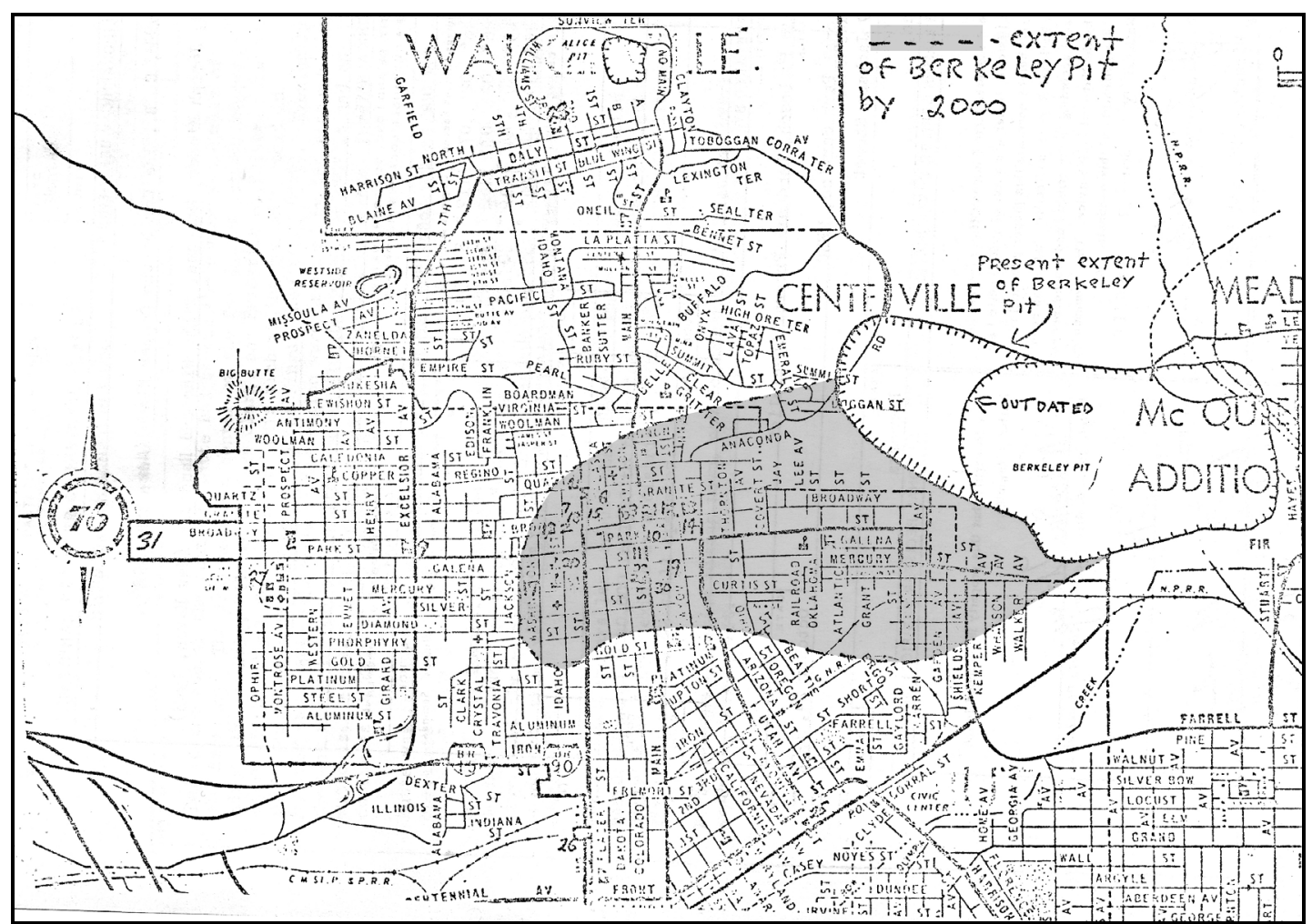

Figure 6.5 Extent of the expected Berkeley Pit expansion from 1970s to 2000 included the primary central business district, courthouse, and several churches, restaurants, bars, and schools. This particular map was used to argue for the creation of the National Historic Landmark district. Ultimately, however, the pit did not expand into the central business district and remained at the size indicated by the "present extent of the Berkeley Pit." (After Dosch (1972). Author shaded area on map to highlight anticipated expansion of the pit through 2000) 
the relocation of the central business district. Later in 1976, the group submitted a $\$ 50$ million dollar proposal to the city with expected contributions of $\$ 11$ million from ACM and $\$ 39$ million from the U.S. Government. Despite a petition effort by uptown merchants calling for a public vote on the matter, and some debate on the actual location of the new business district, the city council voted 8-5 to move ahead as planned, but, because of a procedural matter, tabled the issue and planned to officially reconsider the measure two weeks later. ${ }^{492}$

To the consternation of the Mayor and ACM, the council rejected the plan on the second vote in a move that historian Brian Shovers suggested was possibly the most important decision in the City of Butte's one-hundred year history. Shovers wrote, "In defying relocation [and rejecting the century-long dominance of ACM] Butte not only reaffirmed its historic identity, a persona forged by the rigors and spawned by the culture of underground mining,...but had drawn the line on how much it might sacrifice in the name of a paycheck." Almost immediately Montana Power, which held several seats on the Butte Forward, Inc, board, began purchasing historic buildings and refurbishing them for tax credits while other organizations realized that the city made a significant decision to embrace its historic identity began shifting priorities. ${ }^{493}$

Although many still did not fully embrace heritage as an economic model, several efforts began to funnel money into restoration projects. In 1979 and 1980, the Historic American Engineering Record (HAER), a department of the National Park Service, was invited to Butte under sponsorship of the local government to formally document inactive

\footnotetext{
492 Shovers, "Remaking the Wide-Open Town: Butte at the End of the Twentieth Century," 46-47.

${ }^{493}$ Ibid., 47.
} 
industrial features of the landscape. ${ }^{494}$ At the time, HAER was a part of the Heritage Conservation and Recreation Service of the NPS. While the documentation of historic industrial sites was a paramount component of its mission, the HAER team was also charged with assisting in the redevelopment of blighted areas and in this instance, "analyzing and developing a revitalization strategy for Butte's uptown historic district." ${ }^{495}$ In addition to photographs, drawings, and a written history, the project also proposed the creation of a revitalization agency to manage redevelopment in Butte's historic district. Although parts of Anaconda would be documented during the 1980s, the initial project missed the Washoe Smelter largely because it was a still-active site when the initial documentation began, then demolished before the later documentation efforts began.

Around the same time as the HAER project began, a local resident noticed large dump trucks pulling up to the former ACM office in Butte to dispose of company records. After stopping the destruction of records, he ultimately formed a group that worked with the county executive to establish the Butte-Silver Bow Public Archives in 1981 with $\$ 7.5$ million of public-approved funding. ${ }^{496}$ The archives grew to encompass considerable regional corporate and labor records.

In 1980, Butte consolidated with Silver-Bow County into a single governmental entity and followed the HAER recommendations and created an Urban Revitalization Agency (URA). URAs are basically planning and development organizations designed to

\footnotetext{
${ }^{494}$ Dale Martin and Brian Shovers, "Butte, Montana: An Architectural and Historical Inventory of the National Landmark District," (Butte, Montana: Butte Historical Society, 1986), 1.

495 "Butte, Montana: A Project Report," ed. Heritage Conservation and Recreation Service (Butte, Montana National Park Service, 1980), 7. The HCRS was abolished in 1981 and HAER was transferred to the NPS.

${ }^{496}$ Conversation with a Relevant Authority (6).
} 
use tax increment financing to promote infrastructure and restoration improvement projects, in this case within a specified uptown historic district. ${ }^{497}$ The additional tax collected on the increased value of restored building was then pooled in a fund managed by the URA and reallocated for new restoration and development projects in the historic district. $^{498}$

The growth of heritage interests in the region were further enhanced by setbacks to programs which residents had hoped would offset the loss of mining jobs. In 1980, Ronald Reagan was elected president and set out to reduce the size of the American government. ${ }^{499}$ Reagan slashed budgets and social programs without a strong economic impact and attacked those who, according to Pursell, refused "to embrace technological vanguardism as the finest expression of national virility." 500 Two affected programs were the NCAT office and MHD labs in Butte. Both organizations had brought highly educated and, arguably, activist people to the tough, but fading blue-collar mining town of Butte to work on high tech and politically-progressive programs. When budget cuts hit, the MHD lost several hundred people and NCAT went from over one hundred and twenty people to about ten in a very short time. ${ }^{501}$ Many of those affected stayed in Butte to continue their work and research and would become involved in heritage preservation. Several, for example, formed a corporation reflecting the NCAT mission, Renewable

497 "Minutes of the Meeting, May 26, 2005," ed. Butte-Silver Bow Local Government Study Commission (Butte, Montana: 2005), 9. The URA loaned money for building acquisitions, redevelopment, and other improvements to owners of neglected buildings and houses in the historic district to fund improvements which ultimately raised the value of the building. URA also made facade improvement grants and invested in infrastructure improvements.

${ }^{498}$ Conversation with a Relevant Authority (7).

${ }^{499}$ Pursell, "The Rise and Fall of the Appropriate Technology Movement in the United States, 1965-1985," 630.

${ }^{500}$ Ibid., 636.

${ }^{501}$ Conversation with a Relevant Authority (8) and Conversation with a Relevant Authority (6). 
Technologies, Inc (RTI), a mixed-mission organization that allowed individuals to pursue personal projects, including supporting preservation agendas within the larger superfund project.

Between the 1960s and 1980s, heritage professionals later reflected, Butte and Anaconda's long-term mining residents still hadn't fully embraced heritage as either an expression of identity or potential market for tourists. The long-term residents were often still numb from the closure of the mines and smelters and psychologically shaken by the spate of fires and uncertainty of their town's physical presence. ${ }^{502}$ They felt the heritage movement was driven in many ways by outsiders who, like ARCO, valued the built and cultural landscape differently because it didn't hold the same meanings for them. Further, many of the outsiders came after the demise of the Anaconda Copper Mining Company, the loss of neighborhoods with the construction of the pit, the rash of unexplained fires, and the "Butte Forward" plan.

City of Anaconda residents lagged even further behind those of Butte in heritage concerns despite a significant effort to preserve the Washoe stack and the creation of a local historical society. Whether it was Anaconda's smaller population, the "stillfestering" shock of the smelter closure, or the lack of any new economic development, Anacondans in general seemed to give heritage a lower priority until the Butte movement started thinking of and planning for a larger historic copper production district and included Anaconda smelter, foundry, and transportation sites in the late 1990s and early

\footnotetext{
${ }^{502}$ Shovers, "Remaking the Wide-Open Town: Butte at the End of the Twentieth Century," 47.
} 
$2000 \mathrm{~s} .{ }^{503}$ In fact, it seems that much of the preservation of foundations and waste piles at the old-works golf course came at the insistence of Jack Nicklaus rather than local development officials. ${ }^{504}$

It was ultimately not until the work of the new outsiders began to reshape the district and significant infusions of Superfund-generated money became available for remediation projects that the perception of the "ugly town, set in an ugly notch between two ugly mountains" began to change.

\section{Superfund}

A century of mining and smelting in the Butte-Anaconda district resulted in several significant modifications to the landscape. Not only did it create nearly 3000 miles of underground mine shafts, adits, and tramways, but it dug one of the deepest open pits, built the largest smelter complex in the world in the 1890s and then again in the 1900s, erected the tallest masonry structure in the world, and produced over 30 billion pounds of metals worth over $\$ 22$ billion. ${ }^{505}$ However, in mining and processing the Butte copper lode and extracting significant profits from its sale, industry was ultimately responsible for the landscape changes that resulted from dumping and discharging its wastes, most of it legally, into the local environment. The significant problems associated with the scale of arsenic and sulfur laden smelter smoke and dusts, acidic and

\footnotetext{
${ }^{503}$ Conversation with a Relevant Authority (10).

${ }^{504}$ See: Old Works Vision to Reality, (Butte, Montana: ARCO Environmental Remediation, ca. 1998), VHS video.

${ }^{505}$ Jerrold J. Marcus, "Butte: Richest Hill on Earth and Costliest Mine Superfund Site," Engineering and Mining Journal 201, no. 2 (2000), 33. The 30 billion pounds of metals does not include MRI that produced 1.34 billion pounds through 1999 .
} 
metal-rich waters emanating from tailings deposits and mine drainage, the Berkeley Pit, and significant tailings and slag dumps led, not surprisingly, to serious and extensive problems. From the EPA websites for Silver Bow Creek/Butte Area Superfund Site:

More that 100 years of mining have resulted in the development of over 500 underground mines (with roughly 3,000 miles of underground workings) and 4 open pit mines including the Berkeley Pit with its ancillary tailings ponds, waste dumps, and acid leach pads. Operation of silver mills and copper and zinc concentrators/ smelters in Butte resulted in the production of a variety of mill and smelter wastes including particulates (aerial emissions) and tailings. The long period of mining in Butte left the landscape littered with un-vegetated or sparsely vegetated mine wastes, often containing hazardous concentrations of metals and arsenic. These wastes represent significant sources of environmental contamination to Silver Bow Creek and posed human health and risks to the environment.

Ground water, surface water and soils are contaminated with arsenic and other heavy metals, including copper, zinc, cadmium and lead. Silver Bow Creek and the Clark Fork River contain metals from the cities of Butte to Milltown. The tailings, dispersed along the creek and river, severely limit aquatic life forms and have caused fish kills in the river. Potential health threats include direct contact with and ingestion of contaminated soil, surface water, ground water or inhaling contaminated air. ${ }^{506}$

Similarly for the Anaconda Smelter Superfund site:

The processing facilities at the site were developed to remove copper from ore mined in Butte from about 1884 through 1980. Milling and smelting produced wastes with high concentrations of arsenic, as well as copper, cadmium, lead and zinc. These contaminants pose potential risks to human health, to life in nearby streams, and to plants and animals in adjacent lands over some 300 square miles. In addition to the millions of cubic yards of tailings, furnace slag, flue dust, and square miles of soil contaminated by airborne wastes, millions of gallons of ground water have been polluted from wastes and soils. Arsenic is the primary $\mathrm{COC}$ and drives the remediation. ${ }^{507}$

\footnotetext{
506 "Superfund Program: Silver Bow Creek/Butte Area," U.S. EPA, http://www.epa.gov/region8/superfund/mt/sbcbutte/index.html, accessed April 18, 2009.

507 "Superfund Program: Anaconda Co. Smelter Site," U.S. EPA, http://www.epa.gov/region8/superfund/mt/anaconda/index.html, accessed April 18, 2009.
} 
The scale of mining waste emanating from the Butte-Anaconda region ultimately led to three separate Superfund listings on the National Priorities List, each with multiple individual operable units to coordinate the massive scale of the clean up. ${ }^{508}$ (See Table 6.1) The Silver Bow Creek/Butte Area, officially listed on September 30, 1983, then expanded on July 22, 1987, had 13 individual operable units encompassing Butte mine and smelting sites in the Silver Bow Creek watershed, metals-contaminated residential soils, contaminated mine, pit, and ground water, and the extensive tailings strewn along the length of Silver Bow Creek from Butte down to and including the Warm Springs settling ponds outside of Anaconda. The Anaconda Company Smelter Site, listed on September 30, 1983, included 10 operable units in the Warm Springs Creek watershed relating to three smelting locations and ancillary industries, contaminated soils and house-dusts, and the Opportunity ponds just outside Anaconda. In each of these regions, the chief contaminants were heavy metals that existed in smelter flue dust including significant amounts of arsenic and copper that settled on plants, soils, and inside people's houses, and water contamination with dissolved acids and metals including sulfuric acids, arsenic, cadmium, copper, lead, and zinc that flowed from groundwater into wells and discharged into waterways.

The third Superfund site relating to mining and smelting was the Milltown Reservoir/Clark Fork River area that included 120 miles of the Clark Fork River from Anaconda down to and including the Milltown Reservoir outside Missoula, Montana.

\footnotetext{
${ }^{508}$ Remediation of a fourth regional Superfund site, the Montana Pole and Treating Plant Site was also funded by ARCO although its contamination came primarily from the treatment of wood poles for bridge and road construction, and utility needs from the 1940s-1980s not directly from mining activities.
} 
Table 6.1 List of Superfund Operable Units in Butte and Anaconda

\begin{tabular}{|c|c|c|}
\hline \multicolumn{3}{|c|}{$\begin{array}{l}\text { Silver Bow Creek/Butte Operable } \\
\text { Units }\end{array}$} \\
\hline 1 & $\begin{array}{l}\text { Streamside } \\
\text { Tailings }\end{array}$ & Remedial \\
\hline 2 & Area One & \\
\hline 3 & $\begin{array}{l}\text { Butte Mine } \\
\text { Flooding }\end{array}$ & Remedial \\
\hline 4 & $\begin{array}{l}\text { Warm Springs } \\
\text { Pond }\end{array}$ & Remedial \\
\hline 5 & $\begin{array}{l}\text { Reduction Works } \\
\text { Tailings }\end{array}$ & Removal \\
\hline 6 & Travona Mine & Removal \\
\hline 7 & Rocker & Remedial \\
\hline 8 & Butte Priority Soils & Remedial \\
\hline 9 & $\begin{array}{l}\text { Active Mining and } \\
\text { Milling }\end{array}$ & Remedial \\
\hline $\begin{array}{l}1 \\
0\end{array}$ & Residential Soils & Removal \\
\hline $\begin{array}{l}1 \\
1\end{array}$ & Lower Area One & Removal \\
\hline $\begin{array}{l}1 \\
2 \\
\end{array}$ & $\begin{array}{l}\text { Warm Spring } \\
\text { Ponds Inactive }\end{array}$ & Remedial \\
\hline $\begin{array}{l}1 \\
3\end{array}$ & West Side Soils & Remedial \\
\hline
\end{tabular}

\begin{tabular}{|l|l|l||}
\hline \multicolumn{3}{|l|}{ Anaconda Co. Smelter Site Operable } \\
Units
\end{tabular}

Removal actions are intended for the immediate removal of direct threats to human health and the environment while remedial actions are intended to be long-term, permanent solutions to contamination.

This site was broken into just two operable units, the Milltown Reservoir, which entailed 2.2 million cubic yards of impounded contaminated tailings, and the Clark Fork River's entire length which was strewn with tailings that did not wash all the way down to

\footnotetext{
509 See: "Second Five-Year Review Report for Silver Bow Creek/Butte Area Superfund Site," ed. Region 8 U.S. EPA (Helena, Montana: CDM, 2005).

${ }^{510}$ See: "Third Five-Year Review Report for Anaconda Company Smelter Site Anaconda, Deer Lodge County, Montana," ed. Region 8 U.S. EPA (Helena, Montana: U.S. EPA, Region 8, 2005).
} 
Milltown. Here, too, the primary concern was heavy metals that precipitated out of water and contaminated Clark Fork riparian and impounded Milltown soils. In both operable units, the primary solution was the removal of contaminated soils and tailings and depositing them in the still open Opportunity Ponds in Anaconda.

Unlike Occidental Petroleum in Ducktown, ARCO accepted the initial listing but like Occidental resisted active participation for a decade claiming that the oil company didn't pollute the region directly. ${ }^{511}$ Further, ARCO contended, as the State of Montana and EPA sought additional penalties, that the state and federal governments were also potentially responsible parties because they both encouraged mining for regional and national gain and did not create or enforce stricter pollution legislation. ARCO eventually hired its own historians to prove it in court. ${ }^{512}$ That argument, however, was largely lost as early as 1983, when ARCO consented to pay for initial remediation projects.

Court challenges continued, nonetheless, through the 1990s and into the 2000s, especially after both the state and federal governments sought to recover their costs and impose civil penalties for reparations and community projects. ARCO responded to the new charges and filed suits against both the U.S. Government and the State of Montana to recover its response costs, contributions, and to receive "contractual indemnity, equitable indemnification, and declaratory relief' citing the government's conspiracy to

\footnotetext{
${ }^{511}$ Conversation with a Relevant Authority (9).

512 Emmons, "United States District Court, District of Montana, Butte Division; United States of America v. Atlantic Richfield Company, et al; Expert Report of David Emmons, Ph.D.,", 96, and "State of Montana v. Atlantic Richfield Company, Consent Decree," ed. Helena Division United States District Court for the District of Montana (Helena, Montana: United States District Court, 1998).
} 
develop and promote mining in the western United States. ${ }^{513}$ Ultimately, however, with a series of negotiated consent decrees from 1998 to 2008, ARCO agreed to pay additional civil penalties, albeit less than originally sought by the lawsuits, and to cover governmental cost and oversight expenses. ${ }^{514}$

Needless to say, the entire remediation project emanating from mining and smelting in the Butte-Anaconda region led to significant Superfund clean-up costs and, in terms of geography, became the largest executed in the country. By 2008, ARCO had agreed to pay the State of Montana \$230 million for natural resource damages to Silver Bow Creek, ${ }^{515} \$ 168$ million for damages associated with the Clark Fork River and other sites, and nearly $\$ 14$ million to the U.S. Government for EPA costs and to settle damage claims made by the National Park Service and Bureau of Land Management. ${ }^{516}$ Additional costs included an estimated of \$316 million to remove sediments from the Milltown Reservoir and even more for other clean ups, community development projects, EPA and state fees, and long-term waste monitoring and remediation projects for various

\footnotetext{
${ }^{513}$ Emmons, "United States District Court, District of Montana, Butte Division; United States of America v. Atlantic Richfield Company, et al; Expert Report of David Emmons, Ph.D.," 53.

${ }^{514}$ United States District Court for Montana, "United States v. Atlantic Richfield Company, State of Montana v. Atlantic Richfield Company, Streamside Tailings Operable Unit and Federal and Tribal Natural Resource Damages Consent Decree," (Helena, Mont.: United States District Court for Montana, 1998) 2, and "Summary of 2008 Settlement of Clark Fork River Remediation and Natural Resources Damages Claims and Related Restoration Plans," ed. Montana Department of Justice (Helena, Montana: Natural Resource Damage Program, 2008), 1-3.

515 "Upper Clark Fork River Basin Restoration Plan Procedures and Criteria," ed. Natural Resource Damage Program State of Montana (Helena, Mont.: State of Montana, 2000), 7.

516 "Summary of 2008 Settlement of Clark Fork River Remediation and Natural Resources Damages Claims and Related Restoration Plans," 1.
} 
sites in the districts. ${ }^{517}$ As early as 2002, ARCO expected its total bill for clean up in Montana would exceed $\$ 1$ billion dollars. ${ }^{518}$

Although the Environmental Protection Agency vigorously pursued ARCO under CERCLA in pursuit of its mission to protect human health and the environment, it was less concerned with ancillary requirements of CERCLA, such as abiding by the Applicable or Relevant and Appropriate Requirements (ARARs) as required under section 121(d). Almost from the beginning, the EPA eschewed its responsibilities to fully consider impacts to cultural resources eligible for inclusion on the National Register as required under Sections 106 and 110 of the NHPA. According to a Relevant Authority directly affiliated with clean-up monitoring for the U.S. government, the EPA met only the minimum necessary requirements of Sections 106 and 110 as it interpreted them, and simply took photographs of buildings in 1987 it thought might be impacted. ${ }^{519}$ Jerrold Marcus, writing in the Engineering and Mining Journal, stated the EPA only had two strategic goals: remediate the site and allocate as much of the costs as possible to the potentially responsible parties. Further, EPA officials understood that as a lead agency, it would be "severely criticized" for its decisions by other stakeholders no matter what it did. ${ }^{520}$ Heritage professionals fell into this latter group.

Mark Reavis, former Butte-Silver Bow County preservation officer, recounted that he had to fight the EPA and ARCO to get them to comply with NHPA and retain the

\footnotetext{
${ }^{517}$ Sherry Devlin, "Arco Recommends Leaving Milltown Sediment," Missoulian, November 6, 2001.

${ }^{518}$ Karen Dorn Steele, "Superfund Revived Butte," Spokesman Review, July 28, 2002.

${ }^{519}$ Conversation with a Relevant Authority (9).

${ }^{520}$ Marcus, "Butte: Richest Hill on Earth and Costliest Mine Superfund Site," 41-42.
} 
region's significant historic character. ${ }^{521} \mathrm{He}$ later argued that, "Odd as it sounds, those dumps are historic resources. The preservation community here is worried that we're going to lose, bury, and cover-up all signs of mining. Butte should be a monument to a social decision: the quest for minerals. I'm trying to preserve. They're trying to clean up." ${ }^{522}$ Fredric Quivik, who came to Butte to work for NCAT in 1977, wrote in 2001, "the EPA...often pursued its mandate to remediate hazardous materials with a singlemindedness that has not recognized other national priorities, such as the preservation and interpretation of important cultural resources." ${ }^{, 523}$ "Local [EPA] administrators seemed to see the historic copper industry as the enemy, and they saw the only design alternative for remediation to be the obliteration [of] any historic features that happened to be in the way of the clean-up and to cover those areas with newly planted grass." 524 A Relevant Authority affiliated with preservation management in Anaconda-Deer Lodge County acknowledged that Superfund benefited the health of the community but noted that it could be detrimental to historic preservation. Further, this authority cited instances where EPA manipulated Sections 106 and 110, claiming that sites it didn't want to remediate were historic while other sites it wanted to clean were not. ${ }^{525}$

The Butte-Anaconda district, with the largest superfund sites and one of the largest National Historic Landmarks, highlights the inherent conflict between remediation and preservation. Unlike Ducktown, where the heritage decisions were largely left in the

\footnotetext{
${ }^{521}$ Curran, "The Contested Terrain of Butte, Montana: Social Landscapes of Risk and Resiliency," 269.

522 Jeffery St. Clair, "Something About Butte," in Red State Rebels: Tales of Grassroots Resistance in the Heartland ed. Joshua Frank and Jeffery St. Clair (Oakland, California: AK Press, 2008), 93.

${ }^{523}$ Fredric L. Quivik, "Integrating the Preservation of Cultural Resources with Remediation of Hazardous Materials: An Assessment of Superfund's Record," The Public Historian 23, no. 2 (2001), 48.

${ }^{524}$ Ibid., 51.

${ }^{525}$ Conversation with a Relevant Authority (10).
} 
hands of the remediaters, the Butte-Anaconda district with combative new residents and a strong Montana SHPO and heritage community, ultimately established procedures and negotiated heritage preservation with both the key national heritage organizations and the EPA and ARCO, although during the planning process many sites, like the Washoe smelter, were lost.

\section{Superfund-generated heritage}

In Butte-Anaconda, the clout of heritage preservation advocates grew slowly between the mid-1980s and 2005, and included the creation of county-level preservation officers to oversee heritage management plans. (See Table 6.2 for a summary of dates.) While Superfund/ARCO funded or contributed to many of these plans, the genesis of these efforts were often local reactions to the potential loss of cultural fabric from cleanup activity that had mostly been driven by the new, proactive outsiders captivated by the region's rich heritage, but not "affected" as much by its decline. According to a Relevant Authority, the URA gave birth to the first comprehensive preservation ordinance in the region. ${ }^{526}$ Although the National Historic Landmarks (NHL) office established an architectural district in 1961 and Butte established physical boundaries for tax increment funded redevelopment in 1980, the URA created a new historic overlay zoning district in 1985, twice the size of the earlier urban revitalization area to promote the preservation of historic sites, structures, and buildings by "addressing preservation issues at the local level and integrating them into the planning and decision

\footnotetext{
${ }^{526}$ Conversation with a Relevant Authority (7).
} 
Table 6.2 Timeline of Preservation and Remediation Events in Montana

\begin{tabular}{||l|l|l||}
\hline Dates & Event & Location \\
\hline 1961 & First Butte district NHL listing & Butte \\
\hline 1965 & Mining Museum Opens & Butte \\
\hline 1967 & Underground mining ends & Butte \\
\hline 1971 & Chile nationalizes mines & Butte \\
\hline 1975 & MHD lab opens in Butte & Butte \\
\hline 1976 & NCAT office opens in Butte & Butte \\
\hline 1976 & Threat of Butte CBD relocation & Butte \\
\hline 1977 & ARCO buys ACM & Butte \\
\hline 1979 & HAER documentation & Butte \\
\hline 1980 & URA begins & Butte \\
\hline 1980 & Washoe Smelter closes & Anaconda \\
\hline 1981 & Butte Silver Bow Archives begins & Butte \\
\hline 1981 & MHD and NCAT budgets slashed & Butte \\
\hline $1982-1986$ & Washoe Smelter Demolition & Anaconda \\
\hline 1983 & Superfund National Priorities List & Butte-Anaconda \\
\hline 1985 & First Butte NHL expansion & Butte \\
\hline 1985 & Washoe Smelter Stack saved & Anaconda \\
\hline 1985 & Butte-Anac. Historic Park Master Plan & Butte-Anaconda \\
\hline 1988 & General Work Plan for Anaconda cleanup & Anaconda \\
\hline 1990 & RI/FS for Anaconda & Anaconda \\
\hline 1993 & Regional Historic Park Plan & Butte-Anaconda \\
\hline 1997 & Old Works Golf Course opens & Anaconda \\
\hline 2005 & Second NHL expansion, includes Anac. & Butte-Anaconda \\
\hline 2008 & Butte Reduction Works slag walls saved & Butte \\
\hline \hline
\end{tabular}


making process." The ordinances' specific goals were to "enhance the visual character... encourage maintenance of the present housing stock...promote [cultural] tourism... enhance property values...foster public appreciation of and civic pride in the beauty of the community and accomplishments of the past... and to safeguard the heritage of the community." 527

More significantly, the new ordinance specifically included the existing thirteen head frames and defined historic buildings to include "appurtenant mining structures." It also created a historic preservation commission to administer the preservation ordinance and a historic preservation officer to enforce codes that required a review and permit process to move, remove, or demolish historic structures, and created appeals, enforcement, and penalty policies for violations. Before defining the boundaries of the new district, however, the new ordinance required a new survey to identify structures.

The years from 1981 to 1986 witnessed several surveys, documentation efforts, and planning processes to catalog historically significant structures in Butte, expand the original National Historic Landmark district to include industrial sites, consider sites in Anaconda, and begin planning for an eventual National Historical Park dedicated to American copper. Following the Historic American Engineering Record documentation project in 1979, the Butte Historical Society began a five-year project to survey all historic resources in the historic district. ${ }^{529}$ By 1985 the Butte Historical Society, with additional financial support from ARCO, the State of Montana, community development

\footnotetext{
527"Council Bill No. 238 ("1985 Preservation Ordinance")," in Ordinance 238, ed. Butte-Silver Bow Montana (Butte, Montana: 1985), 8.

528 Ibid., 7.

${ }^{529}$ Martin and Shovers, "Butte, Montana: An Architectural and Historical Inventory of the National Landmark District," 1.
} 
grants, and a host of additional sources, funded an RTI planning study of the architectural and industrial heritage of the Butte-Anaconda corridor that ultimately created a context for preservation. Not only did these studies put the entire mining/smelting district into a single historic context for the first time, but ultimately served to provide reference points for restoration projects and long-term planning efforts. ${ }^{530}$

Two significant planning documents came from this effort. First, with the realization that so much industrial heritage still existed, the original 1961 National Historic Landmark District was expanded to include mining sites on Butte hill. More importantly, the study generated the first comprehensive heritage planning document for the combined mining and smelting districts. The Butte-Anaconda Historical Park System Master Plan was written by RTI in 1985 and published by the Butte Historical Society with funds from Anaconda Minerals Company, the National Trust for Historic Preservation, the Montana State Historic Preservation Office, Tri-County Historical Society (Anaconda), Anacondans to Preserve the Stack, and Butte the Uptown Association. The plan:

grew out of the perceived need to develop a comprehensive and coordinated plan of action to protect and interpret the historic features of Butte and Anaconda. Many of these nationally significant mining and smelting sites are threatened by demolition, vandalism, natural deterioration, and proposed reclamation...This study [is] a first step in combating these problems while integrating historic preservation and environmental reclamation. ${ }^{531}$

\footnotetext{
${ }^{530}$ See: Ibid. and Mark Fiege, Fredric L. Quivik, and Brian Shovers, "Industrial Heritage of Butte and Anaconda: An Analysis of the Historical Significance of the Surviving Physical Features of the Anaconda Copper Mining Company," (Butte, Montana: Butte Historical Society, 1985).

531 "The Butte-Anaconda Historical Park System Master Plan," ed. Renewable Technologies Inc. (Butte, Mont: Butte Historical Society, 1985), i.
} 
The plan stemmed partially from the many requests for support of preservation and community projects received by the Anaconda Mineral Company and its desire for a coordinated approach to site management. The master plan provided historic background to the region, several interpretive themes for future heritage exhibits, expected community contributions and tourism benefits, and a phased approach to implementation. While the National Park Service ultimately rejected the idea of a National Historical Park in Butte-Anaconda, citing a new copper-industry themed national park in Michigan's mining district, regional planners in Montana hoped to create at a minimum a partnership-based National Heritage Area. ${ }^{532}$

While the regional park plan was being worked on, the EPA was in the midst of evaluating the region under CERCLA and determining the best course of action for remediation. The park plan recognized the significant potential impact to historic resources from remediation and that planning would require "creative thinking and innovative reclamation" to successfully meet both goals of historic preservation and cleanup activities. ${ }^{533}$ At the same time as significant planning was being undertaken, the Butte Historical Society began a short-lived journal named the Speculator after one of the local mines. Although it didn't survive beyond three volumes, in its short life the Speculator collected a wealth of research on the history and heritage of the mines, people, and region.

CERCLA-mandated remediation projects were well under way by the early 1990s, when the heritage community and the state began raising serious issues based on

\footnotetext{
${ }^{532}$ Conversation with a Relevant Authority (5).

533 "The Butte-Anaconda Historical Park System Master Plan," 56.
} 
Sections 106 and 110 of the National Historic Preservation Act. In most Section 106 or 110 proceedings, the State Historic Preservation Officer monitors and rules on issues of National Register eligibility and required mitigation of impacts, often on a case by case basis. However, the extent of this particular Superfund project and the extensive potential for impacts required a more formally planned approach. In 1992 and again in 1994, the Environmental Protection Agency, the Advisory Council on Historic Preservation, the Montana State Historic Preservation Office, the Montana Department of Health and Environment, the counties of Butte/Silver Bow and Anaconda/Deer Lodge, Walkerville, and ARCO entered into a programmatic agreement regarding the creation of a regional historic preservation plan (1992) and an implementation strategy for the completed plan (1994). Recognizing the "substantial potential for the loss of historic resources... under CERCLA" and the importance of compliance with NHPA, the parties agreed to create a comprehensive preservation plan to consider potential impacts before they occurred and decide which significant structures would require what type of mitigation before impact occurred while recognizing the potential for "undiscovered" resources and mitigation procedures. ${ }^{534}$

The Regional Historic Preservation Plan (RHPP), developed by the 27-member RHPP Joint Committee and completed in 1993, was the culmination of ten years of heritage planning in the district. It brought together the work of all the previous surveys

\footnotetext{
534 "Programmatic Agreement among the Environmental Protection Agency Region VIII Montana Office, the Advisory Council on Historic Preservation, the Montana State Historic Preservation Office, Montana Department of Health and Environmental Sciences, Local Governments of Butte/Silver Bow and Anaconda/Deer Lodge, Walkerville, and Arco Regarding Development of and Implementation of the Upper Clark Fork River Basin Regional Historic Preservation Plan," ed. Environmental Protection Agency (Butte, Montana: 1992),1.
} 
and plans and included sections on preservation and remediation issues, interpretive themes and related sites, revitalization, management, and planning. It also outlined the goals of preservation articulated by CERCLA and included relevant legal documents describing Sections 106 and 110 of the NHPA, earlier programmatic agreements, and studies. $^{535}$

Lastly, in 2005, the Secretary of the Interior substantially expanded the National Historic Landmark district beyond its 1961 focus on Butte. The district grew from the original 31 individual contributing structures listed in the 1972 inventory to over $5000 .^{536}$ After successive expansions in Butte, the new NHL district designation, organized under considerations expressed in the National Park Service labor theme study, included substantial new commercial, residential, and, industrial sites in Butte and Anaconda, and the railroad corridor between the two. This document, with the studies and plans executed in the 1990s, completed the transformation of two distinct cities into one single, large heritage planning district. While no single national or state historic park was established to interpret the region as a whole, both the RHPP and NHL district designation provided a broad coordinated understanding and approach to heritage management in the region.

As the planning process progressed, the communities of Butte and Anaconda both began backing heritage projects more enthusiastically. New organizations such as Butte

\footnotetext{
${ }^{535}$ See: "Regional Historic Preservation Plan: Butte-Anaconda Corridor," (Butte, Montana: Regional Historic Preservation Plan Joint Committee, 1993).

${ }^{536}$ See: Dosch, "National Register of Historic Places Inventory - Nomination Form for Butte Historic District," and "National Register of Historic Places Registration Form: Butte-Anaconda Historic DistrictNational Historic Landmark Nomination," ed. Department of the Interior (Butte, Montana: National Park Service, 2005).
} 
Citizens for Preservation and Restoration (CPR) and the Restoration Alliance worked to support the efforts of the existing Certified Local Government and Main Street preservation and development programs. ${ }^{537}$

Despite the growing strength of the local heritage movement, the national perception of Butte-Anaconda did not evolve equally. Becoming the second largest National Historic Landmark district in the United States was no match for the stigma of being the largest superfund site in the nation. From the 1990s to 2009, the national media focused on the environmental devastation. Articles on Butte-Anaconda appeared with titles like, "We Want People who have a problem with Mine Wastes, to think of Butte" (1992), "Pennies from Hell” (1996), "Butte America: Poisoned, Ruined, and SelfCannibalized" (1997), "Butte Breaks Ground to Mop up a World-Class Mess" (1998), "Richest Hill on Earth and Costliest Mine Superfund Site" (2000), "Montanans Weigh Options on a Toxic Legacy" (2001), and "In a Town Called Opportunity, Distress over a Dump." These contributed to existing, and previously cited, designations of ugliest spot in Montana (1993) and one of the world's must-miss vacation spots (2009). Occasionally some glimmer of hope that all had not been destroyed by pollution appeared in articles like "In its own decay, Butte Sees a National Treasure (1997) and "Town Pins Hopes on Superfund Site" (1997). ${ }^{538}$

\footnotetext{
${ }^{537}$ Butte Citizens for Preservation and Restoration (CPR) and the Butte Restoration Alliance are both private non-profit member organizations. CPR provides grants, education, workshops, and coordination with other public and private groups to promote preservation in the National Historic Landmark District. (www.buttecpr.org, accessed May 3, 2009) The Restoration Alliance provides expert advice on spending and development to promote safety, neighborhood enhancement, historical and cultural preservation, and recreation opportunities. (www.butterestorationalliance.org, accessed May 3, 2009)

${ }^{538}$ See: Baum and Knox (1992), Dobbs (1996), Baum (1997), Robbins (1998), Marcus (2000), Lurgio (2001), Robbins (2005), St. Clair (2008), Egan (1997), and Robbins (1997).
} 


\section{Smelter heritage}

Despite the drive of the Superfund clean up, three significant elements of the region's smelting landscape remained in 2009: the Butte Reduction Works slag walls, the Washoe Stack, and foundations and waste piles of the Anaconda Old Works. All three of these sites were slated for demolition at some point in the Superfund planning process, but regional heritage advocates organized to save them. The rest of the Washoe smelter site, however, was not so lucky and was demolished just as the Superfund process and more organized heritage planning began in Montana.

The Butte Reduction works operated from 1885-1910 at the base of Butte Hill along Silver Bow Creek south of town. Early in its operations, like other smelters in the district, it realized existing concentrating technology left considerable copper in the tailings and was concerned about potential lawsuits from downstream land owners so it stockpiled its tailings. Unlike the earthen berms of the Anaconda Company, the Butte Reduction Works built waste-slag retaining walls to impound its tailings and keep them from washing down Silver Bow Creek during spring floods. Although the smelter itself was largely dismantled by WWII, much of the tailings and slag retaining walls remained at the start of the Superfund cleanup. (See Figure 6.6)

EPA assigned the two parts of the site to Operable Unit Lower Area One and Operable Unit Reduction Works Tailings, and in 1993 began removing 1.2 million cubic yards of metals- and arsenic-contaminated tailings and other hazardous wastes. The materials were disposed of in a nearby storage area where they were capped with clean soils and covered with an impermeable membrane to prevent water from leaching acids 


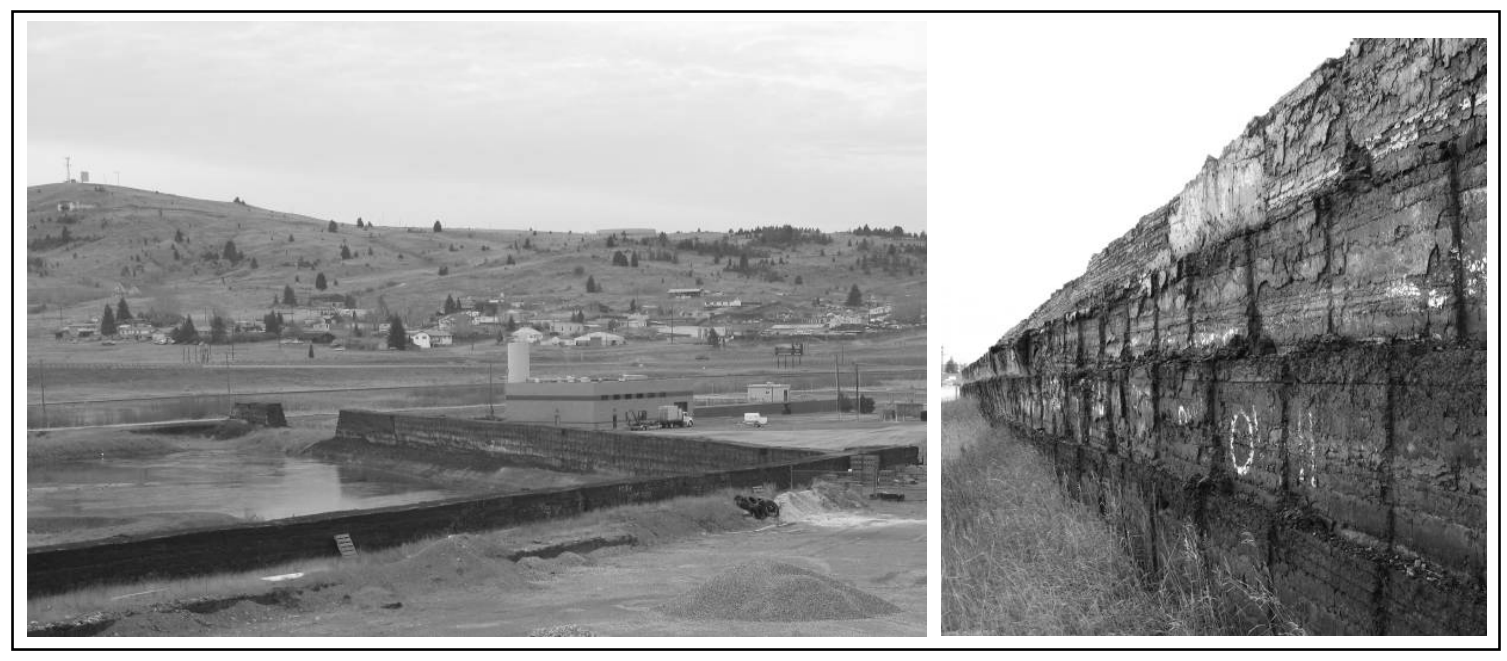

Figure 6.6 Slag walls of the Butte Reduction Works, 2008, showing former enclosed tailings ponds and close up of unique slag wall construction technique. (Source: Author)

and heavy metals. The second phase of remediation involved restoring of the natural flow of Silver Bow Creek, creating a buffer wetlands area, installing a groundwater treatment facility, and constructing an interpretive trail through the site. ${ }^{539}$ According to a Relevant Authority, however, the initial plan also called for the removal of the slag walls that ran throughout the site. This would have lowered the cost and complexity of the remediation project and contributed to a more "natural" looking area, both high priorities for the EPA. ${ }^{540}$

However, the 1985 park plan called the slag walls at the site "the best preserved remnant of [the Butte smelting] component of the local mining history," ${ }^{, 51}$ and cited its very high integrity and interpretive potential with minimal safety concerns. It also called

\footnotetext{
${ }^{539}$ A Story of Rebirth (Butte, Montana: ARCO, c. 2004).

${ }^{540}$ Conversation with a Relevant Authority (9).

541 "The Butte-Anaconda Historical Park System Master Plan," 74.
} 
for an interpreted, self-guided tour through the site. ${ }^{542}$ The 1993 Regional Historic Preservation Master Plan called the slag walls the primary historic feature of the site and asserted that remediation efforts should avoid damaging or removing them as the cleanup progressed, suggesting that this site be used to interpret the early technology of smelting in Butte. ${ }^{543}$ In an article from 2000, Fred Quivik, who was also a primary author of the 1985 Park Plan, referred to the Butte Reduction Works slag canyon as an often ignored industrial feature that was not simply worthless waste product, but rather an ingenious way to conserve its other wastes (tailings) and prevent property damage and potential litigation. $^{544}$

In 2009, the Lower Area One and Reduction Works Tailings project was more than half-way complete, and the slag walls had been saved as an important cultural landscape feature. An interpretative sign stood near one of the slag walls describing the historic use of the site, the clean-up, and the future public-use planned for the site. ${ }^{545}$ The slag walls in Butte were preserved because of the heritage planning efforts of the county, an early recognition and declaration of significance, and a well thought out approach to managing heritage amid clean-up activities. The two Anaconda smelter sites, however, were saved largely by creative thinking in the wake of significant clean-up momentum.

Anaconda Copper had largely demolished and removed the structures of the $19^{\text {th- }}$ century upper and lower smelter sites by the early $20^{\text {th }}$ century. Although some historic building foundations and toppled smoke stacks existed on the site in the early 1990s,

\footnotetext{
542 Ibid., 82 and 153.

543 "Regional Historic Preservation Plan: Butte-Anaconda Corridor,” V-21.

${ }^{544}$ See: Fredric L. Quivik, "Landscapes as Industrial Artifacts: Lessons from Environmental History," IA: The Journal of the Society for Industrial Archeology 26, no. 2 (2000).

${ }^{545}$ A Story of Rebirth, . Butte, Montana: ARCO, 2004 (est.), Interpretive Sign
} 
large extant waste slag and sinter piles from its smelting period generally had long encouraged the residents of Anaconda to use the site as a dump. The EPA estimated the volume of the historic waste piles at over 1.5 million cubic yards of flue dusts, slag, and soils contaminated with arsenic, cadmium, copper, lead, and zinc. ${ }^{546}$ Although the Engineering Evaluation/Cost Analysis work plan outlined four pages of actions required to satisfy the NHPA,${ }^{547}$ the general work plan called for the stabilization of debris piles to prevent further contamination of Warm Springs Creek during high water events which included consolidating the various piles into a single waste repository then capping and covering to prevent water leaching.

The 1985 park plan described both the Upper and Lower Works sites as largely foundations strewn with brick, stone, and abandoned waste. Although of high historical importance, the plan noted the multiple locations' low structural integrity and moderate accessibility but still called for a relatively large interpretive center and an interpreted trail along the abandoned rail bed. ${ }^{548}$ Although the interpretive center was not built, by 2009 a paved trail wound through the Upper Works site along a former rail bed with signage identifying significant features of the site and others describing the processes and people formerly tied to the site. The rest of the site with its intertwining ruins and slag and sinter piles, was capped with 18-20 inches of new soil, revegetated, and protected

\footnotetext{
546 "Old Works Engineering Evaluation/Cost Analysis-Preliminary Site Characterization," ed. PTI Environmental (Bellevue Washington: ARCO, 1991), 20, and "Old Works/East Anaconda Smelter Case Study," www.epa.gov/superfund/programs/recycle_old/success/casestud/anaccsi.htm., accessed September 20, 2008.

547 "Old Works Operable Unit: Engineering Evaluation/Cost Analysis Work Plan," ed. U.S. Bureau of Reclamation (Billings, Montana: U.S. Environmental Protection Agency, 1988), 18-22.

548 "The Butte-Anaconda Historical Park System Master Plan,” 68, 82, and 131.
} 
with a new drainage system to prevent leaching into the creek and provide a stable cover over a waste deposit, and then converted into a Jack Nicklaus-designed golf course.

During the planning and design phases, Nicklaus held steadfast to some heritage ideals, keeping many aspects of the site's ruins as part of the course. The foundations of the Upper Work's smelter building entice golfers along the \#3 and \#4 fairways, while golfers on the \#7 tee hit off of the top of a slag mound. There are no white sand traps on the course. Nicklaus filled all the traps with granulated slag, now called "sland," from the Washoe Smelter waste dump, claiming it was superior in many ways to traditional trap sand and less expensive to obtain — it was free and virtually inexhaustible given the size of the deposit. ${ }^{549}$

Who to credit for the idea of building a golf course among smelter ruins as a boost to the local economy and a first step toward rebranding Anaconda an "outdoors" destination is unclear. Several different golf course origination stories circulate, ranging from a retired smelter foreman's joke to a regional developer's "eureka" moment while playing golf in Idaho. However it started, many claimed that the course was an important defining moment for the community. Just a few years earlier, the EPA had permanently relocated the residents of the smelter town of Mill Creek because of significant arsenic contamination in homes and local soils, an event that was likely the low point in locals perception of their landscape. The golf course was designed to not only serve as a control barrier between the public and the hazardous materials underneath, but to bring in

\footnotetext{
${ }^{549}$ Old Works Vision to Reality. Video. Sand + slag = sland.
} 
120 full-time jobs and almost $\$ 900,000$ in income and spending to the community, not counting money spent by golfers. ${ }^{550}$ (See Figure 6.7)



Figure 6.7 Oldworks Golf Course showing Washoe Smelter stack in the background and "sland" traps in the foreground. The entire ARCO-funded course was designed to provide long-term cover for the hazardous wastes stored underneath, inject some income into the local economy, and retain some heritage features such as building foundations and slag piles. (Source: Author)

While some in the preservation community bemoaned the loss of the historic character of the old works and others still await the economic rewards from the course, the EPA and ARCO believe it has been a large success and that the site is ready to be

\footnotetext{
550 "Old Works/East Anaconda Smelter Case Study," www.epa.gov/superfund/programs/recycle_old/ success/casestud/anaccsi.htm, accessed September 20, 2008.
} 
removed from the National Priorities List (NPL)....All this while in sight of the Anaconda stack.

Within a year of the 1980 shutdown of the Washoe smelter in Anaconda, the ARCO subsidiary, Anaconda Minerals Company, began plans for its demolition and in 1982 hired Cleveland Wrecking and began removing parts of the site. Because of the extensive contamination of much of the debris and waste piles--estimated at 185 million cubic yards of tailings, 27 million cubic yards of slag, and 250,000 cubic yards of flue dust $^{551}$--both Cleveland Wrecking and AMC became subject to the Resource Conservation and Recovery Act (RCRA) regulations governing the handling and transportation of hazardous wastes. In 1982 EPA also began superfund procedures and listed the site on the NPL in September 1983. ${ }^{552}$ The EPA-approved demolition plan for the Washoe Smelter was rather extensive and called for removing all structures leaving only "massive concrete foundations and bulkheads... weathered bedrock, contaminated soil, pulverized brick, and some construction debris."553 Sanctioned demolition work began in 1983 and finished in $1986 .{ }^{554}$

Despite ongoing demolition and plans for the complete removal of structures, the General Work Plan (GWP) written for the smelter site five years after its NPL listing, included a five page description addressing the need for a cultural resource assessment. ${ }^{555}$

\footnotetext{
551 "Final Work Plan for Anaconda Smelter RI/FS," ed. CH2M Hill (Anaconda, Montana: U.S. EPA, 1988), $1-2$.

552 Ibid., 1-4.

${ }^{553}$ Ibid., 1-5.

554 "Superfund Program, Anaconda Co. Smelter Site," www.epa.gov/unix0008/superfund/mt/anaconda/index.html, accessed July 8, 2009.

555 "General Work Plan, Anaconda Smelter NPL Site, Attachment I," (Anaconda, Montana: U.S. EPA Region 8, 1988), 28-32.
} 
The GWP noted the need for a survey to identify sites eligible for the National Register prior to demolition work, recognized that the smelter stack was already so listed, and specifically stated that the survey to address historical, archeological, and prehistoric resources be completed within 180 days of the order to proceed. Further, it called for consideration of identified and eligible resources during the remedial investigation and feasibility study (RI/FS) and in designing remediation alternatives for the site. Unfortunately for the smelter's heritage, the GWP was finished in 1988, six years after demolition began and simply assumed that the appropriate Section 106 and 110 actions it outlined had taken place. ${ }^{556}$ The RI/FS was finished in 1991 and largely did not address heritage because most of the site was already gone.

There is no evidence that ARCO and the EPA followed through with the historical survey. In any case, little was ultimately left at the smelter site by 1988 when the General Work Plan identified the need for cultural resource assessments. Despite the fact that at a minimum some sort of documentation should have occurred, no record of this survey existed in the Superfund repositories in Anaconda, Butte, Helena, or the EPA regional office in Denver. By 1988 what was once the largest and most advanced copper smelter in the world had been completely demolished with the exception of the tallest free standing structure large stack in the world which would became the smallest state park in Montana.

Following the demolition of Great Falls stack in 1982 and the announcement of plans to demolish the Washoe smelter, several community members formed the

\footnotetext{
${ }^{556}$ Ibid., 30 and 32.
} 
"Anacondans to Preserve the Stack" committee (to distinguish itself from the Great Falls "Save the Stack" group) to pressure ARCO and state officials to leave the Washoe stack in place. According to a Relevant Authority close to the preservation movement, the group recognized it needed both local and state government support before approaching ARCO. Fortunately, committee members were only about an hour's drive from the state capital and could lobby and make meetings on very short notice. While the group's founders were related to the masons who constructed the stack in a mere three months, many in the community and the local press enthusiastically backed the plan as a monument to all smelter workers. According to another Relevant Authority, the organizers met with little resistance in Helena, and the state ultimately agreed to create a state park. ARCO for its part was also enthusiastic about stack preservation, largely because they expected much greater resistance to the smelter demolition and, the community, maybe a little short-sighted, had only asked to save one structure which would have also been very expensive for ARCO to remove. ${ }^{557}$

The 14-acre Anaconda Stack State Park sits in two parcels. One is simply the in situ stack and a small area around it on smelter hill. While at some future point, there may be limited public access or guided tours to the stack itself, in 2008 the hill parcel had restricted access because of existing soil contamination and the potential for falling bricks. The second parcel is approximately two miles away and is called the "viewing area." It includes interpretive signs describing the operations of the stack and smelter, data comparing the stack's size to other similarly tall structures like the Washington

\footnotetext{
${ }^{557}$ Conversation with a Relevant Authority (11).
} 
monument and Eiffel Tower, and a full-diameter, three dimensional brick model of the stack base that exactly replicates the stack's $75^{\prime}$ external and 60' internal diameter, while only rising four feet from the ground. ${ }^{558}$ (See Figure 6.8)

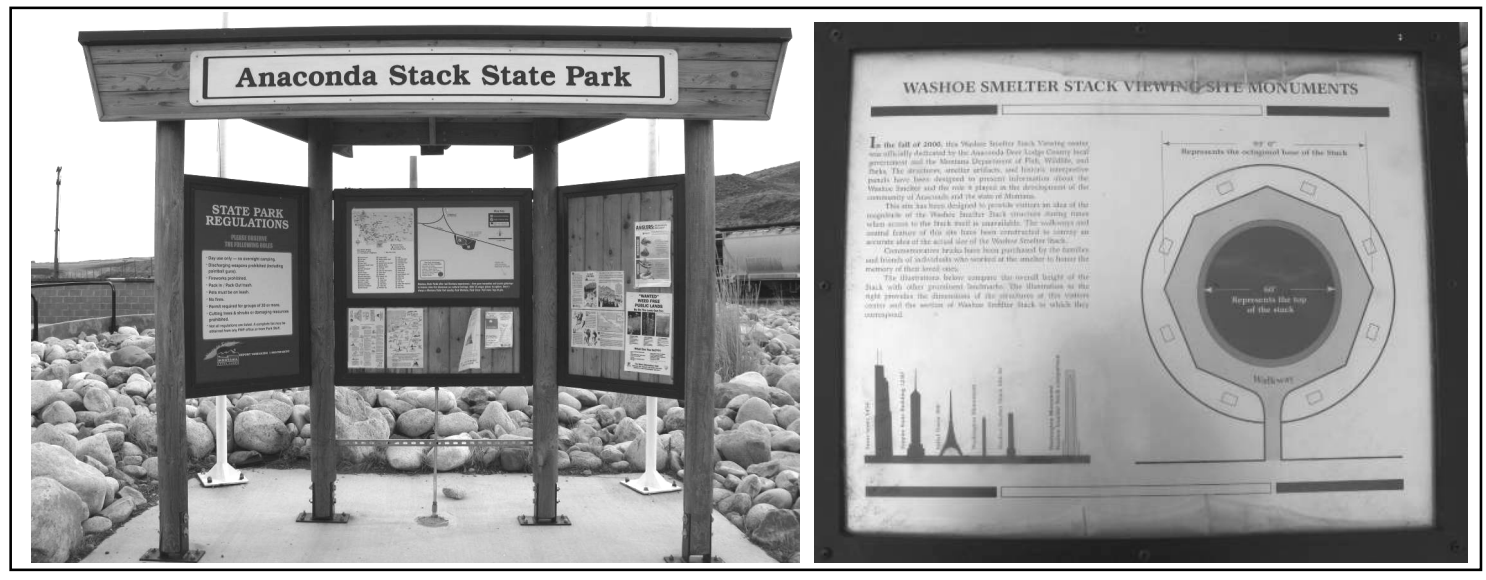

Figure 6.8 Interpretive panels at the Anaconda Stack State Park. This is a very small park in plain sight of the stack, and the interpretive displays focus on smelter operations in general and the stack specifically. (Source: Author)

The 1985 Park Plan discussed the initial public outcry over the planned stack demolition, noted that it had been converted into a state park, and largely assumed that any hope of saving any other smelter structures had been already lost. ${ }^{559}$ The plan, however, recognized the significant interpretive potential of the stack and state park viewing area and called for an expanded visitor center and outdoors museum that would include salvaged equipment from the site. Although the state installed interpretive panels describing smelter operations, replicated the stack's cross-section, and placed some equipment and ladles around the park, the formal museum and visitor's center was never constructed.

\footnotetext{
${ }^{558}$ Personal observation, November 2008.

559 "The Butte-Anaconda Historical Park System Master Plan," 68.
} 
The Anaconda stack and the Butte gallows frames provide single, simple representational brands for the heritage of the region. Although a few people opposed saving the stack, most locals embraced its preservation. Some historians might claim that the stack, when operating, was a means of non-verbal symbolic hegemony over the workforce, constantly reminding them who controlled their lives. Some economists might claim the preservation of the stack was holding the city back by preventing it from looking to the future. ${ }^{560}$ In many ways, however, the stack now stands as a reminder of what once gave the place meaning and what the region pins its hopes on for the future. Unlike the Berkeley Pit which serves more as a monument to pollution and the negative aspects of mining on the environment, the stack, although also responsible for the distribution of significant pollutants for more than a century, has become more of an icon for positive revitalization.

Almost every person I talked to in Anaconda knows the stack's height, the fact that it is still the tallest masonry structure in the world, and its association with, at one time, the greatest copper district in the world. The same goes for the Butte gallows frames. Although they were responsible for bringing toxic materials to the surface and creating acid runoff and mine drainage, their preservation is regarded by locals as a monument to the people who worked there. The other sites in the Butte-Anaconda corridor try to balance their story between the toxic and heroic, trying to turn the story of human contamination into human triumph both over the land itself and the mess made by the copper industry. Like Ducktown, Michigan, and Butte-Anaconda hopes to use

\footnotetext{
${ }^{560}$ Personal conversations with Michigan Technological University economists, 2009.
} 
historic industrial sites to revitalize its economy and draw as many tourists to the region as possible.

If a single word emerges to describe the environmental and heritage development of the Butte-Anaconda area it is the word large. Historians and locals declare that Butte had the "richest" hill, the most production, and the biggest non-ferrous minerals company in the world (for a time). Anaconda, both the town and the company, had the largest copper smelter in the world that housed the largest reverberatory and largest copper blast furnaces, and the tallest masonry structure. The district also has the largest Superfund site in terms of physical size and the largest National Historic Landmark district. It has the largest grass-roots heritage movement and the one of the largest heritage planning efforts for a superfund site.

While many of these efforts were large in size, the key feature of the heritage process in Montana was the organization of a strong bottom-up planning effort. Many of the planners were not locals at first but identified with the landscape and organized and planned for the eventual Sections 106 and 110 conflicts with EPA and ARCO with little national-level support except for expanding NHL district boundaries.

Butte also demonstrates the value of place to locals and the complimentary perceptions of new-locals who value the landscape as they first see it. The miners and laborers of the region during the 1950s-1980s witnessed the decline of their district, the loss of neighborhoods, and considerable demoralizing change. New people who moved into the region in the late 1970s and 1980s, outsiders at first, saw not necessarily the loss 
of the previous decades, but the considerable wealth of cultural resources remaining and organized, along with some long-time locals, to protect those remaining resources. While the efforts produced planning documents and led to important preservation successes, not all could be saved. Then the new comers experienced a sense of defeat over the cultural losses, especially as the cleanup gained momentum and made major changes to the landscape. Yet, people new to region in the 2000s, aware of, but not witness to, the losses of the 1950s, 1960s, 1970s, 1980s, and 1990s, but interested in heritage, are able to enjoy the results of planning efforts, preservation projects, and heritage integration into the city landscape carried out by local preservationists in the 1980s and 1990s. It is easy to be significantly impressed with the level of what was saved, not with what was lost, which is exactly the sentiment civic leaders want visitors to have.

Similar to the Butte District, the Keweenaw Peninsula saw considerable declines in its mining, leading to efforts to commemorate the past. Unlike Montana however, where heritage planning was largely organized solely from the grass roots and dominated by local planning efforts, Michigan heritage planning was driven by a combination of National Park Service, top-down planning, and the efforts of long-standing tourism and heritage groups that melded into a quasi-structured historical park. 


\section{CHAPTER 7. QUINCY SMELTER}

WHEREAS, THE Quincy Smelting works is the last remaining historic smelter left anywhere in the world and reflects smelting technologies of the late $19^{\text {th }}$ Century...

WHEREAS, the smelter site continues to severely deteriorate with open windows, roofs, and walls...

WHEREAS, the [Keweenaw National Historical Park] has not been successful in securing funds to stabilize buildings nor to restore any of the Smelter buildings for historic interpretive purposes;

NOW THEREFORE BE IT RESOLVED, that the Cities of Houghton and Hancock City Councils...do hereby support the restoration of the Quincy Smelting Works and request the Keweenaw National Historic Park make the restoration of the Quincy Smelting Works its highest priority, funded by the Federal FY 2010 budget and

BE IT FURTHER RESOLVED, that if this effort to restore the Quincy Smelting Works is not funded by the Fiscal Year 2010 Federal Budget, the facility be recommended for demolition in the interest of public safety and blight removal, and allow redevelopment opportunities to be undertaken by Franklin Township.

-Houghton Hancock, Joint City Councils Resolution (2007)

The first historic mining-related landscape feature a visitor to the Michigan

Copper Country sees and recognizes is likely a head frame. Most visitors pass dark sand beaches unaware they're looking at stamp sands and drive through Michigan

Technological University, not knowing that this is the $21^{\text {st }}$-century incarnation of the Michigan School of Mines founded in 1885. No, the first physical element that most visitors likely notice is the Quincy shaft-rock-house that is part head frame, part sorting building. It sits on the apex of Quincy Hill just up from the Portage Lake waterfront. Like the Butte gallows frames, the clean, reclad shaft rock house is a ubiquitous postmining symbol appearing in many images and forms throughout the region.

But much more like the trip from Ducktown to Copperhill than the trip from Butte to Anaconda, as visitors proceed north along US Highway 41 and approach downtown Houghton, they may notice a largely disheveled conglomeration of historic buildings in 
various states of disrepair on the waterfront across the narrow lake. While not as large or imposing as the Copperhill site, this collection of structures, belonging to the smallest of the big-three $20^{\text {th }}$-century smelters on the Keweenaw Peninsula, is almost as intact as it was when it closed in 1971 after 73 years of service. Most people in the region desire some sort of positive development of such a visible and valuable piece of waterfront property. While some would like to see the buildings preserved and interpreted as an important historic site with mixed-use public function space, others, citing blight and decay, call for their complete removal to allow for new residential or commercial opportunities. This dichotomous sentiment is echoed in the Joint City Council resolution quoted above.

Copper smelters and smelting landscapes in general receive only modest heritage attention often because smelters create some of the largest environmental problems. They tend to get demolished and remediated quickly after their functional use is gone. While many mining museums talk about smelting, there are virtually no copper smelting museums and, compared to mining heritage sites, almost no preserved and interpreted American copper smelter sites or partial sites exist outside of the fading 30-acre parcel behind the Ducktown Museum, the Anaconda Stack, and, to a lesser degree, the Old Works Golf Course. Even in Swansea, Wales, home to the single greatest concentration of copper smelters ever, there is little homage to and virtually no remains left of the historic industry of the town.

The Michigan copper district, however, has an opportunity to change the perception of smelting and its technological, social, and ecological effects on the 
metallurgical production system. The Quincy is the only near-complete historic copper smelter site in the world with in situ reverberatory furnaces and related equipment, offices, support buildings, and still-occupied homes of smelter workers. (See Figure 7.1) The site sits within the Quincy Mine National Historic Landmark district, is a former Historic American Engineering Record documentation project, and is a significant contributing site to the Keweenaw National Historical Park (KNHP). (See Figure 7.2) Unfortunately, the site is also part of the Torch Lake Superfund project and at various times has been considered for both full preservation and full demolition. The smelter's current owner, Franklin Township, does not have the resources to invest in the preservation of the site, which has largely sat unattended and unmaintained since its last heat in 1971, slowly succumbing to the ravages of harsh winters and vandals.

Although the site is a contributing location to the KNHP, the National Park Service Washington Headquarters requires careful analysis and consideration before allowing its individual parks to own or get too involved with sites saddled with contamination or liability issues. Further, Congress, in the 1992 enabling legislation that created KNHP, specifically excluded NPS from acquiring properties that have significant Superfund contaminants. Complicating the preservation of the smelter site, EPA, in its zeal to identify at least one potentially responsible party (PRP) to pay for part of its Superfund cleanup in the area, named the NPS a PRP because the Park had assisted the township with preservation and use planning. This ultimately forced KHNP to step back from assisting the township until the Superfund liabilities were removed. 


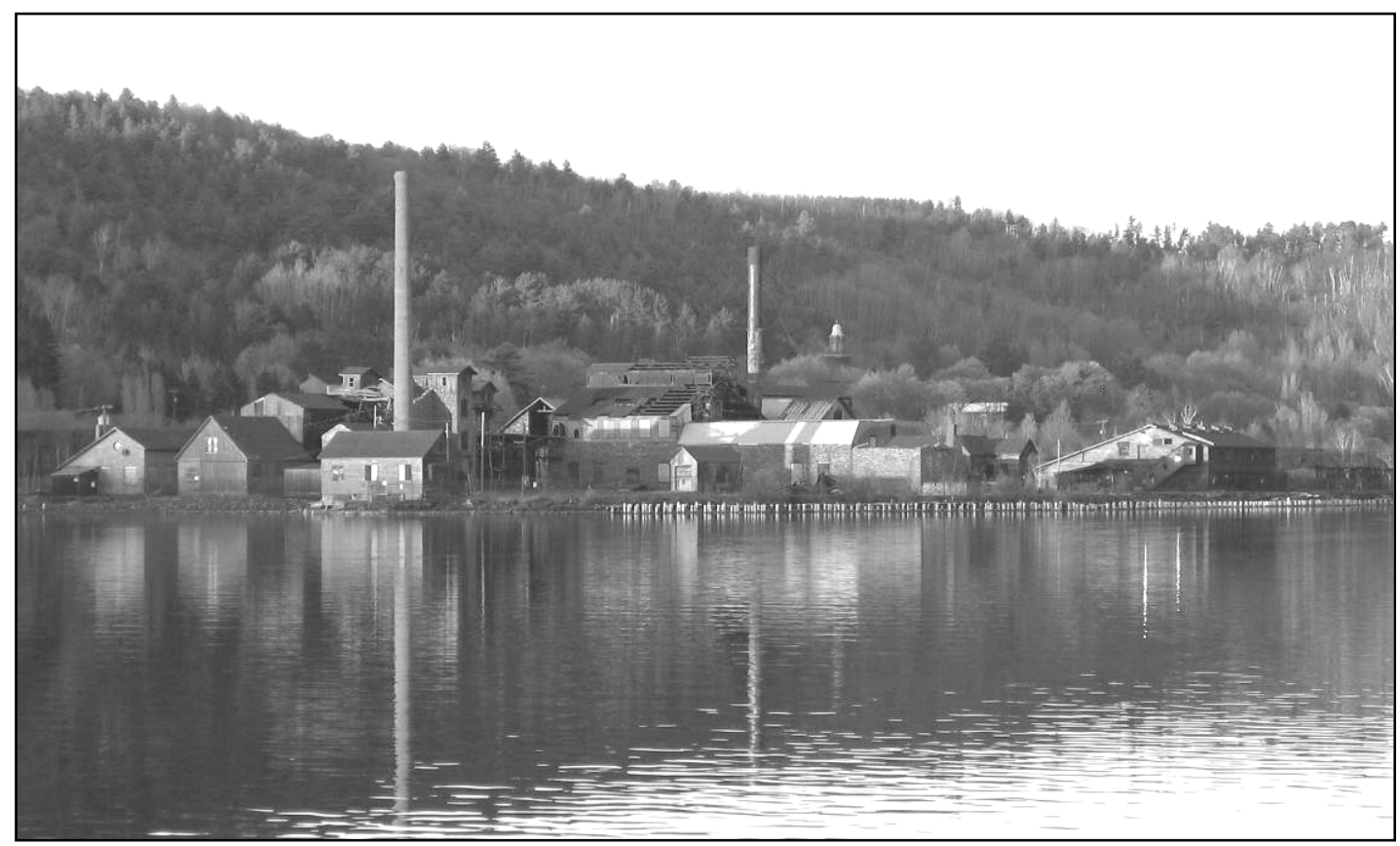

Figure 7.1 Quincy Smelter Site 2008. (Source: Author)

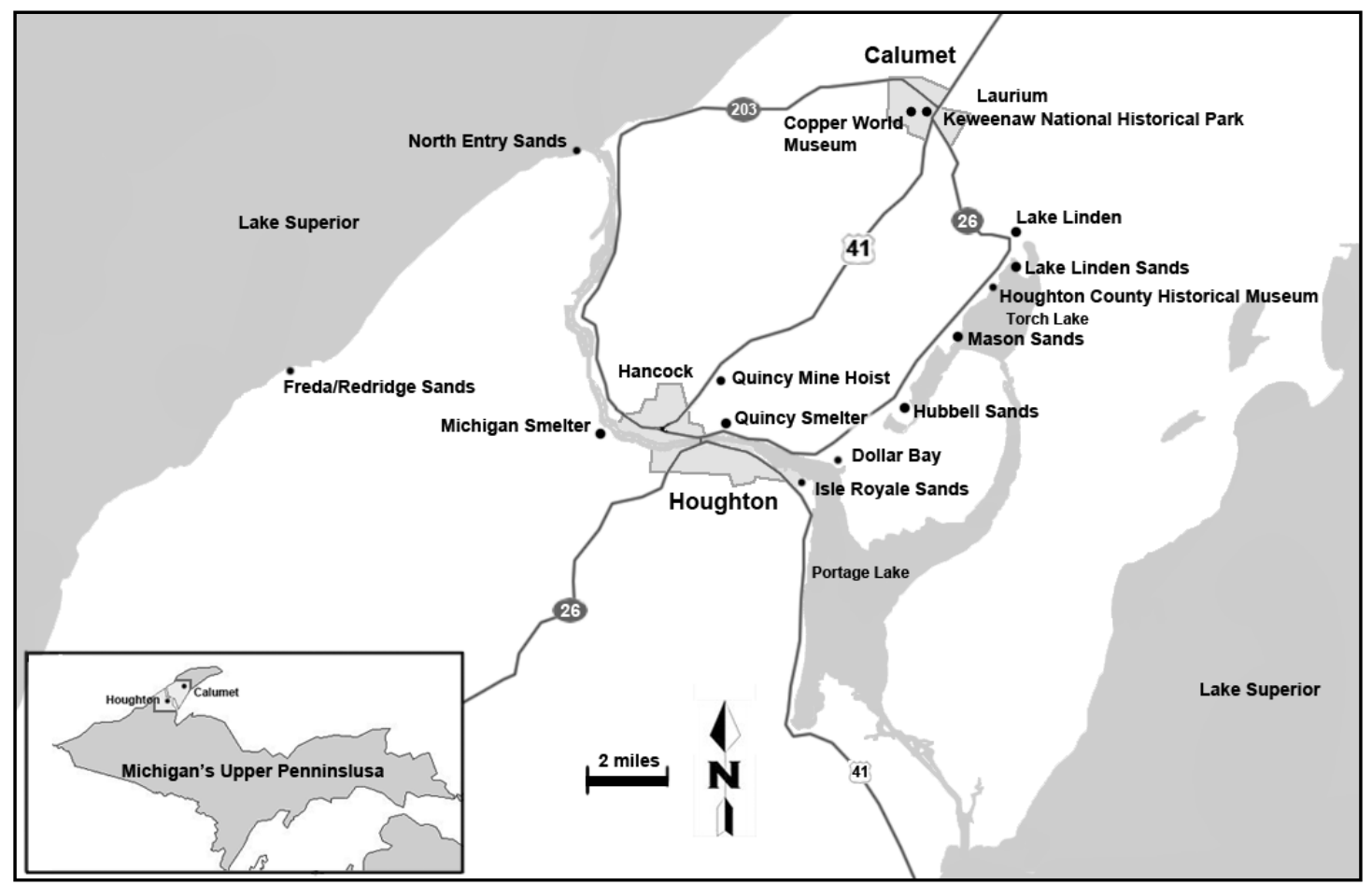

Figure 7.2 Map of the Keweenaw showing selected heritage and remediation sites. (Source: Author) 


\section{Shutdown}

During the 1930s both the Tennessee Copper Company and Anaconda Copper Mining Company came to completely dominate production in their respective districts, controlling almost all mining, milling, and smelting operations. Both companies continued their singular hold over their regions until large, multi-national petroleum companies bought them in the $1960 \mathrm{~s}$ and $70 \mathrm{~s}$, but continued to produce copper or related chemicals into the 1980s. Unlike both Ducktown and Butte, Michigan copper mining did not coalesce into a single corporate entity. Instead, three companies of the 300 or so native copper mining companies chartered in Michigan survived until the district ceased operations, with one of the three, the Calumet and Hecla, outliving and out-producing the Copper Range Company and Quincy Mining Company. ${ }^{561}$ Also, while Tennessee and Montana copper mines both worked the same veins for a century, Michigan's copper mines worked multiple ore types stretched over 100 miles in three different Keweenaw Peninsula counties, leading to multiple starts, shutdowns, and abandonment of various regional mining districts, often leaving ghost towns scattered throughout a still-active mining region.

Although Michigan copper mining production peaked in the late 1910s, its prominence on the world stage began declining in the 1880s as Butte copper production matched then surpassed Keweenaw output. From 1847-1880, Michigan copper mines produced nearly $75 \%$ of US domestic copper, reaching a high of $82 \%$ in 1880 , just as

\footnotetext{
${ }^{561} \mathrm{C} \& H$ ended mining in 1969 and although Quincy ended native copper mining in 1945, its mills continued through 1967 and its smelter until 1971. Copper Range ended native copper mining in 1967, but its copper sulfide operation continued in Ontonagon County until 1997.
} 
Montana silver mines reached the rich Butte copper lodes. ${ }^{562}$ Between 1880 and 1884 , annual copper production outside of Michigan rose from 10 million pounds to 76 million pounds, causing a price drop from $\$ 0.20$ per pound to $\$ 0.14$ over the same period, and a further drop to $\$ 0.11$ per pound in 1885 . In an attempt to arrest the growth of Montana mines and stabilize the market, Calumet and Hecla dumped excessive amounts of cheap copper on the market between 1886 and 1887 and forced the price down to $\$ 0.10$ per pound - lower, it hoped, than the production costs of many newer western mines. Despite underground fires at C\&H mines in 1887 that reduced its production and forced the company to halt its plan to control the market, several small and marginal Montana copper producers went out of business. The plan, however, ultimately failed to affect the Anaconda Copper Mining Company, whose 1887 output dominated Butte copper production and led Montana past Michigan to become the dominant copper district in the world. By 1890, Michigan mines were producing 39\% of the US total and by 1900 only $24 \%{ }^{563}$

Keweenaw copper production, however, continued to grow despite mounting complications. As with all mining districts, the remaining Michigan ores got leaner as the richer veins were mined out. Further, Michigan copper mines became some of the deepest mines in the world following copper veins to distances of over 9,000 feet from

\footnotetext{
${ }^{562}$ Charles K. Hyde, Copper for America: The United States Copper Industry from Colonial Times to the 1990s (Tucson: University of Arizona Press, 1998), 66.

${ }^{563}$ Ibid., 60 and 66. Perception of the importance of Michigan mines changed too in the late $19^{\text {th }}$ century. Once the standard copper for electrical use because of its natural purity, native copper ultimately became just another electrical-copper because the purity of electrolytic-refined copper easily matched the $99.9 \%$ pure Michigan metal. In fact in 1892, a New York electrolytic-refining copper firm began marketing "Nichols-Lake Substitute" copper. (Curtis Cravens, Copper on the Creek: Reclaiming an Industrial History (New York: Place in History, 2000), 11.
} 
the surface by 1920 , while the deepest Butte mines were operating at 3,800 feet, and Arizona mines, largely open pits, did not have to venture further than 2,915 feet down. ${ }^{564}$ Despite the increased costs associated with deeper mining of leaner ores, Michigan companies were able to take advantage of technologies such as compressed air, electricity, and the one-man rock drill to remain cost competitive, produce copper cheaper than their Western competitors through the 1910s, and continue to pay dividends through WWI. During the war and after mandated price controls ended, however, the production-cost advantage of Michigan mines changed to a $10 \%$ cost disadvantage in 1916 , increasing to $30 \%$ by $1920 .{ }^{565}$

Despite the persistence of profits, adoption of new technologies, and increasing production through 1916, the overall productivity of Michigan mines began declining before the war. The largest and costliest strike in the district began in 1913 partly over cost-cutting measures such as the one-man rock drill and workers' wages and hours. Although the mining companies prevailed, workforce problems persisted and even worsened as miners left the area to find better jobs out West, new immigrants avoided the region because of limited work during the strike, and new, well-paid manufacturing jobs especially in Detroit, led to a general exodus of workers. Compounding these problems, WWI drew young men into the armed forces, contributing to a cumulative labor-force drop from 15,000 mining workers in 1915 to 8,000 in $1920 .^{566}$

\footnotetext{
${ }^{564}$ Larry Lankton, Cradle to Grave: Life, Work, and Death at the Lake Superior Copper Mines (New York: Oxford University Press, 1991), 245.

${ }^{565}$ Hyde, Copper for America : The United States Copper Industry from Colonial Times to the 1990s., 7679.

${ }^{566}$ Lankton, Cradle to Grave: Life, Work, and Death at the Lake Superior Copper Mines, 244.
} 
Although the post-war economic recession affected the copper industry nationwide, the pre-war conditions that began affecting Michigan production worsened in the 1920s. In 1921, many Michigan copper mines temporarily shut down to allow stock piles to be sold off and, in the process, posted their lowest production levels since 1889 and, for the first time since 1847 , did not pay a single dividend. ${ }^{567}$ Despite declines and difficult economic conditions, mining continued on the Keweenaw, and would continue in some instances for almost fifty more years, but the dominance of the region had clearly faded as the remaining mines introduced new practices and diversified while they struggled to extract the last bits of profit from the local rock.

Discussed in Chapter 4, C\&H looked toward alternative sources of income and savings and began "mining" its waste tailings in 1915, recovering copper through leaching and flotation processes at half the cost of underground work. ${ }^{568}$ In 1919, Quincy began installing the largest steam hoist ever constructed, capable of winding 12,000 feet of cable and quickly moving men, rock, and materials to and from the deepest parts of its 9,000-plus-foot-deep mine. Following depression era mine closures and WWII-era production, it too began recovering lost copper from its tailings and operated its reclamation mill through 1967 and its smelter through 1971.

Although Quincy ended underground mining the day its last government contract expired in 1945, Copper Range and C\&H further consolidated existing mines and diversified their corporate holdings to remain in metals production. ${ }^{569}$ Copper Range

\footnotetext{
${ }^{567}$ Ibid., 244-245.

${ }^{568}$ Ibid., 249-250. C\&H continued to process its tailings until WWII.

${ }^{569}$ Ibid., 259.
} 
closed its mills and smelters shortly after WWII, but opened the copper sulfide-bearing White Pine Mine in Ontonagon County after the United States entered the Korean War. Although the company maintained a native copper mine on the Keweenaw through 1967 to supply copper to its subsidiary companies and transitioned through several owners, it mined, milled, and smelted White Pine sulfide ores until 1997. C\&H, which had purchased and developed a number of profitable subsidiary companies by the mid 1960s, became attractive to corporate takeover. In 1967, Universal Oil Products (UOP) absorbed $\mathrm{C} \& \mathrm{H}$ and, in 1969, in the midst of significantly declining mining returns and a growing labor dispute, closed the last $\mathrm{C} \& \mathrm{H}$ mine, ending the era of native copper production in Michigan. ${ }^{570}$

\section{Note on Smelting Sites}

Shortly after Copper Range closed its Michigan Smelter in 1950, the company demolished the site and recovered any saleable materials. It then contracted its remaining Keweenaw smelting needs to Quincy, leaving behind only the foundations and abutments of its once important smelting works. ${ }^{571}$ Quincy continued to operate its smelter through the end of its tailings reclamation and the closure of Copper Range's last native copper mine (the Champion in Painesdale), both in 1967, and processed scrap copper at the site until 1971. (See Figure 7.3) When pollution concerns mounted with the State of Michigan who began insisting on the installation of pollution control equipment, Quincy

\footnotetext{
${ }^{570}$ Ibid., 262.

${ }^{571}$ The site still stood in 2009 as a large and open ruin with no complete structures except for the original office building that is now serving as a residence.
} 


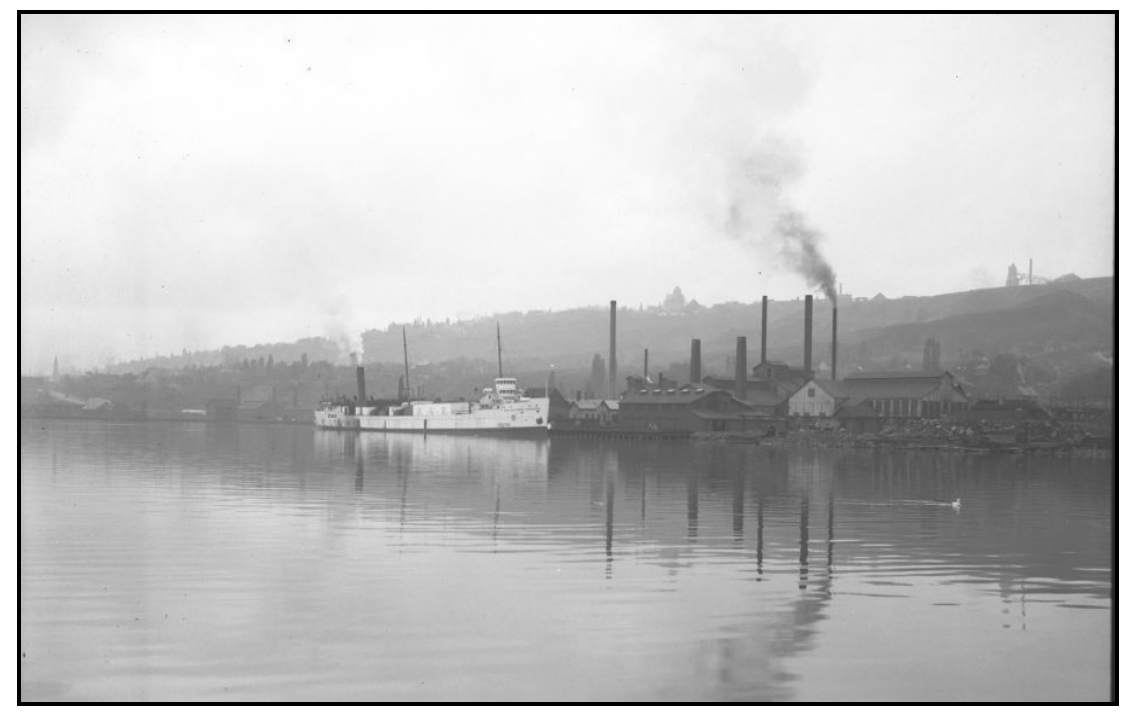

Figure 7.3 Quincy

Smelter ca. 1920.

(With permission of

Michigan Tech

Archives and Copper

Country Historical

Collections.)

simply abandoned the site without scheduling any demolition or environmental reclamation, and transferred ownership to the Quincy Development Corporation, an entity formed to manage or sell the mining company's lands. The smelter site, one of the most complete of any in the world in a heritage context, was ultimately donated to Franklin Township in 1999 in lieu of back taxes for development into a museum in partnership with the National Park Service.

The C\&H smelter closed in 1969 along with the cessation of mining and sat vacant until 1982, when Michigan Tech Ventures, a private corporation created by Michigan Technological University (MTU) to generate local business opportunities using and promoting MTU-developed technologies, formed Peninsula Copper Industries (PCI). PCI, with technological support from MTU, adapted a C\&H process to recover copper from scrap materials such as circuit boards and electrical wires, to create copper-oxide chemicals for commercial purposes. PCI moved its operations into the $1912 \mathrm{C} \& \mathrm{H}$ 
electrolytic plant at the smelter and used the blacksmith shop and former cupola buildings for storage. Most other buildings on site had been or were ultimately demolished, leaving a patchwork of foundations and disused transportation corridors in $2009 .{ }^{572}$

Of the other smelter sites that once processed Michigan native copper in the Keweenaw, several sat partially developed or as undeveloped ruins in 2009. The Dollar Bay works site still retained foundations, and a few of the Lake Superior Smelter buildings still stood intact, reused by the Houghton County Road Commission in Hancock. The short-lived 1847 Isle Royale and Ohio smelter site on Isle Royale still had foundations of demolished structures and some abandoned equipment, while the Lake Superior Native Smelter Works site, which was converted to a foundry in the early 20th century, had no visible features left except an altered shoreline. None of the other Michigan smelter sites listed in Table 4.2 retain any physical features. ${ }^{573}$

\section{Early Environmental Concerns}

Unlike the noxious gases produced from sulfide smelting in Montana and Tennessee that caused visible and severe damages to the environment and personal property, Michigan smelting was relatively benign, and as such, did not substantially injure non-mining property or generate significant early concerns among residents and governments about landscape degradation. In fact, forest vegetation and insect populations were at times so thick because of long summer growing days, that residents

\footnotetext{
${ }^{572}$ Dan Trepal, "The Calumet \& Hecla Smelting Works: 1887-2006," Unpublished graduate paper available at Michigan Technological University Archives, (Houghton, Mich.: Michigan Technological University, 2006), 24.

${ }^{573}$ Personal observations 2006-2009.
} 
in some respects looked forward to the winter fallow season and the availability of ice roads on frozen lakes and rivers to ease overland transportation difficulties. ${ }^{574}$ Michigan's copper mining operations, like similar operations in other districts, used significant amounts of lumber to shore up mines and heat residences and dumped its stamp sands in local waterways. Although its coal-fired boilers and smelters produced smoke, none of the ultimate effects were greater than any other industrial district and were largely accepted as the price of mining from the 1840s until the 1960 s when pollution became an important issue across the country and the EPA began examining levels of more invisible toxins associated with mining wastes. ${ }^{575}$

\section{Origins of the Heritage Movement}

All three of the broader regions studied in this work became tourist destinations because of their rugged mountainous landscapes, perceptions of purity and pristine wildernesses, and rich histories. Butte and Ducktown, however, as specific locations within a larger destination region, were largely shunned by early tourists because their industrial and urban natures belied the expected pristine wilderness of their surroundings. Historical environmental problems only exacerbated this perception. Smoke-generated moonscapes, enormous settling ponds, dirty streets, and the persistent hum of industrial

\footnotetext{
${ }^{574}$ Lankton, Beyond the Boundaries, 12.

${ }^{575}$ Although lawsuits against Michigan Copper Mines for property damages were rare if they occurred at all, late $19^{\text {th }}$ century tailings deposits into Portage Lake ultimately resulted in significant obstructions to navigation requiring dredging by the Army Corps of Engineers to maintain the waterway. Strong (2002) demonstrated that significant tailings deposits from 1882 to 1886 had reduced the already constricted the navigable water by more than $66 \%$ at one location in east Houghton. See: Katherine Strong, "Shoreline Change Along the Portage Canal," Unpublished graduate paper available at Michigan Technological University Archives. (Houghton, Mich.: Michigan Technological University, 2002), 5.
} 
activity well in to the 1980s acted to repel most nature-seeking visitors. While the Tennessee Copper Basin was largely remediated by the 1990s, and Butte-Anaconda was investing in historic preservation and heritage interpretation in the 2000 s, they were both far behind the Keweenaw Peninsula in attracting recreational visitors. While Ducktown had an environmental stigma since the 1920s and Butte had a significant stigma since the 1970s, the Michigan district was never really affected by degradation issues that impacted tourists.

Michigan copper production began its final decline after WWII. But unlike Montana and Tennessee, its copper industry did not take on new, more destructive forms to stay alive, like the open pits of Butte and the continued production of copper-based organic chemicals and acids on a very large scale like Ducktown. Further, because of its pure copper deposits, its smelting industry never contaminated the local environment to the degree as the other locations. So, just as the mining industry started seeing significant declines in the $20^{\text {th }}$ century and negative associations of environmental degradation were nonexistent, the automobile and growing middle class incomes afforded a means for people to escape crowded urban areas, and the Copper Country provided a perfect natural attraction.

Geographically, the Michigan copper district was different too. Both Tennessee and Butte copper districts were located close to scenic destinations and national parks, and in the case of Butte, on a major interstate thoroughfare. These enabled automobile travelers to avoid industrial areas despite the drive for tourism dollars in economically declining regions. Michigan's copper district happened to be at the end of the road, and 
its mines were shutting down at a time of increased wealth and a bit of post-war wanderlust brought on by returning GIs in the 1920s and 1950s. Michigan's copper district was located in an area of reputed scenic beauty and because it was the destination, as opposed to near the scenic destination, it drew more people directly in the 1920s-1960s than the much more industrially active Montana and Tennessee copper districts. Further the Keweenaw Peninsula was reachable in a day's drive by millions of people from Illinois, Wisconsin, Minnesota, and lower Michigan.

By the late 1930s, tourism was Michigan's second leading industry after automobile manufacturing, and with increased personal incomes, the Upper Peninsula became an important draw for its natural beauty and low population density. Natural beauty alone, however, was not necessarily a powerful enough draw to create a tourism market in the Upper Peninsula. According to Aaron Shapiro, tourism required careful planning, development, management, and packaging by a variety of people and organizations. ${ }^{576}$ Early in the century, several Michigan development and tourism boards created programs specifically to lure Detroit, Chicago, Milwaukee, Minneapolis, and even Cleveland residents. They included the Upper Peninsula Development Bureau founded in 1911, whose Cloverland publications touted the virtues of northern Michigan vacations and whose support of the Hartman-Rushton Act (MI) helped pass the 1929 law creating a funded and coordinated tourism-development organization that in 1937 became the Michigan Tourist Council. ${ }^{577}$ A second, more local organization, the Copper Country

\footnotetext{
${ }^{576}$ Aaron Shapiro, "Air Conditioned by the Cool Breezes of Lake Superior: Vacationing in Michigan's Copper Country," in New Perspectives on Michigan's Copper Country, ed. Alison K. Hoagland, Erik C. Nordberg, and Terry S. Reynolds (Hancock, Mich.: Quincy Mine Hoist Association, 2007), 135. ${ }^{577}$ Ibid., 137.
} 
Vacation League, made up of local merchants, resort owners, and mining company representatives formed in the 1920 s to promote the Keweenaw Peninsula specifically.

While the Keweenaw held some of the same toutable vacation advantages as other parts of the Upper Peninsula and Northern Wisconsin, it remained cooler in the summer with Lake Superior cross winds blowing across the narrow land mass. Further, the Keweenaw offered much greater access to the Great Lake with over 100 miles of shoreline, and the opportunity to drive "to the end of highway US 41," whose southern terminus reached the ocean in Miami, Florida. Enhancing the scenic draw, a fair number of early heritage tours sprang up utilizing the area's abandoned mine sites, ghost towns, and historic forts. To get to Keweenaw County, where many of these were located, however, drivers had to pass directly through what was left of the declining Michigan copper district centered in Houghton County, and, during the inter- and post-war periods, several local entrepreneurs created mining-related attractions to lure tourists. ${ }^{578}$ Where Montana and Tennessee copper districts used heritage to create a tourism market, Michigan's early tourism market created the first heritage sites in its mining region. (See Figure 7.4)

The 1926 Cloverland Tourist Guide advertised Houghton, Michigan, as "the most cosmopolitan community in the Copper Country.... and the gateway and very heart of copperdom." For tourists, the city offered good boating, bathing, and fishing, no hay fever, and interesting historic sites nearby including "Fort Wilkins, the Douglas

\footnotetext{
${ }^{578}$ Ibid., 144-145.
} 




Figure 7.4 Tourism on Keweenaw Peninsula. The person on the left worked at both the Arcadia Tourist Mine and Copperama before coming to the Quincy Mine Hoist. The sign on the right, touted the salubrious nature of the region from the 1950s. (Both images with permission of Michigan Tech Archives and Copper Country Historical Collections.)

Houghton Memorial, and famous copper mines, mills, and smelters." ${ }^{579}$ Nineteen-thirties Works Progress Administration projects supported tourism infrastructure including the construction of lodges, golf courses, and scenic drives. While these were the early beginnings of heritage tourism, it was the post-WWII period that saw the creation of specific mining-related and heritage attractions on the landscape.

One of the first post-war tourism destinations came out of a failed attempt to restart mining in the abandoned Arcadian mine across the lake from Houghton during WWII. While this venture ended with the death of its founder in 1943, it left behind an unusual horizontal mine shaft one mile off the main highway to Keweenaw County. In 1951, the Arcadian's new owners developed it into the first underground "tourist mine" in Michigan and likely the nation. For over 34 years, the mine guided visitors 1500 feet

${ }^{579}$ Cloverland Tourist Guide (Menomonee, Michigan: The Herald-Leader Company, 1926), 32. 
into the rock face and even garnered recognition from Life Magazine in $1962 .^{580}$

Copperama, another site that opened some time in the 1950s or 1960s, sat right on the main highway one mile south of Houghton. While documentation is sparse on this shortlived attraction, an undated, existing flyer claimed a "fascinating, highly educational underground tour at one of Michigan's oldest copper processing sites" located at the Isle Royale stamp mill that closed in $1948 .^{581}$

One of the longest lived of the mining heritage sites and museums began in 1958 following a tour of the 1920 Quincy Mine Hoist by the American Institute of Mining Engineers (AIME). The members of the group, captivated by the size of the machine and recognizing its significance to mining engineering, formed the Quincy Mine Hoist Association with a governing board that included representatives of the local AIME chapter, the Nordberg Manufacturing Company (original makers of the hoist), Michigan Technological University, the Quincy Development Corporation, and the public. The new organization petitioned the Quincy Mining Company for a 99-year lease on the abandoned structure, intent on preserving the hoist and associated buildings as an engineering landmark. The Quincy Mining Company provided initial funding through a \$50,000 no-interest loan (whose repayment was ultimately forgiven) and a significant eight-to-one matching grant fund. ${ }^{582}$

In 1968 the Quincy Mine Hoist Association opened for its first tours. In 1970, the site was listed on the National Register of Historic Places and in 1978became the center

\footnotetext{
580 "Arcadian Mining Property Once the Rival of C\&H," Daily Mining Gazette, June 24, 1978. 581 unknown, "Copperama " (ca. 1960) Available at the Michigan Technological University Archives. 582 "Options for National Park Service Involvement in the Management of Historic Copper Mining Resources on Michigan's Keweenaw Peninsula," ed. Midwest Region National Park Service (Omaha, Nebraska: National Park Service, 1988), 3.
} 
of a Historic American Engineering Record documentation project that included the mining company's smelter, shaft rock house, mills, and other support buildings. ${ }^{583}$ The preserved buildings ultimately led to a National Historic Landmark designation in 1989 and became one of the key factors in the formation of the Keweenaw National Historical Park in 1992.

Although many tourist attractions focused on the region's history, no site had been as historically significant as the Quincy Mine Hoist and none had really had as long an impact on the region's heritage. While the recognition that the site could become a tourist stop did not escape the governing board's founders, they understood that the site had greater value than just an income generator. The preservation of such a significant site contributed to a HAER documentation project and National Historic Landmark designation, and, in many ways, sparked regional heritage curiosity.

The area's untouched historic and archeological sites ultimately lured industrial historians and archeologists, several previously involved in HAER work and state industrial projects, to Michigan Technological University. This grouping coalesced into a graduate program in industrial archeology. Further, the growing interest in industrial history, the importance of Michigan's copper mining to United States history, and the level of preservation in the region led to the formation of the Keweenaw National Historical Park in 1992 amid mounting concern about the lasting environmental effects of the district's mines, mills, and smelters.

\footnotetext{
${ }^{583}$ Erik C. Nordberg, "Quincy Mine Hoist Association Anniversary Banquet," booklet available at Michigan Technological University Archives (Hancock, Michigan: Quincy Mine Hoist Association, 2008)
} 


\section{Later Heritage - Keweenaw National Historical Park}

Although the Keweenaw National Historical Park falls into the temporal realm of post-mining later-heritage and regional redevelopment, its creation was a direct result of early and on-going heritage activities generated from the creation of regional tourism in the 1920s and 30s and the preservation of the Quincy Mine Hoist. Congress created the Keweenaw National Historical Park in October 1992, following nearly two decades of studies and plans.

The first attempt at a regional historical park began in 1972 when Universal Oil Products funded the design of "Coppertown, USA," a large open-air museum intended to rival Greenfield Village in Dearborn, Michigan. The attraction planned to feature mining exhibits, copper products displays, ethnic and cultural centers, festival plazas, arts areas, new hotels, and a 70' tall miner statue. While the full concept proved a bit too ambitious for the time and never was constructed, a much more modest indoor museum in the old C\&H pattern shop emerged with traditional interpretive displays on the region's history and a not-surprising emphasis on $\mathrm{C} \& \mathrm{H}^{584}$

In the mid 1970s, the Historic American Engineering Record conducted broad surveys of American industrial areas to identify significant historic regions and cultural resources in its realm of interest. In 1977, it followed up a survey of Michigan's Lower Peninsula with a survey of its Upper Peninsula. In addition to identifying iron mining, timber, power, and transportation resources, the survey documented Michigan's Copper Country, identifying a significant number of intact mining resources, including the fairly

\footnotetext{
584 "Options for National Park Service Involvement in the Management of Historic Copper Mining Resources on Michigan's Keweenaw Peninsula," 3-4.
} 
complete system of worker housing, and the mine, mill, and smelter sites of the Quincy Mining Company. Because of the high integrity of the Quincy sites, which included the mine hoist, HAER scheduled a full site documentation of the Quincy for 1979. That summer a large group of architects and photographers recorded the site's physical features, and a group of historians wrote its technological and social history, providing a copious amount of formal historical research justifying the region's significance. ${ }^{585}$

Although the idea of a national historical park first surfaced in 1974, the movement reemerged and gained true momentum following a Governor's tourism conference in 1986. Locals hit on the idea of a national park to stop the decay of Calumet, once the center of the region's copper mining industry, and began to pressure Michigan's influential congressmen. Ultimately responding to a congressional request, the NPS researched and published Options for National Park Service Involvement in the Management of Historic Copper Mining Resources on Michigan's Keweenaw Peninsula in 1988. Although this report neither recommend nor dissuaded a park, it demonstrated the feasibility of a park and, if a park were to be established, proposed two units, one at Quincy anchored by the existing mine hoist and one in Calumet centered on the Coppertown Museum. ${ }^{586}$ The report also articulated the need for National Historic Landmark (NHL) district nominations for the two areas to demonstrate the high integrity and national significance required for a national park. ${ }^{587}$ The Options report and subsequent NHL nominations led to a study of alternative designs that examined a variety

\footnotetext{
585 Ibid., 4.

586 "Final General Management Plan and Environmental Impact Statement," ed. Keweenaw National Historical Park Michigan (Calumet, Michigan: U.S. Department of the Interior, 1998), 7.

587 "Options for National Park Service Involvement in the Management of Historic Copper Mining Resources on Michigan's Keweenaw Peninsula," 6.
} 
of potential park arrangements and ultimately recommended a two-unit park managed under cooperative agreements with the NPS. The new park would actually own just a few key buildings and relatively little property, but would support affiliated sites both within the park boundaries and related sites outside the boundaries that agreed to operate and run programs to certain standards, and promote historic preservation and adaptive reuse of buildings and landscapes. ${ }^{588}$

Congress passed Public Law 102-543 creating the Keweenaw National Historical Park (KNHP) in 1992 to: "tell the story of the role of copper in the development of an American industrial society and the effects on the Keweenaw Peninsula of providing the copper" and "identify, study, and preserve significant historical and cultural sites, structures, districts and landscapes...for the education, benefit, and inspiration of present and future generations....and develop and sustain into the $21^{\text {st }}$ century the park and the community through a blend of private, local, state, and federal management, investment, and ownership." ${ }^{589} \mathrm{KNHP}$ officially came into existence with the signature of the President, and the NPS in Washington allowed the new unit to proceed with land acquisitions, staff building, and limited financial assistance to partnership sites. Although KNHP had a fair degree of autonomy in deciding how to proceed, one important clause in the law, section 4 (b) restricted the park from acquiring lands that were contaminated with hazardous substances. ${ }^{590}$ This clause forced KNHP to explore only those parts of an

\footnotetext{
588 "Final General Management Plan and Environmental Impact Statement," 50.

${ }^{589}$ Ibid., 13-14.

${ }^{590}$ Ibid., 175.
} 
industrial landscape that had not housed industrial activity that might have produced hazardous wastes, such as mills and smelters.

Thus the Keweenaw National Historical Park owns only five buildings in the park either a former administrative, warehouse, streetcar, or commercial facility but does not own any site where industrial processes occurred. It originally partnered with 23 existing, privately-owned and operated historic sites, a reflection of the region's early involvement in heritage tourism, to interpret the region as a whole. Although several of the sites have gone out of business over the years, by 2008 the list of heritage partner sites in the region included the Adventure Mining Company, A.E. Seamen Mineral Museum, Calumet Theatre, Chassell Heritage Center, Copper Range Historical Museum, Coppertown Mining Museum, Delaware Copper Mine, Finnish American Heritage Center at Finlandia University, Fort Wilkins State Park, Hanka Homstead, Houghton County Historical Museum, Keweenaw County Historical Society, Keweenaw Heritage Center at St. Anne's, Laurium Manor Mansion Tours, Old Victoria, Ontonagon County Historical Museum, Porcupine Mountains Wilderness State Park, Quincy Mine \& Hoist, and the U.P. Firefighters Memorial Museum. ${ }^{591}$

\section{Superfund}

Concurrent with the formation of KNHP, the Environmental Protection Agency was exploring the very same historic landscape for hazardous mining wastes from a century of past activity. The local genesis of the Torch Lake Superfund site began with a

\footnotetext{
591 "Keweenaw Heritage Sites," National Park Service, http://www.nps.gov/kewe/parkmgmt/keweenawheritage-sites.htm, accessed June 25, 2009.
} 
Michigan environmental law designed to control pollution. Michigan's revised constitution of 1963, Article 4, stated that

...the conservation and development of the natural resources of the state hereby declared to be of paramount public concern in the interest of the health, safety, and general welfare of the people. The legislature shall provide for the protection of the air, water, and other natural resources of the state from pollution, impairment, and destruction. ${ }^{592}$

Although this declaration mirrored developments nationally and seemed to suggest that human welfare was of equal importance to the future exploitation of natural resources, the first laws restricting pollution, implementing Article 4, did not surface until the Michigan Environmental Protection Act of 1970 and State's clean air and clean water acts in the 1970s.

Although Superfund would become the driving policy affecting clean up of Michigan copper mining wastes, State of Michigan departments drove the initial investigations into contamination in the area. In 1973, the Michigan Water Resources Commission investigated a 27,000 gallon cupric ammonium carbonate discharge that occurred in Lake Linden between 1971 and 1972. Although no "deleterious effects" were reported because of the spill, it raised awareness of other potential mining contamination and prompted state investigations into regional fish abnormalities called locally the "Torch Lake Tumors," and the long-term deposit of xanthates and creosotes from milling operations. Further, in 1985 an International Joint Commission designated the Torch Lake basin a "Great Lakes area of concern" because of potential contamination. Although many of the fish tumors had disappeared by the early 1990s,

\footnotetext{
592 James M. Olson, Michigan Environmental Law: A Guide to Environmental Law (Traverse City, Mich.: Neahtawanta Press, 1981), 10.
} 
high levels of mercury and PCBs were found, and fish consumption advisories remained in effect in $2009 .^{593}$

Although the first formal implementation of mining-related pollution controls in the Keweenaw came from the State of Michigan and affected the organization and construction of the White Pine mine, mill, and smelter in the 1950s, and the final closure of the Quincy Smelter in 1971, the state would ultimately cede control over the abandoned wastes to the federal government. The state investigated or supported investigations into copper tailings and slag wastes that ultimately contributed to the official listing of Torch Lake on the Superfund National Priorities List in 1986. After that EPA became the primary governmental entity to formally document past environmental conditions, plan for remediation, and attempt to seek a responsible party to pay for the cleanup under CERCLA. Although the EPA took charge, in most cases, studies and remediation plans were developed with the consultation of the State of Michigan Department of Environmental Quality.

Unlike the Butte and Ducktown districts, the pollution problems in the Keweenaw from mining operations were relatively benign and not considered a high human health risk. The EPA classified the region an environmental risk related mostly to the deposition of tailings, slag, and airborne dusts, and ancillary industrial activity such as chemical leaks and discarded storage drums. According to the Torch Lake Second Five Year Report:

\footnotetext{
593 "Second Five-Year Review Report for the Torch Lake Superfund Site," ed. Region 5 U.S. EPA (Chicago: U.S. EPA, 2008), 12 and 18.
} 
Torch Lake was the site of copper milling and smelting facilities and operations for over 100 years. The lake was a repository for all mining related waste...Copper was extracted through a series of technologies...first by crushing or "stamping" the rock...then by grinding... The copper and crushed rocks were separated by gravimetric sorting in a liquid medium. The copper was then sent to the smelter. The crushed rock particles called "tailings" or "stamp sands" were discarded along with mill processing water, typically by pumping it into the lakes and streams...Dredges were used [starting in 1916] to collect submerged tailings which were screened, re-crushed, and gravity separated. An ammonia leaching process involving cupric ammonium carbonate was used to recover copper... During the 1920s chemical reagents were used to further increase the efficiency of reclamation...[and] included lime, pyridine oil, coal tar creosotes, wood creosote, pine oil, and xanthates. After reclamation...chemically treated tailings were returned to the lakes. ${ }^{594}$

Over the course of a century, more than 200 million tons of tailings and reclamation wastes were dumped into Torch Lake filling approximately $20 \%$ of its volume. Despite national prohibitions on creating obstructions to navigable waterways established by the Rivers and Harbors act of 1890, Torch Lake was specifically exempted. The lake was further exempted from dumping laws when mining increased during WWII.

During early site investigations conducted under CERCLA, EPA discovered empty drums at mill and smelter sites along Torch Lake, and over 800 drums dumped on the lake bottom. While those determined to have once contained hazardous substances were removed and disposed of at a hazardous waste landfill, many of the empty drums on the lake bottom were simply left in place. ${ }^{595}$

Curiously, the EPA did not aggressively pursue Potentially Responsible Parties (PRP) at this superfund site despite the fact that Universal Oil Products (UOP), Quincy Development Corporation, and the Copper Range Company still existed at the time of the

\footnotetext{
${ }^{594}$ Ibid., 17.

595 "First Five-Year Review Report for the Torch Lake Superfund Site," ed. Region 5 U.S. EPA (Chicago: U.S. EPA, 2003), 13.
} 
NPL listing. EPA began exploring cost recovery options in 1986, but, following unsubstantiated claims from UOP that the EPA would make local private landowners fund the clean up or that UOP would sue local land owners if it were required to pay, EPA withdrew its pursuit in 1988, claiming it was doing so to assuage local fears about protracted federal lawsuits. A more significant factor in deciding not to pursue PRPs may have been that the total cost of the Torch Lake cleanup was estimated at a mere \$15.2 million as opposed to over \$1 billion in Butte-Anaconda and likely several hundred million dollars in Ducktown, and that the cost of pursuing UOP, Quincy Development, and Copper Range would have incurred attorney fees and time costs much higher relative to the cost of the cleanup. ${ }^{596}$ Also, the contamination was not a significant human health risk, but rather just an environmental risk and thereby a lower priority cleanup. In the long-run, EPA may have simply found it less costly to pay for the work from the "superfund" generated from petroleum and chemical taxes.

While many of the documented incidents of hazardous substances in the Keweenaw region were relatively minor, the primary concern and target for remediation came from existing tailing and slag waste deposits. From the First EPA Five Year report on Torch Lake:

The continuous release of tailing- and slag-borne contaminants via wind, surface water runoff, and wave erosion are deemed to represent an unacceptable and actionable source of ecological risk. The most severe ecological impact is the degradation of benthic communities (bottom dwelling organisms) associated with contaminated sediments in Torch Lake and other water bodies at the site. The benthic community is an integral part of the base of a complex food web in lakes. A severely impacted benthic community would impact the entire food web. Toxic effects due to heavy metals (especially copper) appear to be related to

\footnotetext{
596 "EPA Completes Construction at Torch Lake," ed. Region 5 U.S. EPA (Chicago: U.S. EPA, 2006), 1.
} 
sediment pore space dynamics and seem not to have significant water column impacts. $^{597}$

The general plan for remediation thus became to arrest the flow of tailings- and slaggenerated toxins into the air and water, and the EPA identified Torch Lake itself and 13 specific sites on Torch Lake, Portage Lake, and Lake Superior that had large waste deposits. EPA ultimately broke the sites into three operable units to manage. The plan, according to 1992 record of decision (ROD) was to:

1. Reduce or minimize potential future risks to human health associated with the inhalation of airborne contaminants from the tailings and/or slag located at the site; 2. Reduce or minimize potential future risks to human health associated with direct contact with and/or the ingestion of the tailings and/or the slag located at the site; 3. Reduce or minimize the release of contaminants in tailings to the groundwater through leaching; and 4. Reduce or minimize the release of contaminants in tailings to the surface water and sediment by soil erosion and/or air deposition. ${ }^{598}$

The thirteen specific locations were divided geographically into Operable Units 1 and 3, while Torch Lake made up Operable Unit 2. ${ }^{599}$

OPERABLE UNIT 1
10. Mason Sands
11. Hubbell/Tamarack City
12. Lake Linden Sands
$\frac{\text { OPERABLE UNIT } 2}{\text { Torch Lake* }}$

\section{OPERABLE UNIT 3}

$\begin{array}{ll}\text { 1. Calumet Lake } & \text { 6. Michigan Smelter } \\ \text { 2. Boston Pond } & \text { 7. Quincy Smelter } \\ \text { 3. North Entry } & \text { 8. Isle Royale Sands } \\ \text { 4. Redridge* } & \text { 9. Dollar Bay } \\ \text { 5. Freda* } & \text { 13. Point Mills }\end{array}$

*No action taken

Although the record of decision called for no action regarding OU2 (Torch Lake)

because the lake was recovering on its own, the general plan of remediation for the majority of other sites was a four part system of debris removal and grading of the

\footnotetext{
${ }^{597}$ Ibid., 15.

598 "Proposed Plan for Record of Decision Amendment for Operable Unit 3 at Torch Lake Superfund Site," ed. Region 5 U.S. EPA (Chicago: U.S. EPA, 2008), 2.

599 Ibid., 3.
} 
tailings and slag deposits, followed by a $6-8$ inch soil cap to arrest blowing and erosion, topped by a vegetative layer to keep the cap intact and help shed water and prevent public exposure, and finally deed restrictions to ensure the remedy remained intact. ${ }^{600}$ There were, however, a few exceptions to this treatment besides Torch Lake. Portions of the Isle Royale Sands southeast of Houghton were being redeveloped for a sewage treatment plant, and some of those stamp sands were used in concrete block manufacture. Part of the Point Mills sands were being used for winter road traction, and sands at Freda and Redridge were exposed to heavy Lake Superior wind and wave action and thus exempt.

Except for one location, none of these sites had significant standing historic structures eligible for the National Register, and thus Sections 106 and 110 issues did not apply to the EPA's work despite arguments that the stamp sands themselves could be considered a significant historic landscape feature representing major man-made changes to shorelines. ${ }^{601}$ The lone-exception was the National Historic Landmark-designated Quincy Smelter site, built on stamp sands created by the earlier Pewabic and Franklin mills. From the 2008 Proposed Plan for ROD amendments:

The Quincy Smelter...includes 25 buildings, which historically operated as a copper smelting facility during the 19th and 20th centuries until 1969. The Quincy Smelting Works is a significant component of the Quincy Mining Company National Historic Landmark District established in 1989. This district is also within the boundaries of the Quincy Unit of Keweenaw National Historic Park. Franklin Township owns the Quincy Smelter complex and is interested in developing and restoring the area as part of the national park. Activities conducted under EPA's 4 Superfund Redevelopment Initiative (SRI) have

\footnotetext{
600 "First Five-Year Review Report for the Torch Lake Superfund Site," 16-18.

601 "Responsiveness Summary, Torch Lake Superfund Site, Operable Units I and II, Houghton County, Michigan," ed. Region 5 U.S. EPA (Chicago: U.S. EPA, 1992), RS-30.
} 
identified Quincy Smelter as having passive recreational use and historical representation (historic site) use. $^{602}$

The smelter soon became a contentious issue for the region. The EPA and Michigan Department of Environmental Quality (MDEQ) claimed that the stamp sands on which the smelter was built were prone to airborne disbursement and that its slag piles contained high quantities of heavy metals and considered demolition as a potential early remedy. ${ }^{603}$ Local developers claimed the deteriorating buildings were an eyesore, that prime waterfront real estate was being wasted, and argued that the buildings should, therefore, be demolished. ${ }^{604}$ The National Park Service argued that the smelter buildings were not only part of a National Historic Landmark district, but they were affiliated with the Keweenaw National Historical Park and part of the one of the last historic copper smelter complexes in the world, and represented a significant component of the local industry and should therefore be preserved. ${ }^{605}$ The State Historic Preservation Office, generally in charge of Sections 106 and 110 issues, largely deferred to the NPS. ${ }^{606}$

\footnotetext{
602 "Proposed Plan for Record of Decision Amendment for Operable Unit 3 at Torch Lake Superfund Site," 3. 603 "Declaration for the Record of Decision, Torch Lake Site, Michigan, Operable Units I and II," ed. Region 5 U.S. EPA (Chicago: U.S. EPA, 1992), 19, and "EPA Proposes Cleanup Plan for Quincy Smelter Erosion," ed. Region 5 U.S. EPA (Chicago: U.S. EPA, 2008), 1.

${ }^{604}$ Kurt Hauglie, "EPA to Host Smelter Hearing," Daily Mining Gazette, January 12, 2009.

${ }^{605}$ James Corless, "The Significance and Status of the Quincy Smelting Works, Franklin Township, Michigan (White Paper)," ed. Keweenaw National Historical Park (Calumet, Michigan: (unpublished ) Keweenaw National Historical Park, 2008), 1.

606 "Programmatic Agreement among the Michigan State Historical Preservation Officer, Michigan Technological University and Keweenaw National Historical Park, National Park Service (U.S. Department of the Interior), Regarding the A.E. Seaman Mineralogical Museum Adaptive Reuse Project, Er06-107," ed. Michigan State Historic Preservation Office (Lansing, Michigan: MISHPO, 2006), 2, and Corless, "The Significance and Status of the Quincy Smelting Works, Franklin Township, Michigan (White Paper)", 7. While the existence of the Programmatic Agreement does not implicate the Michigan SHPO in avoiding Section 106 of NHPA responsibility for the Quincy Smelter site, it demonstrates a willingness to enter into agreements to allow other interested parties, such as the NPS, to enforce compliance at sites quite distant from the State capital. The White Paper written by NPS officials suggested that NPS "exercised its authority granted by the National Historic Preservation Act to comment on and influence the activities of a
} 
Meanwhile, locals split between preservation, commercial development, and complete demolition.

\section{Quincy Smelter}

When selecting Keweenaw sites to be documented by HAER, choosing properties to include in the National Historic Landmark district, and defining the boundaries of the Keweenaw National Historical Park, heritage professionals in each case included the Quincy Smelter site on Portage Lake for its integrity as a historic location and significance to regional and ultimately national copper production. While other significant contributing sites such as Coppertown Museum and the Quincy Mine Hoist were under fairly stable ownership, the smelter had sat largely unused and abandoned since its closing in 1971, suffering annually from the insalubrious affects of heavy winters and chronic vandalism. Unfortunately for the site, the KNHP implementing legislation forbade the new national park from acquiring the site because of potential hazardous wastes and its listing on the NPL. The Quincy Smelter is the only Keweenaw site listed specifically on both the National Historic Landmark District form and National Priorities List.

The EPA and MDEQ evaluated Keweenaw stamp sand and slag deposits based on the potential for redevelopment and potential exposure to hazardous substances, primarily antimony, arsenic, copper, and vanadium. While many of the toxins had acceptable thresholds for temporary exposure, such as at parks or recreation areas, the exposure

federally funded project with potential adverse affects on a national historic landmark," (p. 6-7) These responsibilities would be the same for the SHPO under those circumstances. 
threat became much more chronic if people were going to be spending considerable time near the deposits, if the deposits were to be disturbed, or if children could be at risk of ingestion, primarily the case if the areas were redeveloped into housing. Because of this high risk, the EPA instigated the soil cap and vegetative cover remedy for sands that had the potential for new housing. ${ }^{607}$

The slag piles and stamp sands at the Quincy Smelter tested high for copper, antimony, and chromium, which contributed to its rating of chronic hazard for prolonged exposure. Copper was singled out as the "most pronounced contaminant" for potential children residing at the smelter site, but antimony was also rated a high health risk. ${ }^{608}$ Further, the slag piles also tested high for cadmium and chromium. ${ }^{609}$ (See Figure 7.5) However, unlike the Torch Lake stamp sands, the smelter site from the beginning of the Superfund process had been considered for potential inclusion in the Keweenaw National Historical Park with minimal exposure risks for visitors and staff. ${ }^{610}$ In the 1992 Declaration for the Record of Decision, the EPA stated:

Assuming that the slag pile located in the Quincy Smelter Area (Appx. 25 acres) will be developed as part of a National Park, no action will be taken. If the area is not developed in the future, then deed restrictions will be sought to prevent the development of residences in the slag pile area. ${ }^{611}$

\footnotetext{
607 "Record of Decision, Decision Summary, Torch Lake Sites, Operable Units I \& II, Houghton County Michigan," ed. Region 5 U.S. EPA (Chicago: U.S. EPA, 1992), 27.

${ }^{608}$ Ibid., 27.

609 "Final Remedial Investigation Report, Operable Unit III" ed. Region 5 U.S. EPA (Chicago: Donohue and Associates, 1992), 4-3.

610 "Record of Decision, Decision Summary, Torch Lake Sites, Operable Units I \& II, Houghton County Michigan," 27.

611 "Declaration for the Record of Decision, Torch Lake Site, Michigan, Operable Units I and II," 3.
} 




Figure 7.5 Aerial view of Quincy Site 1990. Showing collections of historic buildings (a) and slag piles (b). (Source:

Michigan Tech Archives and Copper Country Historical Collections.)

In 1992, the same year the Keweenaw Park was formed, the EPA decided that no action was required at the smelter site as long as it was developed as a historic attraction without individual long-term exposure to hazardous wastes. Even if not developed, the EPA decided it would only seek deed restrictions before considering taking the site off the NPL. Unfortunately, the enabling legislation for the park prevented federal ownership of the site, but not technical and financial assistance provided to the site owner. In 1999 the KNHP worked with the site owner, Quincy Development, to transfer the site to Franklin Township with the intention that the park would provide planning and technical assistance and at some point in the future, lease, or otherwise develop the site if legally permitted. In addition to funding smelter documentation and research projects, and providing technical expertise, restoration cost estimates, and planning concepts to the 
township over the next five years, KNHP also provided guidance to EPA in the erection of a security fence to protect trail users from friable and blowing asbestos. ${ }^{612}$

Despite the EPA's 1988 decision not to pursue potentially responsible parties and its expectation, if not support, for the inclusion of the smelter site in the KNHP, EPA and MDEQ interpreted the expenditure of NPS planning funds and its attempt "to impose restrictions on the location of protective fences," as signs of tacit ownership, and the agency's enforcement branch went after KNHP as a new PRP. ${ }^{613}$ In a modified formletter received by the KNHP on June 28, 2004, the EPA's Region 5 Emergency Enforcement and Support Section claimed that it was planning to upgrade security, prepare health and safety plans, perform comprehensive asbestos sampling, and remove asbestos and any other hazardous substances it found at the Quincy Smelter site. Further, the letter claimed to have received "information that $[\mathrm{KNHP}]$ owns or operates the facility or generated or transported hazardous substances that were disposed of at the facility," and encouraged the park

as a potentially responsible party, to agree to reimburse the U.S. EPA for costs incurred to date and to voluntarily perform or finance the response activities which the U.S. EPA has determined or will determine are required at the facility. ${ }^{614}$

While this effort appeared to have little merit based on the intentions of the NPS, it caused an immediate cessation of action by the local park staff and an order by the NPS regional director to have no further direct involvement with the site beyond technical

\footnotetext{
${ }^{612}$ Corless, "The Significance and Status of the Quincy Smelting Works, Franklin Township, Michigan (White Paper)", 7.

${ }^{613}$ Ibid., 7.

614 "Letter from EPA Region 5 to Frank Fiala, National Park Service-U.S. Department of the Interior," (Chicago: 2004).
} 
expertise, leaving the care and future of the site to Franklin Township, a governmental unit with little excess revenue to fund the preservation and redevelopment of a 25structure National Historic Landmark site listed on the National Priorities List. ${ }^{615}$

The site languished under a perplexing cloud with EPA both supporting and subverting potential restoration and redevelopment. While the EPA was ready to take "no action" and delist the site in the 1990s, the State of Michigan DEQ kept insisting that the EPA work to remediate known toxins in the stamp sands and slag and remove asbestos discovered in the early 2000s. The EPA did not initially pursue actions because of the potential for a PRP, such as the NPS, to pay for the cleanup, but it did remove hazardous materials stored in drums and ultimately abated asbestos at the site while awaiting resolution of the National Park Service role. ${ }^{616}$ The NPS, in the mean time, could not contribute to restoration planning because of its potential responsibility and liability. Franklin Township could not apply for Brownfield, coastal zone management, or preservation grants because of the NPL designation. Meanwhile, the site continued to disintegrate more with each passing winter, leading to further public controversies reflected in the joint city councils resolution cited at the beginning of this chapter.

Public controversy, however, accompanied this superfund project from the beginning. At early public meetings, residents commended the attempts to save the smelter site and criticized the efforts to cover other stamp sands, recommending that "EPA establish a defined protocol for the protection of these remarkable resources

\footnotetext{
${ }^{615}$ Corless, "The Significance and Status of the Quincy Smelting Works, Franklin Township, Michigan (White Paper)," 7.

616 "Proposed Plan for Record of Decision Amendment for Operable Unit 3 at Torch Lake," ed. Region 5 U.S. EPA (Chicago: U.S. EPA, 2008), 4.
} 
whenever they are encountered in any remediation activity."617 Others clearly

admonished the EPA for considering an option not to remediate the smelter site and some stamp sands because the potential for any toxicity must be addressed. ${ }^{618}$ The EPA responded, that by law it was

required to consider all applicable or relevant and appropriate requirements (ARARs) in selecting and implementing the remedial action. National Historic Preservation Act and Historic Sites, Buildings, and Antiquities Act are some of the ARARs to be considered... U.S. EPA will work with the MDNR (Michigan Department of Natural Resources), local townships, and necessary agencies to protect the historically valuable resources. In addition, based on the development of certain areas as a historical park, the U.S. EPA has excluded those areas from the selected remedy. ${ }^{619}$

The lack of development or preservation activity with the smelter site after more than a decade of discussion coalesced a group of local citizens to form a support group initially called Save Quincy Smelter, but later formalized into the Quincy Smelter Association. Conceived and formed by non-heritage professionals, the group initially called for the development of a shopping area and crafts center in the restored buildings. While this approach was not enthusiastically received by other stakeholders, especially local city managers whose struggling downtown business districts could use less competition, the controversy served to increase discussion about the site in the community and force other stakeholders to find more reasonable solutions that could satisfy the desires of the community and needs of historic preservation. While the Quincy Smelter Association eventually backed away from the shopping development

\footnotetext{
617 "Responsiveness Summary, Torch Lake Superfund Site, Operable Units I and II, Houghton County, Michigan," RS32.

${ }^{618}$ Ibid., RS30-RS32.

${ }^{619}$ Ibid., RS32-RS33.
} 
concept, it has held several fundraisers and supported small projects around the site and been a public voice for the community. ${ }^{620}$

In 2006, new inspections demonstrated that stamp sands at the smelter site continued to erode into the lake. ${ }^{621}$ Further, the majority of the 12 superfund sites originally listed in the region had been officially remediated and, with deed restrictions in place, effectively became eligible for delisting from the NPL and available for appropriate redevelopment. ${ }^{622}$ This action, largely accomplished by 2005 , pushed the EPA toward finalizing the last remediation plans for lingering sites.

But no formal activity to expand the national park to include the smelter site had occurred, and MDEQ continued to push for remediation projects, while the EPA began exploring options to finish its work at the smelter. With the intent of ultimately amending the ROD regarding the smelter site from "no action because of National Park formation" to some remediation to meet its primary objective of eliminating existing hazards and the requests of MDEQ, EPA began planning for final remediation efforts. However, because of the joint Houghton-Hancock City Councils resolution calling for demolition of the smelter if no park partnership developed cited at the start of this chapter, U.S. Senator Carl Levin (Mich.) convened a series of stake-holder conference calls in 2007 with Michigan Department of Environmental Quality, Franklin Township, the Natural Resource Conservation Service of the USDA, Michigan Technological University, and the Keweenaw National Historical Park specifically to engage all parties

\footnotetext{
${ }^{620}$ Personal observation.

621 "Proposed Plan for Record of Decision Amendment for Operable Unit 3 at Torch Lake Superfund Site," 4.

622 "EPA Completes Construction at Torch Lake,"1 and 3. By 2004, the Lake Linden sands and Hubbell/Tamarack locations had been delisted from the NPL.
} 
interested in the site and find a lasting solution to preserve and remediate the site. ${ }^{623}$ Curiously, the Michigan State Historic Preservation Office neglected to join the conversations, largely relying on NPS for Sections 106 and 110 guidance.

Several key decisions came from these meetings. First, it opened a dialogue between the national park and EPA regarding the issue of superfund liability, ultimately resulting in a revocation of the EPA's 2004 PRP claims on the NPS. ${ }^{624}$ Second, it allowed Franklin Township and key heritage experts at the National Park and MTU a voice in the final solution for the site. Third, it encouraged direct discussions with EPA and regional stake holders interested in preservation and, with progress, likely encouraged Senator Levin, a long-time supporter of Copper Country preservation projects, to identify funding in the National Budget earmarked for the smelter site. Fourth, with progress toward preservation, Copper Country Preservation, Inc. (CCPI), a non-profit organization and wholly owned subsidiary of the KNHP advisory council, organized to support the park's mission and partner sites, decided to support the smelter and local appropriations as its first fund-raising project. In addition to a wide-spread letter-writing campaign supported by the National Parks Conservation Association, a national parks advocacy group, CCPI successfully lobbied the cities of Hancock and Houghton to each pledge $\$ 5,000$ in 2008 for the restoration of the smelter site, an action called for in their 2007 resolution that also identified demolition as a potential option. ${ }^{625}$

\footnotetext{
${ }^{623}$ Personal involvement with the conference calls and follow up meetings.

624 "Letter from EPA Region 5 to Mr. Jim Corless, Superintendant, Keweenaw National Park," (2009)

${ }^{625}$ Garrett Neese, "Smelter Group Seeks Money from Council," Daily Mining Gazette, September 25, 2008.
} 
The EPA, fully aware of the historic nature of the site from the beginning and anxious to finish the project, now decided to remove the exiting slag piles and grade, cap, and vegetate all the exposed stamp sands outside the fence EPA erected in 2004 to secure the cluster of historic buildings on site to appease MDEQ. (See Figure 7.5) But with evidence citing the chemical stability of slag, including the Old Works Golf Course slagtraps in Montana, EPA, following input from NPS and MTU, decided to leave the large slag piles in place with some form of passive deterrence to prevent direct public access and remediate the rest of the areas outside the fence line much like other stamp sands in the district. ${ }^{626}$ The revised plan was presented to the public at a January 2009 meeting with a follow up presentation of final design alternatives and ROD amendment scheduled for late July $2009 .^{627}$ (See Figure 7.6)

Although the smelter site is a long way from restoration, the decision to pursue a historic site rather than demolition and new construction seems to be fairly well established in the community. In late June, 2009, Senator Levin announced an additional $\$ 1,000,000$ for the smelter was expected to be earmarked for the 2010 Federal Budget. $^{628}$ This appropriation, however, still had to be approved by the full Senate and survive the Senate/House conference committee and, even if approved, it won't be able to be spent until winter breaks in 2010 .

\footnotetext{
626 "Proposed Plan for Record of Decision Amendment for Operable Unit 3 at Torch Lake Superfund Site," 5. 627 "EPA Proposes Cleanup Plan for Quincy Smelter Erosion,” 1.

${ }^{628}$ Kurt Hauglie, "\$1 Million Earmarked for Smelter," Daily Mining Gazette, June 27, 2009.
} 




Figure 7.6 Quincy Smelter Base map for proposed final remediation 2009. The area inside the dashed lines will be graded, covered with soil, and vegetated to arrest erosion. The slag plies (b) will be left alone but some passive restraint will be erected, such as a short fence. The arrows indicate new water drainage from the hillside. The buildings will not receive any further remediation treatment beyond the asbestos removal of 2008. (Source: EPA, Proposed Plan for Record of Decision Amendment for Operable Unit 3 at Torch Lake Superfund Site, 5)

If the Ducktown district is defined by the landscape and in Montana everything is large, then Michigan can be seen as the most diverse and least clustered. Its mines were spread over three counties and 100 miles, it had three large mining companies in its eras of high production and declines instead of one. It had the deepest mines and simplest processing. It had the largest number of individual stakeholders involved in cleanup and heritage conflicts including the EPA, NPS, MTU, the State of Michigan, many different cities, three counties, and 19 contributing heritage sites.

But its overall heritage planning was an odd mix of top-down planning coming from the National Park Service and, at the superfund sites, EPA and the only partially 
active State of Michigan, and, of course, bottom-up planning coming from the many heritage sites, the grass-roots groups that advocated the national park designation, and the Quincy Smelter Association. However, because of the partnership nature of the KNHP and its limited staff size, the park does not impose much control over the partner sites and provides only limited technical and financial assistance. However, it does have the resources and bureaucratic infrastructure to consider district-wide planning initiatives, unavailable to and likely unnecessary for individual sites, and the legal department of a federal bureaucracy to respond to letters "encouraging it, as a PRP, to pay for environmental restoration." At the same time, its partnership nature has limited the funding available to it for long-term restoration projects, thus forcing the NPS to work to find outside funding for projects it cannot afford.

The superfund project had only two direct impacts to the heritage of the region. First, it covered a considerable area of stamp sands that some considered benign and an essential part of the region's character. Second, although EPA wanted to walk away from the Quincy Smelter in 1992 (and not expend any remediation funding), it was forced to find a compromise solution between a slowly developing historic preservation plan advocated by a United States Senator, and the MDEQ's desires for full remediation. While the solution does not address either concern fully, it does respect and respond to the most important components of both sides: protection of the historic structures and slag piles and a cap-and-cover solution for a substantial portion of the stamp sands to remediate questionable health dangers. 


\section{CHAPTER 8. CONCLUSION}

Two key factors combined to drive the dramatic technological change in American copper mining and smelting in the $19^{\text {th }}$ century. First, copper demand increased at such a rate in the industrial and modern periods that supply often required significant modifications to existing European technologies to reach greater output and efficiency. Second, expansive lean and sulfur-rich lodes were discovered that required complex mechanical, chemical, and thermodynamic procedures to economically extricate the copper from its ores. American copper demand was so great, and many of its primary ores so lean, that the industry further required massive corporate organizations and labor forces to ensure profitable scales of operations. Important $19^{\text {th }}$ and $20^{\text {th }}$ century copper mines operated in more than twelve states. ${ }^{629}$ But such extensive copper recovery from ores, largely between $0.5 \%$ and $2 \%$ rich, meant that mining, milling, and smelting generated a considerable amount of waste, ultimately leading to significant environmental problems and significant Superfund remediation projects managed by the U.S. Environmental Protection Agency in, among other places, Montana, Tennessee, and Michigan.

By 2008, copper production in the United States was largely concentrated on very low grade porphyry deposits in a few mining districts in Arizona, Utah, New Mexico, Nevada, and Montana, and processed at one of only three smelters in Arizona or Utah. Although the U.S. no longer had the largest output in the world, it still produced 1.25 million metric tons of copper and processed scrap in 2008, which was a little above the

\footnotetext{
${ }^{629}$ The most important copper mines operated in Vermont, Tennessee, Michigan, Colorado, Montana, Idaho, New Mexico, Utah, Arizona, Nevada, California, and Alaska.
} 
yearly U.S. average for the preceding century. ${ }^{630}$ Montana copper production, the smallest of five producing states, came from Montana Resources, Inc. in Butte, and a small portion of the total scrap handled in America came from Peninsula Copper, Inc.'s reprocessing of discarded copper-rich components and wire at the former Calumet and Hecla Smelter site in Hubbell, Michigan.

Both the 2008 Montana and Michigan copper operations were relatively insignificant reflections of what the industry once meant to the economies of both regions, but in some small measure, the once dominant regions were still producing copper-rich materials using means and methods developed decades earlier. The economic and technological continuity with the past contributed to the heritage and identities of both regions, especially as they neared the end of controversial Superfund remediation projects. Although Tennessee had no active copper-related industry left after its last chemical plant closed in 2008 , it too was nearing the end of active remediation.

The Superfund projects in each district defined the end, maybe even the bitter end, of their once dominant mineralogical periods. While two districts created noteworthy by-product processes, all three developed significant mining, milling, and smelting processes on a scale that created jobs, social structures, regional identities, waste streams, and significant wealth, the latter mostly for outside investors. While there tended to be a fairly fluid exchange of mining workers and engineers between active

\footnotetext{
630 "Copper Statistics and Information," USGS Minerals Information, http://minerals.usgs.gov/minerals/pubs/commodity/copper/, accessed July 8, 2009, and U. S. Geological Survey, "Copper Statistics," U.S. Geological Survey, http:// minerals.usgs.gov/ds/2005/140/copper.pdf, accessed July 8, 2009. Despite average production over 2 million metric tons per year in the late 1990s, the average annual production of refined copper including scrap in the US, from 1908-2008, was 1.19 million metric tons. In 2008 Chile and Peru were the top two copper producers in the world.
} 
mining districts, later and older generations tended to stay put, especially as production ended. Those later residents had to face the ultimate decline of production and the indignities of not only deepening mineralogical insignificance, but the implicit culpability of being a party to serious environmental degradation without necessarily sharing in much, if any, of the wealth generated by mining.

This dissertation examined the effects of environmental remediation on the heritage and preservation of industrial regions, specifically examining copper smelting in a broader mining landscape, and the complex negotiations undertaken and compromises reached by outside remediaters and inside preservationists as each argued for what they considered was the best course of action. Chapters 1-4 explored the technological and environmental history of copper smelting from its pre-historic origins through the $20^{\text {th }}$ century when American copper mines and smelters dominated world production and the American economy dominated world consumption. Chapters 5-7 focused on three of the most significant $19^{\text {th }}$-century copper mining districts in the United States-the Keweenaw Peninsula of Michigan, the Butte-Anaconda district in Montana, and the Ducktown district in Tennessee — and investigated the conflict between historic preservation and environmental remediation.

The question posed in the introduction of this dissertation asked:

How does a community that desires to preserve and commemorate parts of its history articulate and negotiate that desire in the face of sometimes overwhelming opposition, in this case, from a well-funded organization aimed at remediating the waste streams that emanated from that very same historic landscape when the historic resources in question stand in the way of the simplest and most linear means of remediation? 
The answer required an initial understanding of the economic, demographic, and perception/value systems of the communities being examined. This analysis suggested a predictive model for the experiences of the three districts that could be extrapolated to examine other rural mining and smelting locations facing declining fortunes and increasing concern about the legacy of industry. (See Below) Using the model to compare the Michigan, Tennessee, and Montana districts ultimately contributed to an understanding of the forces that led to the three heritage-remediation compromise landscapes.

\section{Mining District Heritage Model}

Each of the three districts went through four distinct phases: (1) significant growth in the $19^{\text {th }}$ century, (2) periods of high production in the early $20^{\text {th }}$ century, (3) a period of decline that ultimately led to (4) the abandonment of (most) mining and smelting operations by the end of the $20^{\text {th }}$ century. All three also had significant and persistent environmental issues leading to listing on the Superfund National Priorities List (NPL) or, in the case of Ducktown, Tennessee, a negotiated non-listing with all the legal and procedural requirements of a listed site. All three also spawned significant and expanding heritage movements to commemorate their once-proud history—movements that began as the output of each district began to decline.

At each phase — growth, high-production, decline, and abandonment—issues of economics and environment/landscape change had clear implications for the self identity and external perceptions of each region, and many of these issues unfolded along parallel 
lines. These parallel effects suggest a model to illustrate how historic districts deal with both their contaminated pasts and heritage concerns. This short section will explore this model, which may have implications for future studies of historic industrial districts undergoing environmental remediation.

The life span of any extractive industrial district follows a rough bell curve based on the productivity of and income generated from its mines. (See Figure 8.1)

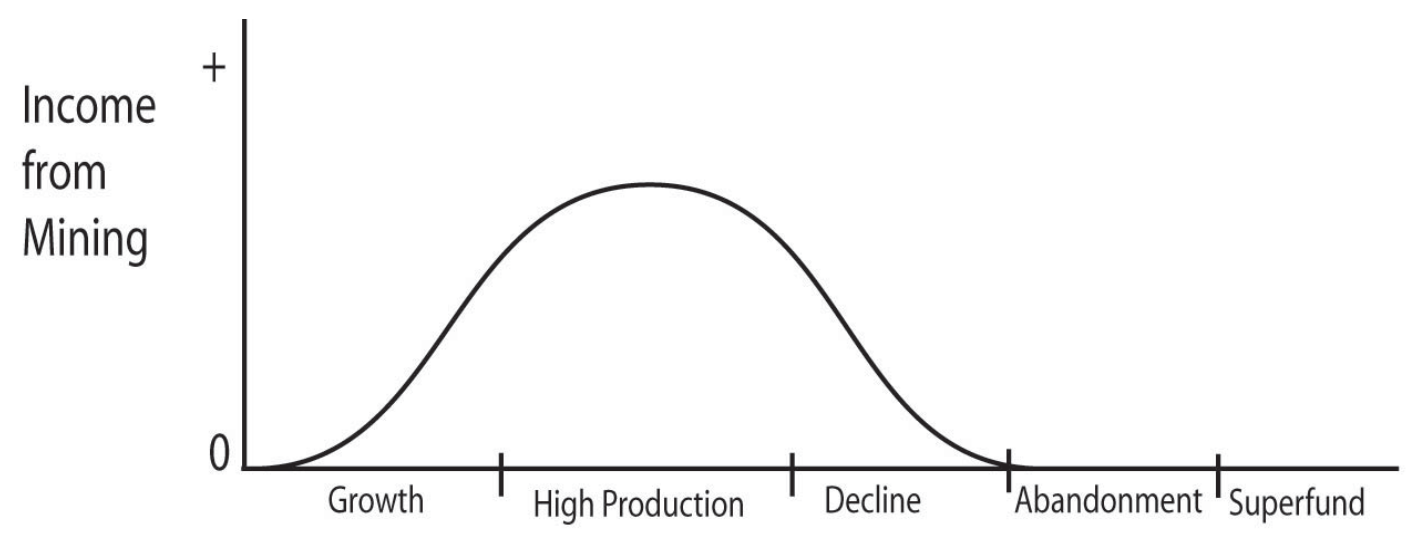

Figure 8.1 Income from Mining, broadly defined and based on productivity, increases through growth and high-production periods then declines as ore quality decreases to a point that mining becomes unprofitable. The growth period in most profitable and long-lived districts, however, is relatively short and steep and the decline is long and slow. (Source: Author)

In most instances, mines have significant growth in their early lives, leading to varied production highs, but as ore quality and quantity dwindle, mining declines. Some districts may have substantial deposits of lower-grade ores that, after the richer early ores are harvested, can prolong life, but these usually require a significant increase in the scale of operations. ${ }^{631}$ Ultimately, however, when the quality of ore gets too low to mine and

\footnotetext{
${ }^{631}$ In reality, mine productivity and profits do not map to simple bell curves, but rather are significantly influenced by the fluctuating demand and price of the commodity, lessening ore quality, and evolving technology in complex and myriad ways leading to many productivity peaks and valleys over the life of the
} 
process profitably, the district's extractive history comes to an end, often leaving behind physical remnants of the once-productive landscape including structures, mining cavities, and mining and processing wastes accumulated over decades of mining efforts under limited or non-existent waste-handling regulations.

Montana copper production, which, for example, did not exist in any significant quantity before 1880 , grew to 100 million pounds per year in 1887 , out producing the reigning Michigan district. By the late mid-1910s, Montana was averaging over 300 million pounds of copper per year before declining back to 100 million pounds in the mid-1940s. Although the Berkeley Pit sustained production in the district until 1982, underground mining came to a halt in the 1960s.

Population size of the districts followed a similar early trajectory to income, but stabilized after mining ended. (See Figure 8.2)

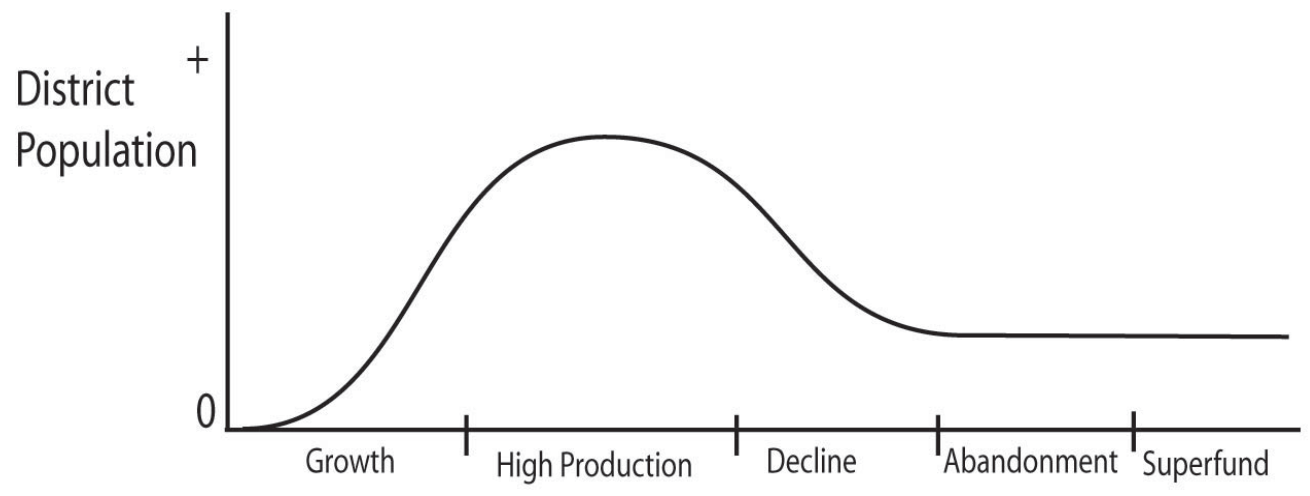

Figure 8.2 District Population of mining and metal processing regions will increase through growth and high-production phases, then as mining declines, many people will leave the area searching for work, ultimately leaving a relatively stagnant population of long-term residents. (Source: Author)

mine. Mining companies, especially in the $20^{\text {th }}$ century, diversified production, opened new ore deposits, and vertically integrated to hedge against declining mine production in any one region. 
In many cases in the United States, new mining deposits were found in rural and isolated areas as geologists ventured west exploring new territories. Often after the removal of indigenous populations, mining and metal processing expanded rapidly during the growth and high-production mining stages with sometimes vast numbers of European and Euro-American settlers moving in and building towns with downtown districts, theaters, saloons, and new housing developments to support and service the burgeoning new populations. However, when mine production slowed leading eventually to operational abandonment, many people, mostly younger, left the regions looking for work. They left behind a much smaller group of people, now many second, third, or fourth generation residents, who considered themselves locals with a birthright to the heritage of the region and a strong affinity for the landscape. They tried to sustain their communities in the face of declining economic conditions. Members of this group were often the initiators and drivers of the first heritage and commemoration projects, and also the key population the EPA was concerned about protecting. Houghton County's population, for example, increased during the region's mining growth period reaching a recorded high in 1910 of 88,098. Following peak production later in the decade, the county's population dropped to 71,930 in 1920 , then to 52,581 in 1930 . By the 1950 s the population reached the mid 30,00s and has remained near 35,000 from 1960-2000. ${ }^{632}$

In the growth and high-production mining phases, regional identity was generally favorable and based on the success of mineral operations and the importance of its mines, their financial returns, and their associated political power. (See Figure 8.3)

\footnotetext{
632 “County Population Census Counts 1900-90.” U.S. Census Bureau, www.census.gov/population/www/censusdata/cencounts/index.html, (accessed August 12, 2009).
} 


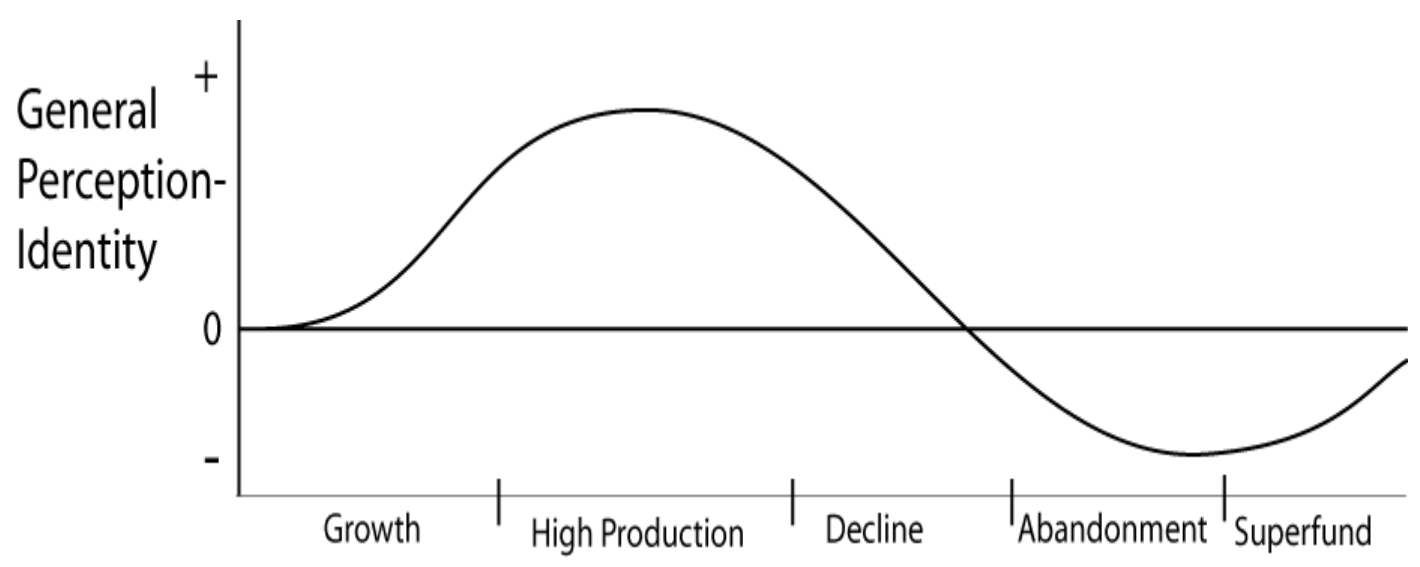

Figure 8.3 General Perceptions and Self Identity of a region are usually favorable as the district is producing wealth, but decline as output slows, incomes drop, and the reality of environmental contamination set in. It will likely rise again as remediation efforts finish and the region is officially delisted from the NPL and heritage projects commemorate the region. (Source: Author)

The region itself, if not the state within which the mines, mills, and smelters resided, sometimes had high average individual incomes and a strong tax base directly derived from mining. The mineral companies themselves often had fairly strong political influence on local and sometimes state and national governments, and were thus able to keep their operations free from many economically distracting influences like foreign competition, waste disposal restrictions, and organized labor. Most local residents in these periods of growth were not really local, but new to the region, lured by the prospect of good-paying jobs and had a larger affiliation with the industry and had favorable views toward the work. $^{633}$ When the Anaconda Copper Mining Company beat Calumet and

\footnotetext{
${ }^{633}$ This argument, however, is not intended to minimize the significant conflicts that erupted in mining districts between mine management and labor over issues of safety, wages, paternalism, and unionization as production increased and then decreased, or to suggest that political conflict did not disrupt the continuous development of certain regions, or that mining companies did not garner substantial and unlawful political control. It merely suggests that mining growth and expansion tended to be viewed broadly as providing positive economic returns. While the identity of a region on a broad scale can be seen as positive with positive growth, often that positive identity is more clearly focused in later phases when the negative
} 
Hecla's attempt to shut down the Montana industry and Butte became the largest copper mining district in the world in 1887 , local newspapers proclaimed the victory. Similarly, during their periods of high production both Michigan and Montana copper districts celebrated their contributions to copper mining proclaiming their world-leading output and the world's largest steam-hoist, smoke-stack, and smelter, and the world's deepest copper mines.

However, as production slows and infrastructure improvements decline, there is less investment in the workforce, often causing strikes over unsafe working conditions, and, with significant environmental decay, local morale and external perception of the once-productive district falls, sometimes to very low levels. Butte and Anaconda's designation as the "ugliest spot in Montana" and one of the "world's must-miss vacation spots," and articles on Tennessee's Copper Basin titled "the Death of Ducktown" and "Copper Basin Cover-up" clearly echo the negative perceptions generated during periods of decline. With positive redevelopment in these regions - both in terms of growing heritage consciousness and remediation of obvious health risks - perceptions of life in the region, both internal and external improve. (See Figure 8.3)

While production increases through the first two mining phases, the landscape changes accordingly, and sometimes at alarming rates often leading to an awareness by some, of growing environmental threats. (See Figure 8.4) The wastes generated by mining operations were only important to the mining companies if they presented a production bottleneck problem, or could at some point in the future be processed for contamination cause reflection on earlier, better times. 


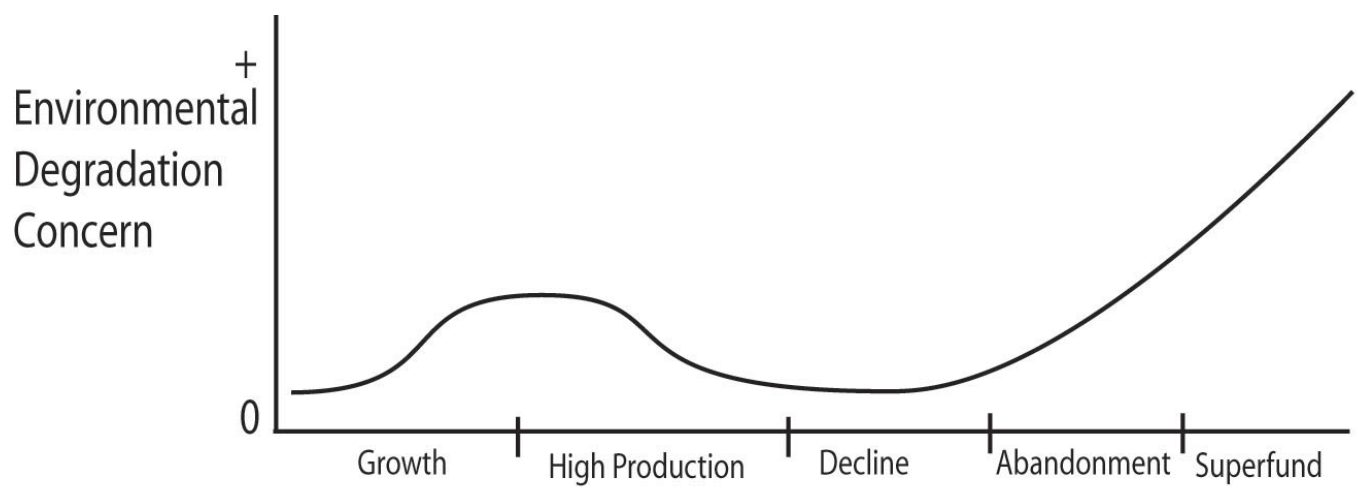

Figure 8.4 Environmental Degradation Concern has only a modest effect on operations in the growth and high-production phase and declines if the mine has enough capital and political influence to buy-out those concerned. However, it increases considerably as mining slows and communities assess the long-term environmental costs of having hosted extractive industries that may no longer provide any economic benefits to the area. However, in some instances, growthperiod pollution did not exist on a large enough scale to warrant early concern like Michigan, while in other districts, the effects of early pollution did not decline, and concern remained high until environmental concern mounted in the abandonment and superfund periods like in Tennessee. (Source: Author)

income-generating by-products or reprocessed for valuable materials lost using earlier, less-efficient concentrating methods. Actual environmental degradation during the first phases, however, was only important to those who were not part of the capitalgenerating-machine or outside of the company influence and being negatively affected. These parties usually had limited recourse except to take the offending industries to court and sue for property damages. In some instances, the offending industry simply paid the damages, acquired the damaged properties, or installed pollution control equipment if the toxic waste had some salable value. These options were often considered a less-costly alternative to fighting court cases even those a mining company would likely win. If the environmental landscape change was significant enough and highly visible, then the problems were written about in newspapers, journals, or textbooks, but little was usually 
done to hamper the income-generating capacity of the industry. Tennessee/Georgia, and Montana farmers and land holders, for example, suffered from the deleterious effects of mining and smelting and took the offending companies to court in the early $20^{\text {th }}$ century. Anaconda successfully handled its pollution problems with settlements, land purchases, and negotiated changes to practice, and, after environmental degradation concern dropped in the early 1930s, could continue operating largely without concern about pollution until the 1970s. While the Keweenaw never saw an early concern for environmental contamination, the Ducktown district never lost the stigma of pollution. After lawsuits forced them to change practices, albeit to new systems that resulted in significantly improved profits, Tennessee copper companies began remediating the landscape and continued to do so in 2009. Its concern never went away, but did increase substantially, like Michigan's and Montana's, as new toxins were identified in the later abandonment and superfund periods.

These early concerns about environmental change formed the roots of later responses to landscape remediation in the districts, especially after mining and processing slow down or are abandoned. Quieted sometimes, but never extinguished, environmental concern grows significantly after mine productivity declines, often following, but not necessarily related to, the establishment of national social-political conservation movements (especially following EPA investigations of sites under Superfund).

In the period of decline, as extractive output slows, people and communities do not earn as much as they did before, workers benefits and jobs are cut, companies do not 
invest in infrastructure or productive improvements as much, and the regional population starts to drop almost as fast as it grew in the early stages. With declining mine output and community wealth, especially noticeable after another mining region surpasses their once-significant productive capacity, communities' identities start to change, and second, third, and fourth generation locals begin to notice how much money has left the region, and how much they will soon have to contend with rising unemployment, a declining tax base, declining property values, an aging population, and the environmental and health impacts left behind. With declining tax income and lessening corporate support for community projects, towns start looking shabbier as structures are torn down, burned down, or just abandoned and left to deteriorate, affecting the self identity and external perception of the region. (See Figure 8.3)

Blame is hard to assign by these communities unless a "new" corporate entity, such as a petroleum company, can be targeted for causing much of the economic decline and contamination, like in Montana. But, in other instances, the new corporate entity may be seen as the savior fixing the problems to the landscape that no-one in particular is to blame for, such as in Tennessee. In other instances, the communities tacitly blame the U.S. Government for its wanton disregard for the region's well-being during the industrial decline and the instigation negative changes in public opinion after the EPA declares an area contaminated and in need of significant cleanup. The government, in turn, often desperately searches for someone to blame (pay) for the environmental problems, especially if there are acute threats to human health and expensive remediation alternatives. 
Despite varying degrees of culpability among stakeholders, this is also the time that locals start thinking back to their times of prosperity (the "golden age") independently and begin commemorating their past, like all three districts in this study, with small heritage projects like museums, National Register nominations, and interpretive/educational programs in an attempt to hold on to or regain some bit of the dignity lost with the decline. (See Figure 8.5)

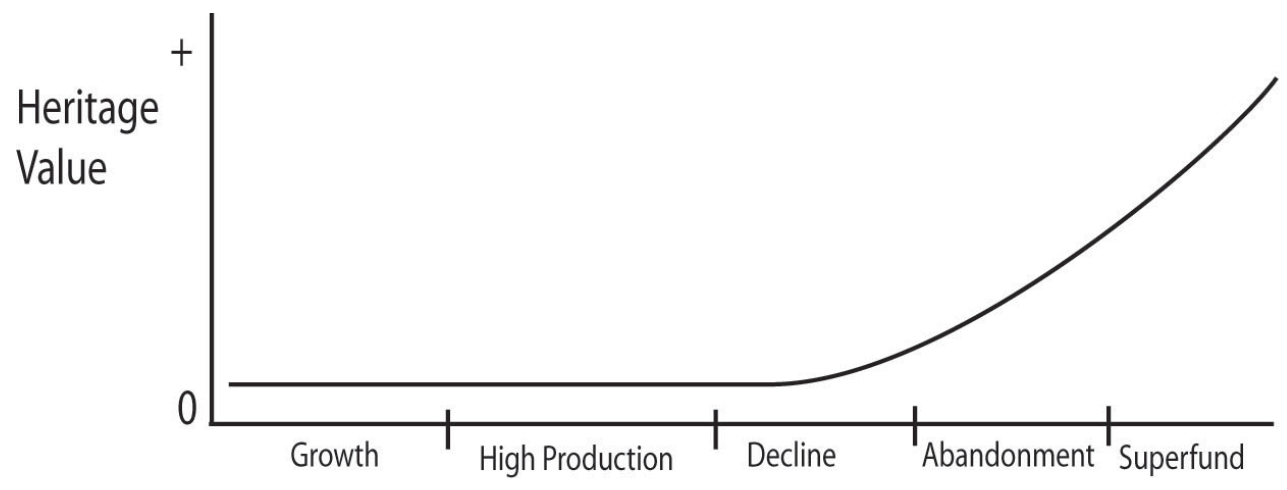

Figure 8.5 Heritage Values of a region, or the concern for commemorating the past, begin to grow as industries decline. Residents look to commemorate their once-glorious past as a means of retaining self-respect and generating tourism and economic development opportunities. Value and perception of the landscape become much more important as mining and mining income dwindle in the decline phase.

Like the early concern for environmental degradation, these early heritage projects often serve as the roots for later heritage projects, especially after Superfund statues allocate funding beyond remediation and other federal laws mandate consideration of the effects of all federal projects on cultural resources. Both early heritage concerns and early environmental concerns reflect the desires of the community, but each needs a powerful 
agent of change like Superfund to really awaken and drive the formalization of localized planning.

In the 1960s, genuine and mounting concern about the health effects of the more invisible toxins generated by industry grew following new studies on hazardous wastes and human health. This concern contributed to a growing social-political movement against environmental degradation and led Congress to enact its first statues regulating industrial effluent levels. In the ensuing decades, Congress passed specific laws limiting air pollution, limiting water pollution, regulating transportation and disposal of hazardous wastes, and regulating the cleanup of abandoned hazardous waste. Most of these new laws were enacted after a century of American industrial dominance had left significant scars on the landscape and other nations, with lower production costs and weaker environmental laws, came to dominate global mineral production.

Near the end of production in a mining district, the environmental effects of the once former grand industry seem much more pronounced because they are no longer part of an income-generating productive process, and popular opinion turns decidedly antagonistic. Community identity is nearly at its all-time low as locals feel abandoned and contaminated by the industry that once gave their community purpose. Almost worse, governmental outsiders judge the town's environmental problems as a result of the new environmental laws. If they decide it needs significant Federal effort to remediate, the decision often undermines hopes of new tourism-based development. By now the region has been completely cleared of its mineral wealth, the community's tax base is 
gone, many of the jobs/people are gone too, and all that remains are the toxic residues and the negative association of being declared a Superfund site. (See Figure 8.3)

External judgment and the remediation process present conflicting alternatives to communities. While a Superfund project in a town reflects the acknowledgment of and remedy to past sins leading, hopefully, to a "clean bill of health" and a readiness to redevelop damaged lands, the very same clean up announces to the world that this place is contaminated and not suitable for immediate redevelopment. Tourism in many ways fits nicely into this scenario, because people visit the region for a short time, not long enough to be contaminated, but long enough to inject money into the local economy. Ironically, remediation efforts often spur historic preservation and heritage awareness because they threaten to destroy remaining potential sources of pride and revenue.

At this point preserving and promoting heritage become increasingly effective because parts of the clean-up legislation allow for cultural improvement. However, many of the clean-up professionals and managers, without the sense of identity shared by the locals, are mostly interested in fixing the threats to human health and the environment, not heritage preservation. The first and often least expensive remediation considerations are often to demolish standing features, and grade and cover contamination—even historically significant structures — often causing heritage-minded locals, but not necessarily development-minded locals, to sense the impending loss of their heritage landscape and identity more acutely. (See Figure 8.5) 


\section{Landscapes}

Copper mining and smelting in Montana, Tennessee, and Michigan left important legacies for later generations described by the model above and Table 8.1 below.

Table 8.1 Legacy and Reaction

\begin{tabular}{|c|c|c|c|}
\hline & Michigan & Tennessee & Montana \\
\hline Primary Ore Type & Native & Sulfide & Sulfide \\
\hline $\begin{array}{l}\text { Copper Mining and } \\
\text { Smelting Operations }\end{array}$ & 1844-1969 & 1854-1987 & $1880-1980$ \\
\hline Superfund Listing & 1986 & 2001 & 1983 \\
\hline $\begin{array}{l}\text { Contamination Threat } \\
\text { to Human Health }\end{array}$ & Low & High & High \\
\hline $\begin{array}{l}\text { Key Environmental } \\
\text { Problem }\end{array}$ & Mill Tailings & $\begin{array}{l}\text { Acid Production, } \\
\text { Smelter Effluent }\end{array}$ & $\begin{array}{l}\text { Mill Tailings, } \\
\text { Smelter Effluent }\end{array}$ \\
\hline $\begin{array}{l}\text { Expected Cost of } \\
\text { Cleanup }\end{array}$ & $\begin{array}{l}\$ 15,000,000 \\
\text { (fifteen million) }\end{array}$ & $\begin{array}{l}\$ 100,000,000 \mathrm{~s} \\
\text { (hundreds of } \\
\text { millions) }\end{array}$ & $\begin{array}{l}\$ 1,000,000,000 \\
\text { (one billion) }\end{array}$ \\
\hline Cleanup Funder & EPA-"Super-Fund" & $\begin{array}{l}\text { Occidental } \\
\text { Petroleum }\end{array}$ & ARCO (BP) \\
\hline $\begin{array}{l}\text { Post mining Economic } \\
\text { Recovery }\end{array}$ & $\begin{array}{l}\text { Heritage, University, } \\
\text { Continued Industry }\end{array}$ & $\begin{array}{l}\text { Heritage, U.S. } \\
\text { Government }\end{array}$ & $\begin{array}{l}\text { Heritage, Univ., } \\
\text { Continued } \\
\text { Industry }\end{array}$ \\
\hline Heritage Priority & High & High & High \\
\hline Heritage Planning & $\begin{array}{l}\text { NPS-Community- } \\
\text { NHL-HAER }\end{array}$ & $\begin{array}{l}\text { Cleanup Co.-EPA- } \\
\text { NR }\end{array}$ & $\begin{array}{l}\text { Community- } \\
\text { NHL-HAER }\end{array}$ \\
\hline Community Size & Medium & Small & Medium \\
\hline Earliest Museum & $1920 \mathrm{~s} / 1958$ & 1977 & 1963 \\
\hline Heritage Success? & High & Medium & High \\
\hline
\end{tabular}

All three mining districts were developed on important ore lodes, in stunning mountainous or hilly surroundings, near rich waterways and thick woods. All three developed or adapted technologies and social structures to overcome the challenges of the natural landscape and wrest copper from the local rock. These actions ultimately elevated two of the districts to the top copper-producing-district in the world, and the 
third to national importance, and created landscapes that some locals perceived as heroic. Those same forces that created the heroic landscape, however, also significantly degraded the environment. The combination of mining decline, economic decline, blight, and loss of prestige with the need to clean up past egregious behavior and the stigma of Superfund led to an ethos of defeat.

Both historic mining and environmental degradation legacies led to important decisions regarding these opposing community needs. On the one side, the desire to commemorate the once significant and heroic past and lure visitors to their region drove locals to preserve historic buildings and landscapes, develop museums, and try to recapture some of the district's former glory and character. The value of the tourism market, which had become the second or third leading industry in each state by the 1950s, was not lost on local heritage planners in the economically declining mining regions. On the other hand, the desire to clean up the region and eliminate the stigma of sometimes very serious contamination drove efforts to remediate the landscape as thoroughly as possible and move on to redevelopment projects not necessarily directed at short-term visitors, but instead aimed toward creating investment opportunities for the people who already lived there or luring long-term investments from outside the region. Negotiating a resolution between these two competing legacies, represented in principal by the National Historic Preservation Act (NHPA) and the Comprehensive Environmental Response, Compensation, and Liability Act (CERCLA), ultimately created the landscape of compromise. 
The heroic landscape of the Butte-Anaconda district reflected its large scale. Sitting in a towering and beautiful mountain-scape at the Continental Divide, the onetime largest non-ferrous mining corporation in the world built the largest smelter complex and tallest smelter stack. Although Michigan mining and smelting structures were built on a smaller scale, it sat in a region of arguably equal beauty. Its one-time worlddominant copper production began with the first large-scale mining boom in the United States, was dispersed over a 100 -mile three-county mineral range, produced $82 \%$ of the nation's copper at one time, and had some of the world's deepest hard-rock mines. While Tennessee's copper production never rivaled Michigan's or Montana's, it created, although does not celebrate, the largest sulfuric-acid-making plant in the world and perfected nearly fuel-free pyritic smelting. To the residents who live there, however, the heroic landscape (barren and treeless) reflected a very long-lived and prosperous industry.

The early landscapes of defeat in Montana and Tennessee reflected mostly the pollution residue from processing and smelting sulfide ores which had created significant and early smelter smoke problems and led to important lawsuits against the mining companies. Although the Anaconda Copper Mining Company resolved many of the legal challenges to its operations by 1933, the Tennessee Copper Company (TCC) and Ducktown Copper Sulfur and Iron Company (which TCC bought in 1936) were, in the 1930 s, just coming to terms with the scale of vegetation loss and erosion left by $19^{\text {th }}$ century smelting operations. Although Anaconda (as an ARCO subsidiary) would eventually use the cost of compliance with pollution regulations to justify closing its 
expensive and out-dated Washoe smelter in 1980, it had largely operated without significant concerns about environmental litigation from the 1930s until EPA came in under Superfund in the 1980s. The Tennessee Copper Company, or one of its later corporate incarnations, on the other hand, would work with federal and state agencies for 75 years to remedy the pollution-generated denuded landscape before it too faced larger remediation issues under Superfund in the 1990s, reflecting a very different experience with federal agencies than Montana or Michigan.

The Michigan landscape, however, never suffered from significant environmental problems in its early phase. It generated coal-smoke, denuded some of the surrounding forests for mining needs, and dumped its tailings into waterways, but its mines were so spread out in the district that timber was never that far away, and its major $20^{\text {th }}$ century mills, more centrally located in Houghton County, simply moved to nearby locales on larger or non-navigable streams or lakes when the Army Corps of Engineers complained that their mill wastes interfered with navigation.

The more serious landscape of defeat for all three districts occurred during the declining or post-mining periods after most metals processing had ended and concern about contamination swelled. Tailings in Montana after a century of mining were heavily contaminated with a variety of carcinogenic materials including heavy metals, arsenic, and processing chemicals. Tailings, often dumped directly into nearby streams, were washed up to 125 miles down the Clark Fork during spring floods, littering and contaminating its entire length from Butte to impoundment dams in Milltown. Further, arsenic dust from smelting was distributed through smoke and settled on soils and in 
homes creating especially dangerous conditions near smelter stacks. Acidic waters drained from the mines, and chemical residues from mining and smelting, slag, and ash were all dumped on or indiscriminately disbursed into the landscape creating groundwater and air contamination. All of these conditions led to the largest Superfund site in the country, and one of the costliest.

Building- and community-loss furthered the sense of defeat in the ButteAnaconda landscape. Significant loses began with the opening of the Berkeley Pit in 1952, and continued in the 1970s with the threat of pit expansion, the rash of arsons, and general neglect. Exacerbating these loses were the growing complexity and cost of the Superfund project, beginning in the 1980s. EPA planners often considered (contaminated) building demolition a cheaper alternative to remediation and preservation as at the Washoe Smelter in Anaconda. Exacerbating these conditions were highly visible events such as the relocation of Mill Creek residents in 1986 and the death of 342 snow geese in 1995 .

Tennessee was also forced to deal with significant contamination including large lead accumulations from its several acid plants, slag and ash dumps near former smelting sites, chemical spills, acid mine drainage, and heavy metal- and chemical-laden sediments that washed into the Tennessee River watershed from major erosion. Further, the smoke-denuded moonscape in the middle of heavily-wooded East Tennessee became a national, if not international spectacle after a two-page photo spread appeared in National Geographic Magazine in June, 1973. Adding to the defeat, several of the district's underground mines collapsed creating areas that were (and are) inaccessible to 
people, and even the community's effort to preserve a small portion of the denuded landscape behind the museum failed.

While Glenn Springs Holdings (GSH), the environmental arm of the responsible party in Tennessee, negotiated to keep the EPA from listing Ducktown on the National Priorities List (NPL) to avoid, it claimed, the stigma of Superfund-association, it agreed to fund the cleanup as outlined in the Memorandum of Understanding (MOU) signed by EPA, Glenn Springs, and the State of Tennessee. Further, to stay off the NPL, GSH was required to follow the same public-involvement, remedial investigation, work-planning, execution, and EPA- oversight procedures as if the site had been listed. Despite the success of staying clear of the NPL, the region continued to carry the stigma of a distressed and degraded landscape because of persistent imagery, public involvement, and the on-going EPA-guided cleanup.

Nonetheless, the cleanup remained privately funded and privately managed on private land, and, although Glenn Springs publically promoted its efforts to remediate the area and contributed to numerous community projects, it was still a private project and not required to abide by Section 106 of the National Historic Preservation Act as interpreted by the EPA, Tennessee SHPO, and GSH. Over the entire process from the cessation of mining, Ducktown, like Butte-Anaconda, lost much of its structural character, not only due to economic decline and neglect, but also to cleanup decisions that selected less expensive remediation alternatives to preservation.

Michigan, on the other hand, never suffered heavily from environmental problems or stigmas. The district, because of its age and disbursed mining locations, lost many of 
its structures to neglect, abandonment, or redevelopment as mining and economic centers moved closer to Houghton over 100 years. Despite this loss, the abandonment of places, in some ways, led to the growth of early heritage tourism and the exploration of ghost towns. The biggest problem the EPA identified in Michigan under Superfund was copper and heavy metal-contaminated stamp sands that only posed a human health threat if the sands were going to be redeveloped into residential property, otherwise the sands were considered less critical environmental threats. The EPA covered the tailings with a soil and vegetative cap, a preventable loss to some in the district who considered the tailings an important and largely benign historic feature of the landscape.

In all three districts, many of the environmental remedies simply erased character and identity. In Montana and Michigan, re-graded landscapes and smoothed out bumps designed to keep new soil intact while non-native grasses grew left a muted and somewhat subdued, or even boring landscape. The revegetation efforts in Tennessee were limited to the few tree and grass species that could tolerate the contamination, leading to significant lack of biodiversity in the "new" woods that feel more like a tree farm than a forest.

\section{Landscapes of Compromise}

In all three of the districts the two opposing schools of landscape restoration were represented by those that wanted the landscape's natural beauty and cleanliness restored (to acceptable levels) so they could get back to the business of economic redevelopment, and those that wanted historic landscape features preserved or restored to celebrate the 
past and revitalize the declining economy through tourism. However, the three regions did not hold onto their historic character equally. An important key to successful preservation negotiation was often the size and diversity of the preservation-minded population and their successful arguments against certain types of remediation alternatives.

Similarities existed among the districts. Both Montana and Tennessee had large petroleum companies ultimately take responsibility for the remediation, spending from hundreds of millions of dollars to one billion dollars, some of which went to preservation projects in both districts. Both had significant air pollution problems from sulfur smoke disbursed over a wide area and significant tailings or water runoff problems affecting rivers that spread their contaminants downstream. Both had air and water problems that affected areas far away from the mining district. Both had large, post-mining contaminant disposal problems and highly visible landscape degradation. Both the Tennessee Copper Company and Anaconda operated demonstration farms in the $20^{\text {th }}$ century in a vain attempt to prove there was no contamination.

Michigan and Butte shared different characteristics. Both regions led worldproduction at one point. Both had relatively large populations and diverse heritage planning communities augmented by new arrivals to the region. Both had state technological universities in the mining district. Both had significant heritage projects leading to National Historic Landmark designations and HAER documentations. Tennessee and Michigan each had early mining histories impacted by the Civil War, were 
in naturally beautiful areas, and wished to celebrate their pasts, but little else relevant in common for this dissertation.

Where Ducktown had a relatively small, stable, population of long-time residents, Butte-Anaconda had a larger population with influxes of new people at various times related to new government programs in the 1970s and the presence of Montana Tech. Butte also had a major interstate and airport that easily brought people into and through town. Its larger population allowed Butte to generate several special interest groups focused on preservation. Many of its new residents were educated, and some even had interests in the preservation of industrial remains. These outsiders came to Butte-Anaconda with something to contrast it to as well. Few people came from a region with a Berkeley Pit, gallows frames dominating a hillside, a structure like the Anaconda Stack, or a Superfund site as large, and the new residents evaluated the landscape as it stood when they arrived, not how it used to be.

The special interest groups and preservation-minded newcomers augmented a preservation movement begun by locals in the 1950s. Together, they generated National Historic Landmark nominations, created a museum, started an archive, and passed several local preservation ordinances that included historic mining and industrial features. They pursued many projects and, with knowledge of preservation law and well-organized efforts, were able to exert political pressure, articulate preservation desires, and negotiate long-term plans to confront the pending loss of cultural resources and historic landscapes by Superfund projects. Even the State Historic Preservation Office ceded control over Section 106 issues to the local counties (to insure speedy resolution of issues generated 
by the cleanup). Overall, the Butte-Anaconda district preservation population was the most organized, bottom-up oriented, and successful of the three.

Although Butte-Anaconda, and by extension Milltown, had the largest Superfund site, in some ways it was the also best set up to negotiate and promote heritage, or to corrupt a concept from M- L. Quinn cited in Chapter 5, the region had heritagesusceptibility. With a sizeable population of educated, preservation-oriented, and planning-minded people aware of the law, an established National Historic Landmark district, maybe even a bit of historic activism left in the once heavy-unionized community, and a very wealthy, but not necessarily cooperative, responsible party with a desire to end the expensive cleanup as soon as it could, heritage compromises were frank and decisive. Further, the district was successful in getting National Park Service recognition through the HAER project and successive National Historic Landmark district expansions, although unsuccessful at getting a national historical park in ButteAnaconda. Whether or not a formal unit of the National Park focused on historic mining and smelting would ultimately have helped the active heritage community or complicated negotiations, in the long-run, the Butte-Anaconda community was able to define what it wanted and how it wanted it, and negotiate/compromise to get much of it.

One of the key factors influencing the Ducktown heritage process, on the other hand, was a heavy EPA and corporate presence that largely overshadowed the local preservation population, which was relatively small. Although both the EPA and Glenn Springs Holdings (GSH) considered and interacted with the locals, many of whom were not dissatisfied with GSH, the company largely drove both the remediation process and 
heritage process, making heritage decisions with limited public consultation. Further, the population of the region, many of whom wanted heritage and the 30 -acre denuded landscape behind the museum preserved, was small. While the small size of the population ultimately made it easier for Glenn Springs to make effective community contributions and generate local support, the population was not large or diverse enough to generate planning committees to oppose certain heritage decisions or even lobby for different actions. Often the cleanup company talked to the same group about remediation, as mandated by the MOU, as it did about heritage issues. Further the Ducktown Basin Museum, the key heritage organization in the area, was too underfunded and understaffed to really push for a strong heritage plan it would have to administer in the long-run. Despite some well intentioned GSH- and EPA-managed heritage projects in the overall work plan, these conditions ultimately led to a relatively weak voice for preservation that was further worsened by the inapplicability of Section 106. In many ways this was the most top-down planning of the three districts. Moreover, heritage decisions were being made largely by the remediation experts, not heritage experts.

The key difference between the Michigan cleanup and the Ducktown and ButteAnaconda cleanups was its simplicity. Michigan's Superfund project dealt mainly with tailings dumped in and exposed in Torch Lake, Portage Lake, and Lake Superior. Outside of relatively minor removal of contaminated wastes and storage containers, the project mostly simply graded, capped, and covered exposed tailings at 10 of the 13 locations. This relatively small area and relatively simple work resulted in a comparatively inexpensive cleanup compared to the other two and also likely influenced 
EPA's withdraw of its normally aggressive pursuit of potentially responsible parties. Although the project was federally funded and managed making Section 106 applicable, only one of the sites, the Quincy Smelter, had properties determined eligible for the National Register.

The Michigan Copper Country, like Butte-Anaconda, had a fairly stable population and a means of drawing new people in through a local university that had an active program dedicated to industrial heritage that sponsored heritage research throughout the region. Further, after 1992 the new Keweenaw National Historical Park (KNHP) brought in additional educated historians and historic architects to work with the 19 formal community-partner sites and many other related sites, and also completed regional management planning documents and cultural landscape reports that supported the NPS mission. In addition, unlike the other regions, the Keweenaw had a well established patron in the U.S. Senate who actively pursued funding earmarks for heritage projects, including the smelter. So in many ways, Michigan's landscape diversity extended to its preservation community too. With similar community groups as Butte, Michigan's Copper Country hosted a relatively large cadre of professional heritage practitioners. Michigan copper heritage, as opposed to Montana and Tennessee, however, had neither a strictly bottom-up nor top-down approach to heritage management.

Of the three sites, Michigan had the simplest heritage conflict with Superfund but also the least amount of money available for alternate projects like preservation. Although the remediation plan seemed simple, EPA both encouraged preservation by 
recognizing the importance of the smelter (which also simplified its workload and final costs), but also complicated preservation when it attempted to extract money from NPS to pay for asbestos removal at the site, forcing the most active heritage professionals away from the project for nearly two years.

In the long-run, however, EPA worked to find compromise solutions to remediation issues at the Quincy Smelter to appease environmental concerns generated by the State of Michigan, while respecting the heritage of the site to appease the NPS, Sections 106 and 110 of the National Historic Preservation Act, and many members of the community. In the long run, however, copper mining and smelting heritage in Michigan was not affected very much by Superfund. EPA focused on stamp sands, but not all of them, and Michigan's other historic copper mining resources were spread out over a wide area, most of which EPA was not interested in, so preservation had to do much more with combating neglect and inappropriate redevelopment than anything else, which is ultimately part of the KNHP's mission. This is not to argue that all sites in the region need preservation either, which is not only not necessary, but impossible.

In the end, all three regions successfully commemorated their pasts with museums, historic sites, and National Register nominations, but they were not equal in how their heritage was expressed in their landscapes. The two larger districts, with more significant production, elevated their sites to National Historic Landmark Districts and welcomed HAER documentation projects. All three districts had interpretive signage explaining historic processes that gave their districts significance, but Ducktown and Montana, home to more significant environmental damage and cleanup, interpreted the 
desecration of the environment caused by mining and the near-heroic efforts to remediate it alongside the technological and social histories. Part of the success in Michigan and Montana has to reside with the influx of newcomers interested in the landscape. While many people involved in preservation in both communities were local, newcomers brought a perception of the landscape not compromised by loss and defeat and helped coalesce local heritage preservation into a movement.

On the other side of the negotiation, EPA's mission to protect human health and the environment drove its activities and defined how it approached other, less missiondirect activities. In superfund projects, EPA project managers, often from district headquarters far-removed from the region, approached an NPL-listed site to find a quick "fix" for the problem of contamination without the attachment or regional identity of a local resident. While this detachment may make remediation decisions simpler and appear less biased, it also meant that managers who participated in heritage decisions were missing an important heritage value associated with local identity.

EPA managers understand that the community must be involved and that the EPA must consider residents' opinions and factor those opinions into remediation, especially since there are and will always be multiple ways to approach and negotiate remediation remedies. They also understand that heritage concerns must be addressed if raised. It is in this dialog that most heritage decisions are discussed and the more forceful the heritage voice, the more preservation is considered.

While in general its mission drives EPA's activities and decisions, and the agency does not have a strong culture of heritage-protection, some individual EPA managers at 
least respect a community's desire for heritage even if they don't share it. In both Tennessee, where the EPA manager came from Atlanta and actively participated in heritage decisions with the Glenn Springs project manager, and Michigan, where EPA planners from the beginning considered the Quincy Smelter an important historic resource, individual EPA managers demonstrated compassion for, and at times even enthusiasm for some preservation, but they do not share the understanding of a professional heritage planner or even a heritage-oriented community member.

The Butte-Anaconda district, however, was different. Because of its size, the EPA staff contingent was spread from local offices in Butte and Anaconda, to a regional office in Helena, Montana, to the District office in Denver, Colorado. Because of the size of the project, the EPA also hired local people to run the local offices, and those with a regional association and identity with the landscape, identified with the strong local heritage community, and although they were still EPA mission-driven, they were able to soften the negotiations.

\section{Resolving a heritage-remediation conflict.}

As we have seen, because of different historical, demographic, economic, geographical, and political circumstances, heritage-remediation conflicts were resolved in varying manners in the Michigan, Tennessee, and Montana copper districts, and heritage proponents enjoyed varying degrees of success. What then are the most basic lessons that we can take away from this in-depth study of heritage-remediation conflicts in the three nationally important copper mining and smelting districts; and, in the face of often 
aggressive remediation and development efforts, what steps can those who wish to preserve the heritage of industry in their regions take to insure maximum preservation? Based on our three case studies, there are four keys to success in promoting heritage in the face of large, environmental remediation projects: organization, knowledge, persistence, and political sympathy or support from key state agencies or political patrons in Congress.

Organization is the first key. As our three case studies have shown, the better the preservation elements in a community are organized, the stronger their message and political influence becomes, ultimately resulting in a social-force that must be confronted much more formally by remediation-minded authorities than a small group or individuals would be. The successful organization of grass-roots groups in Butte-Anaconda illustrates this directly and the affiliated heritage partners of the Keweenaw National Historical Park, a large, even loosely, coordinated group, have provided the old Michigan copper district with preservation advocates capable of encouraging remediation and development advocates to negotiate and compromise on heritage issues rather than simply bulldoze everything in its way.

Second, knowledge of the Comprehensive Environmental Response, Compensation, and Liability Act (CERCLA) a.k.a. "Superfund" or other environmental statutes is critical. The laws normally used to initiate and coordinate environmental remediation specifically state that project planners must consult with local communities and consider other relevant legislation, such as the National Historic Preservation Act (NHPA) and other preservation laws. This knowledge allows an organized group to 
make strong legal arguments because neither CERCLA nor NHPA refutes the other, and on-site conflicts usually arise out of the inconsistent interpretation of standards outlined in the laws or ignorance of their intended aims. Further, knowledge of successful alternative approaches to similar remediation problems gives decision-makers more options, like the example of the Old Works Golf Course slag-based sand traps in Montana. Knowledge that smelter slag was being safely used in direct contact with golfers was cited by heritage advocates in Michigan to influence slag-heap preservation at the Quincy site. Of course, recruiting a local attorney interested in heritage preservation to work, hopefully gratis, with local heritage proponents would also contribute to the local knowledge base on legal issues and recourses.

Third, hedging against heritage loss requires persistence. Butte-Anaconda and the Keweenaw each pursued heritage planning over decades. Butte's first heritage plan began in the 1950s, and continued with successive plans and expanded plans in the 1960s, 1970s, 1980s, 1990s, and its latest plan and National Historic Landmark district designation were finalized in 2005. The Keweenaw, too, started with preservation projects in the 1950s and, in 2009, was working on its latest National Park Servicesponsored regional cultural management plan.

Lastly, heritage preservation and environmental remediation are both, ultimately, political in nature. Recognition of this fact and taking the appropriate steps to gain political support can be critical to the level of success heritage proponents can secure in preservation-remediation conflicts. Of course, the previous keys--organization, knowledge, and persistence--can contribute significantly to the ability of local heritage 
advocates to secure such political support too. At the state level, securing the active support of key state agencies, especially the State Historic Preservation Office (SHPO), the agency specifically charged by the NHPA with oversight of cultural resources, can lend significant negotiating weight to heritage proponents in conflict with remediation agencies. For example, in Butte-Anaconda, the Montana SHPO enhanced local heritage planning and preservation efforts, while the weak involvement of the Tennessee SHPO all but sealed the fate of important cultural resources there. At the national level, too, securing political patronage or support is important, especially since the primary remediating agency — the Environmental Protection Agency (EPA)—is federal. A political patron at the national level can help reign in an overly-aggressive EPA, secure funding to enhance heritage preservation, or help secure formal national-level recognition of "historical significance," such as Michigan Senators did in the formation of the Keweenaw National Park and identifying earmarks for the Quincy Smelter, and Montana's senators did in the establishment of high-tech projects in Butte.

All four of the keys outlined above — organization, knowledge, persistence, and political support—are important. Together, they give heritage proponents significant clout and encourage remediation authorities to seek compromise, because, in the long run, compromises are cheaper than prolonged debates and court battles. 


\section{BIBLIOGRAPHY}

Audio Visual Sources

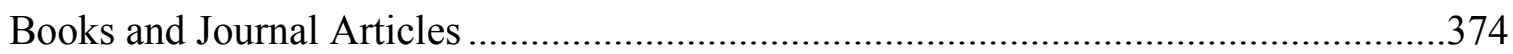

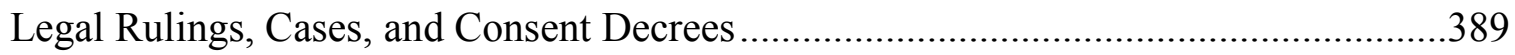

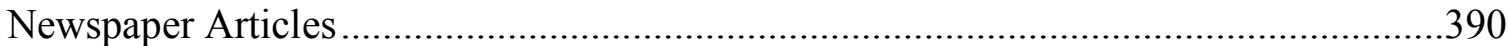

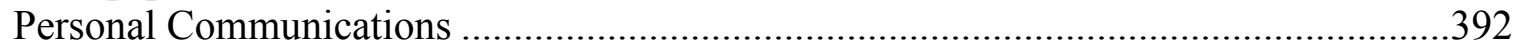

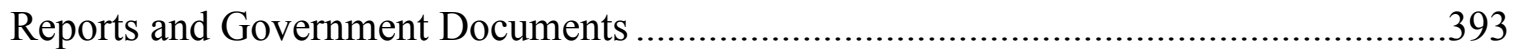

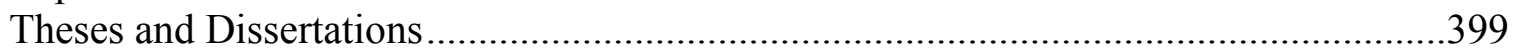

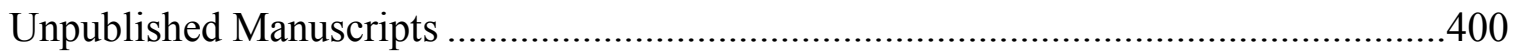

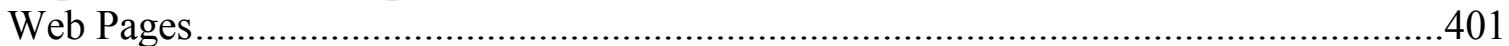

\section{Audio Visual Sources}

Copper Basin Pictorial Calendar. Ducktown, Tenn.: Copper Duck Press, 2008.

Mining the Berkeley Pit 1955-1982. (Interpretive Sign.) Butte, Mont.: Butte Chamber of Commerce, 2004 (est.).

Old Works Vision to Reality. (VHS video.) Butte, Mont.: ARCO Environmental Remediation, 1998 (est.).

A Story of Rebirth. (Interpretive Sign.) Butte, Mont.: ARCO, 2004 (est.).

\section{Books and Journal Articles}

Agricola, Georgius. De Re Metallica. Translated by Herbert Hoover. New York: Dover Publications, 1950.

Aiken, Katherine. "Western Smelters and the Problem of Smelter Smoke." In Northwest Lands, Northwest Peoples : Readings in Environmental History, edited by Dale Goble and Paul W. Hirt, Seattle: University of Washington Press, 1999.

"Anaconda Copper Smelter May Switch to Coal." Chemical Week 123, (1980): 61.

Bacha, Charles P., Joseph L. Schwalje, and Anthony J. Del Mastro. Elements of Engineering Materials. New York: Harper and Brothers, 1957.

Bakken, Gordon Morris. "Montana, Anaconda, and the Price of Pollution." The Historian 69, no. 1 (2007): 36-48.

Barclay, Robert Edward. The Copper Basin, 1890 to 1963. Knoxville, Tenn.: R. E. Barclay, 1975. 
- Ducktown Back in Raht's Time. Chapel Hill,: The University of North Carolina Press, 1946.

Barnhardt, Wilton. "The Death of Ducktown." Discover 8 (1987): 35-42.

Bass, George F. "The Cape Gelidonya Wreck: Preliminary Report." American Journal of Archaeology 65 (1961): 267-76.

Baum, Dan. "Butte, America-Poisoned, Ruined and Self-Cannibalized." American Heritage Magazine 48, no. 2 (1997): 57-67.

Baum, Dan, and Margaret L. Knox. "We Want People Who Have a Problem with Mine Wastes to Think of Butte." Smithsonian 23, no. 8 (1992): 46-55.

Biringuccio, Vannoccio. The Pirotechnia of Vannoccio Biringuccio. Cambridge, Mass.: M.I.T. Press, 1966.

Biswas, A. K., and W. G. Davenport. Extractive Metallurgy of Copper. New York: Pergamon Press, 1980.

Brady, George S., and Henry R. Clauser. Materials Handbook. New York: McGrawHill, 1986.

Bray, John Leighton. Non-Ferrous Production Metallurgy. 2d ed. New York: J. Wiley and Sons, 1953.

Bridges, E. M. Healing the Scars: Derelict Land in Wales. Swansea, Wales, 1988.

Burt, Roger. "The International Diffusion of Technology in the Early Modern Period: The Case of the British Non-Ferrous Mining Industry." Economic History Review, New Series 44, no. 2 (1991): 249-71.

—. "The Transformation of the Non-Ferrous Metals Industries in the Seventeenth Century and Eighteenth Centuries." Economic History Review, New Series 48, no. 1 (1995): 23-45.

Butts, Allison. Copper: The Science and Technology of the Metal, Its Alloys, and Compounds. New York: Hafner Publishing, 1970.

Campbell, Gary A. "A Retrospect of U.S. Oil Industry Takeovers of U.S. Copper Companies." Materials and Society 15, no. 2 (1991): 89-107.

Chaput, Donald. The Cliff; America's First Great Copper Mine. Kalamazoo, Mich.: 
Sequoia Press, 1971.

Childe, V. Gordon. "The Danube Thoroughfare and the Beginning of Civilization in Europe." Antiquity 1, no. 1 (1927): 79-91.

Christensen, Charles. "History of Converting." The Mining World 33 (1910): 103739.

Clay, Grady. "Copper Basin Cover-Up." Landscape Architecture 73, no. 4 (1983): 49-55, 94.

Cloverland Tourist Guide. Menomonee, Michigan: The Herald-Leader Company, 1926.

Coghlan, H. H. "Some Experiments on the Origin of Early Copper." Man 39, no. July (1939): 106-108.

Conant, Henry D. "Copper Smelting in Michigan." The School of Mines Quarterly 42, no. 4 (1911): 285-97.

_. "Copper-Smelting Practice in Lake Superior Region." Mining and Engineering World 35 (1911): 294-296.

_ . "The Historical Development of Smelting and Refining Native Copper." Mining Congress Journal 17 (1931): 531-32.

Cooper, James B. "Historical Sketch of Smelting and Refining Lake Copper." Proceedings of the Lake Superior Mining Institute 7 (1901): 44-50.

Copper: From Mine to Finished Product. New York: Anaconda Copper Mining Company, 1920.

Costagliola, Pilario, Marco Benvenuti, Laura Chiarantini, Sara Bianchi, Francesco Di Benedetto, Mario Paolieri, and Luca Rossato. "Impact of Ancient Metal Smelting on Arsenic Pollution in the Pecora River Valley, Southern Tuscany, Italy." Applied Geochemistry 23, no. 5 (2008): 1241-59.

Craddock, Paul T. "The Composition of Copper Alloys Used by the Greek, Etruscan, and Roman Civilizations. 2. The Archaic, Classical and Hellenistic Greeks." Journal of Archaeological Science 4 (1977): 103-33.

—. "The Composition of Copper Alloys Used by the Greek, Etruscan, and Roman Civilizations. 3. The Origins and Early Use of Brass." Journal of Archaeological Science 5 (1978): 1-16. 
—. "The Composition of the Copper Alloys Used by the Greek, Etruscan, and Roman Civilizations. 1. The Greeks before the Archaic Period." Journal of Archaeological Science 3 (1976): 93-113.

- Early Metal Mining and Production Washington, D.C.: Smithsonian Institution Press, 1995.

Cravens, Curtis Copper on the Creek: Reclaiming an Industrial History. New York: Place in History, 2000.

Cronon, William. Changes in the Land: Indians, Colonists, and the Ecology of New England. New York: Hill and Wang, 1983.

_. "Kennecott Journey: The Paths out of Town." In Under an Open Sky: Rethinking America's Western Past, 28-51. New York: W. W. Norton and Company, 1992.

-Nature's Metropolis : Chicago and the Great West. William Cronon, ed. New York: W.W. Norton, 1991.

Cruikshank, Ken, and Nancy B. Bouchier. "Blighted Areas and Obnoxious Industries; Constructing Environmental Inequality on an Industrial Waterfront, Hamilton, Ontario, 1890-1960." Environmental History 9, no. 3 (2007): 30.

Culver, William W., and Cornel J. Reinhart. "Capitalist Dreams: Chile's Response to Nineteenth-Century World Copper Competition." Comparative Studies in Society and History 31, no. 4 (1989): 722-44.

Curtis, Kent. "Greening Anaconda." In Beyond the Ruins: The Meanings of Deindustrialization, edited by Jefferson Cowie and Joseph Heathcott, 91-111. Ithaca, New York: Cornell University Press, 2003.

Cushing, Frank Hamilton. "Primitive Copper Working: An Experimental Study." American Anthropologist 7, no. 1 (1894): 93-117.

Daniels, Karen. Tennessee's Historic Copper Basin Area: An Overview. Benton, Tenn.: Polk County Publishing, 1992.

Darwin, Charles. Journal of Researches into the Natural History and Geology of the Countries Visited During the Voyage Round the World of H.M.S. Beagle. Eleventh Edition, reprinted ed. London: John Murray, Albemarle Street, 1913.

Davis, J. R. ASM Specialty Handbook: Copper and Copper Alloys. Materials Park, 
Ohio: ASM International, 2001.

Davis Jr, R. A., A. T. Welty, J. Borrego, J. A. Morales, J. G. Pendon, and J. G. Ryan. "Rio Tinto Estuary (Spain): 5000 Years of Pollution." Environmental Geology 39, no. 10 (2000): 1107-1116.

Day, Joan, and R. F. Tylecote. The Industrial Revolution in Metals. London: The Institute of Metals, 1991.

Dayton, J. E. "The Problem of Tin in the Ancient World." World Archaeology 3, no. 1 (1971): 49-70.

"Detroit and Waterbury Copper Smelting Works." The Mining Magazine 1 (1853): 298.

Dobb, Edwin. "Pennies from Hell." Harper's Magazine October 1996 (1996): 39-54.

Donald. Maxwell, Bruce. Elizabethan Copper : The History of the Company of Mines Royal 1568-1605. London: Pergamon Press, 1955.

Egleston, N.H. "Copper Refining in the United States." Transactions of the American Institute of Mining Engineers 9 (1881): 678-730.

Egleston, T. "The Point Shirley Works." School of Mines Quarterly 7 (1886): 360-84.

Ek, Anna S., Stefan Lofgren, Johan Bergholm, and Ulf Qvarfort. "Environmental Effects of One Thousand Years of Copper Production at Falun, Central Sweden." Ambio 30, no. 2 (2001): 96-103.

Emmons, David M. "The Price of 'Freedom': Montana in the Late and Post-Anaconda Era." Montana: The Magazine of Western History 44, no. 4 (1994): 66-73.

Fairlie, Andrew Miller. Sulfuric Acid Manufacture. New York,: Reinhold Pub. Corp., 1936.

Farmer, Silas. The History of Detroit and Michigan; or, the Metropolis Illustrated; a Full Record of Territorial Days in Michigan, and the Annals of Wayne County. 2d ed. Detroit: S. Farmer \& Co., 1889.

Finn, Janet L. Tracing the Veins : Of Copper, Culture, and Community from Butte to Chuquicamata. Berkeley: University of California Press, 1998.

Francaviglia, Richard V. Hard Places : Reading the Landscape of America's Historic Mining Districts. The American Land and Life Series. Iowa City: University of 
Iowa Press, 1991.

Gabb, Gerald. Lower Swansea Valley Factsheet 7: The Rise and Fall of the Copper Industry. Swansea: Swansea Museum's Service, 1990 (est.)

Gates, William Bryam. Michigan Copper and Boston Dollars: An Economic History of the Michigan Copper Mining Industry. Cambridge: Harvard University Press, 1951.

Gillispie, Charles C., ed. Diderot Pictorial Encyclopedia of Trades and Industry: Manufacturing and the Technical Arts in Plates, Selected from L'encyclopédie; Ou, Dictionnaire Raisonné Des Sciences, Des Arts Et Des Métiers, of Denis Diderot. New York: Dover Publications, 1959.

Gladstone, J. H. "On the Transition from the Use of Copper to That of Bronze." The Journal of the Anthropological Institute of Great Britain and Ireland 26 (1897): 309-320.

Goin, Peter, and Elizabeth Raymond. "Living in Anthracite: Mining Landscape and Sense of Place in Wyoming Valley, Pennsylvania." The Public Historian 23, no. 2 (2001): 29-45.

Gordon, Robert B., and Patrick M. Malone. The Texture of Industry : An Archaeological View of the Industrialization of North America. New York: Oxford University Press, 1994.

Gorman, Hugh. "Manufacturing Brownfields: The Case of Neville Island, Pennsylvania." Technology and Culture 38, no. 3 (1997): 36.

Gowland, W. "Copper and Its Alloys in Early Times." Journal of the Institute of Metals 7 (1912): 23-49.

Gowland, William. "The Metals in Antiquity." Journal of the Royal Anthropological Institute of Great Britain and Ireland 42 (1912): 235-287.

Gowland, W. "Presidential Address: Copper and Its Alloys in Prehistoric Times." The Journal of the Anthropological Institute of Great Britain and Ireland 36, no. JanJune (1906): 11-38.

Grattan, J. P., D. D. Gilbertson, and C. O. Hunt. "The Local and Global Dimensions of Metalliferous Pollution Derived from a Reconstruction of an Eight Thousand Year Record of Copper Smelting and Mining at a Desert-Mountain Frontier in Southern Jordan." Journal of Archaeological Science 34, no. 1 (2007): 83-110. 
Grattan, J. P., G. K. Gillmore, D. D. Gilbertson, F. B. Pyatt, C. O. Hunt, S. J. McLaren, P. S. Phillips, and A. Denman. "Radon and 'King Solomon's Miners': Faynan Orefield, Jordanian Desert." Science of The Total Environment 319, no. 13 (2004): 99-113.

Greenberg, Peter. Don't Go There! : The Travel Detective's Essential Guide to the Must-Miss Places of the World. Emmaus, Pa.: Rodale, 2009.

Greenwood, William Henry. A Manual of Metallurgy. New York: G. P. Putnam's Sons, 1875.

Griffiths, Ralph A. The City of Swansea: Challenges and Change. Phoenix Mill, UK: Alan Stutton, 1990.

Hall, B. Clarence, and C. T. Wood. The South. New York: Scribner, 1995.

Hammersley, G. "The Effect of Technical Change in the British Copper Industry between the Sixteenth and Eighteenth Centuries." Journal of European Economic History 20 (1991): 155-73.

—_. "Technique or Economy; the Rise and Decline of the Early English Copper Industry." Business History 15, no. 1 (1973): 1-31.

Hardesty, Donald. "Issues in Preserving Toxic Wastes as Heritage Sites." The Public Historian 23, no. 2 (2001): 19-28.

Harris, J. R. "Copper and Shipping in the Eighteenth Century." Economic History Review 19, no. 3 (1966): 550-68.

Hedgcock, George Grant. "Injury by Smelter Smoke in Southwestern Tennessee." Journal of the Washington Academy of Sciences 4, no. 4 (1914): 70-71.

Herbert, Eugenia W. Red Gold of Africa: Copper in Pre-colonial History and Culture. Madison: University of Wisconsin, 1984.

Hofman, H. O. Metallurgy of Copper. New York: McGraw-Hill, 1924.

Hong, S., J. P. Candelone, C. C. Patterson, and C. F. Boutron. "History of Ancient Copper Smelting Pollution During Roman and Medieval Times Recorded in Greenland Ice." Science 272, no. 5259 (1996): 246-49.

Hong, S., J. P. Candelone, M. Soutif, and C. F. Boutron. "A Reconstruction of Changes in Copper Production and Copper Emissions to the Atmosphere During the Past 7000 Years." The Science of the total environment 188, no. 2-3 (1996): 
$183-95$.

Hong, Sungmin, Jean-Pierre Candelone, Clair C. Patterson, and Claude F. Boutron. "Greenland Ice Evidence of Hemispheric Lead Pollution Two Millennia Ago by Greek and Roman Civilizations." Science 265, no. 5180 (1994): 1841-43.

Howard, Peter. Heritage : Management, Interpretation, Identity. London ; New York: Continuum, 2003.

Hughes, Stephen. Copperopolis : Landscapes of the Early Industrial Period in Swansea. Aberystwyth, Ceredigion: Royal Commission on the Ancient and Historical Monuments of Wales, 2000.

Hunt, Chris O., David D. Gilbertson, and Hwedi A. El-Rishi. "An 8000-Year History of Landscape, Climate, and Copper Exploitation in the Middle East: The Wadi Faynan and the Wadi Dana National Reserve in Southern Jordan." Journal of Archaeological Science 34, no. 8 (2007): 1306-38.

Hyde, Charles K. Copper for America: The United States Copper Industry from Colonial Times to the 1990s. Tucson: University of Arizona Press, 1998.

Jenkins, R. "Copper Smelting in England: Revival at the End of the Seventeenth Century." Transactions of the Newcomen Society 24 (1943): 73-80.

_. "The Reverberatory Furnace with Coal Fuel." Transactions of the Newcomen Society 14 (1934): 67-81.

Johnson, Edward A. "Industrial Destruction Reversed at Copper Basin." National Woodlands 25, no. 2 (2002): 10-13, 29.

King, Thomas. Cultural Resource Laws and Practice. Walnut Creek, CA: Altamira Press, 2008.

Kuzell, Charles. "The Development of Modern Copper Smelting." Transactions of the Metallurgical Society of AIME 218, no. August (1960): 578-84.

Laist, Frederick. "Seventy-Five Years of Progress in Smelting and Leaching of Ores." In Seventy-Five Years of Progress in the Mineral Industry, 1871-1946, 126-61. New York: The American Institute of Mining and Metallurgical Engineers, 1948.

Lankton, Larry. Cradle to Grave: Life, Work, and Death at the Lake Superior Copper Mines. New York: Oxford University Press, 1991.

Lankton, Larry D. Beyond the Boundaries: Life and Landscape at the Lake Superior 
Copper Mines, 1840-1875. New York: Oxford University Press, 1997.

. Hallowed Ground: Copper Mining and Community Building on Lake

Superior, 1840s-1990s (Draft Version). Detroit: Wayne State University Press, 2010 (expected).

Lankton, Larry D., and Charles K. Hyde. Old Reliable : An Illustrated History of the Quincy Mining Company. Hancock, Mich.: Quincy Mine Hoist Association, 1982.

Leitner, Jonathan. "The 1869 Copper Tariff: The Politics and Geography of U.S. Development in World-Systems Perspective." Sociological Perspectives 43, no. 3 (2000): 437-97.

. "Red Metal in the Age of Capital: The Political Ecology of Copper in the Nineteenth-Century World-Economy." Review-Fernand Braudel Center for the Study of Economies, Historical Systems, and Civilizations 24, no. 3 (2001): 373439.

Lock, Alfred G., and Charles G. Lock. A Practical Treatise on the Manufacture of Sulphuric Acid. London: Sampson, Low, Marston, Searle, and Rivington, 1879.

Lovell, Endicott R., and Herman C. Kenny. "Present Smelting Practice." Mining Congress Journal 17 (1931): 533-38.

Lowenthal, David. The Heritage Crusade and the Spoils of History. Cambridge, U.K. ; New York: Cambridge University Press, 1998. 1985.

Lyman, Taylor. Metals Handbook. Novelty, Ohio: American Society for Metals, 1961.

Lynch, Martin. Mining in World History. London: Reaktion, 2002.

Makra, L., and P. Brimblecombe. "Selections from the History of Environmental Pollution, with Special Attention to Air Pollution. Part 1." International Journal of Environment and Pollution 22, no. 6 (2004): 641-656.

Malone, Michael P. "The Close of the Copper Century." Montana: The Magazine of Western History 35, no. 2 (1985): 69-72.

Malone, Michael P., Richard B. Roeder, and William L. Lang. Montana : A History of Two Centuries. Rev. ed. Seattle: University of Washington Press, 1991. 
Manasse, Andreal, and Marcello Mellini. "Chemical and Textural Characterisation of Medieval Slags from the Massa Marittima Smelting Sites (Tuscany, Italy)." Journal of Cultural Heritage 3, no. 2002 (2002): 187-206.

Marcosson, Isaac Frederick. Copper Heritage; the Story of Revere Copper and Brass Incorporated. New York: Dodd, Mead, 1955.

Marcus, Jerrold J. "Butte: Richest Hill on Earth and Costliest Mine Superfund Site." Engineering and Mining Journal 201, no. 2 (2000): 31-44.

Martin, Susan R. Wonderful Power: The Story of Ancient Copper Working in the Lake Superior Basin. Detroit: Wayne State University Press, 1999.

Mattson, Margaret E., and Tee L. Guidotti. "Health Risks Associated with Residence near a Primary Copper Smelter: A Preliminary Report." American Journal of Industrial Medicine 1 (1980): 365-74.

Melosi, Martin V., and Philip eds Scarpino. Public History and the Environment. Malabar, Florida: Krieger Publishing Company, 2004.

Mercier, Laurie. Anaconda: Labor, Community, and Culture in Montana's Smelter City. Urbana: University of Illinois Press, 2001.

Miskimin, Harry A. The Economy of Later Renaissance Europe. Cambridge: Cambridge University Press, 1977.

Morag-Levine, Noga. Chasing the Wind: Regulating Air Pollution in the Common Law State. Princeton, N.J.: Princeton University Press, 2003.

Morral, F. R. "A Mini-History of the Rio Tinto (Spain) Region." CIM Bulletin 83, no. 935 (1990): 5.

Napier, James. "On Copper Smelting." The Philosophical Magazine and Journal of Science 4 (1852): Non-consecutive pages, 45-59, 192-201, 62-71, 345-55, 453-65.

_. "On Copper Smelting." The Philosophical Magazine and Journal of Science 5 (1853): Non-consecutive pages, 30-39, 175-84, 345-54, 486-93.

Newell, Edmund. "Atmospheric Pollution and the British Copper Industry, 16901920." Technology and Culture 38, no. 3 (1997): 655-89.

\footnotetext{
District." Business History 32, no. 3 (1990): 75-97.
} 
Newell, Edmund, and Simon Watts. "The Environmental Impact of Industrialization in South Wales in the Nineteenth Century: 'Copper Smoke' and the Llanell." Environment and History 2, no. 3 (1996): 309-36.

Nriagu, Jerome O. Copper in the Environment. New York: Wiley, 1979.

. "Global Metal Pollution: Poisoning the Biosphere." Environment 32, no. 7 (1990): 7-33.

—. Lead and Lead Poisoning in Antiquity. New York: Wiley, 1983.

Olson, James M. Michigan Environmental Law: A Guide to Environmental Law. Traverse City, Michigan: Neahtawanta Press, 1981.

O'Neill, Hugh. "The Inventions of Bessemer in Relation to Non-Ferrous Metals." Metallurgia 54, no. 326 (1956): 269-73.

Ortega, Luis. "The First Four Decades of the Chilean Coal Mining Industry, 18401879." Journal of Latin American Studies 14, no. 1 (1982): 1-32.

Patterson, Clair C. "Native Copper, Silver, and Gold Accessible to Early Metallurgists." American Antiquity 36, no. 3 (1971): 286-321.

Percy, John. Metallurgy. The Art of Extracting Metals from Their Ores. London: J. Murray, 1861.

Peters, Edward Dyer. Modern Copper Smelting. New York: The Scientific Publishing Co., 1898.

Pettengill, Robert B. "The United States Foreign Trade in Copper." American Economic Review 25, no. 3 (1935): 426-41.

Piggot, A. Snowden. The Chemistry and Metallurgy of Copper, Including a Description of the Principal Copper Mines of the United States and Other Countries, the Art of Mining and Preparing Ores for Market, and the Various Processes of Copper Smelting. Philadelphia: Lindsay \& Blakiston, 1858.

Prain, Ronald. Copper: The Anatomy of an Industry. London: Mining Journal Books, 1975.

Price, Jon. "Interpreting Industrial Heritage." In Heritage Interpretation, edited by Allison Helms and Marion Blockley. New York: Routledge, 2006: 111-122. 
Przeworski, Joanne Fox. The Decline of the Copper Industry in Chile and the Entrance of North American Capital: 1870-1916. New York: Arno Press, 1980.

Pursell, Carrol. "The Rise and Fall of the Appropriate Technology Movement in the United States, 1965-1985." Technology and culture 34, no. 3 (1993): 629-37.

Pyatt, F. B. "Copper and Lead Bioaccumulation by Acacia Retinoides and Eucalyptus Torquata in Sites Contaminated as a Consequence of Extensive Ancient Mining Activities in Cyprus." Ecotoxicology and Environmental Safety 50, no. 1 (2001): 60-64.

Pyatt, F. B., G. W. Barker, P. Birch, D. D. Gilbertson, J. P. Grattan, and D. J. Mattingly. "King Solomon's Miners-Starvation and Bioaccumulation? An Environmental Archaeological Investigation in Southern Jordan." Ecotoxicology and Environmental Safety 43, no. 3 (1999): 305-08.

Pyatt, F. B., G. Gilmore, J. P. Grattan, C. O. Hunt, and S. McLaren. "An Imperial Legacy? An Exploration of the Environmental Impact of Ancient Metal Mining and Smelting in Southern Jordan." Journal of Archaeological Science 27, no. 9 (2000): 771-78.

Pyatt, F. B., and J. P. Grattan. "Some Consequences of Ancient Mining Activities on the Health of Ancient and Modern Human Populations." Journal of Public Health 23, no. 3 (2001): 235-236.

Pyatt, F. B., A. J. Pyatt, C. Walker, T. Sheen, and J. P. Grattan. "The Heavy Metal Content of Skeletons from an Ancient Metalliferous Polluted Area in Southern Jordan with Particular Reference to Bioaccumulation and Human Health." Ecotoxicology and Environmental Safety 60, no. 3 (2005): 295-300.

Quinn, M. -L. "The Appalachian Mountains' Copper Basin and the Concept of Environmental Susceptibility." Environmental Management 15, no. 2 (1991): 179-94.

_ . "Early Smelter Sites: A Neglected Chapter in the History of and Geography of Acid Rain in the United States." Atmospheric Environment 23, no. 6 (1989): $1281-92$.

__. "Industry and Environment in the Appalachian Copper Basin, 1890-1930." Technology and Culture 34, no. 3 (1993): 575-612.

—_. "Should All Degraded Landscapes Be Restored? A Look at the Appalachian Copper Basin." Land Degradation \& Rehabilitation 3 (1992): 115-134. 
Quivik, Fredric L. "The Anaconda Company Smelters: Great Falls and Anaconda." The Speculator 1, no. 2 (1984): 38-45.

_. "Integrating the Preservation of Cultural Resources with Remediation of Hazardous Materials: An Assessment of Superfund's Record." The Public Historian 23, no. 2 (2001): 47-61.

__ . "Landscapes as Industrial Artifacts: Lessons from Environmental History." IA: The Journal of the Society for Industrial Archeology 26, no. 2 (2000): 55-64.

— . "Of Tailings, Superfund Litigation, and Historians as Experts: U.S. V. ARCO, Et Al. (the Bunker Hill Case in Idaho)." The Public Historian 26, no. 1 (2004): 81-104.

Raymond, Robert. Out of the Fiery Furnace: The Impact of Metals on the History of Mankind. University Park: Pennsylvania State University Press, 1986.

Rehren, Thilo. "Small Size, Large Scale Roman Brass Production in Germania Inferior." Journal of Archaeological Science 26, no. 8 (1999): 1083-87.

Richter, F. E. "The Copper-Mining Industry in the United States, 1845-1925." Quarterly Journal of Economics 41, no. 2 (1927): 236-91.

Robertson, David. "Heaps of History: Toluca and the Historic Longwall Mining District." Journal of Illinois History 3, Autumn (2000): 162-84.

Rothenberg, Benno, H. G. Bachmann, and Studies Institute for ArchaeoMetallurgical. The Ancient Metallurgy of Copper : Archaeology-ExperimentTheory, Metal in History 3. London: Institute for Archaeo-Metallurgical Studies, 1990.

Scheinberg, I. Herbert. "Human Health Effects of Copper." In Copper in the Environment, edited by Jerome O. Nriagu, 17-33. New York: John Wiley and Sons, 1979.

Schmitz, Christopher J. World Non-Ferrous Metal Production and Prices 1700 1976. London: Frank Cass, 1979.

Schnabel, Carl. Handbook of Metallurgy. New York: Macmillan, 1898.

Seigworth, Kenneth J. "Ducktown-a Postwar Challenge: Can Man Correct a Century of Land Abuse in Tennessee's Copper Basin? A Start Has Been Made." American Forests 49, no. November (1943): 521-23, 58. 
Shaler, Nathaniel Southgate. Man and the Earth. New York: Fox, Duffield \& company, 1905.

Shapiro, Aaron. "Air Conditioned by the Cool Breezes of Lake Superior: Vacationing in Michigan's Copper Country." In New Perspectives on Michigan's Copper Country, edited by Alison K. Hoagland, Erik C. Nordberg and Terry S. Reynolds, 135-153. Hancock, Mich.: Quincy Mine Hoist Association, 2007.

Shovers, Brian. "Remaking the Wide-Open Town: Butte at the End of the Twentieth Century." Montana: The Magazine of Western History 48, no. 3 (1998): 40-53.

Shovers, Brian, Mark Fiege, Dale Martin, and Fred Quivik. Butte \& Anaconda Revisited: An Overview of Early-Day Mining and Smelting in Montana. Special Publication 99. Butte, Mont.: Montana Bureau of Mines and Geology; Montana College of Mineral Science and Technology, 1991.

Slack, Jennifer Daryl. "The Politics of the Pristine." Topia 2 (1998): 24.

Smith, Duane A. Mining America: The Industry and the Environment. 1800-1980. Lawrence, Kan.: University of Kansas Press, 1987.

Smith, Pamela H., and Paula Findlen. Merchants \& Marvels: Commerce, Science, and Art in Early Modern Europe. New York: Routledge, 2002.

St. Clair, Jeffery. "Something About Butte." In Red State Rebels: Tales of Grassroots Resistance in the Heartland edited by Joshua Frank and Jeffery St. Clair, 90-102. Oakland, California: AK Press, 2008.

Stevens, Horace J. The Copper Handbook. Vol. 10. Houghton, Mich.: Horace J. Stevens, 1911.

Sticht, Robert (Contributing Author). "Pyritic Smelting-Its History, Principals, Scope, Apparatus, and Practical Results." In Modern Copper Smelting, edited by Edward Dyer Peters, 396-441. New York: The Scientific Publishing, Co., 1898.

Stine, Jeffery K., and A. Tarr Joel. "At the Intersection of Histories: Technology and the Environment." Technology and Culture 39, no. 4 (1998): 601-640.

Strom, H. C. "Parallel between the British and the Continental Methods of Copper Smelting." The Mining Review 7, no. July (1835): 66-13.

Swansea, City and County of. A Short History of the Hafod Works: Swansea, Wales: Welsh Assembly Government, 2007. 
Theophilus. On Divers Arts; the Treatise of Theophilus. Translated by John G. Hawthorne and Cyril Stanley Smith. Dover Publications, Inc. (1979 reprint ed.) Chicago: University of Chicago Press, 1963.

Tidball, Eugene C. "What Ever Happened to the Anaconda Company?" Montana: The Magazine of Western History 47, no. 2 (1997): 60-68.

"Traveling Notes in South Wales." The Mirror of Literature, Amusement, and Instruction 17, no. 469 (1831): 1.

Toomey, Robert R. Vivian and Sons, 1809-1924: A Study of the Firm in the Copper and Related Industries, British Economic History. New York: Garland, 1985.

Tylecote, R. F. A History of Metallurgy. London: Institute of Metals, 1976.

—. A History of Metallurgy. Second ed: The Institute of Materials, 1992.

Ulke, Titus. "Notes on the History of Electrolytic Copper Refining in America." Electrochemical Industry 1, no. 7 (1902-3): 240.

Valenzuela, Luis "The Chilean Copper Smelting Industry in the Mid-Nineteenth Century: Phases of Expansion and Stagnation, 1834-58." Journal of Latin American Studies 24, no. 2 (1992): 507-50.

Vivian, John Henry. "An Account of the Process of Smelting Copper as Conducted at the Hafod Works, near Swansea." The Annals of Philosophy 5, no. January-June (1823): 113-24.

Wallace, Mike. Mickey Mouse History and Other Essays on American Memory. Philadelphia: Temple University Press, 1996.

Walters, Henry Beauchamp, and Samuel Birch. History of Ancient Pottery, Greek, Etruscan, and Roman. 2 vols. London: J. Murray, 1905.

Warren, Kenneth. Wealth, Waste, and Alienation: Growth and Decline in the Connellsville Coke Industry. Pittsburgh: University of Pittsburgh Press, 2001.

White, Richard. The Organic Machine. New York: Hill and Wang, 1995.

Wilson, Andrew. "Machines, Power, and the Ancient Economy." The Journal of Roman Studies 92 (2002): 1-31.

Wilson, Bob, Brennan Lang, and F. Brian Pyatt. "The Dispersion of Heavy Metals in the Vicinity of Britannia Mine, British Columbia, Canada." Ecotoxicology and 
Environmental Safety 60, no. 3 (2005): 269-76.

Wyckoff, William. "Postindustrial Butte." Geographical Review 85, no. 4 (1996): 18.

Young, Gordon, and Emory Kristoff. "The Tennessee Valley Today." National

Geographic 143, no. 6 (1973): 830-863.

Young, Otis E. "The American Copper Frontier, 1640-1893." The Speculator 1, no. 2 (1984): 4-15.

. "Origins of the American Copper Industry." Journal of the Early Republic 3, no. 2 (1983): 117-37.

\section{Legal Rulings, Cases, and Consent Decrees}

City and County of Butte-Silver Bow. (1985) "Council Bill No. 238, Ordinance 238

(Preservation Ordinance)," Butte, Mont.: Butte-Silver Bow.

Fields, T. (2001) "Memorandum of Understanding between Tennessee Department of Environment and Conservation, U.S. EPA and OXY, Inc.," CECRLA Docket No. 01-10-C, Atlanta, Geo.: U.S. EPA Region 4.

Hamilton, M. H. (2001) "Commissioner's Order," Site ID 70-510, Case No. 99-0480, Superfund. Nashville, Tenn.: State of Tennessee, Department of Environment and Conservation.

Hamilton, M. H. (2001) "North Potato Creek VOAP Order," Site ID 70-508, Case No. 99-0480, Superfund. Nashville, Tenn.: State of Tennessee, Department of Environment and Conservation.

Hankinson, J. H. (2001) "Administrative Order on Consent for Partial Payment," CERCLA Docket No. 01-13-C, edited by U.S. EPA. Atlanta, Geo.: U.S. EPA

Hankinson, J. H. (2001) "Administrative Order on Consent for Removal Action at the North Potato Creek Watershed," CERCLA Docket No. 01-11-C, edited by U.S. EPA. Atlanta, Geo.: U.S. EPA.

Hankinson, J. H. (2001) "Administrative Order on Consent for Removal Action at Davis Mill Creek Watershed," CERCLA Docket No. 01-12-C, edited by R. U.S. EPA. Atlanta, Geo.: U.S. EPA.

Supreme Court of Tennessee. (1903) "A.W. Swain v. Tennessee Copper Co. et al. and Thomas L. Cole v. Ducktown Sulphur, Copper \& Iron Co. Limited, et al.,", 
Knoxville, Tenn.: Supreme Court of Tennessee

United States Supreme Court. (1907) "State of Georgia v. Tennessee Copper Company and Ducktown Sulphur, Copper, \& Iron Company," Washington, D.C.: U.S. Supreme Court

United States Congress. (1966) "National Historic Preservation Act of 1966," Public Law 102-575. Washington D.C.: U.S. Congress

United States Environmental Protection Agency. (1990) "Agreement and Covenant Not to Sue (Boliden Intertrade)," Washington, D.C.: U.S. EPA.

United States District Court for the District of Montana. (1998) "State of Montana v. Atlantic Richfield Company, Consent Decree," Helena, Mont.: United States District Court.

United States District Court for the District of Montana. (1998) "United States v. Atlantic Richfield Company, State of Montana v. Atlantic Richfield Company, Streamside Tailings Operable Unit and Federal and Tribal Natural Resource Damages Consent Decree," Helena, Mont.: United States District Court.

\section{Newspaper Articles}

Chattanooga Sunday Times (Chattanooga, Tenn.)

Chattanooga Times Free Press (Chattanooga, Tenn.)

Cherokee Scout (Cherokee, NC)

Copper City Advance (Copperhill, Tenn.)

Daily Mining Gazette (Houghton, Mich.)

Detroit News (Detroit, Mich.)

Detroit Post and Tribune (Detroit, Mich.)

Great Falls Tribune (Great Falls, Mont.)

High Country News (Denver, Colo.)

Missoulian,(Missoula, Mont.)

Montana Eagle (Billings, Mont.)

Montana Standard (Butte, Mont.)

New York Times (New York, NY)

Spokesman Review (Spokane, Wash.)

Adams, Duncan. "Did Toxic Stew Cook the Goose?" High Country News, December 11, 1995. 
"Arcadian Mining Property Once the Rival of C\&H." Daily Mining Gazette, June 24, 1978.

"Browning Is Speaker Saturday at Conservation League Meet." Copper City Advance, May 25, 1950.

Chavez, Lynda. "When Arco Left Town." New York Times, July 25, 1982.

Clayton, Ron. "Ducktown Basin Museum Hits 30 with Plans to Keep Growing." Chattanooga Times Free Press, October 13, 2008.

Devlin, Sherry "Arco Recommends Leaving Milltown Sediment." Missoulian, November 6, 2001.

"The Detroit and Lake Superior Copper Co.'s Smelting Works." Detroit Post and Tribune Newspaper, 1879. In: Michigan Pioneer and Historical Collection 28 (1898): 647-652

Dixon, Chris. "Up from the Mines in Tennessee." New York Times, December 14, 2007.

"Editor of 1872 Writes About Ducktown Mines." Cherokee Scout, September 5, 1935.

Egan, Timothy. "In Its Own Decay, Butte Sees a National Treasure." New York Times, August 30, 1997.

"EPA Chief Says Closure a Surprise." The Montana Standard, October 1, 1980.

Haffey, Vera. "Anacondan's Remember Day the Smelter Closed." Montana Standard, September 29, 2005.

Haugland, Keith. "Stubborn Stack Dies Slowly." Great Falls Tribune, September 19, 1982.

Hauglie, Kurt. "\$1 Million Earmarked for Smelter." Daily Mining Gazette, June 27, 2009.

__. "EPA to Host Smelter Hearing." Daily Mining Gazette, January 12, 2009.

Lurgio, Jeremy. "Montanans Weigh Options on a Toxic Legacy." New York Times, May 7, 2001.

McCarthy, Bob. "Arco's Lethal Legacy." Montana Eagle 1981. 
—_. "Lethal Legacy, Part II." Montana Eagle, December 9, 1981.

Meets, Shari. "Anaconda Co. Closes Smelter." Montana Standard, September 30, 1980.

"'Must Conserve Resources If We Survive," - Browning." Copper City Advance, June 1, 1950.

Neese, Garrett. "Smelter Group Seeks Money from Council." Daily Mining Gazette, September 25, 2008.

Peters, Mouzon. "Healing the Scars in the Copper Basin." Chattanooga Sunday Times, September 2, 1956.

Robbins, Jim. "Butte Breaks Ground to Mop up a World-Class Mess." New York Times, July 21, 1998.

_ . "In a Town Called Opportunity, Distress over a Dump." New York Times, August 24, 2005.

—_. "Town Pins Hopes on Superfund Site." New York Times, April 6, 1997.

Steele, Karen Dorn. "Superfund Revived Butte." Spokesman Review, July 28, 2002.

van Sweringen, Hugh. "Shutdown Price Tag Will Be $\$ 40$ Million Annually." The Montana Standard, September 30, 1980.

Williams, Florence. "Butte, Montana, Seeks a New Life." High Country News, November 29, 1993.

"Wrought in Fire: Story of the Old Waterbury Copper Mill." Detroit News, March 29, 1896.

\section{Personal Communications}

Conversation with a Relevant Authority (1). Ducktown, Tenn. October 22, 2008.

Conversation with a Relevant Authority (2). Ducktown, Tenn. October 23, 2008.

Conversation with a Relevant Authority (3). Ducktown, Tenn. October 24, 2008.

Conversation with a Relevant Authority (4). Ducktown, Tenn. October 22, 2008. 
Conversation with a Relevant Authority (5). Butte, Mont. November 11, 2008.

Conversation with a Relevant Authority (6). Helena, Mont. November 17, 2008.

Conversation with a Relevant Authority (7). Butte, Mont. November 20, 2008.

Conversation with a Relevant Authority (8). Butte, Mont. November 11, 2008.

Conversation with a Relevant Authority (9). Butte, Mont. November 11, 2008.

Conversation with a Relevant Authority (10). Anaconda, Mont. November 17, 2008.

Conversation with a Relevant Authority (11). Anaconda, Mont. November 20, 2008.

\section{Reports and Government Documents}

"Assessing the Values of Cultural Heritage." edited by Marta De la Torre and Randall Mason. Los Angeles: Getty Conservation Institute, 2002.

"Butte, Montana: A Project Report." edited by Heritage Conservation and Recreation Service. Butte, Mont.: National Park Service, 1980.

"The Butte-Anaconda Historical Park System Master Plan." edited by Renewable Technologies Inc. Butte, Mont.: Butte Historical Society, 1985.

"Cities of Houghton and Hancock City Councils Joint Resolution on Restoration of the Quincy Smelter (May 30, 2007)." Houghton and Hancock, Mich.: Houghton and Hancock City Councils, 2007.

"Community Involvement Plan for the Copper Basin Mining District." edited by Community Involvement Partnership. Polk County, Tennessee: U.S. EPA, Tennessee Department for Environment and Conservation, and Glenn Springs Holdings, Inc., 2001.

"Copper Basin Mining District Case Study: Use of Cooperative Agreements toward a Common Goal." edited by U.S. EPA. Washington D.C.: U.S. EPA, 2005.

"Copper Basin Mining District Site Removal Action Update." edited by U.S. EPA Region 4. Atlanta, Geo.: U.S. EPA, 2007.

Daniels, Karen. "National Register of Historic Places Registration Form: Central Headframe." edited by National Park Service. Washington, D.C.: Department of 
the Interior, 1992.

. "National Register of Historic Places Registration Form: Copperhill Historic District." edited by National Park Service. Washington, D.C.: Department of the Interior, 1992.

. "National Register of Historic Places Registration Form: Ducktown Historic District." edited by National Park Service. Washington, D.C.: Department of the Interior, 1992.

_ _ "National Register of Historic Places, Multiple Property Documentation Form: Historic Resources of the Tennessee Copper Basin." edited by National Park Service. Washington, D.C.: Department of the Interior, 1992.

Davis, Christine E. "Archaeological Survey and Land-Use History of The Pittsburgh Technological Center Site, Pittsburgh, Pennsylvania." Pittsburgh: Urban Redevelopment Authority of Pittsburgh, 1989.

Dewey, Frederic P. "Bulletin of the United States National Museum, No. 42: A Preliminary Descriptive Catalogue of the Systematic Collections in Economic Geology and Metallurgy in the U. S. National Museum." Washington, D.C.: Smithsonian Institution, 1891.

"Declaration for the Record of Decision, Torch Lake Site, Michigan, Operable Units I and II." edited by U.S. EPA Region 5. Chicago: U.S. EPA, 1992.

Dosch, Donald F. "National Register of Historic Places Inventory - Nomination Form for Butte Historic District." edited by National Park Service. Washington, D.C.: U.S. Department of the Interior, 1972.

Emmons, David M. "United States District Court, District of Montana, Butte Division; United States of America v. Atlantic Richfield Company, et al; Expert Report of David Emmons, Ph.D.". Butte, Mont.: U.S. District Court, 1997.

"Engineering Report on Land Reclamation: Copper Basin - Polk County, Tennessee." edited by Cities Service Company. Copperhill, Tenn.: Cities Service Company, 1973.

"Engineering Report: Proposed Treatment Facilities, Copperhill Plants." edited by Cities Service Company. Copperhill, Tenn.: Cities Service Company, 1973.

"EPA Completes Construction at Torch Lake." edited by U.S. EPA Region 5. Chicago: U.S. EPA, 2006. 
"EPA Proposes Action on Davis Mill Creek." edited by U.S. EPA Region 4. Atlanta, Georgia: U.S. EPA, 2003.

"EPA Proposes Action on North Potato Creek." edited by U.S. EPA Region 4. Atlanta, Georgia: U.S. EPA, 2003.

"EPA Proposes Cleanup Plan for Quincy Smelter Erosion." edited by U.S. EPA Region 5. Chicago: U.S. EPA, 2008.

"EPA Record of Decision: Torch Lake OUs 1 \& 3 Houghton County, Michigan." edited by U.S. EPA Region 5. Chicago: U.S. EPA, 1992.

Fiege, Mark, Fredric L. Quivik, and Brian Shovers. "Industrial Heritage of Butte and Anaconda: An Analysis of the Historical Significance of the Surviving Physical Features of the Anaconda Copper Mining Company." Butte, Mont.: Butte Historical Society, 1985.

"Final General Management Plan and Environmental Impact Statement." edited by Keweenaw National Historical Park. Calumet, Michigan: U.S. Department of the Interior, 1998.

"Final Remedial Investigation Report, Operable Unit III." edited by Donohue and Associates. Chicago: U.S. EPA Region 5, 1992.

"Final Work Plan for Anaconda Smelter RI/FS." edited by CH2M Hill. Anaconda, Mont.: U.S. EPA, 1988.

"First Five-Year Review Report for the Torch Lake Superfund Site." edited by U.S. EPA Region 5. Chicago: U.S. EPA, 2003.

"A Future Use Plan for Redevelopment of the Abandoned Mine Lands in Copperhill Tennessee." edited by Waggoner Barge, Sumner, \& Cannon, Inc. Ducktown, Tenn.: Glenn Springs Holdings, Inc., 2003.

"General Work Plan, Anaconda Smelter NPL Site, Attachment I." Anaconda, Mont.: U.S. EPA Region 8, 1988.

"Historic and Archaeological Resource Protection for USEPA Personnel." edited by Office of Enforcement and Compliance Assurance. Washington, DC: U.S. EPA, 2007.

Hyde, Charles K. "Historic Report on the Quincy Mining Company." edited by National Park Service Washington, D.C.: Department of Interior, 1978. 
ICOMOS. "Evaluations of Cultural Properties." edited by Bureau of Cultural Properties World Heritage Convention: UNESCO, 2001.

Jackson, Charles T. "Geological and Mineralogical Report." Washington D.C.: United States Senate, 1849.

Lowenthal, David. "Stewarding the Past in a Perplexing Present." In Values and Heritage Conservation, edited by Erica Avrami, Randall Mason and Marta de la Torre, 18-32. Los Angeles: J. Paul Getty Trust, 2000.

Maher, Stuart W. "The Copper-Sulfuric Acid Industry in Tennessee." edited by Division of Geology, State of Tennessee Department of Conservation. Nashville, Tenn.: State of Tennessee, 1966.

Marion, Daniel P. "Final Screening Site Inspection Report, Tennessee Chemical Company." edited by Superfund Division NUS Corporation. Copperhill, Tenn.: U.S. EPA, Waste Management Division, 1989.

Martin, Dale, and Brian Shovers. "Butte, Montana: An Architectural and Historical Inventory of the National Landmark District." Butte, Mont.: Butte Historical Society, 1986.

Martin, Patrick. "Technical Report on the Archeological Survey of Isle Royal National Park." edited by Michigan Technological University. Houghton, MI: Isle Royale National Park, 1986.

Martin, Patrick, and Gianfranco Archimede. "The Quincy Mining Company Smelting Works, 1898: Historical Land Use Survey Project." edited by Michigan Technological University. Houghton, MI: Keweenaw National Historical Park, 2002.

"Minutes of the Meeting, May 26, 2005." edited by Butte-Silver Bow Local Government Study Commission. Butte, Mont.: Butte-Silver Bow Local Government, 2005.

Muncy, Jack A. "A Plan for Revegetation Completion of Tennessee's Copper Basin." edited by Division of Land and Economic Resources. Norris, Tenn.: Tennessee Valley Authority, 1986.

"National Register of Historic Places Registration Form: Butte-Anaconda Historic District-National Historic Landmark Nomination." edited by National Park Service. Butte, Mont.: U.S. Department of the Interior, 2005.

"Old Works Engineering Evaluation/Cost Analysis-Preliminary Site 
Characterization." edited by PTI Environmental. Bellevue, Wash.: ARCO, 1991.

"Old Works Operable Unit: Engineering Evaluation/Cost Analysis Work Plan." edited by U.S. Bureau of Reclamation. Billings, Mont.: U.S. EPA, 1988.

"Options for National Park Service Involvement in the Management of Historic Copper Mining Resources on Michigan's Keweenaw Peninsula." edited by National Park Service Midwest Region. Omaha, Nebraska: U.S. Department of Interior, 1988.

"Programmatic Agreement among the Environmental Protection Agency Region VIII Montana Office, the Advisory Council on Historic Preservation, the Montana State Historic Preservation Office, Montana Department of Health and Environmental Sciences, Local Governments of Butte/Silver Bow and Anaconda/Deer Lodge, Walkerville, and Arco Regarding Development of and Implementation of the Upper Clark Fork River Basin Regional Historic Preservation Plan." edited by U.S. EPA Region 8. Butte, Mont.: U.S. EPA, 1992.

"Programmatic Agreement among the Michigan State Historical Preservation Officer, Michigan Technological University and Keweenaw National Historical Park, National Park Service (U.S. Department of the Interior), Regarding the A.E. Seaman Mineralogical University Adaptive Reuse Project, Er06-107." edited by Michigan State Historic Preservation Office. Lansing, Mich.: MISHPO, 2006.

"Proposed Plan for Record of Decision Amendment for Operable Unit 3 at Torch Lake Superfund Site." edited by U.S. EPA Region 5. Chicago: U.S. EPA, 2008.

"Quincy Mining Company Annual Report for 1923." Hancock, Mich.: Quincy Mining Company, 1923.

"Record of Decision, Decision Summary, Torch Lake Sites, Operable Units I \& II, Houghton County Michigan." edited by U.S. EPA Region 5. Chicago: U.S. EPA, 1992.

"Regional Historic Preservation Plan: Butte-Anaconda Corridor." Butte, Mont.: Regional Historic Preservation Plan Joint Committee, 1993.

"Report for the Extent of Lead Contamination at the Former Isabella Lead Chamber Acid Plant, Ducktown, Tennessee." edited by Waggoner Barge, Sumner, \& Cannon, Inc. Nashville, Tenn.: Glenn Springs Holdings, Inc., 2003.

"Report of Inventory and Characterization of Former Mining and Processing Areas and Materials Located on Public and Private Lands." edited by Waggoner Barge, Sumner, \& Cannon, Inc. Ducktown, Tenn.: Glenn Springs Holdings, Inc., 2004. 
"Report of the Secretary of Agriculture for 1875." edited by U.S. Department of Agriculture. Washington, D.C.: U.S. D.A, 1875.

"Responsiveness Summary, Torch Lake Superfund Site, Operable Units I and II, Houghton County, Michigan." edited by U.S. EPA Region 5. Chicago: U.S. EPA, 1992.

"Role of Clean Air Act Requirements in Anaconda Copper Company's Closure of Its Montana Smelter and Refinery." edited by U.S. EPA Region 8. Denver, Colo.: U.S. EPA, 1981.

"Second Five-Year Review Report for Silver Bow Creek/Butte Area Superfund Site." edited by Camp Dresser and McKee. Helena, Mont.: U.S. EPA Region 8, 2005.

"Second Five-Year Review Report for the Torch Lake Superfund Site." edited by U.S. EPA Region 5. Chicago: U.S. EPA, 2008.

"Second Programmatic Agreement among the Environmental Protection Agency Region VII Montana Office, the Advisory Council on Historic Preservation, the Montana State Historic Preservation Office, Montana Department of Health and Environmental Sciences, Local Governments of Butte/Silver Bow and Anaconda/Deer Lodge, Walkerville, and Arco Regarding Development of and Implementation of the Upper Clark Fork River Basin Regional Historic Preservation Plan." edited by U.S. EPA Region 8. Butte, Mont.: U.S. EPA 1994.

Smith, Ralph I. "History of the Early Reduction Plants of Butte, Montana." Butte, Mont.: State of Montana Bureau of Mines and Geology: Montana College of Mines, 1953.

"Study of Alternatives for a Proposed Keweenaw National Historical Park." edited by National Park Service Midwest Region. Omaha, Neb.: National Park Service, 1991.

"Summary of 2008 Settlement of Clark Fork River Remediation and Natural Resources Damages Claims and Related Restoration Plans." edited by Natural Resource Damage Program. Helena, Mont.: Montana Department of Justice, 2008.

"Third Five-Year Review Report for Anaconda Company Smelter Site Anaconda, Deer Lodge County, Montana." edited by U.S. EPA Region 8. Helena, Mont.: U.S. EPA, 2005.

"Upper Clark Fork River Basin Restoration Plan Procedures and Criteria." edited by 
Natural Resource Damage Program. Helena, Mont.: State of Montana, 2000.

"Values and Heritage Conservation." edited by Erica Avrami, Randall Mason and Marta de la Torre. Los Angeles: Getty Conservation Institute, 2000.

\section{Theses and Dissertations}

Bridge, Gavin. "Regulating Nature: The Ecological Origins and Environmental Implications of Restructuring in the U.S. Copper Industry." PhD dissertation, Clark University, 1997.

Curran, Mary Elisabeth. "The Contested Terrain of Butte, Montana: Social Landscapes of Risk and Resiliency." Master's thesis, University of Montana, 1996.

Curtis, Kent. "An Ecology of Industry: Mining and Nature in Western Montana." $\mathrm{PhD}$ dissertation, University of Kansas, 2001.

Durali-Muller, Soodabeh. "Roman Lead and Copper Mining in Germany, Their Origin and Development Throughout Time Deduced from Lead and Copper Isotope Provenance Studies." PhD dissertation, Johann Wolfgang Goethe University 2005.

Jones, Michael Rice. "Oxhide Ingots, Copper Production, and the Mediterranean Trade in Copper and Other Materials in the Bronze Age." Master's thesis Texas A\&M, 2007.

LeCain, Timothy J. "Moving Mountains: Technology and the Environment in Western Copper Mining." PhD dissertation University of Delaware, 1998.

Quivik, Fred. "Smoke and Tailings: An Environmental History of Copper Smelting Technologies in Montana 1880-1930." PhD dissertation, University of Pennsylvania, History and Sociology of Science, 1998.

Van Lingen, Gary W. "The Interpretation of Archaeological Remains at the Pittsburgh and Boston Copper Harbor Copper Mining Company's Second Campsite: Evaluating a Structural Component and Its Potential Uses and Contexts." Master's thesis, Michigan Technological University, 2002. 


\section{Unpublished Manuscripts}

Bell, Peter, and Justin McCarthy. "Early Copper Smelting Technology in Australia." In Third International Mining History Conference. Golden Colorado, 1994. Conference Paper.

Borsos, E., L. Makra, R. Beczi, B. Vitanyi, and M. Szentpeteri. "Anthropogenic Air Pollution in Ancient Times." Universitatis Szegediensis, Szeged, Hungary: Universitatis Szegediensis, 2003. Conference Paper.

Brignola, Alessandra "The Michigan Smelter at Cole Creek, Houghton: An Introduction." Houghton, MI: Michigan Technological University, 2006. Unpublished graduate paper available at Michigan Technological University Archives.

Corless, James. "The Significance and Status of the Quincy Smelting Works, Franklin Township, Michigan (White Paper)." edited by Keweenaw National Historical Park. Calumet, Mich.: Keweenaw National Historical Park, 2008. Available at Keweenaw National Park.

"Dates in Basin History." Ducktown, TN: Ducktown Basin Museum, 2000 (est.). Available at Ducktown Basin museum.

"Dates in TCC and Copper Basin History." Copperhill, Tenn.: Tennessee Chemical Company, 1987. Available at Ducktown Basin museum.

"Letter from EPA Region 5 to Frank Fiala, National Park Service-U.S. Department of the Interior (June 23, 2004)." Available at Keweenaw National Park.

"Letter from EPA Region 5 to Mr. Jim Corless, Superintendant, Keweenaw National Park (January 20, 2009)." Available at Keweenaw National Park.

Nordberg, Erik C. "Quincy Mine Hoist Association Anniversary Banquet." Hancock, Michigan: Quincy Mine Hoist Association, 2008. Unpublished booklet available at Michigan Tech Archives.

Rush, Ken. "Copper Mining Companies of the Basin." Ducktown, Tenn.: Ducktown Basin Museum, 1993. Available at Ducktown Basin Museum.

Strong, Katherine. "Shoreline Change Along the Portage Canal." Houghton, Michigan: Michigan Technological University, 2002. Unpublished graduate paper available at Michigan Technological University Archives.

Trepal, Dan. "The Calumet \& Hecla Smelting Works: 1887-2006." Houghton, MI: 
Michigan Technological University, 2006. Unpublished graduate paper available at Michigan Technological University Archives.

"Copperama," 1960 (est.). Unpublished pamphlet available at Michigan Tech Archives

Wilson, C. P. "A Brief History of Copper Smelting on Portage Lake." Houghton, MI: Michigan Technological University, 2008. Unpublished graduate paper available at Michigan Technological University Archives.

\section{WebPages}

"A barren landscape was created after miners cut down forests for fuel. Location: Near Copperhill, Tennessee, (Picture Id: 620678.)" National Geographic Stock, 2008 (est.), www.nationalgeographicstock.com/ngsimages/explore, (accessed December 10 2008).

"Butte Silver Bow Public Archives." City and County of Butte-Silver Bow, 2009, www.buttearchives.org, (accessed May 2, 2009).

"CERCLA and NHPA Coordination for Superfund Sites." National Preservation Institute, 2009, www.npi.org/sem-cercla.html, (accessed July 11, 2009).

"CITGO Company History." CITGO Petroleum Company, 2009, www.citgo.com/aboutcitgo/companyhistory.jpg, (accessed March 4, 2009).

"Cleanup Process." Superfund-U.S. EPA, June 3, 2009, www.epa.gov/superfund/cleanup/index.htm, (accessed July 11, 2009.)

“Copper Basin.” Glenn Springs-Copper Basin Project, www.glennspringscopperbasinproject.com/history.htm, (accessed March 7, 2009).

"Copper Basin Mining District." U.S. EPA Region 4, February 18, 2009, www.epa.gov/region4/waste/copper, (accessed March 13, 2009).

“Copper Basin Reclamation Project.” Tennessee Valley Authority. 2003 (est.), www.tva.gov/environment/land/copper.htm, (accessed March 11, 2009).

"Copper Statistics." U.S. Geological Survey Historical Statistics for Mineral and Material Commodities in the United States, 2006, http://minerals.usgs.gov/ds/2005/140/copper/pdf, (accessed March 13, 2008).

“Copper Statistics and Information." USGS Minerals Information, June 15, 2009, 
http://minerals.usgs.gov/minerals/pubs/commodity/copper, (accessed July 8, 2009).

“County Population Census Counts 1900-90." U.S. Census Bureau, July 15, 2008, www.census.gov/population/www/censusdata/cencounts/index.html, (accessed April 4, 2009).

"Gold Statistics." U.S. Geological Survey Historical Statistics for Mineral and Material Commodities in the United States, 2006, http://minerals.usgs.gov/ds/2005/140/gold/pdf, (accessed 15 March, 2008).

"History of the Museum." World Museum of Mining, February 14, 2008, www.miningmuseum.org/historyofwmm.html, (accessed April 2, 2009)

"Keweenaw Heritage Sites." Keweenaw National Historical Park, April 3, 2008, www.nps.gov/kewe/parkmgmt/keweenaw-heritage-sites.htm, (accessed June 25, 2009).

"Material Property Data." MatWeb, 2008, www.matweb.com, (accessed March 13, 2008).

"Old Works/East Anaconda Smelter Case Study." Superfund-U.S. EPA. September 19, 2007, www.epa.gov/superfund/programs/recycle_old/success/ casestud/anaccsi.htm, (accessed September 20, 2008).

"Photograph and Image Search." Tennessee State Library and Archives, 2009, http://tnsos.org/tsla/imagesearch/index.php, (accessed March 31, 2009).

"Pig Iron Statistics." U.S. Geological Survey Historical Statistics for Mineral and Material Commodities in the United States, 2007, http://minerals.usgs.gov/ds/2005/140/ironsteel/pdf, (accessed March 13, 2008).

"Silver Statistics." U.S. Geological Survey Historical Statistics for Mineral and Material Commodities in the United States, 2006, http://minerals.usgs.gov/ds/2005/140/silver/pdf, (accessed 15 March, 2008).

"Southeast Tennessee Development District." Southeast Development Group, 2009, www.sedev.org, (accessed March 13, 2009).

"Superfund Program, Anaconda Co. Smelter Site." Superfund-U.S. EPA. 2009 (est.) www.epa.gov/unix 0008/superfund/mt/anaconda/index.html, (accessed July 8, 2009).

“Superfund Program: Anaconda Co. Smelter Site.” U.S. EPA Region 8, March 17, 
2009, www.epa.gov/region8/superfund/mt/anaconda/index.html, (accessed April $18,2009)$.

"Superfund Program: Silver Bow Creek/Butte Area." U.S. EPA Region 8, March 17, 2009, www.epa.gov/region8/superfund/mt/sbcbutte/index.html, (accessed April $18,2009)$.

"Tennessee Historical Commission State Owned Sites." Tennessee Department of Environment and Conservation, February 7, 2005, www.state.tn.us/environmental/hist/stateown/ducktown.shtml, (accessed March 12, 2009).

"USA State \& County Quickfacts." U.S. Census Bureau, February 20, 2009, http://quickfacts.census.gov, (accessed March 24, 2009).

"Welcome to Anaconda." Community of Anaconda, Montana, 2008, www.anacondamt.org, (accessed April 2, 2009).

"Who are we and how are we organized?" U.S. EPA, 2009, www.epa.gov/epahome/aboutepa.htm, (accessed July 11, 2009). 